Cover Photo: Stand of Port-Orford-cedar displaying a variety of age groups and levels of health on the South Fork of the Coquille River, Oregon 
QK
404.5

. 9975

R24

2003

\section{A Range-Wide Assessment of Port-Orford-Cedar (Chamaecyparis lawsoniana) on Federal Lands}




\title{
A Range-Wide Assessment of Port-Orford-Cedar \\ (Chamaecyparis lawsoniana) on Federal Lands
}

\author{
October 2003
}

\section{Edited by:}

Frank Betlejewski

Kirk C. Casavan

Angel Dawson

Donald J. Goheen

Kristi Mastrofini

Donald L. Rose

Diane E. White 


\section{Authors}

Peter A. Angwin is a plant pathologist, U.S. Department of Agriculture, Forest Service, Northern California Shared Service Area, Redding, California.

Thomas Atzet is the area ecologist, U.S. Department of Agriculture, Forest Service, Siskiyou National Forest, Grants Pass, Oregon.

Richard N. Barnes is a forestry consultant, Barnes and Associates, Roseburg, Oregon.

Frank Betlejewski is the Port-Orford-cedar program manager, U.S. Department of Agriculture, Forest Service, Southwest Oregon Forest Insect and Disease Service Center, Central Point, Oregon.

Kirk C. Casavan is the Port-Orford-cedar coordinator, U.S. Department of the Interior, Bureau of Land Management, Roseburg, Oregon.

Laura M. Chapman is the rural community assistance coordinator, U.S. Department of Agriculture, Forest Service, Six Rivers National Forest, Eureka, California.

Leslie J. Elliot is a forestry technician, U.S. Department of Agriculture, Forest Service, Umpqua National Forest, Dorena Genetic Resource Center, Cottage Grove, Oregon.

Donald J. Goheen is a plant pathologist/entomologist, U.S. Department of Agriculture, Forest Service, Southwest Oregon Forest Insect and Disease Service Center, Central Point, Oregon.

James E. Hamlin is the area geneticist, U.S. Department of Agriculture, Forest Service, Umpqua National Forest, Roseburg, Oregon.

Lisa D. Hoover is a botanist, U.S. Department of Agriculture, Forest Service, Six Rivers National Forest, Eureka, California.

Thomas M. Jimerson is an ecologist, U.S. Department of Agriculture, Forest Service, Six Rivers National Forest, Eureka, California.

Jay Kitzmiller is the regional geneticist, Pacific Southwest Region, U.S. Department of Agriculture, Forest Service, Chico, California.

John T. Kliejunas is the regional pathologist, U.S. Department of Agriculture, Forest Service, Pacific Southwest Region, Vallejo, California.

Claude C. McLean is a forestry consultant, Barnes and Associates, Roseburg, Oregon.

Kathy McClellan-Heffner is a tribal relations specialist, U.S. Department of Agriculture, Forest Service, Six Rivers National Forest, Eureka, California.

Elizabeth A. McGee is an ecologist, U.S. Department of Agriculture, Forest Service, Six Rivers National Forest, Eureka, California.

Michael G. McWilliams is a forest health monitoring specialist, Oregon Department of Forestry, Salem, Oregon. 
Christopher S. Park is a forest hydrologist, U.S. Department of Agriculture, Forest Service, Siskiyou National Forest, Grants Pass, Oregon.

Donald L. Rose is an environmental coordinator, Bonneville Power Administration, Portland, Oregon (formerly Port-Orford-cedar program manager, U.S. Department of Agriculture, Forest Service, Siskiyou National Forest, Grants Pass, Oregon).

Richard A. Sniezko is the center geneticist, U.S. Department of Agriculture, Forest Service Umpqua National Forest, Dorena Genetic Resource Center, Cottage Grove, Oregon.

Roderick D. Stevens is a geneticist, U.S. Department of the Interior, Bureau of Land Management, Roseburg District, Roseburg, Oregon.

Maria T. Ulloa is a forest botanist, U.S. Department of Agriculture, Forest Service, Siskiyou National Forest, Grants Pass, Oregon.

Diane E. White is an ecologist, U.S. Department of Agriculture, Forest Service, Rogue River National Forest, Medford, Oregon.

\section{Acknowledgements}

We would like to thank the following people who provided ideas and support for this document:

Allen Agnew, Andrew Bower, Jeffrey Jones, Erik Jules, Matthew Kaufmann, Debra Kroeger, Joseph Linn, Eric Martz, James Nielsen, Michael Martischang, Julie Nelson, Jodie Sharpe, Douglas Snider and Ralph Wagnitz, among others.

We would also like to give special thanks to Dr. Everett Hansen and Dr. Donald Zobel. Each provided ideas and support with their unique perspective. The quality of this document was substantially improved by their input.

Thank you to Torry Casavan and Patricia Martinez for the difficult task of word processing.

\section{Note Regarding Dates}

The completion date for all chapters other than Chapter Seven is June 2001.

The completion date for Chapter Seven is February 1999. 


\section{Table of Contents}

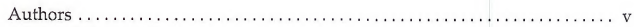

Acknowledgements ...................................... vi

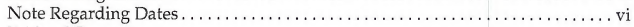

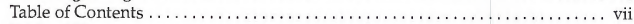

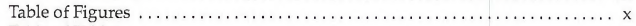

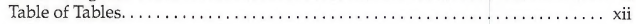

Executive Summary $\ldots \ldots \ldots \ldots \ldots \ldots \ldots \ldots \ldots \ldots \ldots \ldots \ldots \ldots \ldots \ldots \ldots \ldots \ldots \ldots \ldots \ldots \ldots$

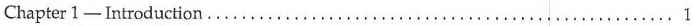

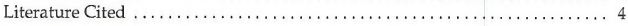

Chapter 2 - Ecological Factors Associated with Port-Orford-Cedar. . . . . . . . . . . . 5

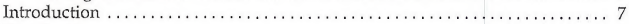

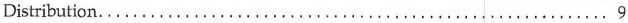

Ecoregion and Subsection Descriptions $\ldots \ldots \ldots \ldots \ldots \ldots \ldots \ldots \ldots \ldots \ldots \ldots$

Northern Coast. ............................... 10

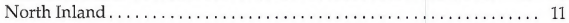

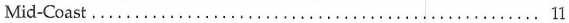

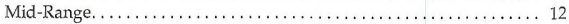

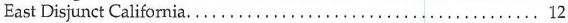

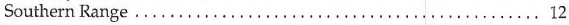

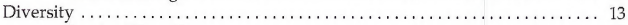

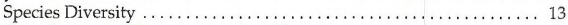

Plant Series and Plant Association Diversity ............... 13

Productivity Indices. . . . . . . . . . . . . . . . . . . . . . . . . . . 24

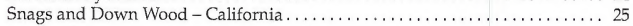

Snags ...................................... 25

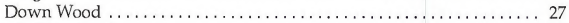

Function in Riparian Systems. . . . . . . . . . . . . . . . . . . 29

Port-Orford-Cedar Plant Associations with Unique Species and Regional

Endemic, Rare or Sensitive Plants . . . . . . . . . . . . . . . . . . . 30

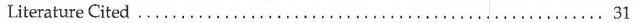

Chapter 3 - Phytophthora lateralis and Other Agents that Damage Port-Orford-Cedar . 33

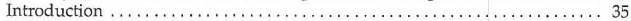

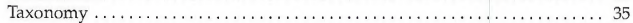

Life Cycle. ....................................... 35

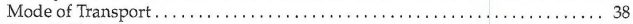

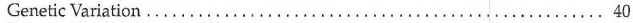

Disease Identification and Detection. . . . . . . . . . . . . . . . . . 41

Characteristics of Long-Term Infestation . . . . . . . . . . . . . . . . . 42

Additional Agents Affecting Port-Orford-Cedar. . . . . . . . . . . . . . 42

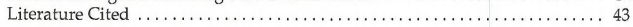

Chapter 4 - Impacts of Phytophthora lateralis on Port-Orford-Cedar. . . . . . . . . 47

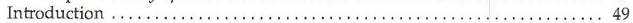

Extent of Infestation. . . . . . . . . . . . . . . . . . . . . . . 49

Geographic Information System Mapping Methodologies . . . . . . . . . . 51

Location by Land Allocation . ............................ 51

California Port-Orford-Cedar Plant Associations with More Than 10 percent

P. lateralis Infestation. . . . . . . . . . . . . . . . . . . . . . . . . 52

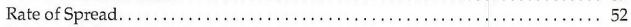

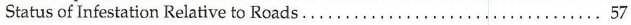


Landscape Level Impacts of Port-Orford-Cedar Root Disease . . . . . . . . . . 59

Coquille River Falls Research National Area . . . . . . . . . . . . 59

Powers Roads ................................... 59

Smith River Watershed $\ldots \ldots \ldots \ldots \ldots \ldots \ldots \ldots \ldots \ldots \ldots \ldots \ldots, 60$

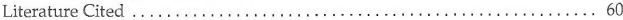

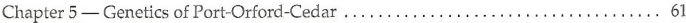

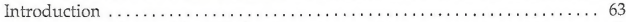

Importance of Genetic Resources $\ldots \ldots \ldots \ldots \ldots \ldots \ldots \ldots \ldots \ldots, 63$

Genetic Structure of a Species ........................ 63

Measurement of Genetic Structure: genetic tests ............. 64

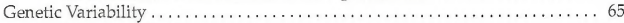

Allozyme Studies................................ 65

Common Garden Studies . . . . . . . . . . . . . . . . . . . . . . . . . 66

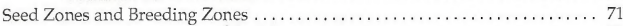

Port-Orford-Cedar Breeding Block Designations . . . . . . . . . . . . . 71

Implications for Genetic Conservation $\ldots \ldots \ldots \ldots \ldots \ldots \ldots \ldots \ldots \ldots, 73$

Literature Cited $\ldots \ldots \ldots \ldots \ldots \ldots \ldots \ldots \ldots \ldots \ldots \ldots \ldots \ldots \ldots \ldots \ldots \ldots \ldots$

Chapter 6 - Breeding For Resistance to Phytophthora lateralis $\ldots \ldots \ldots \ldots \ldots \ldots \ldots 75$

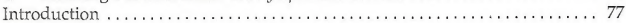

The Resistance Screening Process $\ldots \ldots \ldots \ldots \ldots \ldots \ldots \ldots \ldots \ldots \ldots, \ldots \ldots \ldots$

Resistance Screening Results . ............................ 81

Validation of the Screening Process. . . . . . . . . . . . . . . . . . . . . 82

Common Garden Study . . . . . . . . . . . . . . . . . . . . . . . . 83

Geographic Variation in Resistance Traits . . . . . . . . . . . . 83

Phenotypic Correlations Among Traits. ................... 84

Variation in Disease Resistance at the Watershed Level ........... 84

Variation in Disease Resistance at the Breeding Zone Level . . . . . . . 84

Breeding Program . .................................... 85

Controlled Pollination. ........................... 85

Vegetative Reproduction. ........................... 86

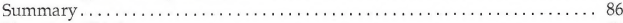

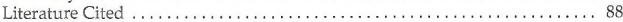

Chapter 7 - Economic Value of Port-Orford-Cedar................... 91

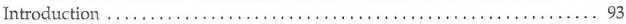

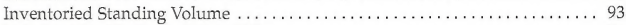

Effects of the Northwest Forest Plan . . . . . . . . . . . . . . . . . . 94

Export of Port-Orford-Cedar . . . . . . . . . . . . . . . . . . . . . . . 94

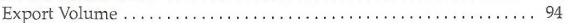

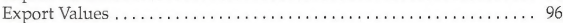

Domestic Use of Port-Orford-Cedar . . . . . . . . . . . . . . . . . . 97

Domestic Volume. . . . . . . . . . . . . . . . . . . . . . . . . . . . 98

Domestic Value. ................................ 98

Combined Export and Domestic Volume and Value ................ 98

Value Added Components ............................... 99

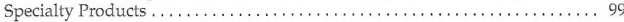

Arrow Shafts.................................. 99

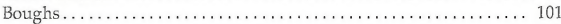

Employment........................................... 102

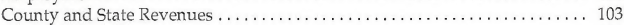

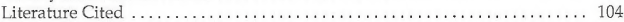

Chapter 8 - Social Value of Port-Orford-Cedar ..................... 105

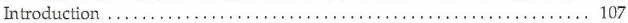

Native American Values ............................. 107 
Asian Values ...................................... 108

Local Values, Case Study 1: The Williams Port-Orford-Cedar Management Project 109

Background ...................................... 109

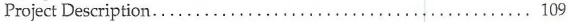

Late-Successional and Riparian Reserve Management .......... 109

Strategies................................... 110

Treatments...................................... 110

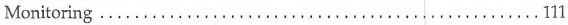

Reactions of Williams Residents ...................... 111

Landscape Approach to Managing Port-Orford-Cedar.......... 114

Local Values, Case Study 2: Managing Port-Orford-Cedar in High Plateau . . 114

Public Values and User Conflicts. . . . . . . . . . . . . . . . 115

Disease Management in the Smith River Basin and High Plateau. . . . 116

The Controversy Heats Up: The Six Rivers Forest Plan .......... 116

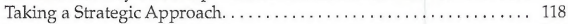

Special Interest Area (SIA) Management Strategy .............. 119

Assessing the Level of Risk to Port-Orford-Cedar in High Plateau . . . 120

Why Propose A Year-Round Closure? . . . . . . . . . . . . . . . . . 120

The Public Response . . . . . . . . . . . . . . . . . . . . . . 121

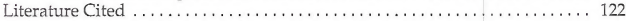

Chapter 9 - Methods of Assessing Risk. . . . . . . . . . . . . . . . . . . . 125

Components of Risk Assessment. . . . . . . . . . . . . . . . . . . . 127

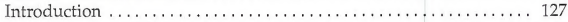

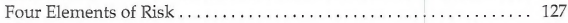

The Social Context of Risk ............................... 128

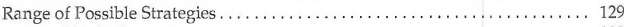

No-Action ................................... 129

Slow the Rate of Infection . . . . . . . . . . . . . . . . . . . . . 129

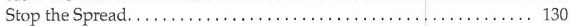

Eliminate $P$. lateralis .............................. 130

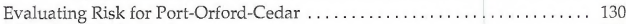

After the Risk Analysis . . . . . . . . . . . . . . . . . . . . . . 132

Quantification of Risk Factors . . . . . . . . . . . . . . . . . . . . 132

Literature Cited $\ldots \ldots \ldots \ldots \ldots \ldots \ldots \ldots \ldots \ldots \ldots \ldots \ldots \ldots \ldots \ldots \ldots$

Chapter 10 - Management Techniques and Challenges ................. 135

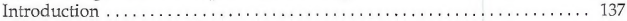

General Management Techniques ......................... 137

Operational Planning and Scheduling $\ldots \ldots \ldots \ldots \ldots \ldots \ldots \ldots \ldots \ldots$

Integrating Disease Treatments with Road Design, Engineering,

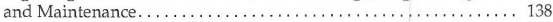

Water Source Selection and Treatment ................... 141

Regulating Non-Timber Uses......................... 141

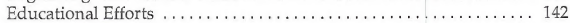

Prescribed Fire Potential ........................... 143

Genetic Resistance Breeding Development ................ 144

Specific Management Techniques . . . . . . . . . . . . . . . . . . . . 144

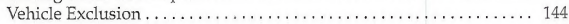

Temporary Road Closures $\ldots \ldots \ldots \ldots \ldots \ldots \ldots \ldots \ldots \ldots \ldots \ldots$

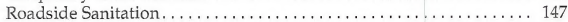

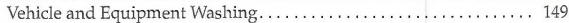

Case Studies ....................................... 152

Effectiveness Monitoring of Port-Orford-Cedar Roadside Sanitation

Treatments in Southwest Oregon .................... 152

Effectiveness of Vehicle Washing in Decreasing Transport of

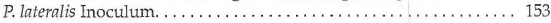


Managing Port-Orford-Cedar in Areas Not Favorable to the Pathogen . . . . . . 154

Managing Port-Orford-Cedar in Areas Favorable to the Pathogen ......... 155

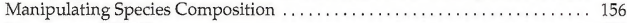

Management Challenges............................... 156

Difficulty of Monitoring Effectiveness of Management Activities ... 156

Few Opportunities to Obtain New Management-Related Research

Results............................... 156

Public Opposition to Agency Management Activities ........... 157

Coordination Difficulties .......................... 157

Funding Uncertainties. . . . . . . . . . . . . . . . . . . . . . 157

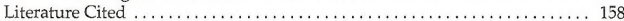

Appendix A

The Relationship of the Port-Orford-Cedar Range-wide Assessment to Other

Legal Documents and Authorities ........................ 161

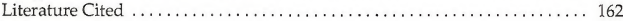

Appendix B

Occurrence of Plant Associations with Port-Orford-Cedar by Ecoregion or

Subsection........................................ 163

Appendix C

Unique Species and Regional Endemic, Rare or Sensitive Plants Found in

Ecology Plots Used for Classification of Port-Orford-Cedar and Species

Known to Occur with Port-Orford-Cedar. ....................... 169

Appendix D

Port-Orford-Cedar Short-term Raised Bed Common Garden Study Analysis

of Variance Tables and Means ........................... 171

Appendix E

Details of Resistance Screening Process . . . . . . . . . . . . . . . 175

Appendix F

Field Validation Plantings of Potentially Resistant Port-Orford-Cedar. . . . . 177

Appendix $G$

Development of the Interagency Port-Orford-Cedar Root Disease

Management Coordination Effort: A Brief History................

\section{Table of Figures}

Figure 1.1-Dense understory of Port-Orford-Cedar near Coos Bay, Oregon . . . . . . . 3

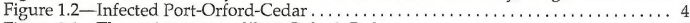

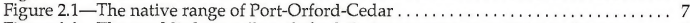

Figure 2.2-The world's largest Port-Orford-Cedar growing near Powers, Oregon ... . . 8

Figure 2.3-The world's largest Port-Orford-Cedar growing near Powers, Oregon ..... 8

Figure 2.4-Ecoregions and subsections with Port-Orford-Cedar occurrence ......... 10

Figure 2.5-The relationship of species commonly found in association with

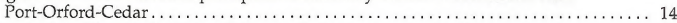

Figure 2.6 -The relationship of plant series to environmental factors . . . . . . . . . 14

Figure 2.7-Port-Orford-Cedar-White Fir/Herb plant association. . . . . . . . . . . 15

Figure 2.8-The Port-Orford-Cedar-Western White Pine/California Pitcher Plant

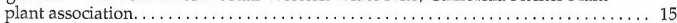

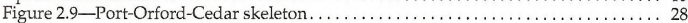

Figure 2.10-Down logs in a Port-Orford-Cedar stand .................... 29

Figure 2.11 -Port-Orford-Cedar in a riparian area $\ldots \ldots \ldots \ldots \ldots \ldots \ldots \ldots \ldots \ldots$

Figure 2.12 - Port-Orford-Cedar in Pipe Fork Research Natural Area (Williams

Watershed, Josephine County), the eastern-most extent of the species in Oregon . . . . 30

Figure 3.1 -Spore types of Phytophthora lateralis $\ldots \ldots \ldots \ldots \ldots \ldots \ldots \ldots \ldots \ldots \ldots$

Figure 3.2 - Phytophthora sporangia containing zoospores................ 37

Figure 3.3-Favorable conditions for spreading Phytophthora lateralis by vehicles ..... 38

Figure $3.4-$ Phytophthora lateralis infected root. . . . . . . . . . . . . . . . . . 39

Figure 3.5-Cambial stain on infected Port-Orford-Cedar. . . . . . . . . . . . . . . 41

Figure 4.1-Port-Orford-Cedar killed by Phytophthora lateralis ............... 49 
Figure 4.2-Healthy and infected Port-Orford-Cedar on federal lands. . . . . . . . 50

Figure 4.3-Phytophthora lateralis infestation, Smith River $1980 \ldots \ldots \ldots \ldots \ldots \ldots \ldots .53$

Figure 4.4-Phytophthora lateralis infestation, Smith River $1983 \ldots \ldots \ldots \ldots \ldots \ldots \ldots . \ldots 4$

Figure 4.5-Phytophthora lateralis infestation, Smith River $1993 \ldots \ldots \ldots \ldots \ldots \ldots \ldots$

Figure 4.6 - Phytophthora lateralis infestation, Smith River 1999 . . . . . . . . . . . 56

Figure 4.7-Condition of Port-Orford-Cedar in National Forests in California relative

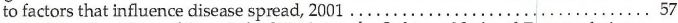

Figure 4.8-Condition of Port-Orford-Cedar in the Siskiyou National Forest relative

to factors that influence disease spread, $2001 \ldots \ldots \ldots \ldots \ldots \ldots \ldots \ldots \ldots \ldots . \ldots \ldots$

Figure 4.9- Condition of Port-Orford-Cedar in the Elk River Watershed, Siskiyou

National Forest, relative to factors that influence disease spread, 2001 . . . . . . . 59

Figure 5.1 -Port-Orford-Cedar branch bearing cones $\ldots \ldots \ldots \ldots \ldots \ldots \ldots \ldots \ldots \ldots$

Figure 5.2-Raised bed, short-term common garden study at the Humboldt Nursery

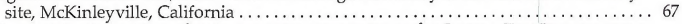

Figure 5.3-Raised bed, short-term common garden at the Dorena Tree Improvement

Center, Cottage Grove, Oregon . . . . . . . . . . . . . . . . . . . . . . . . 68

Figure 5.4-Long-term out-planting site at Weaverville-Trinity Lake, California ...... 70

Figure 5.5-Long-term out-planting site at Humboldt Nursery, McKinleyville,

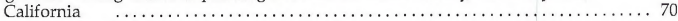

Figure 5.6 -Port-Orford-Cedar breeding blocks . . . . . . . . . . . . . . . . . 72

Figure 6.1-Resistant Port-Orford-Cedar trees growing with infected

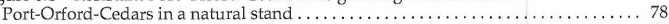

Figure 6.2 -Field selection and mapping of a Port-Orford-Cedar candidate tree . . . . 78

Figure 6.3 - Collecting branches for resistance screening. . . . . . . . . . . . . 79

Figure 6.4-Stem dip technique for inoculating samples for testing resistance to

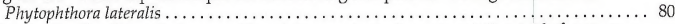

Figure 6.5-Seedlings being monitored for survival after inoculation with the root

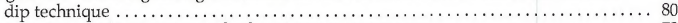

Figure 6.6 -Field plantings of high resistance genotypes $\ldots \ldots \ldots \ldots \ldots \ldots \ldots \ldots$

Figure 6.7-Pollen shed by Port-Orford-Cedar growing at Dorena Tree Improvement

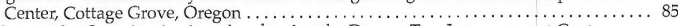

Figure 6.8 - Containerized seed orchard at the Dorena Tree Improvement Center,

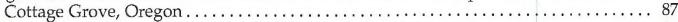

Figure 7.1-Volume of Port-Orford-Cedar exported $1961-1997$. . . . . . . . . . . . 95

Figure 7.2-Harvest levels by ownership sector in the United States . . . . . . . . . 95

Figure 7.3-Value of exported Port-Orford-Cedar 1990-1997 .................. 96

Figure 7.4_Domestic values of milled Port-Orford-Cedar $1990-1998 \ldots \ldots \ldots \ldots \ldots .96$

Figure 7.5-Logging decks of Port-Orford-Cedar in the Coquille area of Oregon, 1939. 97

Figure 7.6 - A cabin built of Port-Orford-Cedar near Powers, Oregon . . . . . . . . . . 97

Figure 7.7-Value of domestic and exported Port-Orford-Cedar $1990-1997$. . . . . . . 98

Figure 7.8 - Arrow shafts awaiting grading and sorting $\ldots \ldots \ldots \ldots \ldots \ldots \ldots, 100$

Figure 7.9-Bolts of Port-Orford-Cedar to be used for producing arrow shafts....... 100

Figure 7.10-Port-Orford-Cedar being cultivated for bough production . . . . . . . . 101

Figure 7.11-Number of jobs associated with Port-Orford-Cedar 1990-1997 . . . ... 102

Figure 8.1-Teresa Gallager-Hill, BLM Realty Specialist, discussing reciprocal

right-of-way and road use agreements on a public tour near Williams, Oregon. . . . 112

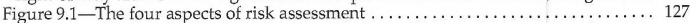

Figure 9.2-The relationships of strategy to the risk, effort, and acceptance of

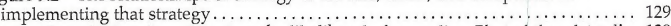

Figure 10.1-Surfaced roads reduce the likelihood of spreading Phytophthora lateralis. 139

Figure 10.2 -Reciprocal Right of Way Agreements......................... 140

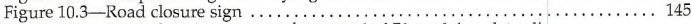

Figure 10.4-Road closed to prevent the spread of Phytophthora lateralis

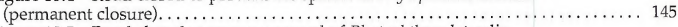

Figure 10.5-Road closed to prevent spread of Phytophthora lateralis

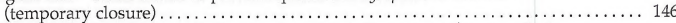

Figure 10.6-Roadside sanitation treatment to help prevent the spread of

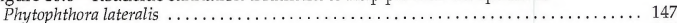

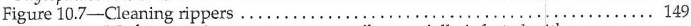

Figure 10.8-Washing equipment to remove soil potentially infested with Phytophthora lateralis 
Figure 10.9-Washing a log truck to remove soil potentially infested with

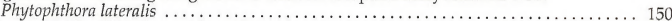

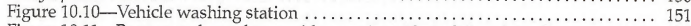

Figure 10.11 -Boots are cleaned to avoid spreading Phytophthora lateralis ........... 154

\section{Table of Tables}

Table 2.1-Important variables in gradient analyses which describe the distribution of Port-Orford-Cedar by ecoregion and subsection ....................... 9

Table 2.2 - Significant environmental factors affecting Port-Orford-Cedar by

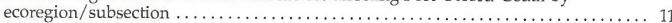

Table 2.3-Number of species by layer found on Port-Orford-Cedar plots in

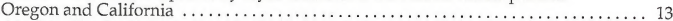

Table 2.4-Productivity indices for 26 California Port-Orford-Cedar plant associations (Jimerson and Daniels 1994, Jimerson et al. 2000).......................... 25

Table 2.5-Snag and down wood characteristics for Oregon Port-Orford-Cedar plant associations which occur on ultramafic soils ........................ 26

Table 2.6 - Snag and down wood characteristics for Oregon Port-Orford-Cedar plant associations which occur in cool, dry environments ..................... 26

Table 2.7-Snag and down wood characteristics for Oregon Port-Orford-Cedar plant associations that are codominant with western hemlock ................. 27

Table 2.8 - Snag densities (snags per acre) in Port-Orford-Cedar Series and Tanoak-

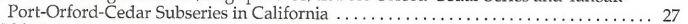

Table 2.9-Down wood densities (pieces per acre) in Port-Orford-Cedar Series and Tanoak-Port-Orford-Cedar Subseries in California $\ldots \ldots \ldots \ldots \ldots \ldots \ldots \ldots \ldots .28$

Table 4.1-Approximate percentages of acres in different federal land allocations over the range of Port-Orford-Cedar and percentage of those acres inhabited by

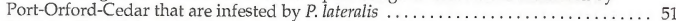

Table 4.2-Port-Orford-Cedar plant communities at risk (more than 10 percent infested by $P$. lateralis) in California (Jimerson et al. 1999) . . . . . . . . . . . . . . . 52

Table 5.1-Port-Orford-Cedar population samples by watershed for the common garden study (ecological model)

Table 5.2 - Port-Orford-Cedar population samples by tentative breeding zones for the common garden study (breeding model).

Table 5.3-Description of location and seed zones for Port-Orford-Cedar breeding blocks

\section{9} 11 26

Table 6.1-Number of Port-Orford-Cedar selections for breeding from initial resistance screening.

Table 6.2-Percent mortality after one year for three test methods for six of 44 openpollinated seedling families tested in $2000 \ldots \ldots \ldots \ldots \ldots \ldots \ldots \ldots \ldots \ldots \ldots . \ldots \ldots 2$

Table 7.1-Port-Orford-Cedar inventory from Forest Service and Bureau of Land

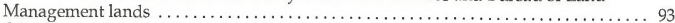

Table 7.2 -Summary of Port-Orford-Cedar timber taxes (1997 tax year) $\ldots \ldots \ldots \ldots \ldots \ldots$

Table 7.3-Annual regional economic contribution of Port-Orford-Cedar (1997 tax year) 104

Table 9.1-Factors that influence risk of infection of Port-Orford-Cedar by P. lateralis, their level of risk (high, medium, or low), and our ability to change or control the level of risk (high, medium, or low) ............................... 131

Table D.1-Analysis of variance (ANOVA) for height traits for watershed and breed

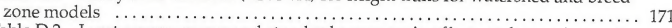

Table D.2-Least square means and standard errors main effects and some interactions for the watershed model for height (in centimeters) traits ............... 172

Table D.3-Least square means and standard errors main effects and some interactions for the breed zone model for height (in centimeters) traits . . . . . . . . . . . . 173

Table D.4-Distribution of variance components (\%) for height traits using the watershed model . ........................................ 174

Table D.5-Distribution of variance components $(\%)$ for height traits using the breed zone model 


\section{Executive Summary}

This assessment, a coordinated effort between the U.S. Department of the Interior Bureau of Land Management (BLM) and the U.S. Department of Agriculture Forest Service, describes associated ecological factors, pathology, and genetics of Port-Orfordcedar (Chamaecyparis lawsoniana). It also explores social and economic factors that may influence potential management strategies for the species on federal lands.

Port-Orford-cedar is a valuable tree with a limited natural range in southwestern Oregon and northwestern California. Port-Orford-cedar occurs on five National Forests, three BLM Districts, one National Park, and one National Monument, as well as on tribal, state, county, and private lands.

Port-Orford-cedar plant associations display some of the richest and most varied shrub and herbaceous plant associations in the region. Eleven rare and sensitive plant species are found exclusively in Port-Orford-cedar associations. Many of these plant. associations in the southern part of the tree's range occur in very restricted areas, mostly in wetlands or riparian areas, where the impacts of Port-Orford-cedar root disease can have noteworthy effects. Port-Orford-cedar can contribute a high percentage of stream shading. Loss of this ecosystem function can detrimentally impact other resources such as water quality and fish habitat.

Port-Orford-cedar is affected over much of its range by Phytophthora lateralis, a virulent, non-native root pathogen that is believed to have been introduced into the host's native range in the early 1950 s. P. lateralis kills Port-Orford-cedars of all ages that are growing on sites favorable for disease development. Once an area becomes infested, it is difficult, if not impossible, to eradicate the pathogen.

$P$. lateralis can spread rapidly if preventive actions are not taken to slow or stop it. Most spread of Port-Orford-cedar root disease occurs in the cool, rainy months of the year, usually from October 1 through May 31 . The greatest disease impacts are encountered among hosts growing in wetlands and riparian zones. Port-Orford-cedars growing in upland situations often escape infection even when the pathogen is established in lowlying areas or nearby drainages.

Approximately 91 percent of Forest Service and BLM land within the range of PortOrford-cedar in Oregon and California is uninfested with P. lateralis. Within the Riparian Reserve land allocation, it is estimated that 87 percent of the area is uninfested.

Low genetic variability--measured by differences in survival, growth, and vigor--has been demonstrated within populations growing in different parts of the tree's range. Growth differences are most noteworthy at different elevations and on different soil types. Breeding zones, within each breeding block, based on elevation bands have been delineated for the purpose of maintaining site adaptability in the Port-Orford-cedar breeding program.

A small amount of natural resistance to $P$. lateralis has been shown to exist in some PortOrford-cedar populations and appears to be heritable. An effort is underway by the federal agencies and Oregon State University to further identify and enhance root disease resistance in Port-Orford-cedar.

A variety of management techniques are used to decrease the probability, or prevent the spread, of $P$. lateralis in existing Port-Orford-cedar stands on federally-administered land. These include: planning access routes and timing projects to minimize the likelihood of $P$. lateralis spread; vehicle and equipment washing; vehicle exclusion; temporary road 
closures; integrating disease treatment with road design, engineering and maintenance; roadside sanitation; using care in water source selection and treatment; educational efforts; and genetic resistance breeding.

Port-Orford-cedar root disease management may involve a combination of disease management techniques that reduce the probability of disease spread and intensity across a landscape. Major factors to consider with root disease management are the occurrence and distribution of Port-Orford-cedar and P. lateralis in a planning area, the occurrence, locations and use patterns of roads, and the locations of streams and drainage patterns.

The objective of this document is to provide information to assist managers in maintaining Port-Orford-cedar throughout its range, both in presence and ecological function. 


\section{Chapter 1 \\ Introduction}

Authors: John T. Kliejunas and Donald L. Rose 
A Range-Wide Assessment of Port-Orford-Cedar on Federal Lands 
Port-Orford-cedar (Chamaecyparis lawsoniana [A. Murr.] Parl.) is an ecologically and economically important tree species. Its natural range is geographically limited to southwestern Oregon and northwestern California, but within that area, it occupies a broad environmental range (fig. 1.1). Port-Orford-cedar can be an important component of the riparian community, providing stability and shading. It can be found on ultramafic soils as well as non-ultramafic soils. Top quality Port-Orford-cedar logs have been valued as high as $\$ 12,000$ per thousand board feet. Some of the properties of the wood that make it noteworthy are its precise machining capability, decay resistance, resistance to chemical corrosion, and aromatic quality. It is particularly prized in Japan.

Port-Orford-cedar is affected by an exotic root pathogen, Phytophthora lateralis (fig. 1.2) (Tucker and Milbrath), which was first documented in a nursery near Seattle, Washington, in 1923. The pathogen is believed to have spread south via infected nursery stock and infested soil, and was first reported in the natural range of Port-Orford-cedar in 1952 near Coos Bay, Oregon. By 1960, infected trees were found on the Siskiyou National Forest, and surveys in 1964, 1974, 1983 and 1986 showed increasing levels of infestation and tree mortality. Infected trees were first identified in California in 1980. The pathogen now infects Port-Orford-cedar on about nine percent of the acreage of federallyadministered lands within the range of the species. Most of this acreage is on sites of high risk to spread the pathogen, i.e., along streams and roads.

In the late 1980 s and early 1990s, public awareness of Port-Orford-cedar and the root disease affecting it reached a high level. In response to public interest and the agencies' own concerns, the U.S. Department of Agriculture Forest Service and U.S. Department of the Interior Bureau of Land Management (BLM) greatly increased their efforts to

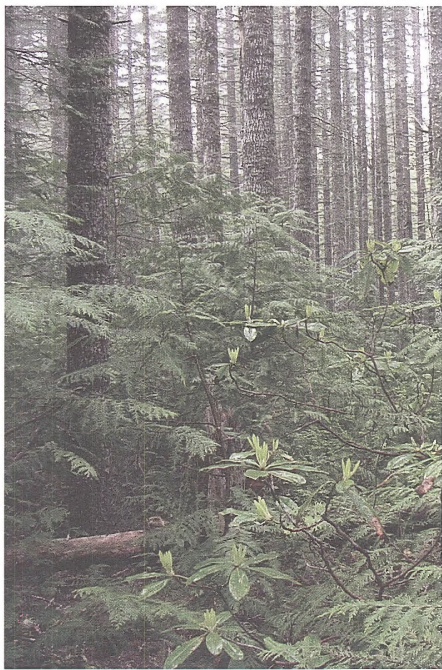
conserve Port-Orford-cedar and reduce the occurrence of P. lateralis.

In 1985, Zobal et al. produced a monograph, Ecology, Pathology, and Management of Port-Orford-Cedar, which reviewed the then current information on distribution, physiology, genetics, autecology, and pathology of Port-Orford-Cedar. They also proposed management options to limit the impacts of $P$. lateralis.

This range-wide assessment is intended to supplement the information Zobel et al. (1985) presented. It focuses on the status of Port-Orford-cedar on federal lands throughout the range of the species. Chapter 2, Ecological Factors Associated with Port-Orford-cedar, describes the distribution

Figure 1.1-Dense understory of Port-Orfordcedar near Coos Bay, Oregon 
of Port-Orford-cedar, as well as the geographic units and the broad climatic regimes in which it occurs. It also describes the high diversity of plant associations that make up the Port-Orford-cedar plant series, and lists some of the endemic, rare or unique plants that grow in association with it. Chapter 3 outlines the biology of the pathogen, P. lateralis. The impact of $P$. lateralis on Port-Orford-cedar is summarized in Chapter 4. It shows disease locations over time and rates of spread at local and landscape scales. Chapter 5 describes the genetic variability of Port-Orford-cedar across its range and the tests for genetic differentiation. Developing resistant genotypes of Port-Orford-cedar is an important strategy in conserving the species in its natural range. Chapter 6 describes the resistance-screening program that allows selection of resistant genotypes and how they may be propagated.

Chapter 7 discusses the economics of the species and compares domestic and imported volumes and values. Chapter 8 presents the value of Port-Orford-cedar particularly to Native American and Asian peoples. It includes two examples of local community or public involvement in Port-Orford-cedar management. Chapter 9 shows the components of risk analysis and discusses how such analyses may be used in management decisions. Management techniques and challenges are described in Chapter 10.

The objectives of this document are to assemble the known scientific information on PortOrford-cedar and P. lateralis for federal lands since Zobel et al. (1985) and review current societal values and associated considerations for management of Port-Orford-cedar.

This assessment is not a decision document. It contains information that could be used to guide future supplements or revisions of Forest Service or BLM management plans. If new plans are developed or current plans revised, public comment will occur during the process as required by the National Environmental Policy Act. Appendix A shows the relationship of this document to other legal documents and authorities.

\section{Literature Cited}

Zobel, D.B.; Roth, L.F.; Hawk, G.M. 1985. Ecology, pathology, and management of PortOrford-cedar (Chamaecyparis lawsoniana). General Technical Report PNW-184. Portland, OR: U.S. Department of Agriculture, Forest Service, Pacific Northwest Forest and Range Experiment Station. $161 \mathrm{p}$.

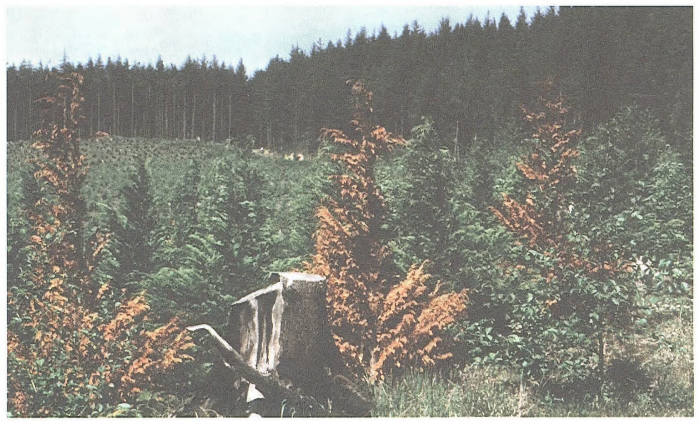

Figure 1.2-Infected Port-Orford-Cedar 


\section{Chapter 2 Ecological Factors Associated with Port-Orford-Cedar}

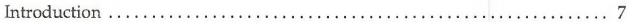

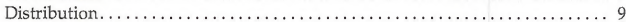

Ecoregion and Subsection Descriptions ...................... 10

Northern Coast. . . . . . . . . . . . . . . . . . . . . . . . . . 10

North Inland . . . . . . . . . . . . . . . . . . . . . . . . . . 11

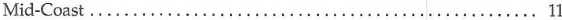

Mid-Range. ................................... 12

East Disjunct California $\ldots \ldots \ldots \ldots \ldots \ldots \ldots \ldots \ldots \ldots \ldots \ldots \ldots, 12$

Southern Range ................................ 12

Diversity $\ldots \ldots \ldots \ldots \ldots \ldots \ldots \ldots \ldots \ldots \ldots \ldots \ldots \ldots \ldots, 13$

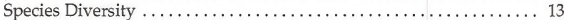

Plant Series and Plant Association Diversity ................ 13

Productivity Indices. . . . . . . . . . . . . . . . . . . . . . . . . . . . . 24

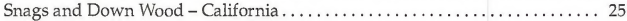

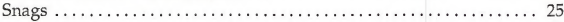

Down Wood $\ldots \ldots \ldots \ldots, \ldots \ldots \ldots \ldots, \ldots \ldots \ldots, \ldots \ldots \ldots, 27$

Function in Riparian Systems. . . . . . . . . . . . . . . . . . . . 29

Port-Orford-Cedar Plant Associations with Unique Species and Regional

Endemic, Rare or Sensitive Plants . . . . . . . . . . . . . . . . . . . 30

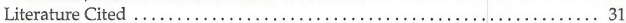

Authors: Thomas M. Jimerson, Diane E. White, Thomas Atzet, Christopher S. Park, Elizabeth A. McGee, Donald L. Rose, Lisa D. Hoover and Maria T. Ulloa 
A Range-Wide Assessment of Port-Orford-Cedar on Federal Lands 


\section{Introduction}

Port-Orford-cedar is found from southwestern Oregon to northwestern California, primarily in the Coast Ranges and Siskiyou and Klamath Mountains, with a small disjunct population in the Scott Mountains of California (fig. 2.1).

Although it has a narrow geographic distribution, it occupies many different environments. It is found at elevations from sea level to 6,400 feet. It may be found in glacial basins, along stream sides, on terraces, and on mountain side-slopes from lower to upper one-third slope positions. Soils where Port-Orford-cedar is found are derived from many parent materials, including sandstone, schist, phyllite, granite, diorite, gabbro, serpentine, peridotite, and volcanics. They are primarily Entisols, Inceptisols, Alfisols and Ultisols included in the mesic and frigid temperature regimes. Port-Orford-cedar shows adaptability to a wide range of summer evapo-transpiration stress, from very high humidities along the coast to very low summer humidities inland. The great ecological amplitude of Port-Orford-cedar is believed to reflect a geographic concentration of genetically based characteristics that developed in a larger geographic range that included parts of Idaho, Montana, California, Oregon, and extended as far east as Nebraska, 10 to 52 million years ago (Edwards 1983).

\section{Range of Port-Orford-cedar}

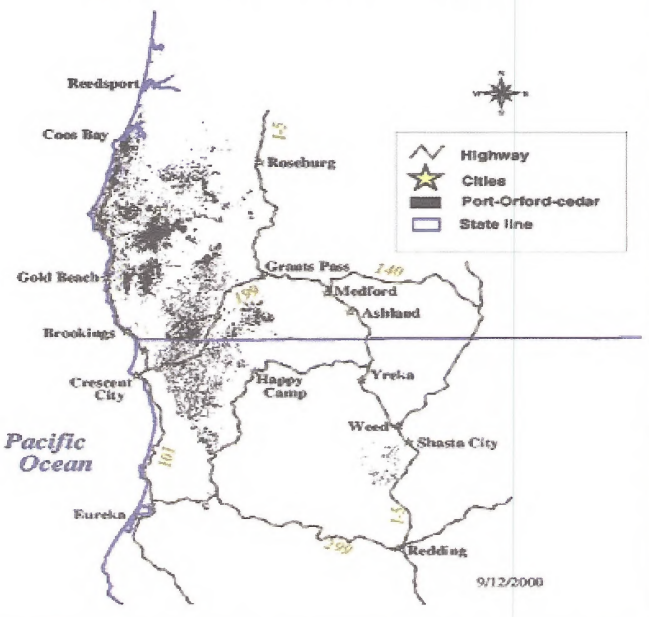

Figure 2.1-The native range of Port-Orford-cedar 


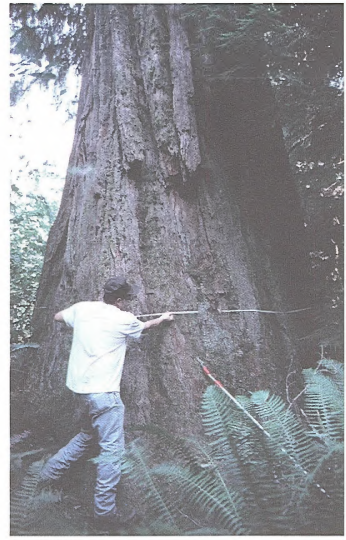

Figure 2.2-The world's largest PortOrford-cedar growing near Powers, Oregon

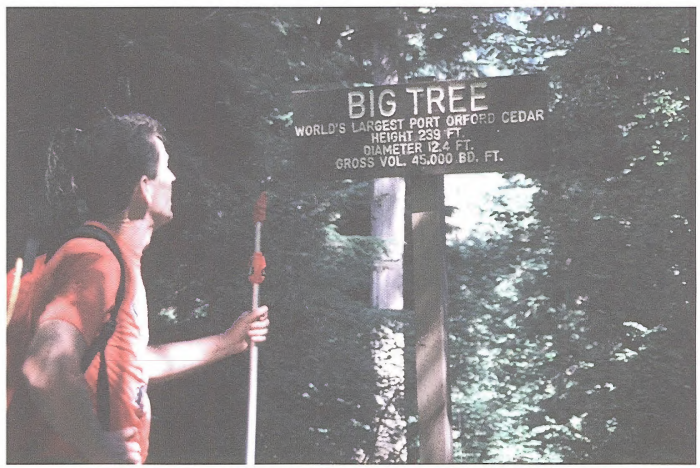

Figure 2.3-The world's largest Port-Orford-cedar growing near Powers, Oregon

Port-Orford-cedar plant associations characterize the broad range of habitats in which Port-Orford-cedar is found. These plant communities display some of the richest plant species diversity of all forest types in the region (Jimerson and Creasy 1991).

Port-Orford-cedar can be found with a variety of species with differing ecological requirements. These species change across the range of Port-Orford-cedar. For instance, in the northwestern portion of the range, Port-Orford-cedar is found in association with 
western hemlock (Tsuga heterophylla [Raf.] Sarg.), in the southwest with coastal redwood (Sequoia sempervirens [D. Don] Endl.) and tanoak (Lithocarpus densiflora [H. \& A.] Rehd.), in the central portion with Douglas-fir (Pseudotsuga menziesii [Mirb.] Franco.), and at higher elevations in the eastern portion of its range with white fir (Abies concolor [Gord. \& Glend.] Lindl.), western white pine (Pinus monticola Dougl.), Shasta red fir (Abies magnifica var. shastensis) and mountain hemlock (Tsuga mertensiana [Bong.] Carr.). Port-Orfordcedar has been noted as a component of more than 88 plant associations in Oregon and California (Atzet et al. 1996, Jimerson and Daniel 1994, Jimerson et al. 1995, Jimerson et al. 1996, Jimerson and Creasy 1997, Jimerson et al. 2000).

The wide ecological amplitude of Port-Orford-cedar is also reflected in the climatic diversity of the ecoregions and subsections in which it is distributed. These ecological units are defined based on biotic and environmental factors that directly affect ecosystem function (McNab and Avers 1994).

\section{Distribution}

Overall, the ecological units with unique plant associations are in the cooler, wetter (more northern) environments (Mid-Coastal Sedimentary and Southern Oregon Coastal Mountains), the inland (Inland Siskiyous/Siskiyou Mountains) or inland, high elevation environments (Upper Scotts Mountains). Gradient analyses showed different environmental variables were important in describing the distribution of Port-Orfordcedar between the different ecoregions and subsections (table 2.1).

Table 2.1-Important variables in gradient analyses which describe the distribution of PortOrford-cedar by ecoregion and subsection ${ }^{1}$

\begin{tabular}{|c|c|c|}
\hline Ecoregion/Subsection & Axis 1 Variable & Axis 2 Variable \\
\hline \multicolumn{3}{|l|}{ Northern Coast } \\
\hline $\begin{array}{l}\text { Mid-Coastal Sedimentary } \\
\text { Southern Oregon Coastal }\end{array}$ & $\begin{array}{l}\text { Ultramafic parent material } \\
\text { Elevation }\end{array}$ & \\
\hline \multicolumn{3}{|l|}{ North Inland } \\
\hline $\begin{array}{l}\text { Inland Siskiyous } \\
\text { Siskiyou Mountains }\end{array}$ & $\begin{array}{l}\text { Elevation } \\
\text { Macroposition }\end{array}$ & $\begin{array}{l}\text { Metamorphic rock } \\
\text { Microposition }\end{array}$ \\
\hline \multicolumn{3}{|l|}{ Mid-Coast } \\
\hline Coastal Siskiyous & $\begin{array}{l}\text { Ultramafic parent material } \\
\text { Surface coarse fragments }\end{array}$ & $\begin{array}{l}\text { Surface coarse fragments } \\
\text { Mean annual temperature }\end{array}$ \\
\hline \multicolumn{3}{|l|}{ Mid-Range } \\
\hline $\begin{array}{l}\text { Serpentine Siskiyous } \\
\text { Gasquet Mountain Ultramafics }\end{array}$ & $\begin{array}{l}\text { Distance to ocean } \\
\text { Surface rock } \\
\text { Ultramafic parent material }\end{array}$ & Elevation \\
\hline Western Jurassic & $\begin{array}{l}\text { Ultramafic parent material } \\
\text { Macroposition }\end{array}$ & \\
\hline \multicolumn{3}{|l|}{ East Disjunct California } \\
\hline $\begin{array}{l}\text { Eastern Klamath Mountains } \\
\text { Lower Scott Mountains } \\
\text { Upper Scott Mountains }\end{array}$ & $\begin{array}{l}\text { Elevation } \\
\text { Moisture stress } \\
\text { Mean annual temperature } \\
\text { Microposition }\end{array}$ & $\begin{array}{l}\text { Aspect } \\
\text { Direct solar radiation }\end{array}$ \\
\hline \multicolumn{3}{|l|}{ Southern Range } \\
\hline Eastern Franciscan & Not analyzed & \\
\hline $\begin{array}{l}\text { Pelletreau Ridge } \\
\text { Rattlesnake Creek }\end{array}$ & $\begin{array}{l}\text { Precipitation } \\
\text { Moisture stress } \\
\text { Metamorphic parent material } \\
\text { Ultramafics }\end{array}$ & $\begin{array}{l}\text { Elevation } \\
\text { Microposition }\end{array}$ \\
\hline
\end{tabular}

Jjimerson, T.M. 1999. Personal communication. Ecologist, Six Rivers National Forest, 1330 Bayshore Way, Eureka, CA 95501. 
Two types of ecological units were used to describe the distribution of Port-Orford-cedar, level IV ecoregions in Oregon (USEPA 1998) and subsections in California (Miles and Goudey 1997). The ecological subsections are the lowest division of regional ecosystems mapped in California and the level IV ecoregions are the lowest division of ecoregions mapped in Oregon. Ecoregions and subsections are configured and delineated differently because they are based on two different methods of mapping ecosystems. The main difference between these two approaches is that land use or human disturbance is used as a factor in separating ecoregions, while subsections are separated by differences in management prescriptions. The ecoregions and subsections are shown in figure 2.4 and characterized in table 2.2 .

\section{Ecoregion and Subsection Descriptions}

\section{Northern Coast}

The Mid-Coastal Sedimentary and Southern Oregon Coastal Mountains-These ecoregions are part of the Oregon Coast Range. This is an area of low mountains with high rainfall and dense coniferous forests. It has moderately sloping, dissected mountains and sinuous streams. The most important characteristic in terms of species composition is the occurrence of western hemlock as a dominant or codominant species. Ten plant associations with Port-Orford-cedar were identified in these ecoregions, and five were found only in these ecoregions.

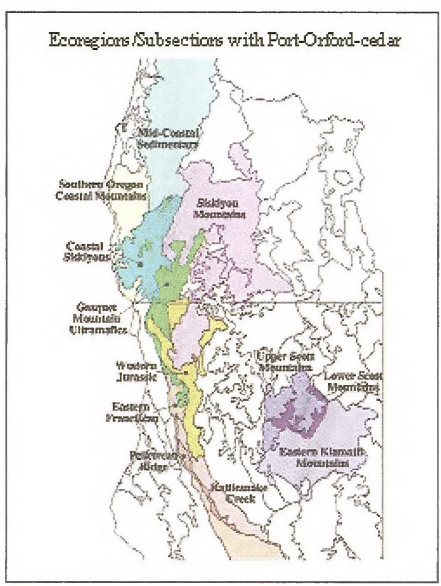

Figure 2.4-Ecoregions and subsections with Port-Orford-cedar occurrence 
Table 2.2-Significant environmental factors affecting Port-Orford-cedar by ecoregion/ subsection

\begin{tabular}{|c|c|c|c|c|c|c|c|}
\hline Ecoregion/Subsection & $\begin{array}{c}\text { Area } \\
\text { (acres) }\end{array}$ & $\begin{array}{l}\text { Elevation } \\
\text { (feet) }\end{array}$ & $\begin{array}{l}\text { Precipi-tation. } \\
\text { (inches) }\end{array}$ & $\begin{array}{l}\text { Distance } \\
\text { to Ocean } \\
\text { (miles) }\end{array}$ & $\begin{array}{l}\text { Mean } \\
\text { July } \\
\text { Temp. } \\
\text { (F.) }\end{array}$ & $\begin{array}{l}\text { Mean } \\
\text { Jan. } \\
\text { Temp. } \\
\text { (F.) }\end{array}$ & $\begin{array}{l}\text { Predominant } \\
\text { Parent Material }\end{array}$ \\
\hline $\begin{array}{l}\text { Mid-Coastal } \\
\text { Sedimentary }\end{array}$ & $2,303,227$ & $300-2000$ & $60-130$ & $3-45$ & $48-78$ & $32-48$ & $\begin{array}{l}\text { siltstone } \\
\text { sandstone }\end{array}$ \\
\hline $\begin{array}{l}\text { Southern Oregon } \\
\text { Coastal Mountains }\end{array}$ & 443,116 & $0-3400$ & $70-140$ & $0-28$ & $52-76$ & $36-52$ & complex \\
\hline Coastal Siskiyous & 545,604 & $1000-4800$ & $70-140$ & $7-30$ & $50-76$ & $38-50$ & $\begin{array}{l}\text { conglomerate w/ } \\
\text { sandstone }\end{array}$ \\
\hline Eastern Franciscan & $1,251,951$ & $1200-8092$ & $40-120$ & data gap & 55 & 35 & metaclastic rocks \\
\hline $\begin{array}{l}\text { Serpentine Siskiyous/ } \\
\text { Gasquet Mountain } \\
\text { Ultramafics }\end{array}$ & 400,980 & $200-4800$ & $45-140$ & $6-45$ & 57 & 46 & ultramafic \\
\hline Western Jurassic & data gap & $250-4000$ & $50-120$ & $7-45$ & 57 & 45 & $\begin{array}{l}\text { ultramafic } \\
\text { sedimentary }\end{array}$ \\
\hline $\begin{array}{l}\text { Inland Siskiyous/ } \\
\text { Siskiyou Mountains }\end{array}$ & $1,862,497$ & $1000-7309$ & $35-100$ & $13-57$ & 53 & 40 & $\begin{array}{l}\text { metasedimentary } \\
\text { peridotite } \\
\text { granitics }\end{array}$ \\
\hline Pelletreau Ridge & 73,915 & $1500-5000$ & $60-80$ & $20-25$ & 54 & 45 & sedimentary \\
\hline Rattlesnake Creek & 312,703 & $400-5881$ & $40-60$ & $20-25$ & 57 & 45 & metavolcanic \\
\hline Eastern Klamath & data gap & $1950-3000$ & 70 & 84 & 56 & 42 & $\begin{array}{l}\text { metavolcanic } \\
\text { metasedimentary }\end{array}$ \\
\hline Lower Scott Mountains & 127,297 & $1500-5000$ & $40-60$ & $60-90$ & 55 & 45 & $\begin{array}{l}\text { ultramafic } \\
\text { granitic }\end{array}$ \\
\hline Upper Scott Mountains & 389,795 & $4000-9025$ & $30-70$ & $60-90$ & 45 & 30 & $\begin{array}{l}\text { ultramafic } \\
\text { granitic }\end{array}$ \\
\hline
\end{tabular}

\section{North Inland}

Inland Siskiyous and Siskiyou Mountains-This ecoregion and subsection has higher, steeper terrain than the other ecoregions and subsections. It has a high diversity of conditions, which is reflected in the vegetation. The vegetation is dominated by the Douglas-fir Series at low elevations, Jeffrey Pine Series on ultramafic soils, and White Fir and Red Fir Series at higher elevations. Sixty-two plant associations containing PortOrford-cedar were identified in this ecoregion and subsection, and many are exclusive or have their greatest extent here.

\section{Mid-Coast}

The Coastal Siskiyous-The Coastal Siskiyous Ecoregion is located in Oregon and is an area with highly dissected mountains and high gradient streams, as well as a few, small, alpine glacial lakes. The climate is wetter with more maritime influence than elsewhere in the Klamath Mountains bioregion. This area has tanoak, Douglas-fir, and some Port-Orford-cedar. Western hemlock is not a dominant overstory species. Nine plant associations were identified in this ecoregion that contain Port-Orford-cedar, with a high frequency of plant associations on serpentine soils. 


\section{Mid-Range}

The Serpentine Siskiyous/Gasquet Mountain Ultramafics-This ecoregion and subsection is dominated by the Tanoak-Port-Orford-cedar Subseries (Port-Orford-cedar is codominant with tanoak). In Oregon, the White Fir Series and the Port-Orford-cedarWhite Fir Subseries are fairly common and occur at relatively high elevations (up to 4800 feet) and a long distance inland (up to 45 miles). The Port-Orford-cedar-Douglas-fir and Port-Orford-cedar-Western White Pine Subseries are more common in California, the latter being correlated with ultramafic rock.

The Western Jurassic - Marine air moderates temperatures in the western portion of this subsection creating a temperate to humid climate. The Douglas-fir and Tanoak Series dominate this subsection. Twenty-two plant associations containing Port-Orford-cedar are described in this subsection, none are found only here. This subsection has the second highest amount of Port-Orford-cedar of all subsections in Northern California.

\section{East Disjunct California}

Eastern Klamath Mountains-This subsection is located on the farthest southeastern corner of the Klamath Mountains. It has two plant associations with Port-Orford-cedar; neither is unique to this subsection.

Lower Scott Mountains-This subsection comprises the low elevation portion of the Eastern Klamath geologic belt of the Klamath Mountains. Ultramafic rocks of the Trinity Terrane and intrusions of granitic rocks dominate the geology of this area. The Jeffrey Pine, Ponderosa Pine, White Fir, and Douglas-fir Series are the dominant vegetation in this subsection. Five Port-Orford-cedar plant associations are present.

Upper Scott Mountains-This subsection comprises the high elevation portion of the Eastern Klamath geologic belt of the Klamath Mountains. The geology is the same as the Lower Scott Mountains Subsection. Thirteen plant associations with Port-Orford-cedar are found here, seven are unique to this subsection, and three additional Port-Orfordcedar plant associations are predominantly found here.

\section{Southern Range}

The Eastern Franciscan-The Eastern Franciscan Subsection represents the high elevation portion of the northern California Coast Ranges. There are 16 Port-Orfordcedar plant associations in this subsection. None of the plant associations are unique to the subsection, and most are extensions of what is found in the Gasquet Mountain Ultramafics, Western Jurassic, and Siskiyou Mountain subsections.

Pelletreau Ridge - This subsection is a narrow, arcuate strip of land along the southwest edge of the Klamath Mountains. Port-Orford-cedar stands here are 20 miles south and 50 miles west of the nearest other stands of Port-Orford-cedar, although there are no unique plant associations here. The vegetation in this region is dominated by Douglas-fir and Tanoak Series, with White Fir Series at higher elevations (Miles and Goudey 1997).

Rattlesnake Creek-This is also an arcuate subsection that is within the Western Paleozoic and Triassic belts of the Klamath Mountains. The Douglas-fir, White Fir, and Ponderosa Pine Series dominate this subsection, with Jeffrey Pine Series on serpentinized peridotite (Miles and Goudey 1997). This subsection has a very small amount of PortOrford-cedar. There are no Port-Orford-cedar plant associations that are unique or reach their greatest extent here. 


\section{Diversity}

\section{Species Diversity}

Species diversity within Port-Orford-cedar stands is exemplified by the high number of species found per layer (table 2.3)

In the overstory tree layer alone, 29 species were identified. The shrub layer included 93 species, and the forb layer 446 species. Members of the tree and shrub layers were considered indicator species for environmental change. Species found in the shrub and forb layers help define the major and minor gradients and are used in the plant association classifications.

This high species diversity is typified by the wide ecological gradients in which PortOrford-cedar and its associated species are found. A gradient analysis, displayed in figure 2.5 , shows the first and most prominent gradient (axis 1 ) is most highly correlated with elevation $(r=0.93)$. This was evidenced by mountain hemlock occurring on the extreme negative side of the axis and coast redwood on the extreme positive side. The $X$ coordinate may also be thought of as distance to the ocean $(r=-0.54)$, December minimum temperature $(r=0.69)$, mean annual temperature $(r=0.61)$, indirect solar radiation $(r=0.49)$, and sedimentary rock $(r=0.33)$. Distance to the ocean incorporates a host of environmental factors including temperature extremes, humidity and fog.

Axis 2 was most highly correlated with ultramafic rock $(r=-0.32)$ and microposition $(r=0.30)$. These graphics demonstrate the wide environmental gradient included within the Port-Orford-cedar communities and are assumed, based on the work of Millar et al. (1991) using allozyme research, to represent genetic diversity. The species depicted in the figures help to define the major environmental gradients used to describe vegetation series and subseries.

\section{Plant Series and Plant Association Diversity}

The wide ecological amplitude of the Port-Orford-cedar Series is shown in figure 2.6. It occurs over similar environmental ranges as the Douglas-fir, White Fir, Jeffrey Pine, and Western White Pine Series and in portions of the environmental range of the Tanoak and Western Hemlock Series (figs. 2.7 and 2.8).

Table 2.3-Number of species by layer found on Port-Orford-cedar plots in Oregon and California

( $n=1076$ plots)

\begin{tabular}{|c|c|}
\hline Layer & Number of Species \\
\hline Overstory trees & 29 \\
\hline Understory trees & 32 \\
\hline Shrubs & 93 \\
\hline Forbs & 446 \\
\hline Grasses & 44 \\
\hline
\end{tabular}




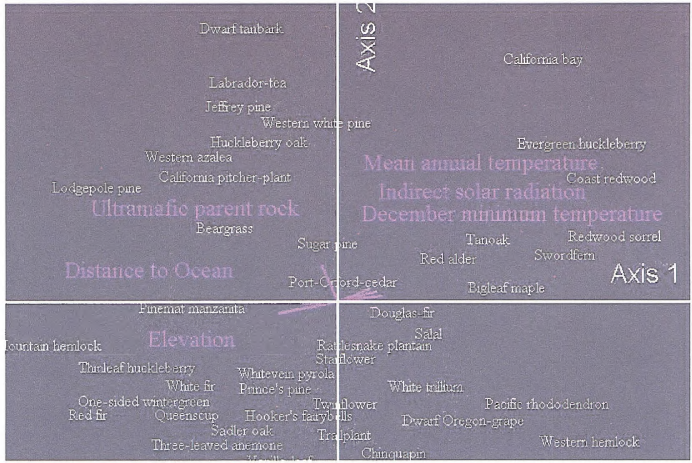

Figure 2.5-The relationship of species commonly found in association with Port-Orford-cedar

Multivariate statistical analyses of data from plots in Oregon and California from the Port-Orford-cedar Series have resulted in a classification with 43 plant associations, eight from Oregon and 35 from California (Atzet et al. 1996, Jimerson and Daniel 1994, Jimerson, et al. 2000). The Tanoak-Port-Orford-cedar Subseries is made up of 13 plant associations with moderate to high amounts of Port-Orford-cedar. Thirty-two additional plant associations with Port-Orford-cedar occur in other plant series (Appendix B).

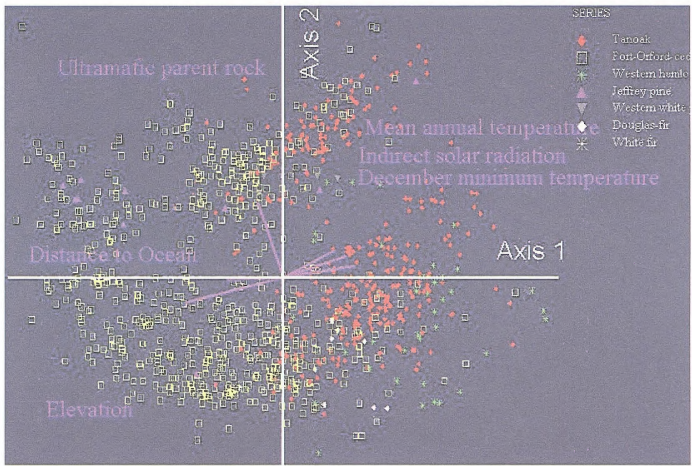

Figure 2.6-The relationship of plant series to environmental factors 
Chapter 2 -Ecological Factors Associated with Port-Orford-Cedar

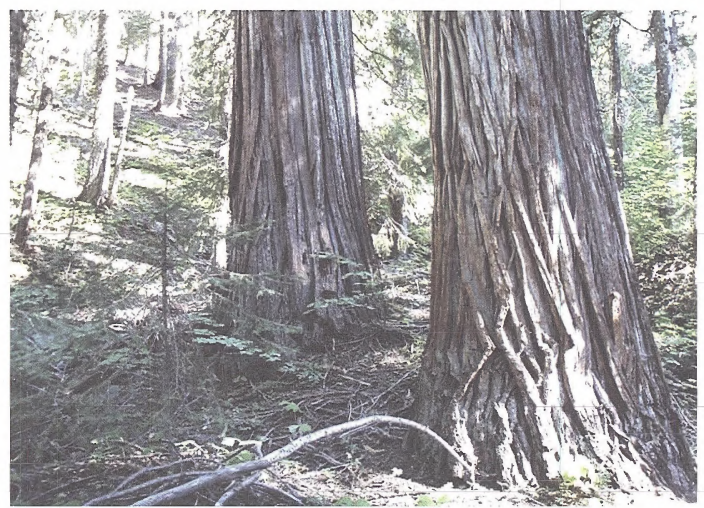

Figure 2.7-Port-Orford-cedar-White Fir/Herb plant association

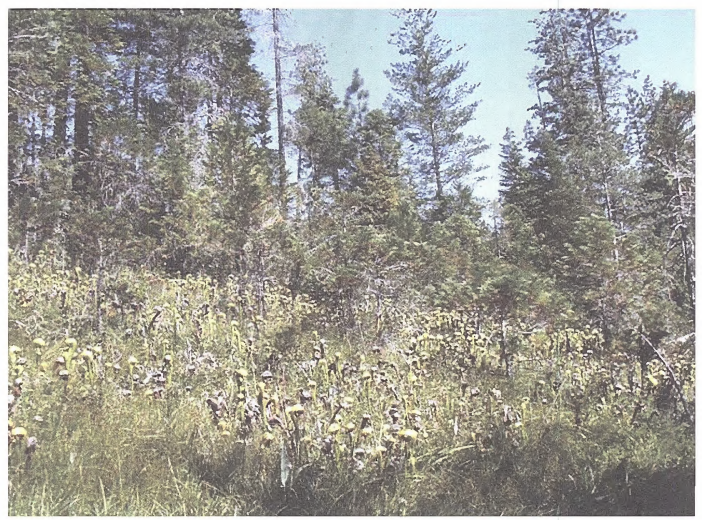

Figure 2.8-The Port-Orford-cedar-Western White Pine/California Pitcher Plant plant association 
Port-Orford-cedar plant associations occur in environments where Port-Orford-cedar is competitive relative to other tree species. The overall range of Port-Orford-cedar, however, includes plant associations from other plant series: western hemlock, Douglasfir, Jeffrey pine, tanoak and white fir. The species itself is more widely distributed than would be suggested by examining only the series distribution. Appendix B shows plant associations that contain significant amounts of Port-Orford-cedar and where they occur.

Some Port-Orford-cedar Series plant associations are described below.

In Oregon, two plant associations are described that occur on serpentine soils.

\section{CHLA/QUVA/XETE}

Port-Orford-cedar/Huckleberry Oak/Beargrass

Elevation mean: 4150 feet

Aspect: primarily northwest

Overstory: Douglas-fir and Port-Orford-cedar

Understory trees: Douglas-fir, Port-Orford-cedar, white fir and western white pine

Shrubs: huckleberry oak

Herb cover: 18 percent

CHLA/LOHI/FESTU

Port-Orford-cedar/Hairy Honeysuckle/Fescue

Elevation mean: 1690 feet

Aspect: primarily southwest

Overstory: Port-Orford-cedar

Understory trees: Port-Orford-cedar, Douglas-fir, sugar pine, Jeffrey pine, and occasionally California black oak

Shrubs: hairy honeysuckle and western azalea

Herb cover: 59 percent

Two plant associations are found in cool, dry environments, towards the east side of the range of Port-Orford-cedar in Oregon.

\section{CHLA-ABCO/BENE2}

Port-Orford-cedar-White Fir/Dwarf Oregon-grape

Elevation mean: 4165 feet

Aspect: all aspects

Overstory: Douglas-fir and Port-Orford-cedar

Understory trees: Port-Orford-cedar and white fir

Shrubs: dwarf Oregon-grape and bald hip rose

Herb cover: 27 to 32 percent

\section{CHLA-LIDE3/GASH}

Port-Orford-cedar-Tanoak/Salal

Elevation mean: 3330 feet

Aspect: all aspects

Overstory: Douglas-fir and Port-Orford-cedar

Understory trees: Port-Orford-cedar, tanoak, Douglas-fir, and occasionally white fir Shrubs: salal

Herb cover: 11 percent

Two Oregon plant associations have western hemlock as a co-dominant tree species. These are on the wet end of the environmental gradient for the Port-Orford-cedar Series in Oregon. 
CHLA-TSHE/POMU

Port-Orford-cedar-Western Hemlock/Swordfern

Elevation mean: 1810 feet

Aspect: all aspects

Overstory: Douglas-fir and Port-Orford-cedar

Understory trees: Port-Orford-cedar, western hemlock, Douglas-fir, and tanoak

Shrubs: Salal, Oregon-grape, and red huckleberry

Herb cover: 14 percent

CHLA-TSHE/LEDA

Port-Orford-cedar-Western Hemlock/Sierra-Laurel

Elevation mean: 3700 feet

Aspect: generally west

Overstory: Port-Orford-cedar and often western hemlock and Douglas-fir

Understory trees: Port-Orford-cedar and western hemlock

Shrubs: Sierra laurel and salal, often Pacific rhododendron and red huckleberry

Herb cover: 5 percent

Two additional plant associations are found in Oregon.

CHLA/VAOV2/POMU

Port-Orford-cedar/Evergreen Huckleberry/Western Swordfern

Elevation mean: 265 feet

Aspect: generally north

Overstory: Douglas-fir

Understory trees: Port-Orford-cedar and often western hemlock

Shrubs: Often evergreen huckleberry, salmonberry, red huckleberry, Pacific

rhododendron, dwarf Oregon-grape

Herb cover: very high

CHLA/RHMA3-GASH

Port-Orford-cedar/Pacific Rhododendron-Salal

Elevation mean: 1834 feet

Aspect: primarily north

Overstory: Douglas-fir, often Port-Orford-cedar

Understory trees: Port-Orford-cedar, often tanoak

Shrubs: often Pacific rhododendron, salal, Oregon-grape

Herb cover: 10 percent

California. There are 35 Port-Orford-cedar plant associations in northern California (Jimerson and Daniel 1994, Jimerson and DeNitto 2000), 21 from northwestern California and the remainder from the Trinity and Sacramento River drainages.

CHLA/GASH

Port-Orford-cedar/Salal

Elevation range: 2800 to 3740 feet

Aspect: north

Overstory: Douglas-fir and Port-Orford-cedar

Understory trees: Port-Orford-cedar, often tanoak

Shrubs: salal

Herb cover: 11 percent

Grass cover: 1 percent

\section{CHLA/RHMA3-GASH}

Port-Orford-cedar/Pacific Rhododendron-Salal

Elevation range: 2700 to 3600 feet

Aspect: northwest to northeast 
Soils: may be derived from serpentine parent rock

Overstory: Port-Orford-cedar, Douglas-fir, frequently chinquapin

Understory trees: Port-Orford-cedar, occasionally tanoak and chinquapin

Shrubs: Pacific rhododendron and red huckleberry, frequently salal

Forb cover: 8 percent

\section{CHLA/RHOC}

Port-Orford-cedar/Western Azalea

Elevation range: 2500 to 3940 feet

Aspect: northeast

Soils: derived from peridotite and serpentine

Overstory: Port-Orford-cedar and Douglas-fir

Understory trees: Port-Orford-cedar, frequently tanoak and Douglas-fir

Shrubs: Western azalea, frequently red huckleberry and trailing blackberry

Forb cover: 6 percent

Grass cover: 2 percent

\section{CHLA-ABCO/QUVA}

Port-Orford-cedar-White Fir/Huckleberry Oak

Elevation range: 2980 to 4620 feet

Aspect: northeast and west

Soils: derived from peridotite, greenstone, and serpentine

Overstory: Port-Orford-cedar, Douglas-fir, white fir, frequently sugar pine

Understory trees: Port-Orford-cedar and white fir, frequently Douglas-fir

Shrubs: Huckleberry oak

Forb cover: 14 percent

CHLA-ABCO-PIMO3/QUVA

Port-Orford-cedar-White Fir-Western White Pine/ Huckleberry Oak

Elevation range: 4360 to 5180 feet

Aspect: northwest

Soils: derived from ultramafic parent rock

Overstory: Port-Orford-cedar, Douglas-fir, white fir, western white pine

Understory trees: Port-Orford-cedar, white fir

Shrubs: Huckleberry oak, frequently pinemat manzanita, Sadler oak, wild rose

Forb cover: 8 percent

\section{CHLA-ABCO/RHOC}

Port-Orford-cedar-White Fir/Western Azalea

Elevation range: 3740 to 4320 feet

Aspect: northeast and south

Soils: derived from ultramafic parent rock

Overstory: Port-Orford-cedar, Douglas-fir, white fir

Understory trees: white fir, Port-Orford-cedar

Shrubs: western azalea, frequently huckleberry oak and trailing blackberry

Forb cover: 6 percent

Grass cover: 1 percent

\section{CHLA-ABCO//Herb}

Port-Orford-cedar-White Fir//Herb

Elevation range: 3600 to 4540 feet

Aspect: northwest, northeast, southwest

Overstory: Port-Orford-cedar, frequently white fir and Douglas-fir

Understory trees: Port-Orford-cedar and white fir are frequent

Shrubs: variable; trailing blackberry, wild rose, hazelnut, and Sadler oak may be present

Forb cover: 13 percent 
CHLA-ABCO/QUSA

Port-Orford-cedar-White Fir/Sadler Oak

Elevation range: 3220 to 4360 feet

Aspect: northwest and northeast

Overstory: Port-Orford-cedar and Douglas-fir, frequently white fir

Understory trees: frequently Port-Orford-cedar, white fir and Douglas-fir

Shrubs: Sadler oak, frequently red huckleberry, dwarf Oregon-grape, Oregon boxwood Forb cover: 22 percent

CHLA-ABMAS/QUSA-VAME

Port-Orford-cedar-Red Fir/Sadler Oak-Thinleaf Huckleberry

Elevation range: 4400 to 5270 feet

Aspect: north

Soils: occasionally soils derived from peridotite parent rock

Overstory: white fir and Port-Orford-cedar, frequently red fir and Douglas-fir

Understory trees: Port-Orford-cedar, red fir and white fir

Shrubs: Sadler oak, frequently thin-leaved huckleberry and dwarf Oregon-grape

Forb cover: 23 percent

\section{CHLA-PSME/QUVA}

Port-Orford-cedar-Douglas-fir/Huckleberry Oak

Elevation range: 2520 to 3720 feet

Aspect: northwest and east

Soils: derived from ultramafic parent rock

Overstory: Port-Orford-cedar and Douglas-fir, frequently sugar pine

Understory trees: Port-Orford-cedar, frequently Douglas-fir

Shrubs: huckleberry oak, frequently red huckleberry

Forb cover: 9 percent

\section{CHLA-PIMO3/QUVA}

Port-Orford-cedar-Western White Pine/Huckleberry Oak

Elevation range: 1500 to 3840 feet

Aspect: east and west

Soils: derived from ultramafic parent rock

Overstory: Port-Orford-cedar, Douglas-fir and western white pine

Understory trees: western white pine, frequently Port-Orford-cedar and Douglas-fir Shrubs: huckleberry oak, frequently red huckleberry, occasionally dwarf tanoak and boxleaf maple

Forb cover: 14 percent

Grass cover: 4 percent

\section{CHLA-LIDE3/ALRH}

Port-Orford-cedar-Incense cedar-White Alder

Elevation range: 3220 to 3390 feet

Aspect: southeast

Overstory: Port-Orford-cedar, Douglas-fir and white alder

Understory trees: Port-Orford-cedar

Forb cover: 3 percent

\section{CHLA-ABCO/ALSI2}

Port-Orford-cedar-White fir/Sitka alder

Elevation range: 3920 to 5050 feet

Aspect: mainly west and east

Overstory: Port-Orford-cedar, white fir, and Douglas-fir

Understory trees: Port-Orford-cedar, white fir, and Douglas-fir

Shrubs: Sitka alder, Sadler oak, wood rose

Forb cover: 33 percent

Grass cover: 5 percent 


\section{CHLA-PIMO3/RHOC-LIDEE-LEGL1}

Port-Orford-cedar-Western white pine/Western azalea-Dwarf tanbark-Labrador tea

Elevation range: 1320 to 3480 feet

Aspect: mainly southeast and west

Overstory: Port-Orford-cedar, western white pine, and Douglas-fir

Understory trees: Port-Orford-cedar, western white pine, and Douglas-fir

Shrubs: western azalea, dwarf tanbark, and western Labrador tea

Forb cover: 4 percent

Grass cover: 11 percent

\section{CHLA-PIMO3/LEGL1/DACA2//Coastal}

Port-Orford-cedar-Western white pine/Labrador tea/California pitcher plant//Coastal Elevation range: 550 to 3660 feet

Aspect: mainly southwest

Overstory: Port-Orford-cedar and western white pine

Understory trees: Port-Orford-cedar and western white pine

Shrubs: western Labrador tea, western azalea, and dwarf tanbark

Forb cover: 15 percent

Grass cover: 25 percent

\section{CHLA-ABCO/ACCI}

Port-Orford-cedar-White fir/Vine maple

Elevation range: 2750 to 4420 feet

Aspect: mainly north

Overstory: Port-Orford-cedar, white fir, and Douglas-fir

Understory trees: Port-Orford-cedar, white fir, and Douglas-fir

Shrubs: vine maple and dwarf Oregon-grape

Forb cover: 36 percent

Grass cover: 1 percent

\section{CHLA-ABMAS-PIBR/QUSA-QUVA}

Port-Orford-cedar-Shasta red fir-Brewer's spruce/Sadler oak-Huckleberry oak

Elevation range: 4850 to 5500 feet

Aspect: mainly northwest and northeast

Overstory: Port-Orford-cedar, Shasta red fir, and Brewer's spruce

Understory trees: Port-Orford-cedar, Shasta red fir, and Brewer's spruce

Shrubs: huckleberry oak, Sadler oak, thinleaf huckleberry

Forb cover: 12 percent

Grass cover: 1 percent

\section{CHLA-ABMAS/ALSI2-QUSA}

Port-Orford-cedar-Shasta red fir/Sitka alder-Sadler oak

Elevation range: 4520 to 5300 feet

Aspect: mainly north and northeast

Overstory: Port-Orford-cedar, Shasta red fir, and Douglas-fir

Understory trees: Port-Orford-cedar, Shasta red fir, and Douglas-fir

Shrubs: Sitka alder, Sadler oak, thinleaf huckleberry

Forb cover: 25 percent

Grass cover: 4 percent 
CHLA-PSME-ALRU2/ACCI-BENE1

Port-Orford-cedar-Douglas-fir-Red alder/Vine Maple-Oregon-grape

Elevation range: 1890 to 3140 feet

Aspect: mainly north

Overstory: Port-Orford-cedar, Douglas-fir, and red alder

Understory trees: Port-Orford-cedar, Douglas-fir, and red alder

Shrubs: vine maple, dwarf Oregon-grape, and California hazelnut

Forb cover: 32 percent

Grass cover: 2 percent

CHLA-PSME/COCOC

Port-Orford-cedar-Douglas-fir/California Hazelnut

Elevation range: 2740 to 4320 feet

Aspect: mainly east

Overstory: Port-Orford-cedar and Douglas-fir

Understory trees: Port-Orford-cedar and Douglas-fir

Shrubs: California hazelnut and Pacific blackberry

Forb cover: 49 percent

Grass cover: 1 percent

CHLA-ABMAS/ALSI2/DACA2

Port-Orford-cedar-Shasta red fir/Sitka alder/California pitcher plant

Elevation range: 5250 to 5480 feet

Aspect: mainly northwest and south

Overstory: Port-Orford-cedar, Shasta red fir, and mountain hemlock

Understory trees: Port-Orford-cedar, Shasta red fir, and mountain hemlock

Shrubs: Sitka alder, western azalea, slender salal

Forb cover: 53 percent

Grass cover: 48 percent

The following plant associations are unique to the Trinity and Sacramento River drainages. They occur on high elevation, inland sites; almost all are over 80 miles from the coast.

\section{CHLA-PSME/CAOC5}

Port-Orford-cedar-Douglas-fir/Spicebush

Elevation range: 1940 to 2550 feet

Aspect:_east

Soils: derived from ultramafic parent rock

Overstory: Port-Orford-cedar and Douglas-fir, frequently canyon live oak

Understory trees: Port-Orford-cedar and canyon live oak

Shrubs: Spicebush and frequently western azalea and coffeeberry

Forb cover: 4 percent

Grass cover: 5 percent

\section{CHLA-MCON/RHOC-LIDEE}

Port-Orford-cedar-Mixed Conifer/Western Azalea-Dwarf Tanbark

Elevation range: 2600 to 4160 feet

Aspect: east, south, and west

Soils: some derived from ultramafic parent rock

Overstory: Port-Orford-cedar and Douglas-fir, and frequently white fir Understory trees: Port-Orford-cedar and frequently Douglas-fir

Shrubs: frequently western azalea and dwarf tanbark

Forb cover: 6 percent

Grass cover: 4 percent 
CHLA-MCON/QUVA-RHOC

Port-Orford-cedar-Mixed Conifer/Huckleberry Oak-Western Azalea

Elevation range: 2480 to 5180 feet

Aspect: south and southeast

Soils: derived from ultramafic parent material

Overstory: Port-Orford-cedar and Douglas-fir

Understory trees: Port-Orford-cedar and Douglas-fir

Shrubs: frequently western azalea and huckleberry oak

Forb cover: 4 percent

Grass cover: 6 percent

\section{CHLA-ABCO/RHOC-QUVA}

Port-Orford-cedar-White Fir/Western Azalea-Huckleberry Oak

Elevation range: 4810 to 5920 feet

Aspect: northeast and northwest

Soils: some derived from ultramafic parent rock

Overstory: Port-Orford-cedar and white fir, frequently western white pine and Douglasfir

Understory trees: Port-Orford-cedar and white fir

Shrubs: western azalea and frequently huckleberry oak and serviceberry

Forb cover: 9 percent

Grass cover: 3 percent

CHLA-ABCO/LEDA-CASE3

Port-Orford-cedar-White Fir/Sierra Laurel-Bush Chinquapin

Elevation range: 4980 to 5660 feet

Aspect: northwest

Overstory: Port-Orford-cedar and white fir

Understory trees: Port-Orford-cedar and frequently white fir

Shrubs: Sierra laurel and frequently bush chinquapin

Forb cover: 9 percent

Grass cover: 3 percent

CHLA-ABCO/CASE3-RHOC

Port-Orford-cedar-White Fir/Bush Chinquapin-Western Azalea

Elevation range: 4950 to 5750 feet

Aspect: northeast and west

Overstory: Port-Orford-cedar and white fir, frequently Douglas-fir

Understory trees: Port-Orford-cedar and white fir

Shrubs: bush chinquapin and frequently western azalea

Forb cover: low

Grass cover: 3 percent

\section{CHLA-PIMO3/LEGL1/DACA2}

Port-Orford-cedar-Western White Pine/Labrador Tea/California Pitcher Plant

Elevation range: 4300 to 5950 feet

Aspect: northwest and east

Soils: some derived from ultramafic parent rock

Overstory: Port-Orford-cedar, frequently western white pine, Shasta red fir, and white fir Understory trees: Port-Orford-cedar, frequently western white pine and white fir

Shrubs: western Labrador tea

Forb cover: 9 percent

Grass cover: 11 percent 
CHLA-PIMO3/ALSI2

Port-Orford-cedar-Western White Pine/Sitka Alder

Elevation range: 4640 to 5700 feet

Aspect: northwest and northeast

Soils: some derived from ultramafic parent rock

Overstory: Port-Orford-cedar, white fir, western white pine, frequently Douglas-fir

Understory trees: Port-Orford-cedar

Shrubs: Sitka alder

Forb cover: 16 percent

Grass cover: 25 percent

CHLA-PIMO3/VAME

Port-Orford-cedar-Western White Pine/Thinleaf Huckleberry

Elevation range: 4920 to 6000 feet

Aspect: northeast

Overstory: Port-Orford-cedar and western white pine

Understory trees: Port-Orford-cedar, frequently western white pine

Shrubs: thinleaf huckleberry

Forb cover: 15 percent

Grass cover: 2 percent

CHLA-PIMO3//Wet Herb Complex

Port-Orford-cedar-Western White Pine//Wet Herb Complex

Elevation range: 4860 to 6000 feet

Aspect: northeast

Soils: some derived from ultramafic parent rock

Overstory: Port-Orford-cedar, frequently white fir and western white pine

Understory trees: Port-Orford-cedar, frequently white fir

Shrubs: variable

Forb cover: 37 percent

Grass cover: 14 percent

CHLA-PIMO3//Dry Herb Complex

Port-Orford-cedar-Western White Pine/ / Dry Herb Complex

Elevation range: 4860 to 6000 feet

Aspect: north

Soils: some derived from ultramafic parent rock

Overstory: Port-Orford-cedar and western white pine, frequently white fir

Understory trees: Port-Orford-cedar and western white pine, frequently white fir

Shrubs: frequently huckleberry oak and serviceberry

Forb cover: 34 percent

Grass cover: 3 percent

CHLA-TSME/CASE3

Port-Orford-cedar-Mountain Hemlock/Bush Chinquapin

Elevation range: 6080 to 6310 feet

Aspect: northeast

Overstory: Port-Orford-cedar, western white pine, mountain hemlock, and Shasta red fir

Understory trees: Port-Orford-cedar, mountain hemlock, and Shasta red fir, frequently

western white pine

Shrubs: bush chinquapin, huckleberry oak, pinemat manzanita, littleleaf huckleberry

Forb cover: 5 percent

Grass cover: 1 percent 
CHLA-TSME/LEGL1

Port-Orford-cedar-Mountain Hemlock/Labrador Tea

Elevation range: 5700 to 6350 feet

Aspect: northeast and west

Overstory: Port-Orford-cedar and mountain hemlock, frequently Shasta red fir

Understory trees: mountain hemlock, frequently Port-Orford-cedar and Shasta red fir Shrubs: western Labrador tea

Forb cover: 9 percent

Grass cover: 3 percent

CHLA-TSME/LEDA

Port-Orford-cedar-Mountain Hemlock/Sierra Laurel

Elevation range: 4360 to 5180 feet

Aspect: north and northeast

Overstory: Port-Orford-cedar, frequently western white pine, Shasta red fir, and mountain hemlock

Understory trees: Port-Orford-cedar

Shrubs: Sierra laurel

Forb cover: 10 percent

Grass cover: 3 percent

\section{Productivity Indices}

Site productivity among the described plant associations varies considerably, with the lowest productivity in those plant associations found on soils derived from ultramafic parent rock and those on high elevation sites. Table 2.4 shows productivity indices for 26 California plant associations. 
Table 2.4-Productivity indices for 26 California Port-Orford-cedar plant associations (Jimerson and Daniels 1994, Jimerson et al. 2000)

\begin{tabular}{|c|c|c|c|c|}
\hline Plant Association & $\begin{array}{l}\text { Cubic Soft Wood } \\
\text { Volume (ft3/acre) }\end{array}$ & $\begin{array}{l}\text { Dunning Site } \\
\text { Class }\end{array}$ & $\begin{array}{c}\text { Stand } \\
\text { Density } \\
\text { Index }\end{array}$ & $\begin{array}{l}\text { Large Conifers* } \\
\text { per Acre }\end{array}$ \\
\hline CHLA/GASH & 14697 & 1 & 592 & 27 \\
\hline CHLA/RHMA3-GASH & 12498 & 1 & 490 & 25 \\
\hline CHLA/RHOC & 10751 & 3 & 498 & 22 \\
\hline CHLA-ABCO/QUVA & 11867 & 2 & 508 & 25 \\
\hline CHLA-ABCO-PIMO3/QUVA & 11043 & 2 & 540 & 34 \\
\hline CHLA-ABCO/RHOC & 11173 & 3 & 496 & 24 \\
\hline CHLA-ABCO//Herb & 15044 & 1 & 521 & 31 \\
\hline CHLA-ABCO/QUSA2 & 11425 & 1 & 457 & 20 \\
\hline CHLA-ABMAS/QUSA2-VAME & 9766 & 3 & 454 & 19 \\
\hline CHLA-PSME/QUVA & 9821 & 2 & 454 & 22 \\
\hline CHLA-PIMO3/QUVA & 6374 & 5 & 404 & 7 \\
\hline CHLA-LIDE3-ALRH & 8280 & 3 & 459 & 18 \\
\hline CHLA-PSME/CAOC5 & 7217 & 4 & 713 & unknown \\
\hline CHLA-MCON/RHOC-LIDEE & 8055 & 4 & 587 & unknown \\
\hline CHLA-MCON/QUVA-RHOC & 6169 & 4 & 482 & unknown \\
\hline CHLA-ABCO/RHOC-QUVA & 8353 & 4 & 697 & unknown \\
\hline CHLA-ABCO/LEDA-CASE3 & 10017 & 2 & 639 & unknown \\
\hline CHLA-ABCO/CASE3-RHOC & 7045 & 3 & 432 & unknown \\
\hline CHLA-PIMO3/LEGL1/DACA & 29971 & 4 & 772 & unknown \\
\hline CHLA-PIMO3/ALSI2 & 7885 & 4 & 592 & unknown \\
\hline CHLA-PIMO3/VAME & 14832 & 3 & 758 & unknown \\
\hline CHLA-PIMO3//Wet herb & 10389 & 4 & 734 & unknown \\
\hline CHLA-PIMO3//Dry herb & 8380 & 4 & 501 & unknown \\
\hline CHLA-TSME/CASE3 & 11063 & 4 & 1001 & unknown \\
\hline CHLA-TSME/LEGL1 & 7110 & 5 & 655 & unknown \\
\hline CHLA-TSME/LEDA & 9161 & 4 & 652 & unknown \\
\hline
\end{tabular}

* Large conifers are greater than 30 inches diameter at breast height (DBH).

\section{Snags and Down Wood - California}

Snag and down wood information is shown in tables $2.5,2.6$, and 2.7 .

\section{Snags}

Snag analyses for the Port-Orford-cedar Series and the Tanoak-Port-Orford-cedar Subseries were conducted using 139 ecology plots (table 2.8). Densities of large snags ranged from 3.7 to 1.9 per acre. The density of snags was higher in the Port-Orford-cedar Series than in the Tanoak-Port-Orford-cedar Subseries.

Snag species were primarily Douglas-fir or Port-Orford-cedar, with small percentages of 15 other species. Decay classes were well represented in the Port-Orford-cedar Series, with percentages of decay classes 1 through 5 of $15.5,30.9,31.9,15.8$, and 5.9 percent respectively. The Tanoak-Port-Orford-cedar Subseries had fewer decay class 1 snags (4.1 percent). 
Table 2.5-Snag and down wood characteristics for Oregon Port-Orfordcedar plant associations which occur on ultramafic soils (CHLA/QUVA/ XETE, CHLA/LOHI/FESTU)

\begin{tabular}{lcccc}
\hline \multicolumn{1}{c}{ Decay Class } & 6-9 inch & $\begin{array}{c}\text { Diameter* } \\
\text { 10-19 inch }\end{array}$ & 20+inch & Length (feet) \\
\hline Down Wood (n=2) & & & & \\
Pieces/Acre & $0(0)$ & $0(0)$ & $0(0)$ & - \\
Decay Class 1 & $16(23)$ & $18(26)$ & $1(2)$ & 10 \\
Decay Class 2 & $32(46)$ & $2(3)$ & $0(0)$ & $37(24)$ \\
Decay Class 3 & $0(0)$ & $0(0)$ & $0(0)$ & - \\
Decay Class 4 & $0(0)$ & $0(0)$ & $0(0)$ & - \\
Decay Class 5 & & & & \\
Tons/Acre & $0.0(0)$ & $0.0(0)$ & $0.0(0)$ & \\
Decay Class 1 & $0.5(1)$ & $0.0(0)$ & $0.0(0)$ & \\
Decay Class 2 & $2.0(3)$ & $1.0(2)$ & $0.0(0)$ & \\
Decay Class 3 & $0.0(0)$ & $0.0(0)$ & $0.0(0)$ & \\
Decay Class 4 & $0.0(0)$ & $0.0(0)$ & $0.0(0)$ & \\
Decay Class 5 & & & & \\
Snags/Acre (n 3$)$ & $0(0)$ & $0(0)$ & $1(0)$ & \\
Decay Class 1 & $0(0)$ & $0(0)$ & $0(0)$ & \\
Decay Class 2 & $0(0)$ & $4(4)$ & $1(2)$ & \\
Decay Class 3 & $0(0)$ & $0(0)$ & $0(0)$ & \\
Decay Class 4 & $0(0)$ & $0(0)$ & $0(0)$ & \\
Decay Class 5 & &
\end{tabular}

*Size classes for down wood were measured at point of transect intercept and at DBH for snags. Figures given are means and one standard deviation for each, in parenthesis.

Table 2.6-Snag and down wood characteristics for Oregon Port-Orfordcedar plant associations which occur in cool, dry environments (CHLAABCO/BENE2, CHLA-LIDE3/GASH)

\begin{tabular}{lcccc}
\hline \multicolumn{1}{c}{ Decay Class } & 6-9 inch & $\begin{array}{c}\text { Diameter } \\
\text { 10-19 inch }\end{array}$ & 20+inch & Length (feet) \\
\hline Down Wood (n=13) & & & & \\
Pieces/Acre & $0(0)$ & $2(5)$ & $0(0)$ & $29(15)$ \\
Decay Class 1 & $20(32)$ & $8(19)$ & $1(3)$ & $30(28)$ \\
Decay Class 2 & $21(25)$ & $7(13)$ & $11(19)$ & $36(20)$ \\
Decay Class 3 & $22(30)$ & $43(75)$ & $9(17)$ & $27(27)$ \\
Decay Class 4 & $3(8)$ & $9(22)$ & $6(13)$ & $21(13)$ \\
Decay Class 5 & & & & \\
Tons/Acre & $0.0(0)$ & $0.6(2)$ & $0.0(0)$ & \\
Decay Class 1 & $0.8(1)$ & $0.7(2)$ & $4.3(11)$ & \\
Decay Class 2 & $1.5(1)$ & $2.9(5)$ & $16.4(25)$ & \\
Decay Class 3 & $0.8(1)$ & $5.8(10)$ & $12.5(16)$ & \\
Decay Class 4 & $0.1(1)$ & $1.0(2)$ & $5.0(11)$ & \\
Decay Class 5 & & & & \\
Snags/Acre (n 13) & $1(5)$ & $6(11)$ & $1(2)$ & \\
Decay Class 1 & $5(17)$ & $4(6)$ & $1(1)$ & \\
Decay Class 2 & $0(0)$ & $2(4)$ & $1(1)$ & \\
Decay Class 3 & $0(0)$ & $1(3)$ & $2(2)$ & \\
Decay Class 4 & $0(0)$ & $2(4)$ & $0(1)$ & \\
Decay Class 5 & & & \\
\hline
\end{tabular}

"Size classes for down wood were measured at point of transect intercept and at DBH for snags. Figures given are means and one standard deviation for each, in parenthesis. 
Table 2.7-Snag and down wood characteristics for Oregon Port-Orfordcedar plant associations that are codominant with western hemlock (CHLA-TSHE/POMU, CHLA-TSHE/LEDA)

\begin{tabular}{lccc|c}
\hline \multicolumn{1}{c}{ Decay Class } & 6-9 inch & $\begin{array}{c}\text { Diameter* } \\
\text { 10-19 inch }\end{array}$ & 20+ inch & Length (feet) \\
\hline Down Wood (n=13) & & & & \\
Pieces/Acre & $2(5)$ & $5(15)$ & $3(7)$ & $56(51)$ \\
Decay Class 1 & $16(46)$ & $7(9)$ & $4(9)$ & $35(39)$ \\
Decay Class 2 & $23(36)$ & $15(20)$ & $6(9)$ & $30(20)$ \\
Decay Class 3 & $28(74)$ & $21(23)$ & $3(6)$ & $25(16)$ \\
Decay Class 4 & $19(63)$ & $22(34)$ & $2(6)$ & $12(7)$ \\
Decay Class 5 & & & & \\
Tons/Acre & $0.2(1)$ & $0.6(1)$ & $7.5(16)$ & \\
Decay Class 1 & $0.3(1)$ & $2.5(3)$ & $13.6(25)$ & \\
Decay Class 2 & $1.0(2)$ & $3.7(4)$ & $11.9(13)$ & \\
Decay Class 3 & $0.6(1)$ & $4.8(4)$ & $7.3(13)$ & \\
Decay Class 4 & $0.2(1)$ & $1.9(3)$ & $0.6(2)$ & \\
Decay Class 5 & & & & \\
Snags/Acre (n 13) & $2(8)$ & $3(6)$ & $1(2)$ & \\
Decay Class 1 & $1(6)$ & $3(5)$ & $3(5)$ & \\
Decay Class 2 & $0(0)$ & $3(7)$ & $1(2)$ & \\
Decay Class 3 & $0(0)$ & $2(4)$ & $1(2)$ & \\
Decay Class 4 & $2(8)$ & $0(0)$ & $1(1)$ & \\
Decay Class 5 & & &
\end{tabular}

* Size classes for down wood were measured at point of transect intercept and at DBH for snags. Figures given are means and one standard deviation for each, in parenthesis.

Table 2.8-Snag densities (snags per acre) in Port-Orford-cedar Series and Tanoak-Port-Orford-cedar Subseries in California

\begin{tabular}{lrrrr}
\hline Series or Subseries & Number & Size* & Mean & $\begin{array}{c}\text { Standard } \\
\text { Deviation. }\end{array}$ \\
\hline Tanoak-Port-Orford-cedar & 41 & SS & 25.4 & 15.6 \\
& 41 & MS & 2.9 & 4.1 \\
Port-Orford-cedar & 41 & LS & 1.9 & 3.2 \\
& 98 & SS & 25.8 & 17.3 \\
& 98 & MS & 3.2 & 4.2 \\
& 98 & LS & 3.7 & 4.6 \\
\hline
\end{tabular}

"LS=large snag=greater than or equal to 20 " DBH and greater than or equal to 50 feet tall MS=medium snag=greater than or equal to $20^{\prime \prime} \mathrm{DBH}$ and greater than 10 feet tall

$\mathrm{SS}=$ small snag=all snags that do not meet the requirements of medium or large snags

\section{Down Wood}

Analyses of down wood were conducted for the Port-Orford-cedar Series and the Tanoak-Port-Orford-cedar Subseries, using 149 ecology plots (table 2.9). Pieces per acre were greater in the Tanoak-Port-Orford-cedar Subseries than in the Port-Orford-cedar Series. The majority of the down wood was in decay class 3 , and the least was in decay class 1 . The down wood was composed primarily of Douglas-fir and Port-Orford-cedar, with 13 additional species represented at low percentages. Considering all down wood, the number of cavities per piece averaged 0.3 for the Tanoak-Port-Orford-cedar Subseries and 0.6 for the Port-Orford-cedar Series. 
The density of logs is high and the standard deviations large, possibly a reflection of summarization over an entire series or subseries with a wide environmental range. Because of their resistance to decay, dead Port-Orford-cedars would be expected to remain in an ecosystem for a longer period of time than most other conifers when the frequency and extent of wild fires are controlled. The relatively low number of cavities per piece likely reflects the resistance to decay (figs. 2.9 and 2.10).

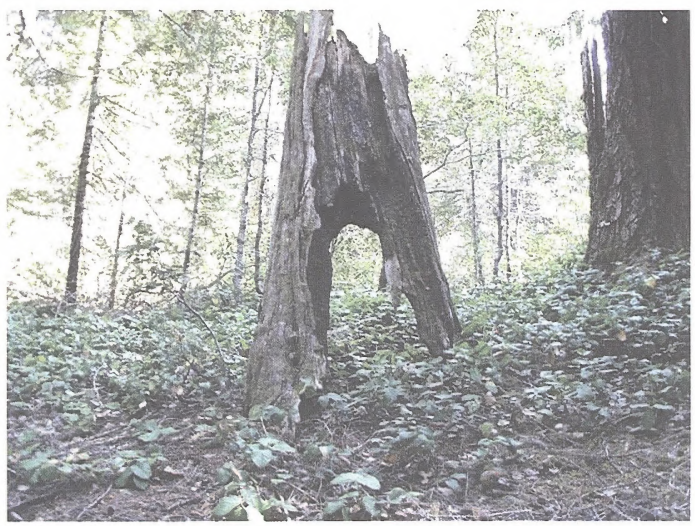

Figure 2.9-Port-Orford-cedar skeleton.

Table 2.9-Down wood densities (pieces per acre) in Port-Orford-cedar Series and Tanoak-Port-Orford-cedar Subseries in California

\begin{tabular}{lrrrr}
\hline Series or Subseries & Number & \multicolumn{1}{c}{ Size* } & Mean & $\begin{array}{c}\text { Standard } \\
\text { Deviation }\end{array}$ \\
\hline Tanoak-Port-Orford-cedar & 49 & $10-14^{\prime \prime}$ & 22.5 & 23.9 \\
& 49 & $15-19^{\prime \prime}$ & 11.5 & 11.1 \\
& 49 & $20-29^{\prime \prime}$ & 10.9 & 13.4 \\
Port-Orford-cedar & 49 & $>30^{\prime \prime}$ & 6.9 & 9.0 \\
& 100 & $10-14^{\prime \prime}$ & 17.2 & 24.2 \\
& 100 & $15-19^{\prime \prime}$ & 11.4 & 12.8 \\
& 100 & $20-29^{\prime \prime}$ & 12.6 & 13.2 \\
& 100 & $>30^{\prime \prime}$ & 4.2 & 6.9 \\
\hline
\end{tabular}

*Size is the measure of the large end diameter. A piece is at least one foot in length. 
Chapter $2-$ Ecological Factors Associated with Port-Orford-Cedar

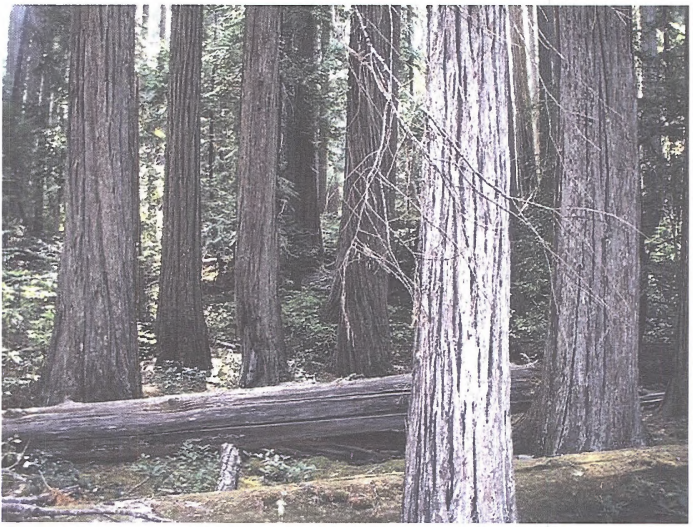

Figure 2.10-Down logs in a Port-Orford-cedar stand

\section{Function in Riparian Systems}

Port-Orford-cedar is an important species in riparian ecosystems (fig. 2.11). Where present, it plays a role in maintenance of water quality. It can provide shade and thereby lower stream temperatures. It may also provide bank stability, and when it dies and falls into the stream, aquatic structure (fig. 2.12). Since Port-Orford-cedar is highly resistant to decay, it may be expected to have a longer residence time in streams than other associated conifers. This may be especially important on serpentine soils where Port-Orford-cedar may be the only, or most abundant, tree species growing on a site.

Figure 2.11-Port-Orford-cedar in a riparian area

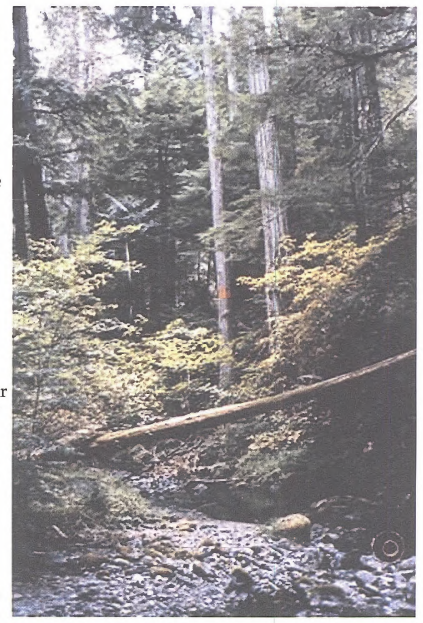




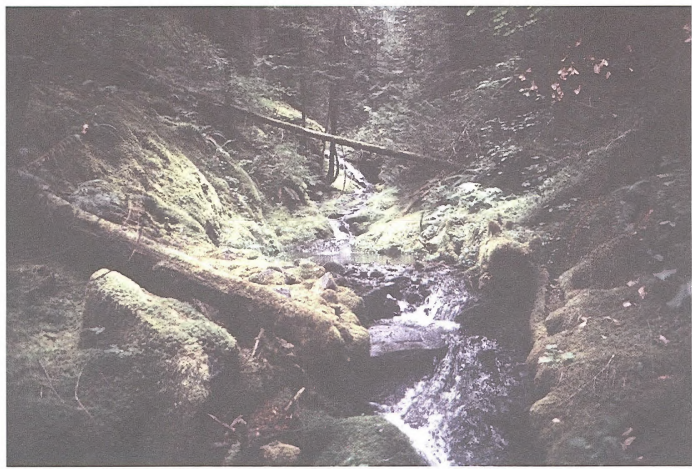

Figure 2.12-Port-Orford-cedar in Pipe Fork Research Natural Area (Williams Watershed, Josephine County), the eastern-most extent of the species in Oregon

\section{Port-Orford-Cedlar Plant Associations with Unique Species and Regional Endemic, Rare or Sensitive Plants}

Port-Orford-cedar plant associations contain unique species and regional endemic, rare or sensitive plants. At least 30 plant species considered sensitive in Forest Service Regions 5 and 6, of special status to the Bureau of Land Management, or rare by the California Native Plant Society (Skinner and Pavlik 1994) or the Oregon Natural Heritage Program (2001) are found in plant associations that contain Port-Orford-cedar. A list of these plants associated with Port-Orford-cedar is shown in Appendix C. Eleven of these rare or sensitive plant species are found only within Port-Orford-cedar plant associations, predominantly on wetland/seep or riparian areas. Plant associations with the highest diversity of rare plants are those that capture microhabitat extremes, from continually wet soils to dry soils in exposed sites. The plant association with the highest number of rare plants is Port-Orford-cedar-California Bay/ Evergreen Huckleberry.

A majority of rare or sensitive plants in Port-Orford-cedar associations occupy habitats with surface (perennial or intermittent) or sub-surface water in the form of spring or seep flow. The unique California pitcher plant (Darlingtonia californica) is the most commonly noted hydrophytic species, followed by California lady's slipper (Cypripedium californicum). These species are endemic to serpentine wetlands (fens, riparian areas, seeps) and are represented in various associations across the range of Port-Orford-cedar.

In comparison to the California pitcher plant and California lady's slipper, there are other wetland species associated with Port-Orford-cedar that are more localized in their distribution. For example, the narrow endemic Western bog violet (Viola primulifolia 
var. occidentalis) occurs in fens and other serpentine wetland habitats in the Gasquet Mountain Ultramafics Subsection in California and the Serpentine Siskiyous Ecoregion in Oregon. The large-flowered rush lily (Hastingsia bracteosa) is a narrow endemic found in the Eight Dollar Mountain area of the Inland Siskiyous Ecoregion of Oregon. It occurs in riparian and wetland settings along with Oregon willow herb (Epilobium oreganum) (Kagan 1990a, 1996). Waldo gentian (Gentiana setigera) is found in the gently sloping serpentine wetlands across the Gasquet Mountain Ultramafics Subsection, Coastal Siskiyous Ecoregion of Oregon, and the Inland Siskiyous Ecoregion of Oregon. Waldo gentian is also found in two, high elevation associations: Port-Orford-cedar-Shasta Red Fir-Brewer's Spruce/Sadler Oak-Huckleberry Oak and Port-Orford-cedar-Shasta Red Fir/Sitka Alder-Sadler Oak. This occurrence of Waldo gentian in montane habitats has been noted by Kagan (1990b) in his management guide for this species. Port-Orfordcedar plant associations in the Lower and Upper Scott Mountain subsections of eastern California support rare plants distinctive to this area including Scott Mountain phacelia (Phacelia dalesiana), showy raillardella (Raillardella pringlei), and crested potentilla (Potentilla cristae).

\section{Literature Cited}

Atzet, T.; White, D.E.; McCrimmon, L.A.; Martinez, P.A.; Fong, P. Reid; Randall, V.D. 1996. Field guide to the forested plant associations of southwest Oregon. R6-NR-ECOLTP-17-96. Portland, OR: U.S. Department of Agriculture, Forest Service, Pacific Northwest Region. 353 p.

Edwards, S.W. 1983. Cenozoic history of Alaskan and Port Orford Chamaecyparis cedars. Berkeley, CA: University of California. 271 p. PhD dissertation.

Jimerson, T.M.; Creasy, R.M. 1991. Variation in Port-Orford-cedar plant communities along environmental gradients in northwest California. In: Harris, R.R.; Erman, D.C.; Kerner, H.M., tech. coords. Proceedings of the symposium on biodiversity of northwestern California. Berkeley, CA: University of California. 122-133 p.

Jimerson, T.M.; Creasy, R.M. 1997. Series, subseries and plant association codes for northwest California. Eureka, CA: U.S. Department of Agriculture, Forest Service, Six Rivers National Forest. 13 p.

Jimerson, T.M.; Daniel, S.L. 1994. A field guide to Port-Orford-cedar plant associations in northwest California. R5-ECOL-TP-002. San Francisco, CA: U.S. Department of Agriculture, Forest Service, Pacific Southwest Region. 154 p.

Jimerson, T.M.; DeNitto, G. 2000. A supplement to: a field guide to Port-Orford-cedar plant associations in northwest California. R5-ECOL-TP-002. San Francisco, CA: U.S. Department of Agriculture, Forest Service, Pacific Southwest Region. 117p.

Jimerson, T.M.; Hoover, L.D.; McGee, E.A.; DeNitto, G.; Creasy, R.M.; Daniel, S.L. 1995. A field guide to serpentine plant associations and sensitive plants in northwest California. R5-ECOL-TP-006. San Francisco, CA: U.S. Department of Agriculture, Forest Service, Pacific Southwest Region. 338 p.

Jimerson, T.M.; McGee, E.A.; DeNitto, G. 2000. A supplement to: a field guide to PortOrford-cedar plant associations in northwest California. R5-ECOL-TP-006. San Francisco, CA: U.S. Department of Agriculture, Forest Service, Pacific Southwest Region. 
Jimerson, T.M.; McGee, E.A.; Jones, D.W.; Svilich, R.J.; Hotalen, E.; DeNitto, G.; Laurent, T.; Tenpas, J.D.; Smith, M.E.; Heffner-McClellan, K.; Daniel, S.L. 1996. A field guide to the tanoak and the Douglas-fir plant associations in northwest California. R5-ECOL-TP-009. San Francisco, CA; U.S. Department of Agriculture, Forest Service, Pacific Southwest Region. 546 p.

Kagan, J. 1990a. Draft species management guide for Epilobium oreganum Greene. Developed for the Siskiyou National Forest and Medford District of the Bureau of Land Management. On file with: U.S. Department of Agriculture, Forest Service, Six Rivers National Forest Supervisor's Office, Eureka, CA.

Kagan, J. 1990b. Draft species management guide for Gentiana setigera Wats. Developed for the Siskiyou National Forest and Medford District of the Bureau of Land Management. On file with: U.S. Department of Agriculture, Forest Service, Six Rivers National Forest Supervisor's Office, Eureka, CA.

Kagan, J. 1996. Draft Conservation Agreement for Hastingsia bracteosa, H. atropurpurea, Gentiana setigera, Epilobium oreganum, and Viola primulifolia var. occidentalis and serpentine Darlingtonia fens and wetlands from southwestern Oregon and northwestern California. On file with: U.S. Department of Agriculture, Forest Service, Six Rivers National Forest Supervisor's Office, Eureka, CA.

McNab, H.W.; Avers, P.E., comps. 1994. Ecological subregions of the United States: section descriptions. Administrative Publication WO-WSA-5. Washington, D.C.: U.S. Department of Agriculture, Forest Service. $267 \mathrm{p}$.

Miles, S.R.; Goudey, C.B., comps. 1997. Ecological subregions of California. R5-EM-TP005. San Francisco, CA: U.S. Department of Agriculture, Forest Service, Pacific Southwest Region. $233 \mathrm{p}$.

Millar, C.I; Delany, D.L.; Westfall, R.D.; Atzet, T.; Jimerson, T.; Greenup, M. 1991. Ecological factors as indicators of genetic diversity in Port-Orford-cedar: applications to genetic conservation. Administrative report. 3 p. On file with: Southwest Oregon Forest Insect and Disease Service Center, J. Herbert Stone Nursery, 2606, Old Stage Road, Central Point, OR 97502.

Oregon Natural Heritage Program. 2001. Rare, threatened and endangered plants and animals of Oregon. Portland, Oregon: Oregon Natural Heritage Program. 94 p.

Skinner, M.W.; Pavlik, B.M., eds. 1994. California Native Plant Society's inventory of rare and endangered vascular plants of California. Sacramento, CA..

U.S. Environmental Protection Agency. 1998. Ecoregions of western Washington and Oregon. Map, 1:1,350,000. Corvallis, OR: National Health and Environmental Effects Research Laboratory. 


\section{Phytophthora lateralis and Other Agents that Damage Port-Orford-Cedar}

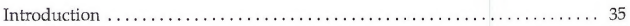

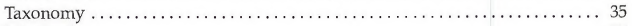

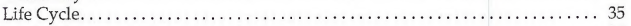

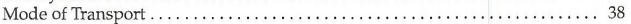

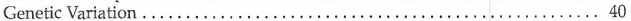

Disease Identification and Detection. . . . . . . . . . . . . . . . . . 41

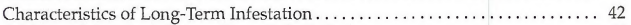

Additional Agents Affecting Port-Orford-Cedar. . . . . . . . . . . . . . 42

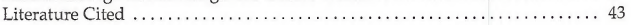


A Range-Wide Assessment of Port-Orford-Cedar on Federal Lands 


\section{Introduction.}

Port-Orford-cedar root disease is caused by the pathogen Phytophthora lateralis. The name Phytophthora means "plant destroyer," and the genus contains many destructive plant pathogens that are distributed throughout the world. Plant diseases often are most damaging when non-native pathogens are introduced into new areas. The Irish potato famine of the 1840 s caused by $P$. infestans (Mont.) de Barry and the current mortality of a large number of plant species in Australia due to P. cinnamomi Rands, provide graphic examples of the destruction that introduced Phytophthora species can cause. Although the origin of $P$. lateralis is unknown, it is likely that the current mortality of Port-Orford-cedar is another example of damage due to such an introduction.

Many investigators believe that $P$. lateralis is an Asian species (Tucker and Milbrath 1942, Zobel et al. 1985) although the pathogen has not been found in Asia. Europe has been suggested as another possible point of origin (Erwin and Ribeiro 1996) and investigators have confirmed the identity of $P$. lateralis isolated from container-grown Port-Orfordcedar seedlings in France. However, it is strongly believed that its presence there resulted from a recent introduction from North America rather than a natural occurrence (Hansen et al. 1999). Another theory is that $P$. lateralis may have originated from some location in North America outside the native range of Port-Orford-cedar, possibly on yellow cedar (Chamaecyparis nootkatensis [Lam.] Sudw.) ${ }^{1}$. However, infected yellow cedars have only been observed under laboratory conditions (Torgeson et al. 1954) and when the species was planted with Port-Orford-cedar on heavily infested experimental sites (McWilliams 2000a). They have not been found in natural stands.

P. lateralis has a narrow host range. Besides Port-Orford-cedar, only Pacific yew (Taxus brevifolia) has been reported to be infected in the wild (DeNitto and Kliejunas 1991, Kliejunas 1994). Pacific yew is much less susceptible to the pathogen than Port-Orfordcedar, and evidence indicates that it mainly becomes infected when in close association with many already-infected cedars (Murray and Hansen 1997). Outside of the native range of Port-Orford-cedar, $P$. lateralis has been identified on ornamental Port-Orfordcedar in British Columbia, Washington, Oregon and northern California. The pathogen has also been reported in other states, as well as other countries, including New Zealand, Germany and France. It has been confirmed only in France (Hansen et al. 1999).

\section{Taxonomy}

P. lateralis is an Ooomycete belonging to the family Pythiaceae. Formerly considered to be true fungi, it is now known that Oomycetes are quite different. Although they are somewhat fungus-like, Oomycetes are more closely related to biflagellate algae than to fungi (Beakes 1987, Dick 1982). It is now generally accepted that Oomycetes constitute a separate kingdom from the fungi (Cavalier-Smith 1986, Dick 1995, Erwin and Ribeiro 1996, Parker 1982).

\section{Life Cycle}

All Phytophthoras exist primarily as hyphae, or thin threads of fungus-like material adjacent to and within their host. Aggregations of hyphae are known as mycelia. Mycelia, if fragmented or transported along with pieces of host plant, can serve to move the pathogen to new locations. Mycelia are somewhat fragile and die when exposed to drying conditions. Several spore types form as specialized structures attached to Phytophthora mycelia.

${ }^{1}$ Roth, L.F.; Goheen, D.J. 1977. Personal communication. Roth, retired, Plant Pathologist, Oregon State University. Goheen, Pathologist, USDA 
Most Phytophthoras have four spore types, with different environmental tolerances and functions: zoosporangia, zoospores, chlamydospores, and oospores (fig. 3.1). Zoosporangia (often simply called sporangia) are thin-walled sacs that form at the ends of mycelial branches. In some species, these sporangia can break off (caducous sporangia) and be readily spread overland by water or wind to infect new hosts. Although there are reports of $P$. lateralis infecting Port-Orford-cedar foliage via rain splash on rare occasions (Roth et al. 1957), there appears to be little evidence that the pathogen produces caducous sporangia in nature. Caducous sporangia are produced by $P$. lateralis in culture under some conditions, but the significance of this for field situations is unclear. ${ }^{2}$

Sporangia can also remain attached to the original mycelium and the contents can differentiate into zoospores. When mature, and generally in the presence of free water, the zoospores are released (fig. 3.2). Zoospores lack cell walls, are very delicate and have two flagella. They can swim for several hours before forming cysts, but can only travel an inch or two in standing water (Carlile 1983). Zoospores also have the ability to detect compounds released by a host and swim in the direction of the host. Upon contact with a host rootlet, the zoospore will attach itself and germinate. If a host rootlet is not found, other surfaces are contacted, or agitation occurs, a zoospore will form a cyst. When encysted, it can be carried considerable distances in running water. In contact with a host, the cyst can germinate and form a mycelium that infects the host, or it can form another sporangium and release more zoospores. Infection by sporangia and zoospores of $P$. lateralis occurs primarily through the succulent growing tips of small Port-Orford-cedar rootlets that occur in the duff or at shallow depths in soil. Port-Orfordcedar produces a multitude of fine rootlets in these strata (Gordon and Roth 1976, Zobel

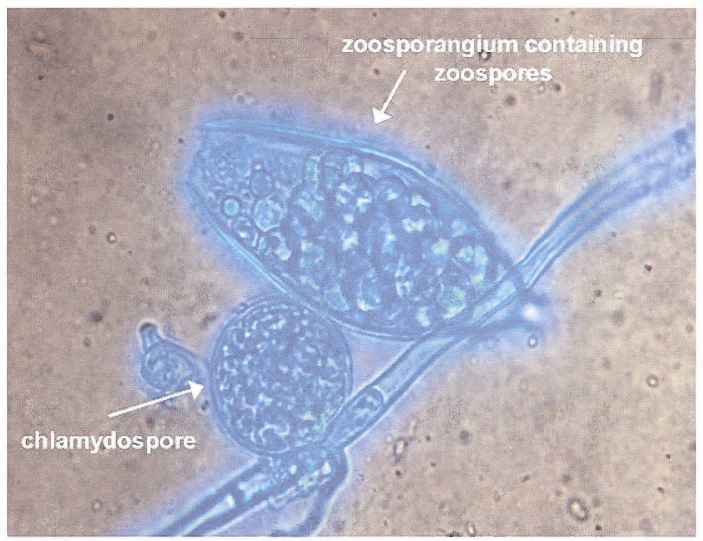

Figure 3.1-Spore types of Phytophthora lateralis

\footnotetext{
${ }^{2}$ Hansen, E.M. 1998. Personal communication. Professor of Forest Pathology, Oregon State University, Department of Botany and Plant Pathology, Corvallis, OR.
} 
et al. 1985). Sporangial development and zoospore production are favored by cool, moist conditions and are optimal at temperatures between $50^{\circ} \mathrm{F}$ and $68^{\circ} \mathrm{F}$ (Trione 1974). Under favorable cool, wet conditions, $P$. lateralis populations can increase rapidly in areas where hosts are numerous because of the rapid and continuing production of flagellate zoospores and other spore types.

Chlamydospores are thick-walled vegetative spores (fig. 3.1). In P. lateralis cultures, they form abundantly and are laterally attached to the mycelium. Chlamydospores are more resistant to drying and temperature extremes than mycelia or sporangia. They can germinate directly and form infective mycelia or, in the presence of water, they can form sporangia and release zoospores. Ostrofsky et al. (1977) showed that, under laboratory conditions, $P$. lateralis populations detected by baiting ${ }^{3}$ decreased substantially when unfavorably warm, dry conditions typical of summer months in the range of Port-Orfordcedar occurred. However, the pathogen survived at a reduced level as chlamydospores in organic matter, especially in small roots on infected trees and fragments of roots in the surrounding soil. Hansen and Hamm (1996) have demonstrated that P. lateralis can survive in infected Port-Orford-cedar roots and root fragments for at least seven years under favorable conditions. P. lateralis chlamydospores are incapable of direct movement, but their structure provides protection during passive movement in infected roots or organic material in soil and mud.

The fourth spore type produced by Phytophthora species is the oospore, which is a sexual spore. $P$. lateralis is homothallic, meaning a mycelium resulting from a single zoospore can form oospores without another mating type being present. The oospore is the spore stage most resistant to drying and environmental extremes, and can survive for many years before germinating. As with the other spore stages, an oospore can germinate

Figure 3.2-Phytophthora sporangia containing zoospores

\footnotetext{
${ }^{3}$ Baiting is a type of bio-assay that uses Port-Orford-cedar seedlings to determine the presence of Phytophthora lateralis. Non-resistant PortOrford-cedar seedlings are planted in soil or placed in streams where P. lateralis is suspected to occur. After an exposure period of four to eight weeks, the seedlings are recollected and examined for cambial stain, a diagnostic symptom of infection by $P$. lateralis. To confirm the diagnosis, root tissue from a subsample of seedlings is cultured on a selective media and examined under a microscope for the sporangia characteristic of $P$. lateralis.
} 
directly to form a mycelium, or produce sporangia and zoospores. Oospores are rarely seen in cultures of $P$. lateralis unless a special medium is used, and their importance in the life cycle of this species in the forest is unknown.

\section{Mode of Transport}

Long distance spread of $P$. lateralis results from moving infected seedlings or infested soil into previously disease-free sites. Humans have been the primary vectors of the pathogen. Major spread in forests has occurred via earth movement in road construction, road maintenance, mining, logging, and traffic flow on forest roads (Kliejunas 1994, Roth et al. 1957, Roth et al. 1972) (fig. 3.3). In general, the pathogen has not spread into areas where a lack of access has prevented human activity. Movement of the pathogen in organic matter in soil clinging to the feet of elk, cattle, and humans also is known to occur but on a much more localized basis than that associated with vehicles (Harvey et al. 1985, Kliejunas 1994, Kliejunas and Adams 1980, Roth et al. 1972). Spread of P. lateralis occurs primarily in the late fall, winter, and early spring when the cool, moist environmental conditions favorable for the pathogen prevail. Unless there are unusually wet conditions, little or no spread occurs in the hot, dry summer months.

Once infested soil is deposited along a road or trail, $P$. lateralis can travel down slope in water. In order to facilitate further spread, this relatively small amount of inoculum must encounter a new Port-Orford-cedar host in the immediate area. Port-Orford-cedar is not usually infected more than 40 feet downslope from roads or trails, except where streams, culverts, wet areas or other roads are present to facilitate further dispersal (Goheen et

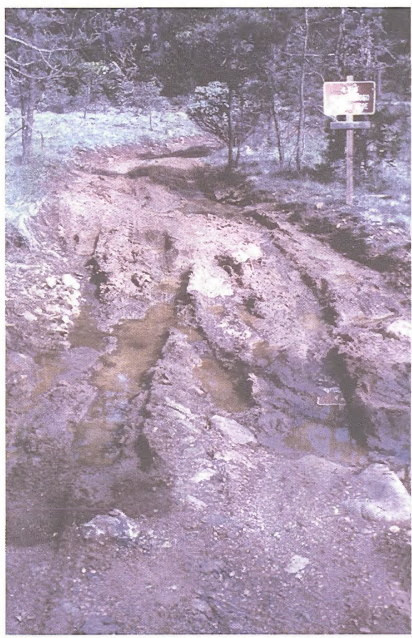
al. 1986). Infection of a new host in the immediate vicinity of the road or trailside results in the production of numerous additional zoospores and chlamydospores, increasing the likelihood of further downslope disease spread (Goheen et al. 1986, Hansen 1993). Preliminary study results show that PortOrford-cedar can be infected at least 164 feet down a stream below a road crossing (Jules and Kauffman, 1999). Anecdotal evidence implies that disease spread may be much further.

While swimming zoospores may travel downstream in freely moving water, spread of the disease over longer distances is most likely accomplished by the more resilient chlamydospores and encysted zoospores. If by chance these spores encounter

Figure 3.3-Favorable conditions for spreading Phytophthora lateralis by vehicles 
a new Port-Orford-cedar host, they may germinate and form mycelium that initiates infection. Alternately, chlamydospores and encysted zoospores may germinate to produce additional sporangia and swimming zoospores. If released near a new host, these zoospores may swim the remaining short distance to initiate infection.

In virtually all cases, infection of Port-Orford-cedar by $P$. lateralis occurs in areas where obvious avenues for water-borne spore dispersal exist. Infection is dependent on the presence of free water in the immediate vicinity of susceptible tree roots (fig. 3.4). High risk areas for infestation include stream courses, drainages, low lying areas downslope from existing centers of infestation, and areas below roads and trails where inoculum is introduced. The position of previously disease-killed cedars along the length of the stream channel is not necessarily a good predictor of the sequence of infection, as trees upstream are not always infected earlier than those located further downstream. However, it has been found that trees nearer to the center of the stream channel become infected earlier than those growing farther away from the stream (Kaufmann and Jules 1999). The spread of disease within a stream appears to follow a classic epidemic pattern, with levels low in the first years, increasing to a maximum number of new infections, and then decreasing again in subsequent years (Kaufmann and Jules 1999).

Topography has a considerable influence on the spread of the pathogen. Steep slopes, dissected by drainages, can quickly channel infested water into streams whereas cross slope spread is more restricted. On broad slopes or flat areas, infested water may spread out over larger areas and move more slowly. Because they are easily flooded, concave areas with Port-Orford-cedar are very vulnerable to infestation. Cedar on convex slopes, on the other hand, exhibits limited vulnerability. Port-Orford-cedar growing on sites or micro sites that are unfavorable for spread of the pathogen often escape infection, even in areas where infected trees are nearby. Tree-to-tree spread of $P$. lateralis via mycelial growth across root contact does occur (Gordon and Roth 1976) but is considered to be much less significant in the epidemiology of the pathogen than spread by spores in free water.

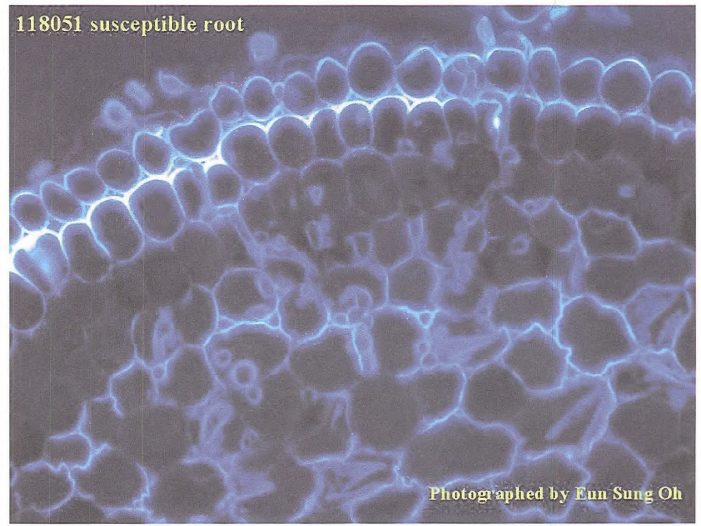

Figure 3.4-Phytophthora lateralis infected root 


\section{Genetic Variation}

Relatively few studies have focused on the genetics of $P$. lateralis; however, the question of variation in isolates of the pathogen is an important one. It is necessary to know the range of variability in pathogenicity and virulence among isolates so that appropriate resistance can be incorporated into the ongoing Port-Orford-cedar breeding program. It is also necessary to know the variation in virulence so that appropriate isolates can be used in testing for resistance. The amount of genetic variation among isolates will offer important data for determining population structure of $P$. lateralis and whether the pathogen exhibits a simple structure compatible with the idea of introduction. If genetic information is consistent with the idea that this pathogen was introduced to North America, then it should support efforts to determine its origin, and give some basis for comparison if that location is ever found.

Some studies examining spore production, growth, lesion length produced on inoculated hosts, uniformity of isozyme profiles, and DNA fingerprinting have been conducted on P. lateralis. In a comparison of ten isolates from Oregon, nine isolates were found similar in sporangia production and all ten produced oospores equally well. The isolates, however, varied in chlamydospore production (Trione 1959). In 1991, a study of 11 isolates from Oregon and California showed identical isozyme banding patterns (Mills et al. 1991). A study in 1990 demonstrated the lack of variability among 23 isolates collected from throughout the range of Port-Orford-cedar (Hansen unpublished). Only one isolate grew more slowly than the others. There were significant, but unrepeatable, differences in zoospore production but no differences among total protein and isozyme bands. The one isolate that grew more slowly also caused significantly shorter lesions in inoculation tests. The authors suggest that a simple difference in growth rate could produce differences in zoospore production and pathogenicity. A recent study compared growth rates, virulence, and DNA fingerprints among 13 isolates of $P$. lateralis collected from Canada to California (McWilliams 2000a , b). Isolates were grown on two types of agar and were from three hosts: naturally infected Port-Orford-cedar and Pacific yew, and experimentally infected yellow cedar. To examine any differences in virulence, three inoculation methods were used. One method involved inserting a block of mycelium under the bark of rooted cuttings, a second method involved inoculating detached stems with zoospores, and a third method involved inoculating intact root systems with zoospores. Results showed some differences in growth rates but nearly identical DNA banding patterns. One isolate, of the 13 used, produced significantly shorter lesions in the inoculation experiment. There were no differences in the lesion lengths of other isolates.

The near uniformity of DNA fingerprints and isozyme profiles in the studies previously described suggests limited genetic variability in the $P$. lateralis found in the native range of Port-Orford-cedar. The genetic uniformity found in P. lateralis, combined with the extreme susceptibility of the host, provides evidence that this pathogen was probably introduced into the Port-Orford-cedar native range. Given the genetic uniformity of this pathogen, it is interesting to note the significant difference in virulence found in one isolate in the 2000 study. This difference may be due to diminished virulence attributable to lengthy storage conditions or other factors. The differences in lesion length when roots and shoots are exposed to zoospore inoculum may be due to differences in the susceptibility of roots and stems, differences in host mechanisms to limit growth in the different plant tissues, or because of variations in the inoculation technique or number of zoospores in the inoculum.

The lack of genetic variability in P. lateralis suggests that if Port-Orford-cedar trees resistant to the pathogen can be found or developed through a breeding program, the resistance should have a strong likelihood of persisting over time. 
There remain unanswered questions about the biology and epidemiology of $P$. lateralis. The role of the occasionally caducous sporangia in long distance spread along watercourses may be important. Oospores may form more readily in the forest than in the laboratory, and the role of these oospores in long-term survival is not known. The prevalence of less virulent isolates is not known. It is interesting to speculate about the isolates that are indistinguishable using DNA fingerprints, isozymes, or total proteins, but exhibit differences in virulence. It is possible that passage through certain hosts, storage conditions, or virus infections could have led to reduced virulence. Fundamental questions remain concerning the origin of the species, variability in the native range, and resistance mechanisms of the native host.

\section{Disease Identification and Detection}

Port-Orford-cedar root disease is identified in the field by: (a) the rapid death of individual hosts, (b) the almost exclusive occurrence on Port-Orford-cedar, (c) the characteristic distribution of the disease in sites favorable for the water-borne spread of the pathogen, and (d) the distinctive symptoms that $P$. lateralis causes on infected trees (Zobel et al. 1985). Crowns of infected trees first fade slightly or appear somewhat wilted. They subsequently change color from their normal green or blue green to yellowish gold, bronze, reddish brown, and finally dull brown. Symptoms manifest themselves rapidly and tree death occurs quickly in seedlings and saplings during periods when warm, dry weather develops after infection. With such trees, the entire progression of symptoms may occur within two to three weeks. Large Port-Orford-cedar die much more slowly, declining over periods of one to four years. Signs of infection in Port-Orford-cedar roots include loss of luster of root tips, water-soaking of rootlets, and death and decay of roots. The bark on main roots may darken or turn somewhat purplish. Mycelia of the pathogen grow in the inner bark and cambium of hosts, colonizing and killing much of the root systems, and ultimately girdling the main stems in the lower boles. In live Port-Orfordcedar exhibiting crown symptoms, a distinctive cinnamon-colored stain that abuts abruptly against healthy creamcolored inner bark is apparent at or above the root collar (fig. 3.5). This stain, which can be followed down into the roots, is considered diagnostic of infection by $P$. lateralis. Once a PortOrford-cedar dies, the inner bark of the entire bole turns brown, and it is no longer possible to use presence of staining as an identification tool.

There are several additional techniques available for detecting the presence of $P$. lateralis. The pathogen can be isolated from symptomatic and recently killed trees on a selective medium such as cornmeal agar amended with pimaricin, rifampicin, and ampicilin (CARP medium). Currently, Port-Orford-cedar seedlings

Figure 3.5-Cambial stain on infected Port-Orford-cedar

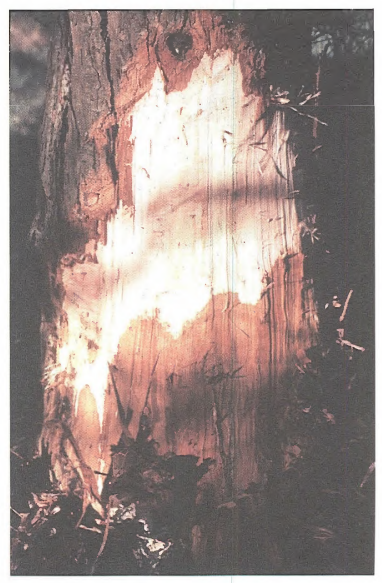


are used as baits to determine occurrence and quantity of P. lateralis inoculum in soil and water. The presence of $P$. lateralis is confirmed by isolation from bait seedlings onto CARP medium. A soil assessment method using tree branchlets floated over water amended with hymexazol and transferred to CARP medium was also developed by Hamm and Hansen (1984).

A Polymerase Chain Reaction (PCR) DNA test for P. lateralis is currently being designed, developed and tested at Oregon State University (Winton and Hansen 2000, Winton and Hansen 2001). Early results of trials with this method demonstrate that it can be used to identify P. lateralis from both root and stem tissues. Early results indicate this test may become a more sensitive and accurate test than traditional culturing techniques and can reduce by several days the time needed to identify the pathogen. This technique can be performed upon soils by processing foliage baits and may be usable for detecting $P$. lateralis in infested stream water.

\section{Characteristics of Long-Term Infestation}

Port-Orford-cedar root disease centers consist of variable-sized groups of dead and dying trees. Port-Orford-cedar is a prolific seed producer, and new regeneration of the host often becomes established in infestation centers. This regeneration usually becomes infected, in turn, resulting in chronic disease expression. Because of its ability to reproduce at an early age, produce large numbers of seeds, and because many trees that occur on sites with characteristics unfavorable for the spread of $P$. lateralis completely escape infection, Port-Orford-cedar has not yet been eliminated by the pathogen in any significant portion of its range. Nonetheless, $P$. lateralis has caused substantial amounts of mortality on individual infested sites and has greatly influenced stand structure by killing large trees and preventing small trees from attaining large size. The disease can greatly influence the ecological roles of Port-Orford-cedar, particularly in streamside areas where conditions are favorable for spread of the pathogen.

\section{Additional Agents Affecting Port-Orford-cedar}

Except for P. lateralis, Port-Orford-cedar has few significant enemies. Cedar bark beetles (Phloeosinus spp., especially P. sequoiae Hopkins) infect some trees, but usually only trees with much reduced vigor. They rarely kill trees by themselves, but commonly administer the coup de grace to Port-Orford-cedar infected by P. lateralis. Port-Orford-cedar is a remarkably decay resistant species. Several decay fungi, including Phellinus pini (Thore: Fr.) Pilat and Heterobasidion annosum (Fr.) Bref., have been found on Port-Orford-cedar, but are uncommon and appear to have little impact. Grey mold (caused by Botrytis cinerea Pers.: Fr.), cypress canker (caused by Seridium cardinale (W. Wagner) Sutton \& I. Gibson), and root disease (caused by P. cinnamomi) are problems in nurseries but rarely cause widespread devastation. Black bears (Ursus americanus Pallas) often peel bark and feed on the cambium of trees in early spring, causing extensive local damage to PortOrford-cedar. Port-Orford-cedars, especially those occurring on drier sites, may succumb to drought during periods of protracted dry weather. Drought may also predispose cedars to attack by bark beetles or woodborers. 


\section{Literature Cited}

Beakes, G.W. 1987. Oomycete phylogeny; ultrastructural perspectives. In: Rayner, A.D.M.; Braiser, C.M.; Moore, D., eds. Evolutionary biology of the fungi. Cambridge University Press: $405-421$.

Carlile, M.J. 1983. Motility, taxis, and tropism in Phytophthora. In: Erwin, D.C.; BartnickiGarcia, S.; Tsao, P.H., eds. Phytophthora: its biology, taxonomy, ecology, and pathology. St. Paul, MN: American Phytopathological Society: 95-107.

Cavalier-Smith, T. 1986. The kingdom Chromista: origin and systematics. In: Round, I.; Chapman, D.J., eds. Progress in phycological research. Bristol, England: Biopress. Vol. 4. $481 \mathrm{p}$.

DeNitto, G.; Kliejunas, J.T. 1991. First report of Phytophthora lateralis on pacific yew [Abstract]. Plant Disease 75:968.

Dick, M.W. 1982. Oomycetes. In: Parker, I.S.P., ed. Synopsis and classification of living organisms. New York: McGraw Hill Book Co.: 179-180.

Dick, M.W. 1995. Sexual reproduction in the Peronosporales (chromistan fungi). Canadian Journal of Botany 73:5712-5724.

Erwin, D.C.; Ribeiro, O.K. 1996. Phytophthora diseases worldwide. Saint Paul, MN: American Phytopathological Society. 562 p.

Goheen, E.M.; Cobb, D.F.; Forry, K. 1986. Roadside surveys for Port-Orford-cedar root disease on the Powers Ranger District, Siskiyou National Forest. Portland, OR: U.S. Department of Agriculture, Forest Service, Pacific Northwest Region. Administrative report. On file with: Southwest Oregon Insect and Disease Service Center, J. Herbert Stone Nursery, 2606, Old Stage Road, Central Point, OR 97502. 19p.

Gordon, D.E.; Roth, L.F. 1976. Root grafting in Port-Orford-cedar : an infection route for root rot. Forest Science 22:276-278.

Hamm, P.B.; Hansen, E.M. 1984. Improved method for isolating Phytophthora lateralis from soil. Plant Disease 68:517-519.

Hansen, E.M. 1993. Roadside surveys for Port-Orford-cedar root disease on the Powers Ranger District, Siskiyou National Forest. Corvallis, OR: Oregon State University. Unpublished report. 17p. On file with: Southwest Oregon Forest Insect and Disease Service Center, J. Herbert Stone Nursery, 2606, Old Stage Road, Central Point, OR 97502.

Hansen, E.M.; Hamm, P.B. 1996. Survival of Phytophthora lateralis in infected roots of PortOrford-cedar. Plant Disease 80:1075-1078.

Hansen, E.M.; Streito, J.C.; Delator, C. 1999. First confirmation of Phytophthora lateralis in Europe. Plant Disease 83:587.

Harvey, R.D.; Hadfield, J.H.; Greenup, M. 1985. Port-Orford-cedar root rot on the Siskiyou National Forest in Oregon. Portland, OR: U.S. Department of Agriculture, Forest Service, Pacific Northwest Region. Administrative report. 17 p. On file with: Southwest Oregon Forest Insect and Disease Service Center, J. Herbert Stone Nursery, 2606, Old Stage Road, Central Point, OR 97502. 
Jules, E.; Kaufmann, M. July, 1999. Reconstructing historical spread of Phytophthora lateralis. I: Patterns of infection between populations of Port-Orford-cedar. Presentation at The Ecology and Pathology of Port-Orford-cedar: A Symposium. Sponsored by U.S. Department of Agriculture and U.S. Department of the Interior, Gold Beach, OR.

Kaufmann, M.; Jules, E. July, 1999. Reconstructing historical spread of Phytophthora lateralis. II. Infection dynamics along a stream population of Port-Orford-cedar. Presentation at The Ecology and Pathology of Port-Orford-cedar: A Symposium. Sponsored by U.S. Department of Agriculture and U.S. Department of the Interior, Gold Beach, OR.

Kliejunas, J.T. 1994. Port-Orford-cedar root disease. Fremontia 22:3-11.

Kliejunas, J.T;; Adams, D.H. 1980. An evaluation of Phytophthora root rot of Port-Orfordcedar in California. Forest Pest Management Report No. 80-1. San Francisco, CA: U.S. Department of Agriculture, Forest Service, Region 5. 16 p.

McWilliams, M.G. 2000a. Port-Orford-cedar and Phytophthora lateralis: grafting and heritability of resistance in the host and variation in the pathogen. Corvallis, OR: Oregon State University. PhD thesis.

McWilliams, M.G. 2000b. Variation in Phytophthora lateralis. In: Hansen and Sutton, eds. Proceedings of the first international meeting on Phytophthoras in forest and wildland ecosystems, IUFRO working party 7.02.09. Corvallis, OR: Oregon State University, Forest Research Laboratory: 50-55.

Mills, S.D.; Foster, H.; Coffey, M.D. 1991. Taxonomic structure of Phytophthora cryptogea and $P$. drechsleri based on isozyme and mitochondrial DNA analyses. Mycological Research 95:31-48.

Murray, M.S.; Hansen, E.M. 1997. Susceptibility of pacific yew to Phytophthora lateralis. Plant Disease 81:1400-1404.

Ostrofsky, W.D.; Pratt, R.G.; Roth, L.F. 1977. Detection of Phytophthora lateralis in soil organic matter and factors that affect its survival. Phytopathology 67:79-84.

Parker, I.S.P., ed. 1982. Synopsis and classification of living organisms. New York: McGraw-Hill Book Co. 1166 p.

Roth, L.F.; Bynum, H.H.; Nelson, E.E. 1972. Phytophthora root rot of Port-Orford-cedar. Forest Pest Leaflet 131. Portland, OR: U.S. Department of Agriculture, Forest Service, Pacific Northwest Forest and Range Experiment Station. 7 p.

Roth, L.F.; Trione, E.J.; Ruhmann, W.H. 1957. Phytophthora induced root rot of native PortOrford-cedar. Journal of Forestry. 55:294-298.

Torgeson, D.C.; Young, R.A.; Milbrath, J.A. 1954. Phytophthora root rot diseases of Lawson cypress and other ornamentals. Corvallis, OR: Oregon State College, Agricultural Experiment Station. Bulletin 537. 18 p.

Trione, E.J. 1959. The pathology of Phytophthora lateralis on native Chamaecyparis lawsoniana. Phytopathology 49:306-310.

Trione, E.J. 1974. Sporulation and germination of Phytophthora lateralis. Phytopathology 64:1531-1533. 
Tucker, C.M.; Milbrath, J.A. 1942. Root rot of Chamaecyparis caused by a species of Phytophthora. Mycologia. 34:94-103.

Winton, L.M.; Hansen, E.M. 2000. PCR diagnosis of Phytophthora lateralis. In: Hansen and Sutton, eds. Proceedings of the first international meeting on Phytophthoras in forest and wildland ecosystems, IUFRO working party 7.02.09. Corvallis, OR: Oregon State University, Forest Research Laboratory: 148-149.

Winton, L.M.; Hansen, E.M. 2001. Molecular diagnosis of Phytophthora lateralis in trees, water, and foliage baits using multiplex polymerase chain reaction. Forest Pathology 31: 275-283.

Zobel, D.B.; Roth, L.F; Hawk, G.M. 1985. Ecology, pathology, and management of PortOrford-cedar (Chamaecyparis lawsoniana). General Technical Report PNW-184. Portland, OR: U.S. Department of Agriculture, Forest Service Pacific Northwest Forest and Range Experiment Station. 161 p. 


\section{Chapter 4 Impacts of Phytophthora lateralis on Port-Orford-Cedar}

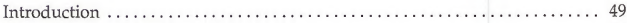

Extent of Infestation. . . . . . . . . . . . . . . . . . . . . . .

Geographic Information System Mapping Methodologies.............. 51

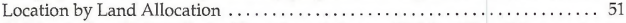

California Port-Orford-Cedar Plant Associations with More Than 10 percent

P. lateralis Infestation. . . . . . . . . . . . . . . . . . . . . . . . 52

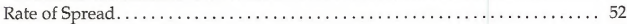

Status of Infestation Relative to Roads . . . . . . . . . . . . . . . . 57

Landscape Level Impacts of Port-Orford-Cedar Root Disease . . . . . . . . . . 59

Coquille River Falls Research National Area ................. 59

Powers Roads ........................................ 59

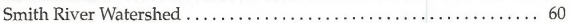

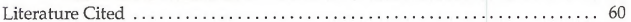




\section{Introduction}

Much of the impetus to undertake a range-wide assessment of Port-Orford-cedar came from questions on the extent of infection caused by Phytophthora lateralis, and the impacts of the pathogen on Port-Orford-cedar as a species.

\section{Extent of Infestation}

Approximately nine percent of mapped Forest Service and Bureau of Land Management (BLM) Port-Orford-cedar land in Oregon and California is mapped as infested with P. lateralis and has dead and dying Port-Orford-cedar trees ${ }^{4}$ (figs. 4.1 and 4.2).

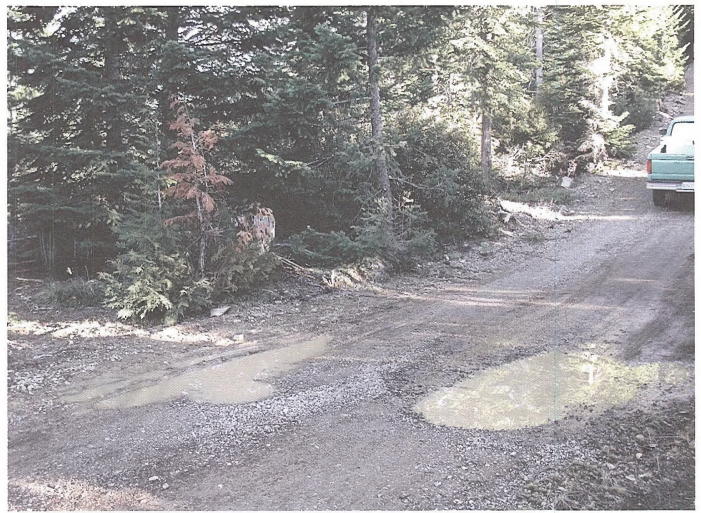

Figure 4.1-Port-Orford-cedar killed by Phytophthora lateralis. Note proximity to road and poorly drained spot where water has puddled. 


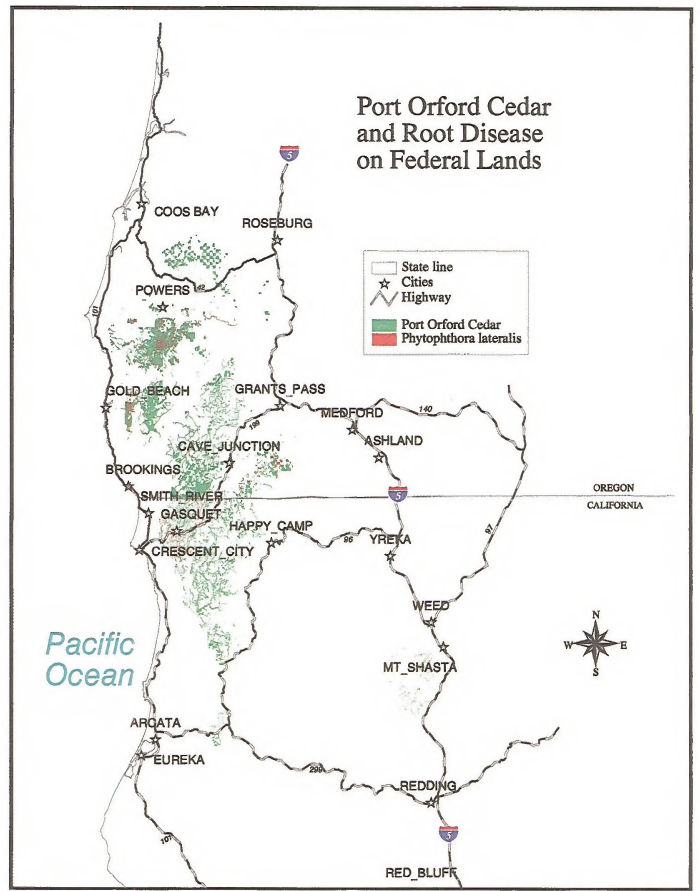

Figure 4.2-Healthy and infected Port-Orford-cedar on federal lands

An analysis ${ }^{5}$ from northern California, the most heavily infested area on federal lands, shows most of the infestation is in three, fifth-field watersheds. The South Fork Smith River is 37 percent infested, the Middle Fork Smith River, 34 percent infested, and the Lower Smith River is 21 percent infested. Within Oregon, the most infested area is in the Siskiyou Mountains ecoregion where the Williams Creek watershed is 15 percent infested.

\footnotetext{
${ }^{5}$ GIS analysis designed by Kirk Casavan and Don Rose; conducted by Debra Kroeger; based on the Port-Orford-cedar Range-wide Geographic Information Systems Layer on Federal Lands.
} 


\section{Geographic Information System Mapping Methodologies}

Mapping of $P$. lateralis infestations has been accomplished in a variety of ways. On the Siskiyou National Forest, roadside surveys were first conducted in 1964 and continue to today. Visual observations of the occurrence and estimated locations of dead PortOrford-cedar were noted and entered into the Geographic Information System (GIS). In 2002, the Powers Ranger District of the Siskiyou National Forest also used photo interpretation and field verification to further refine District diseased and healthy PortOrford-cedar locations. National Forests in California utilized ecological mapping techniques for estimating the occurrence of disease. The BLM, using roadside surveys and aerial photo interpretation, mapped Port-Orford-cedar root disease locales and compiled this information for Oregon into GIS by 1998. Since 1998, the Coos Bay, Medford and Roseburg Districts have made several subsequent updates, using these survey techniques as well as integrating current observations made from on-going data collection, such as from silvicultural stand exams and timber sale cruise data.

Mapping locations of healthy Port-Orford-cedar is more difficult because it is more difficult to see, both on the ground as well as in aerial photographs. The Forest Service and BLM have used general roadside surveys to estimate where healthy PortOrford-cedar grows. The BLM defined the intersection of uninfested road segments with individual timber stands (based upon the Forest Operations Inventory) as the approximate mapped locations of healthy Port-Orford-cedar. National Forests in California performed field work involving ecological mapping to approximate the locales of healthy Port-Orford-cedar.

The resulting comparisons of diseased and healthy acres of Port-Orford-cedar produced the range-wide estimate of nine percent infestation of Port-Orford-cedar.

\section{Location by Land Allocation}

Infestation is not restricted to any land allocation (table 4.1).

Eighty percent of the range of Port-Orford-cedar on federal lands is in allocations that are unlikely to be harvested (administratively withdrawn, late successional reserve, and congressional withdrawals). Of particular interest, because of its ecological role, is the health of Port-Orford-cedar in riparian areas. Riparian areas, as defined by National

Table 4.1-Approximate percentages of acres in different federal land allocations over the range of Port-Orford-cedar and percentage of those acres inhabited by Port-Orford-cedar that are infested by $P$. lateralis

\begin{tabular}{lcc}
\hline Allocation & Allocation Acres (percent) & Diseased Acres (percent) \\
\hline Late Successional Reserve & 58 & 9 \\
Matrix/Riparian & 19 & 8 \\
Congresionally Withdrawn & 17 & 6 \\
Administratively Withdrawn & 5 & 4 \\
Adaptive Management Area & 1 & 14 \\
\hline
\end{tabular}


Forests and BLM Districts, make up about 40 percent of the area within the range of PortOrford-cedar. Within these riparian areas, a relatively high percentage of the area, about

13 percent, is infested. Outside of the riparian areas, only 5 percent of the area is infested.

\section{California Port-Orford-Cedar Plant Associations with More than 10 percent $P$. lateralis Infestation}

An analysis from California shows, at least in the California portion of the range of Port-Orford-cedar, most of the infestation is in riparian areas (table 4.2). Seven plant associations have at least 10 percent of their area infested.

\section{Rate of Spread}

Rate of spread of $P$. lateralis over the range of Port-Orford-cedar has been highly variable from watershed to watershed. There is no determinable rate of spread which is applicable range-wide. In some drainages, the rate of spread has been relatively rapid.

Data were collected during the infestation of the Smith River drainage in California from 1980 through 1999 (figs. 4.3 through 4.6). In 1980, infestation was present at about nine small, isolated sites. Three years later, the sites had expanded in size and new sites were evident. With 10 additional years, the infestation was almost continuous along several waterways, and by 1999, the extent was quite broad. The pattern of spread in the Smith River drainage started slowly in the first three years, then accelerated. It appeared to be still spreading in $1999^{6}$.

In the Williams Creek watershed, in Oregon, a high rate of spread was recorded over three years. Of the 55 sites tested, 28 percent were infested in 1998, 33 percent in 1999, and 40 percent in $2000^{7}$.

Table 4.2-Port-Orford-cedar plant communities at risk (more than 10 percent infested by P. lateralis) in California (Jimerson et al. 1999)

Plant Association

Percent of Area

Infested

Tanoak-Port-Orford-cedar-Coast Redwood/Evergreen Huckleberry

$54 \%$

Tanoak-Port-Orford-cedar-California Bay/Evergreen Huckleberry

$27 \%$

Tanoak-Port-Orford-cedar-White Alder -Riparian

$22 \%$

Tanoak-Port-Orford-cedar/Evergreen Huckleberry-Western Azalea

$17 \%$

Port-Orford-cedar-Western White Pine / Labrador Tea/California Pitcher Plant

$15 \%$

Port-Orford-cedar-Western White Pine / Western Azalea-Dwarf Tanbark-Labrador Tea

$12 \%$

Port-Orford-cedar/Salal

$11 \%$

\footnotetext{
${ }^{6}$ Rose, Donald L. 1999. Personal communication. Former Port-Orford-cedar Program Manager, USDA Forest Service, Siskiyou National Forest, Grants Pass, OR. Currently environmental coordinator, Bonneville Power Administration, 905 NE $11{ }^{\text {th }}$ Avenue, Portland, OR 97232.

${ }^{7}$ Betlejewski, Frank. 2001. Personal communication. Port-Orford-cedar Program Manager, USDA Forest Service, Southwest Oregon Forest Insect and Disease Service Center, 2606 Old Stage Road, Central Point, OR 97502.
} 


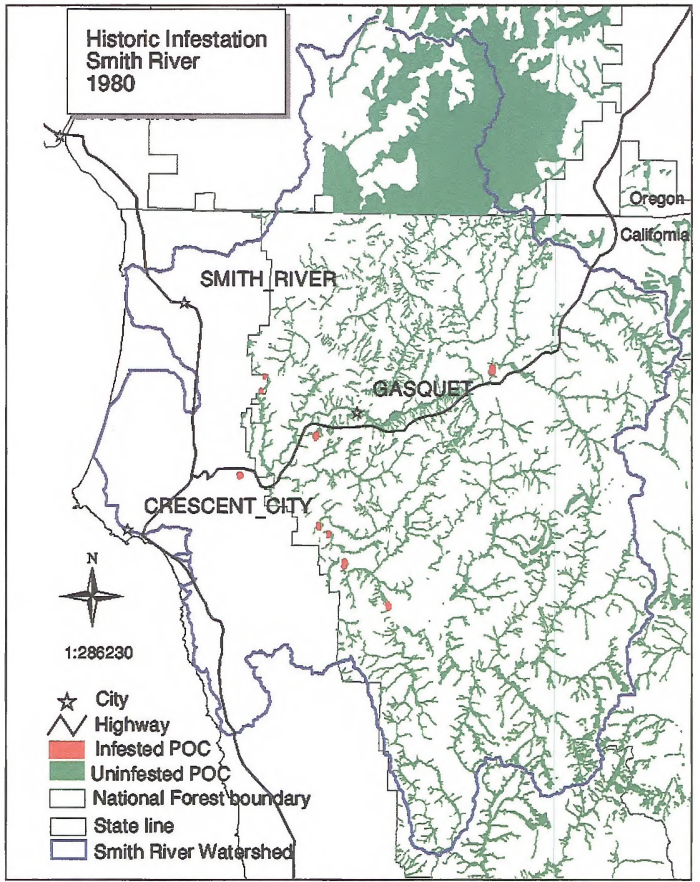

Figure 4.3-Phytophthora lateralis infestation, Smith River 1980 


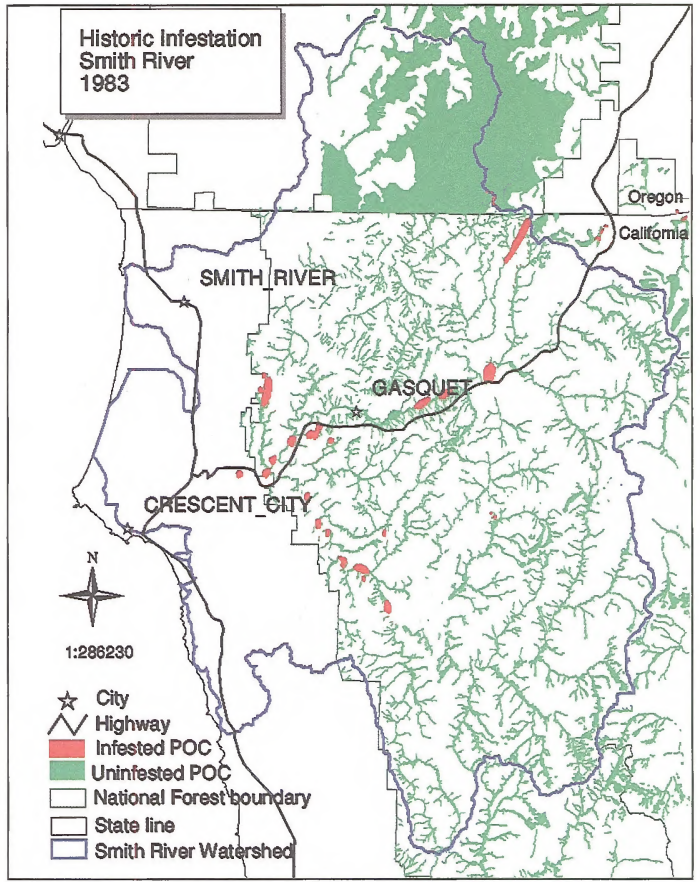

Figure 4.4-Phytophthora lateralis infestation, Smith River 1983 


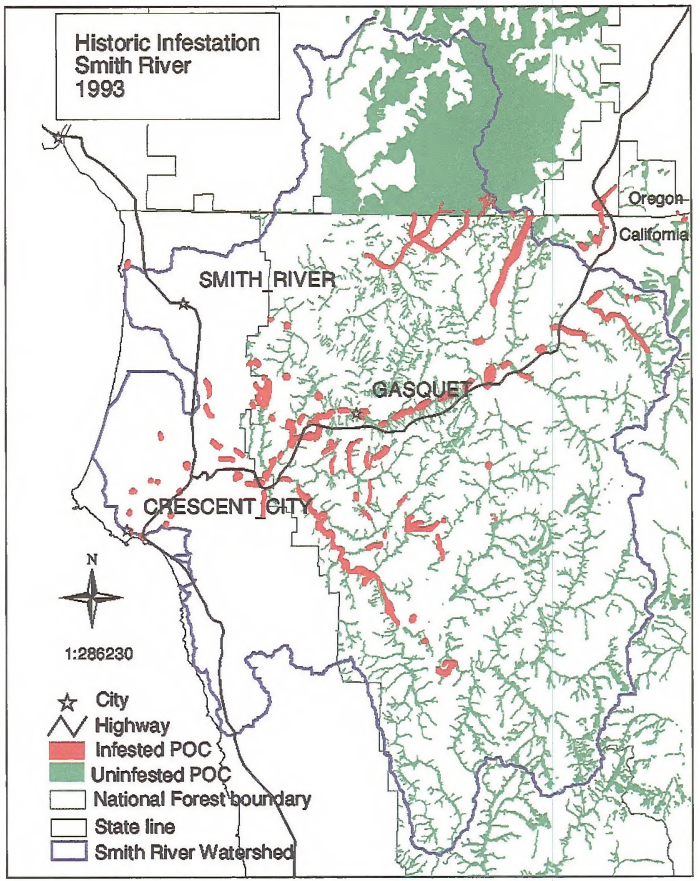

Figure 4.5-Phytophthora lateralis infestation, Smith River 1993 


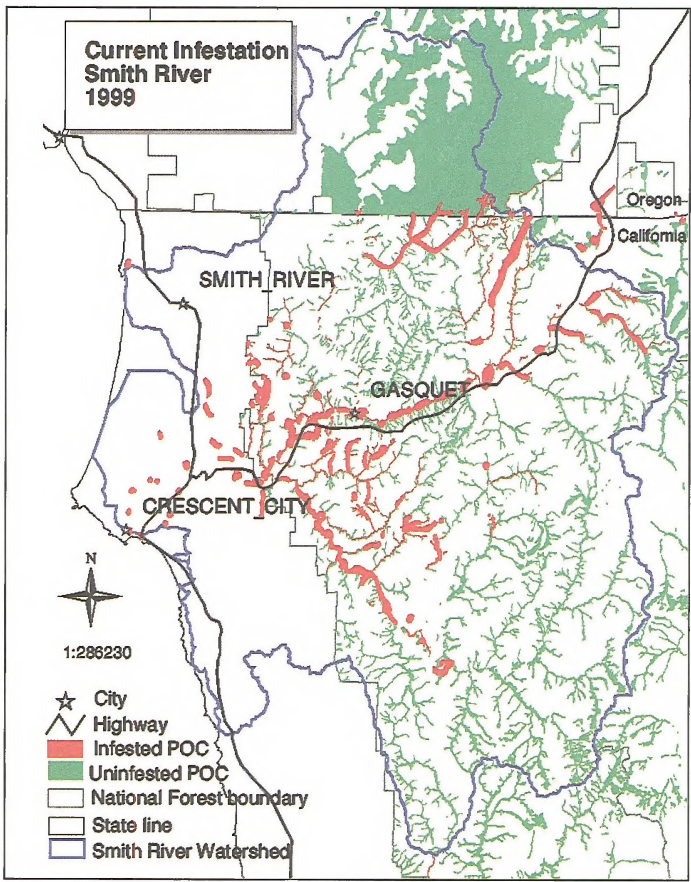

Figure 4.6-Phytophthora lateralis infestation, Smith River 1999 


\section{Status of Infestation Relative to Roads}

In California, most of the infested areas are in the northern part of the Six Rivers National Forest (fig. 4.7). Most of the infestations are in roaded areas. A few infestations are in areas that are roadless or behind barriers. The disjunct populations of Port-Orford-cedar on the Shasta-Trinity National Forest are unprotected, yet uninfested. Some nearby private lands along the Sacramento River are infested.

On the Siskiyou National Forest, most of the infested area is roaded (fig. 4.8). Only a small amount of infestation is present in areas greater than 500 feet from a road or behind a barrier.

On a smaller landscape scale, the Elk Creek watershed map shows the infestations clearly associated with roaded areas and rivers or streams (fig. 4.9).

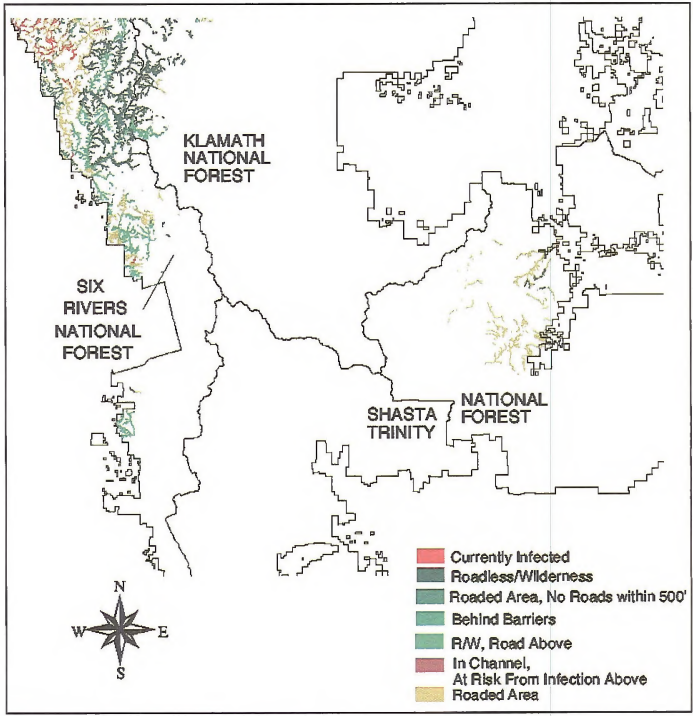

Figure 4.7-Condition of Port-Orford-cedar in National Forests in California relative to factors that influence disease spread, 2001 


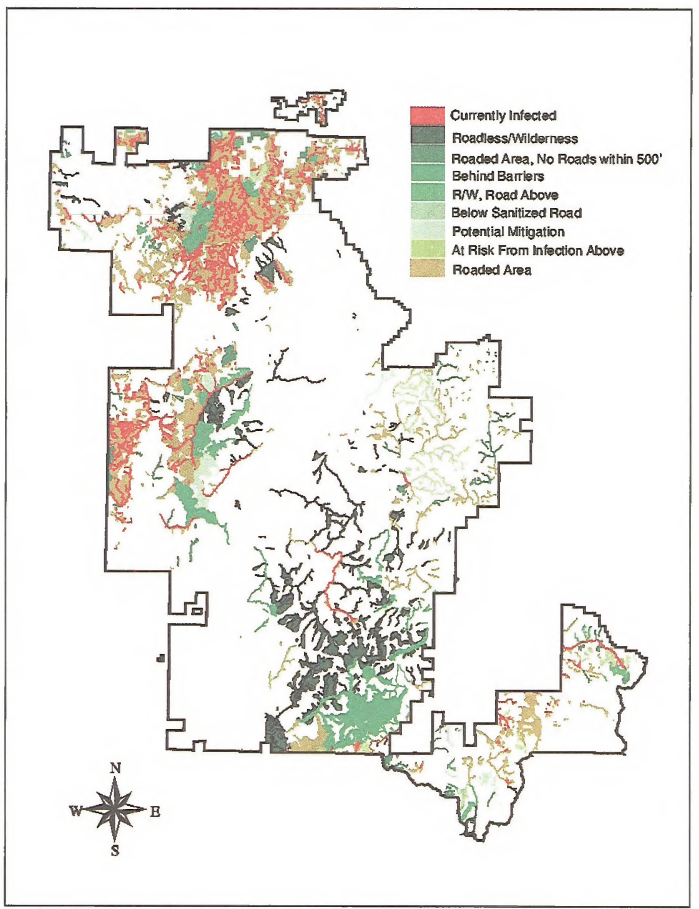

Figure 4.8-Condition of Port-Orford-cedar in the Siskiyou National Forest relative to factors that influence disease spread, 2001 


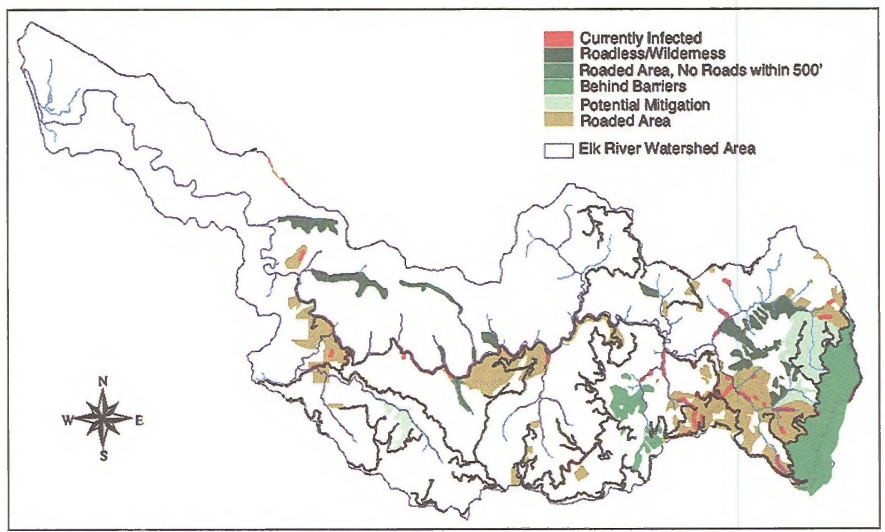

Figure 4.9-Condition of Port-Orford-cedar in the Elk River Watershed, Siskiyou National Forest, relative to factors that influence disease spread, 2001

\section{Landscape Level Impacts of Port-Orford- Cedar Root Disease}

Results of several surveys demonstrate the kinds of impacts that $P$. lateralis can have across a landscape:

\section{Coquille River Falls Research National Area}

Data from three inventory surveys done in 1958, 1986, and 1999 in the Research Natural Area (RNA), with the goal of documenting the long-term effects of more than 45 years of chronic infestation, suggest that the overall amount of infestation has remained more or less constant since 1958 (Goheen et al. 1986b, Hansen 2000). Many Port-Orford-cedar have survived in the RNA, though nearly all close to streams or other wet areas are dead. In general, live Port-Orford-cedar is either upslope from water or in the headwaters above the road locations.

\section{Powers Roads}

Surveys conducted along road sections that were infested since at least 1958 on the Powers Ranger District, Siskiyou National Forest, and in adjacent areas demonstrated that substantial numbers of Port-Orford-cedar survived even though inoculum levels in certain places along the roads obviously remained high. Disease-caused mortality continued to occur, and there was progressive disease spread downslope (Goheen et al. 1986a, Hansen 1993). 


\section{Smith River Watershed}

P. lateralis spread within a watershed is shown in the historical mapping of the Smith River drainage in California. The first occurrence of the pathogen in the Smith River drainage is thought to have been in the early 1960s. These first observed disease centers were small and confined to the lower Smith River in and around Crescent City ${ }^{8}$. A map with periodic updates of pathogen spread was maintained beginning in 1980 . New mortality of Port-Orford-cedar was mapped in 1983, 1984, 1986, 1987, 1989, and 1998. These infested areas were hand drawn on District maps and are rough estimates of sizes and locations of the infestations. The maps provide a dramatic example of how rapidly the pathogen can spread within and between drainages (figs. 4.3 through 4.6). The pathogen spread from nine small confined areas in 1980 to more than 16 percent of the watershed 20 years later. Pathogen spread appears greater in the mid- to late 1980s. The rapid spread may have resulted from a rise in inoculum, causing a classic epidemic curve, or an increase in the intensity of mapping efforts during this time. The latter culminated in the mapping of all stands with at least 10 percent crown cover of PortOrford-cedar in 1998. The mapping in 1980 through 1989 delineated the occurrence of dead Port-Orford-cedar and included areas with widely scattered or clumpy distribution. In 1998, there was a total of 3,174 acres that had some level of disease-caused mortality within the Smith River drainage.

\section{Literature Cited}

Goheen, E.M.; Cobb, D.F.; Forry, K. 1986a. Roadside surveys for Port-Orford-cedar root disease on the Powers Ranger District, Siskiyou National Forest. Portland, OR: U.S. Department of Agriculture, Forest Service, Pacific Northwest Region. Administrative report. 19 p. On file with: Southwest Oregon Insect and Disease Service Center, J. Herbert Stone Nursery, 2606, Old Stage Road, Central Point, OR 97502.

Goheen, E.M.; Cobb, D.F.; Forry, K. 1986b. Survey of the Coquille River Falls Research Natural Area. Portland, OR: U.S. Department of Agriculture, Forest Service, Pacific Northwest Region. Administrative report. 10p. On file with: Southwest Oregon Forest Insect and Disease Service Center, J. Herbert Stone Nursery, 2606, Old Stage Road, Central Point, OR 97502.

Hansen, E.M. 1993. Roadside surveys for Port-Orford-cedar root disease on the Powers Ranger District, Siskiyou National Forest. Corvallis, OR: Oregon State University. Unpublished report. 17p. On file with: Southwest Oregon Forest Insect and Disease Service Center, J. Herbert Stone Nursery, 2606, Old Stage Road, Central Point, OR 97502.

Hansen, E.M. 2000. Demographics of Port-Orford-cedar on sites infested with P. lateralis for many years. Corvallis, OR: Oregon State University. Unpublished report. 5 p. On file with: Southwest Oregon Forest Insect and Disease Service Center, J. Herbert Stone Nursery, 2606, Old Stage Road, Central Point, OR

Jimerson, T.M.; McGee, E.A.; Jones, J.K. 1999. Port-Orford-cedar plant association mapping in California. Eureka, CA: U.S. Department of Agriculture, Forest Service, Six Rivers National Forest. 37 p.

\footnotetext{
${ }^{8}$ Wells, Ken. 1996. Personal communication. Retired. Timber Management Assistant, U.S. Department of Agriculture, Forest Service, Region 5.
} 


\section{Chapter 5 \\ Genetics of Port- Orford-Cedar}

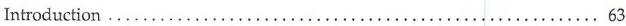

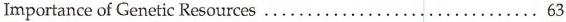

Genetic Structure of a Species . . . . . . . . . . . . . . . . . . 63

Measurement of Genetic Structure: genetic tests .............. 64

Genetic Variability . . . . . . . . . . . . . . . . . . . . . . . . . . . 65

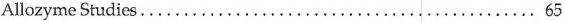

Common Garden Studies . . . . . . . . . . . . . . . . . . . . . . 66

Seed Zones and Breeding Zones $\ldots \ldots \ldots \ldots \ldots \ldots \ldots \ldots \ldots \ldots \ldots \ldots \ldots \ldots \ldots \ldots \ldots$

Port-Orford-Cedar Breeding Block Designations ................. 71

Implications for Genetic Conservation . . . . . . . . . . . . . . . . . . 73

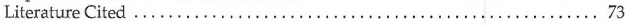

Authors: Jay Kitzmiller, Richard A. Sniezko, James E. Hamlin, Roderick D. Stevens, and Kirk C. Casavan

June 2001 
A Range-Wide Assessment of Port-Orford-Cedar on Federal Lands 


\section{Introduction}

\section{Importance of Genetic Resources}

In order to promote and sustain health, biodiversity, and productivity of public forest resources, it is necessary to conserve the basic natural resources (water, soil, air, elements, and biota) and their functional processes. The genetic materials of the biota are fundamentally important natural resources, because genetic diversity among and within species is the basis for all biological diversity. Genetic diversity is essential for the survival and adaptation of species to new, changing environments. In addition, genes program the structure, function, and response of individual organisms to their environment. Together with other factors they determine the health and vigor of forest stands.

Genetic materials are subjected to natural processes that need to be understood and managed. The hereditary process, involving DNA self-replication and transmission of exactly one-half of the genes from each parent to their offspring, provides continuity and preservation of genetic material across generations and from cell to cell within the same individual. Because of heredity, offspring tend to resemble their parents. Therefore, by controlling the seed parents, managers can influence traits of the seedlot. In addition to this stable hereditary process, there is an evolutionary process involving selection, gene flow, mutation, and drift that cause changes in gene frequencies of populations. Management activities may simulate evolutionary forces, e.g. transplanting is a gene flow activity and selection of seed parents is a selection activity.

\section{Genetic Structure of a Species}

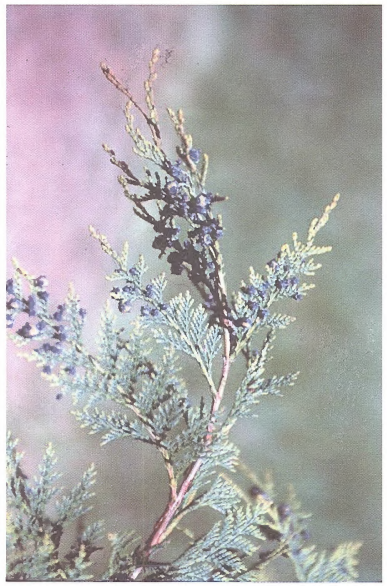

These evolutionary forces, plus the mating pattern of the species, results in a unique pattern of genetic variation for each species. Knowledge of the diversity and distribution of genes among and within populations of a species is crucial to genetic management, whether the purpose is to develop strategies to conserve natural populations or to improve breeding populations. A genetic inventory that describes the extent and pattern of genetic variation across the range of a species is one prerequisite to protecting the adaptive structure of a species and to monitoring genetic changes due to pests, climate extremes, and management practices.

Figure 5.1-Port-Orford-cedar branch bearing cones 
In the major conifers, the genetic composition of natural populations usually changes along environmental gradients (clinal variation pattern). Typically, forest trees adapt to temperature and moisture gradients which, in turn, are often associated with geographic variables such as elevation, latitude, or distance from the ocean. Trees may evolve adaptations to rather abrupt and major changes in soil parent material over short distances (edaphic ecotypic variation pattern). As a rule, trees become generally, but not perfectly, adapted to local environments. This is because trees often require decades to reproduce, the environment is constantly changing, and other forces (e.g. gene flow, recombination, and genetic drift) may counteract the effects of selection. The genetic gradients commonly follow paths from milder and more productive sites to harsher and less productive environments. Parent trees from the mild, productive sites usually produce offspring that are faster growing, grow for a longer period of time during the year, and in some situations may be less resistant to drought and cold stress than those from harsher environments.

\section{Measurement of Genetic Structure: genetic tests}

Genetic differentiation patterns in adaptive traits along geographic, elevational, and edaphic gradients must be known before seed can be successfully transferred during reforestation. The genetic architecture of commercial conifers in California and Oregon has been well-studied using provenance field trials (common garden studies) and electrophoretic analysis of certain enzymes (allozyme studies), the key tools for measuring and understanding natural genetic variation patterns. DNA technologies are now used to complement these two common methods.

Allozyme studies produce relatively quick and inexpensive results. Allozyme techniques provide useful quantitative measures of genetic structure (pattern of variation among and within populations), genetic diversity (heterozygosity), and mating system (outcross percent) for certain enzymes. These enzymes are common to a wide variety of species, and since they exhibit Mendelian genetics, they are called allozymes. The allozyme parameters allow standards for comparisons across species and can provide quantitative information about genetic systems that characterize different species. Some practical limitations in allozyme studies are the small portion of the genome expressed, the gene level of measurement, the neutrality of many allozyme genes, and the general absence of measurement of adaptive traits. Allozyme studies are not a replacement for common garden trials, because allozymes can not show adaptive responses of trees to field environments and allozymes tend to underestimate variation among populations, especially in conifers. However, multi-locus allozyme variation may indicate underlying adaptive variation and therefore may be useful for delineating tentative breeding zones when the multi-locus pattern is closely correlated to geographic or environmental variables (Westfall and Conkle 1992).

Seed zoning must be primarily based on common garden field studies where whole plant response can be evaluated. Common garden studies with multiple and contrasting test environments provide direct comparisons of genetic materials for many adaptive traits tested under field conditions. With seed sources tested over multiple sites, the pattern of adaptive response can be determined for each seed source and then related to presumed natural selective factors at point of origin. For example, if natural selection were a primary force, the pattern of differences among populations for adaptive traits should correspond with a pattern of environmental differences where populations originated. Allozyme and common garden studies conducted together complement one another, providing both basic genetic parameters and practical field expression of adaptive traits. 


\section{Genetic Variability}

During the previous two decades, several genecological studies have been conducted on Port-Orford-cedar. Allozyme studies and common garden studies are two key tools used for measuring and understanding natural genetic variation patterns.

\section{Allozyme Studies}

In 1991, investigators examined the allozyme variation of nine Port-Orford-cedar stands in California that represented the extremes in elevation, latitude, and longitude of the species range in that state (Millar and Marshall 1991). Seven of the stands were located in the coastal range, while two came from interior, disjunct populations. Port-Orfordcedar was found to be moderately variable in allozymes (less than widespread, dominant species such as Douglas-fir). The inland populations differed in allele frequencies from coastal populations, being more monomorphic, had higher frequency of common alleles, and had a lower percent of polymorphic loci. In addition, the inland populations were, on the average, only one-half as variable as the most variable coastal population. Not only was there a clear separation between coastal and inland groups, but also the two inland populations were distinct from each other. On the average, for all stands studied, 5 percent of the total allozyme variation was attributed to differences among stands and 95 percent to differences within stands. Much greater differences occurred among stands in the inland than in the coastal group, suggesting that inland populations may have been isolated from each other long enough for genetic drift or selection effects to cause differentiation. As a group, the inland populations within the Sacramento and Trinity River drainages (Trinity and Scott Mountains) had greater genetic diversity among stands and less within stands. Within the coastal group, the Horse Mountain population had enough unique alleles and divergent frequencies to be relatively distinct from other coastal populations. The Shelly Creek population displayed high genetic diversity within its stands.

Millar et al. (1991) examined the relationship between allozyme diversity and ecological diversity (soil and elevation). To determine if there was a correlation within a local area, foliage was sampled from trees along the Middle Fork and South Fork of the Smith River, at low and high elevations, and on fertile and ultramafic soils. These contrasts have been found by ecologists to significantly discriminate between Port-Orford-cedar plant associations in northwestern California. Ecological data for stands between plant associations were strongly differentiated by elevation and soil fertility, and Millar et al's (1991) results showed strong correlations of allozyme diversity with ecological habitat over short distances.

Elevation was a stronger factor than soil type in determining genetic differentiation (48 percent of the genotypes were different between elevations). The effect of soil type varied depending on elevation. At low elevations, differences between soil types were nearly as great as the overall elevation effect, but at high elevation the soil effect was relatively low. At low elevations, the mismatch of genotypes between soil types was 49 percent, while at high elevation the mismatch was only 14 percent. Thus, habitat conditions at high elevations were apparently severe enough for selection to mask or override the effect of soil type. Soil fertility more strongly separated plant associations than genetic data.

There was a trend in both plant associations and genetic data (weaker in genetic data) for higher diversity at low elevations. This study suggested that seed collected from coastal California should be identified by elevational zones and, at the low elevations, by ultramafic and non-ultramafic soils. 
In 1992, investigators once again examined allozyme variation of Port-Orford-cedar stands, but on a much wider scale (Millar, et al. 1992). The sources came from 46 stands in California and 36 stands in Oregon. Additional single-tree collections were made to fill gaps between stands and to sample unusual sites. The mean allozyme diversity was slightly higher for Oregon than for California stands, but with the range of diversity among stands in California being greater. Low within-stand diversity was found scattered across the range in Oregon, but only occurred within the California groups of stands in the Sacramento and Trinity drainages. In each state, the pattern of allozyme variation among populations was strongly linked with latitude, longitude, and elevation. In Oregon, the cline was strongest along north-south (latitude), weaker along eastwest (longitude), and weakest along elevational gradients. In California, the cline was strongest along east-west (longitude) with elevation being a relatively strong determinant of allozyme diversity.

\section{Common Garden Studies}

Despite their considerable utility, allozyme studies cannot show adaptive responses of trees to field environments. Thus, in 1995, a major effort began to establish range-wide common garden tests to further evaluate the genetic variability within Port-Orford-cedar.

Seed was collected from 344 healthy parent trees on federal land from 1991 through 1994 by the Forest Service and Bureau of Land Management (BLM). Stands were sampled throughout much of the species' range from the extreme northwestern portion (Oregon Dunes) to the extreme southeastern stands (Pond Lily Creek, Upper Trinity River). Sample trees were grouped into 10 regional watersheds, six in Oregon and four in California, and into 52 stands, 36 in Oregon and 16 in California. However, the distribution of watersheds, stands within watersheds, and trees within stands, was not even. Two different hierarchical models were employed to partition the genetic effects: 1) ecological or watershed model with watersheds, stands, and families, and 2) a breeding model with breeding zones, seed zones, and families (tables 5.1 and 5.2). The grouping of trees into four tentative breeding zones was based on combinations of similar seed zones with boundaries as currently drawn (USDA 1969 and 1973). These tentative breeding zones were compared to the ecological (watershed) model. In 1996, a short-term and a long-term common garden study were established. The short-term study was planted in raised beds at two nurseries using 298 of the families. Four sites in 1996 and one site in 1998 were out-planted for the long-term study using 266 of the families. In addition, the 344 families were tested for disease resistance (refer to Chapter 6).

Short-term raised bed study design-In spring 1996, 1-0 seedlings grown in Korbel, California, were transplanted to two locations, Dorena Tree Improvement Center, Cottage Grove, Oregon, and Humboldt Nursery, McKinleyville, California (figs. 5.2 and 5.3). The Humboldt site is 1.9 miles from the ocean at 249 feet elevation.

The experimental design was a randomized, complete block with six blocks and 298 families. At Dorena, all blocks were located in raised beds with organic rooting medium, but three blocks were shaded with 47 percent shade-cloth during the growing season (fig. 5.3). At Humboldt, three blocks were in conventional nursery beds with mineral soil, while three blocks were in raised beds with organic rooting medium and partially shaded by adjacent trees. The spacing of seedlings was slightly greater at Dorena's raised beds compared to Humboldt's conventional beds and raised beds.

\footnotetext{
${ }^{9}$ Through international cooperation in genetic conservation of forest trees, these seed sources and the study design were also replicated in several out-plantings in Spain.
} 
Table 5.1-Port-Orford-cedar population samples by watershed for the common garden study (ecological model)

\begin{tabular}{lrrrll}
\hline $\begin{array}{l}\text { Regional } \\
\text { Watershed }\end{array}$ & No. Stands & No. Trees & Elevation Range & $\begin{array}{l}\text { Latitude Range } \\
(\mathrm{deg})\end{array}$ & $\begin{array}{l}\text { Longitude Range } \\
(\mathrm{deg})\end{array}$ \\
\hline Trinity & 2 & 9 & $5200-5299$ feet & $41.0885-0.1255$ & $122.4720-0.5301$ \\
Sacramento & 3 & 30 & $3750-5200$ feet & $41.2200-0.2500$ & $122.3959-0.4600$ \\
Klamath & 3 & 24 & $2999-4501$ feet & $41.0000-0.8234$ & $123.4651-0.9000$ \\
Smith & 8 & 40 & $1319-5200$ feet & $41.7237-0.9657$ & $123.6493-124.0690$ \\
Illinois & 2 & 13 & $3360-3501$ feet & $42.0332-0.1250$ & $123.3553-0.5535$ \\
Applegate & 4 & 29 & $2300-4501$ feet & $42.1188-0.2073$ & $123.2789-0.4057$ \\
Rogue & 6 & 28 & $2178-3599$ feet & $42.4277-0.6917$ & $123.7248-124.2843$ \\
Coquille & 18 & 82 & $400-2749$ feet & $42.7083-43.2600$ & $123.7800-124.1333$ \\
Dunes & 4 & 26 & $49-194$ feet & $43.3400-0.4500$ & $124.2500-0.3400$ \\
& & & & &
\end{tabular}

Table 5.2-Port-Orford-cedar population samples by tentative breeding zones for the common garden study (breeding model)

\begin{tabular}{lllc}
\hline Breeding Zones & Seed Zones & Watersheds & $\begin{array}{l}\text { Families } \\
\text { (no.) }\end{array}$ \\
\hline North Coast & $071,072,081$ & Dunes, Coquille, Sixes, Rogue & 155 \\
North Interior & 511,512 & Applegate, Illinois, Smith & 57 \\
South Coast & $091,301,302$ & Smith, Klamath & 47 \\
South Interior & 331,521 & Trinity, Sacramento & 39 \\
\hline
\end{tabular}

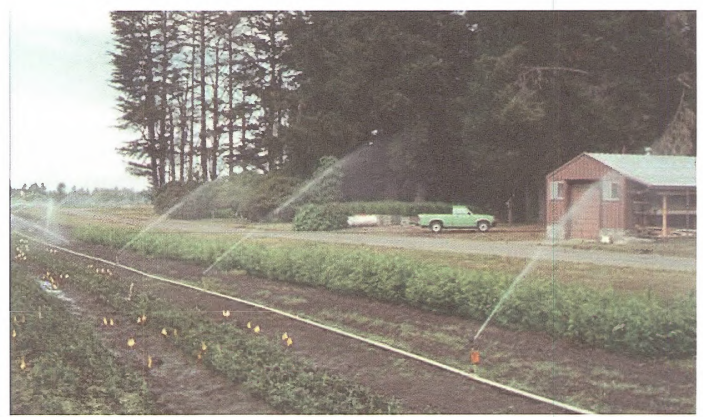

Figure 5.2-Raised bed, short-term common garden study at the Humboldt Nursery site, McKinleyville, California 


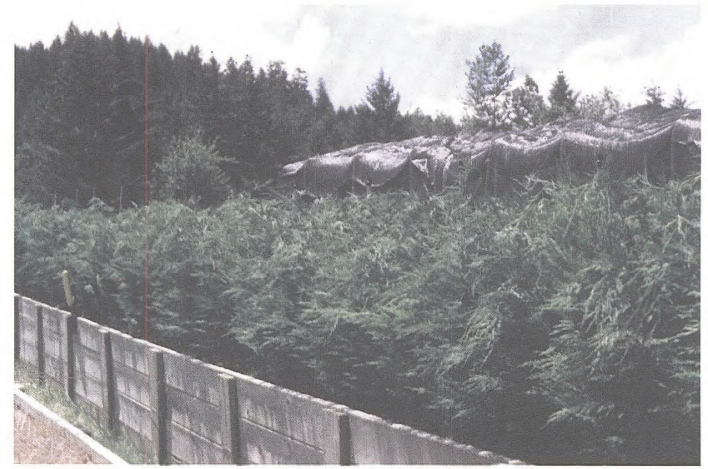

Figure 5.3-Raised bed, short-term common garden at the Dorena Tree Improvement Center, Cottage Grove, Oregon

Short-term raised bed study: Height growth results (Kitzmiller and Sniezko 2000)— The environmental components, transplanting location and "shade" treatments, had significant effects on 2-year height growth (Appendix D presents the analysis of variance [ANOVA] tables and means). Surprisingly, the inland location had superior height compared to the coastal location both years, and "shading" was inferior to open sun the second year. The height growth response of Port-Orford-cedar families from different geographic regions and stands revealed a strong genetic structure with a welldefined geographic pattern. Height potential was highly related to genetic source at the watershed, stand, and family levels. The genetic structure for early height is described in the proportion of total variance residing at various source levels. Genetic main effects were strong and accounted for 47.5 percent (watershed $=37.4$ percent, stands within watershed $=3.4$ percent, families within stands $=6.7$ percent ) of the total variability. Strong clinal patterns were found for height potential with source elevation, latitude, and longitude. Genetic by environment $(\mathrm{G}-\mathrm{x}-\mathrm{E})$ is a parameter used to assess changes in the performance of genotypes when grown under different environments. G-x-E interaction accounted for 6.1 percent of the variability and blocks accounted for only 9.9 percent. $\mathrm{G}-\mathrm{x}-\mathrm{E}$ interactions, though statistically significant at watershed and family levels, were minor sources of variability in height, and were due to scale effects rather than rank changes. Southern and high elevation inland sources had low growth potential at both locations, while northern and low elevation coastal sources had high growth potential. Second year total height decreased 11.1 inches (28.2 centimeters) per 3281 feet (1000 meters) increase in source elevation. Trees from the low elevation Sixes/Elk watershed averaged 60 percent taller than those from the high elevation Trinity watershed. Trees from low elevation, northern, and coastal sites had less mortality, higher seed weight and higher filled seed percent. 
These tentative results show population structure and geographic patterns similar to, though much stronger than, the allozyme studies previously mentioned. Current results suggest that gene conservation practices should encompass, 1) seed zoning by watershed, subdivided by elevation bands, and 2) protecting the broad gene base for growth, including the adaptive extremes near the northern and southern limits.

Short-term raised bed study: Variation in height growth phenology (Zobel et al., in press)-Timing of height growth was determined for 54 of the families in the short-term raised bed study. Measurements were made during the second year of growth. The proportion of early-season growth declined and the proportion of late-season growth increased with changes in seed source location from high to low elevations, from south to north, and from east to west. This pattern was parallel to that of seedling height and of actual elongation in each of three periods during the growing season. The tallest trees (from the Oregon coast near the species' northern range limit) grew more in each period, but had the greatest proportion of late-season height growth. Planting such genotypes where late summer drought or early frost is common may threaten their survival. Use of breeding zones that limit genotype transfer distance may avoid such damage. Seedlings grown at the coastal nursery had a lower proportion of early-season growth and more in late-season than seedlings grown inland.

Short-term raised bed study: Variation in water relations characteristics of leaders (Zobel et al. 2001) —Water relations attributes of immature tissues of the terminal leader and its branches were measured on a subset of the short-term raised bed study families. Leader tissue provided consistent data and allowed interpretations directly useful for assessing effects on height growth. Osmotic potentials were higher than reported for most conifers. Osmotic potentials declined at both nurseries as the season progressed. The osmotic amplitude (osmotic potential at full turgor - osmotic potential at zero turgor) also increased during the season. Osmotic potential at full turgor was more negative and osmotic amplitude greater at the inland nursery than at the coastal nursery. Correlations with geographic location of the seed sources were weak. The small size of significant differences among families, nurseries, and sampling periods, and some inconsistencies among attributes measured, suggest that many of the differences may be of marginal physiological significance. However, correlations with plant size and timing of height growth suggest that, as one progresses from high elevation, southeastern locations toward the northwestern coast, where seedlings become larger and grow more late into the season, the relative water content at zero turgor increases, osmotic potential at zero turgor declines, and the tissue elasticity index rises. Larger genotypes thus appear to be less desiccation tolerant. When selecting genotypes for planting outside their native habitat, decisions based on the clear geographic patterns in tree size and timing of growth, reported elsewhere, should effectively account for the differences in water relations that appeared in this study.

Long-term common garden out-planting study - Short duration tests in low-stress nursery environments are not well suited for the expression of cumulative response to environmental stresses. Long-term field common garden studies are designed to reveal adaptive-based G-x-E interactions for guiding seed zoning and transfer (figs. 5.4 and 5.5). Four common garden sites were planted in 1996: Humboldt Nursery in McKinleyville, California, Trinity Lake on the Shasta-Trinity National Forest, and Althouse and Chetco on the Siskiyou National Forest. In 1998, an additional site, Battle Axe, was established on the BLM Roseburg District, which expanded the original 266 families to include samples from the northeast part of the range of Port-Orford-cedar. Height measurements have been taken on the Humboldt and Trinity Lake sites. Results show that watershed mean three-year height was inversely related to survival at the inland Trinity Lake site. North coastal watersheds, although much taller, had 60 to 70 percent survival, while extreme southeastern interior lots had 90 percent survival. Overall plantation growth and survival were better at the coastal Humboldt Nursery field site. A geographic cline in height growth was associated with latitude, longitude, and elevation of seed origin. 
Northern, low elevation, coastal seed sources grew taller than southern, high elevation, interior sources at both plantation sites. However, these faster growing sources also showed the greatest relative reduction in growth and survival when planted at the inland Trinity Lake site.

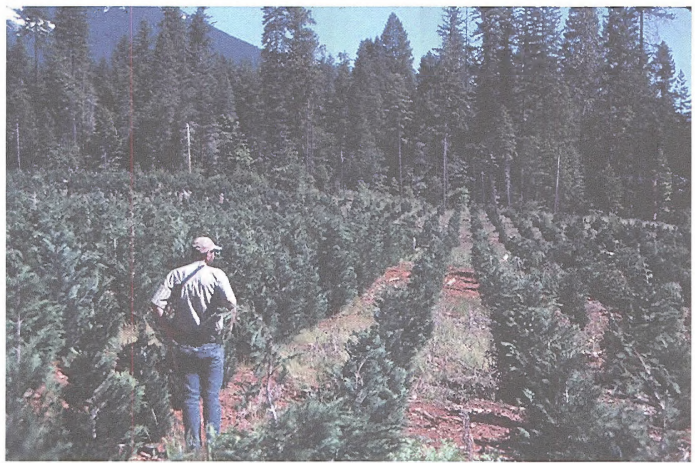

Figure 5.4-Long-term out-planting site at Weaverville-Trinity Lake, California

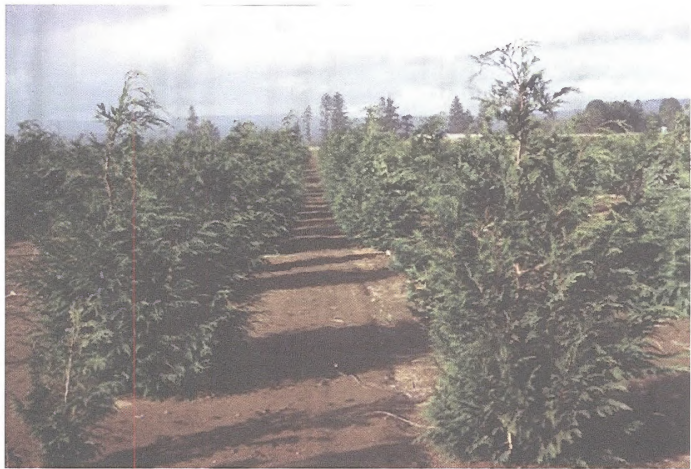

Figure 5.5-Long-term out-planting site at Humboldt Nursery, McKinleyville, California 


\section{Seed Zones and Breeding Zones}

General adaptation of trees along major geographic gradients is the basis for seed zoning. Seed zoning is a management tool that is used to protect the natural genetic structure of adaptive traits in forest tree species against undesirable gene transfer from their natural origin to planting sites. California and Oregon conifers have adapted through natural selection to temperature and moisture gradients and to different soil parent materials. These gradients are often associated with elevation, latitude, and distance to the ocean. Seed zones based on these geographic variables afford protection against dysgenic seed transfers. The purpose of seed zones is to partition the region into adaptively-similar zones within which wild seed collections of native trees can be freely moved without problems of maladaptation.

Geographic seed zones may require further subdivision of seedlots based on adaptation to extreme soils types. Genetic diversity in a natural forest within a relatively small geographic area presents a challenge. Are these differences adaptive in nature or are they simply vital components of a diverse natural breeding population? Managers must decide what seed trees to select and whether to keep seed separate or mix seeds from mild and harsh sites together, and if so, in what proportions. Strategies may favor either mixing seed parents within zones or keeping seed separate by local site. For species such as Port-Orford-cedar that occur on both ultramafic and granitic soils, there may be sufficient adaptive genetic differentiation to warrant separate seed lots for these extreme soil types within a geographic seed zone. Because seed zones are a practical tool, they must be large enough to be economical and easy for people to use, yet small enough to protect natural patterns of adaptation for the species.

Breeding zones have a similar purpose as seed zones except that seeds from selective breeding orchards are deployed instead of wild seeds. Breeding zones may be broader than seed zones provided that selected genetic stock has been proven through fieldtesting to be broadly adapted.

The genetic variability studies completed so far for Port-Orford-cedar indicate geographic zoning based on major watersheds or seed zones in combination with elevation bands. Preliminary breeding zones have been delineated, and will be used to guide seed transfer and selective breeding activities. Elevational bands should be no greater than 1,640 foot ( 500 meter) intervals up to 3,281 feet (1000 meter) elevation, and then becoming 820 foot ( 250 meter) intervals between 3,281 and 6,562 feet (1,000 and 2,000 meter) elevation. In this breeding zone designation, seed zones and/or portions of watersheds adjacent to one another within the coast or interior have been combined within these elevational bands. Geographic seed zones or breeding zones may require further subdivision of seedlots based on adaptation to extreme soil types. Species, such as Port-Orford-cedar, that occur on both ultramafic and granitic soils, may have sufficient adaptive genetic differentiation to warrant separate seed lots for these extreme soil types within a geographic seed zone.

\section{Port-Orford-Cedar Breeding Block Designations}

A breeding block designates the geographic area that envelopes a number of breeding zones. Breeding blocks have been delineated on the basis of a genetic common-garden study (Kitzmiller and Sniezko 2000) and general knowledge of southwestern Oregon and northern California species genecology (fig. 5.6). The common-garden study noted genetic variation associated with latitude, longitude, and elevation of the seed sources. Additional studies (Millar et al, 1991; Zobel et al, in press) have also noted differences 
between the coastal and inland sources of Port-Orford-cedar. These breeding blocks have been delineated on the basis of this perceived genetic structure. Breeding zones are represented by elevation bands within the respective breeding blocks, and designate units of land in which improved populations (via genetic testing and breeding activities) are being developed. The elevation bands are: 1) less than 1,500 feet, 2) 1,501 to 3,000 feet, 3) 3,001 to 4,000 feet, 4) 4,001 to 5,000 feet, 5) 5,001 to 5,500 feet, 6) 5,501 to 6,000 feet, and 7) 6,001 to 6,500 feet. An elevation band within a breeding block constitutes a single breeding zone. Table 5.3 summarizes the six blocks depicted on the map.

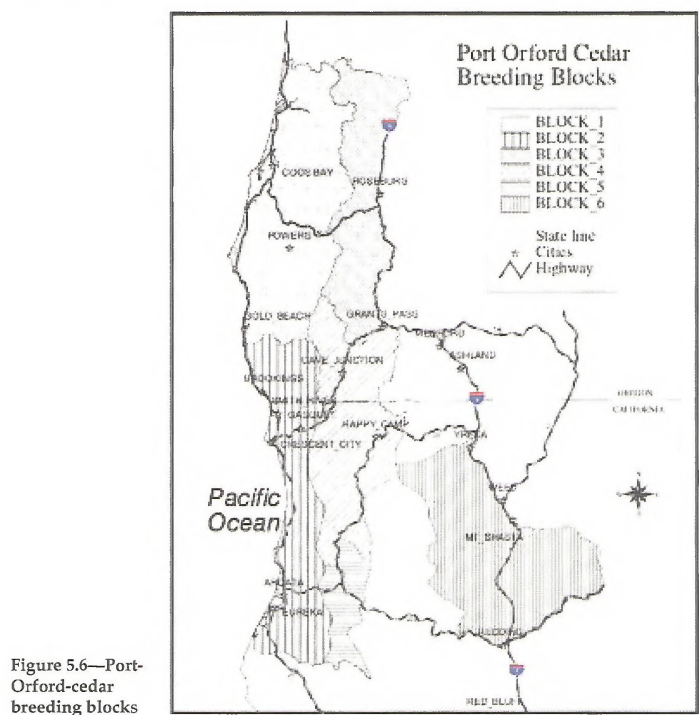

Table 5.3-Description of location and seed zones for Port-Orford-cedar breeding blocks

\begin{tabular}{|c|c|c|}
\hline $\begin{array}{c}\text { Breeding } \\
\text { Block }\end{array}$ & General Geographic Area & $\begin{array}{l}\text { Reference to State Tree Zones } \\
\text { (USDA } 1969 \text { and 1973) }\end{array}$ \\
\hline BB1 & North coast range of Port-Orford-cedar from Oregon Dunes to Gold Beach, Oregon & OR zones 071,072 , and portion of 081 \\
\hline BB2 & South coast range of Port-Orford-cedar from Gold Beach, Oregon to Eureka, California & Portions of 082 and $090(\mathrm{OR})$ and 091 and 092 (CA) \\
\hline BB3 & North inland range of Port-Orford-cedar from near Umpqua to near Provolt, Oregon & Portions of OR zones $270,081,511$, and 512 \\
\hline BB4 & South inland range of Port-Orford-cedar from Provolt, Oregon to near Orleans, California & $\begin{array}{l}\text { Portions of } 081,082,090,511 \text { (OR), } 512 \text { (OR and } \\
\text { CA), and } 301,302 \text { (CA) }\end{array}$ \\
\hline BB5 & Isolated Humboldt population(s) near Willow Creek, California & Portion of 303 (CA) \\
\hline BB6 & Range of Port-Orford-cedar in upper Trinity and Sacramento Rivers in California & Portions of 331 and $521(\mathrm{CA})$ \\
\hline
\end{tabular}




\section{Implications for Genetic Conservation}

Management practices could be directed at protecting the range of genetic sources using both in situ and ex situ measures.

The adaptive genetic structure of Port-Orford-cedar is strongly differentiated at the regional watershed level and at the tree-to-tree level within a stand. A priority for conserving genetic populations could be to protect large stands in each major watershed. More stands could be sampled to represent low elevation, south coastal soil ecotypes and the interior higher elevation watersheds, where stands often are small and the range is fragmented. In small stands, favor those with 50 or more interbreeding trees.

Continued protection of Port-Orford-cedar in Research Natural Areas, Botanical Areas, and other existing forest reserves is warranted. New conservation units and conservation areas could be identified where current coverage has gaps. In California, there are apparent gaps in the northeastern and west-central portions of the coastal distributions and in the upper Trinity River drainage. In Oregon, large stands of Port-Orford-cedar in the Sixes and Elk River watersheds could be conserved for high growth potential, high root disease resistance, and high genetic diversity.

\section{Literature Cited}

Kitzmiller, J.H.; Sniezko, R.A. 2000. Range-wide genetic variation in Port-Orford-cedar (Chamaecyparis lawsoniana [A. Murr.] Parl.). I. Early height growth at coastal and inland nurseries. Frontiers of Forest Biology: Proceedings of the 1998 joint meeting of the North American Forest Biology Workshop and the Western Forest Genetics Association. Journal of Sustainable Forestry. 10:57-67.

Millar, C.I.; Delany, D.L.; Westfall, R.D. 1992. Genetic diversity in Port-Orford-cedar: range-wide allozyme study. Administrative report. 4 p. On file with: Southwest Oregon Forest Insect and Disease Service Center, J. Herbert Stone Nursery, 2606, Old Stage Road, Central Point, OR 97502.

Millar, C.I; Delany, D.L.; Westfall, R.D.; Atzet, T.; Jimerson, T.; Greenup, M. 1991. Ecological factors as indicators of genetic diversity in Port-Orford-cedar: applications to genetic conservation. Administrative report. 3 p. On file with: Southwest Oregon Forest Insect and Disease Service Center, J. Herbert Stone Nursery, 2606, Old Stage Road, Central Point, OR 97502.

Millar, C.I.; Marshall, K.A. 1991. Allozyme variation of Port-Orford-cedar (Chamaecyparis lawsoniana): implications for genetic conservation. Forest Science 37(4):1060-1077.

U.S. Department of Agriculture, Forest Service, California Region. 1969. California tree seed zone map. Scale 1:100000. San Francisco, CA.

U.S. Department of Agriculture, Forest Service, Pacific Northwest Region. 1973. Washington and Oregon tree seed zone maps. Scale 1:500000. Portland, OR.

Westfall, R.D.; Conkle, M.T. 1992. Allozyme markers in breeding zone designation. New Forests 6:279-309.

Zobel, D.B., Kitzmiller, J.H.; Sniezko, R.A.; Riley, L. In press. Range-wide genetic variation in Port-Orford-cedar (Cupressacease, Chamaecyparis lawsoniana): II. Timing of height growth. Journal of Sustainable Forestry. 
Zobel, D.B.; Riley, L.; Kitzmiller, J.H.; Sniezko, R.A. 2001. Variations in water relations characteristics of terminal shoots of Port-Orford-cedar (Chamaecyparis lawsoniana) seedlings. Tree Physiology 21: 743-749. 


\section{Chapter 6}

\section{Breeding For Resistance to Phytophthora lateralis}

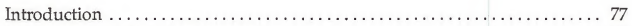

The Resistance Screening Process $\ldots \ldots \ldots \ldots \ldots \ldots \ldots \ldots \ldots \ldots \ldots, 77$

Resistance Screening Results $\ldots \ldots \ldots \ldots \ldots \ldots \ldots \ldots \ldots \ldots \ldots \ldots \ldots \ldots \ldots$

Validation of the Screening Process. . . . . . . . . . . . . . . . . . . . . 82

Common Garden Study . ................................. 83

Geographic Variation in Resistance Traits ................. 83

Phenotypic Correlations Among Traits. .................. 84

Variation in Disease Resistance at the Watershed Level .......... 84

Variation in Disease Resistance at the Breeding Zone Level........ 84

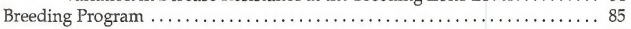

Controlled Pollination. . . . . . . . . . . . . . . . . . . . . 85

Vegetative Reproduction. . . . . . . . . . . . . . . . . . . . . . . 86

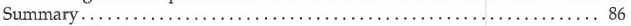

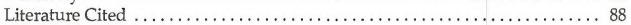

Authors: Richard A. Sniezko, Jay Kitzmiller, Leslie J. Elliott and James E. Hamlin

June 2001 
A Range-Wide Assessment of Port-Orford-Cedar on Federal Lands 


\section{Introduction}

Port-Orford-cedar lends itself exceptionally well to a program of resistance breeding. Flower production can be stimulated at an early age and establishing rooted cuttings is relatively simple, making propagation straightforward. Evaluation of some types of resistance can be done in short-term tests.

The development of populations of Port-Orford-cedar with a broad genetic base and durable resistance to Phytophthora lateralis is considered a key component to maintaining or restoring Port-Orford-cedar. Resistant Port-Orford-cedar is likely to be essential for the success of private owners who manage the species.

Early reports of infection of Port-Orford-cedar with $P$. lateralis indicated that all tested ornamental varieties, and some varieties of Chamaecyparis obtusa (Siebold and Zucc.) Siebold and Zucc. ex Endl., were susceptible while Chamaecyparis pisifera (Siebold and Zucc.) Endl. varieties showed resistance (Tucker and Milbrath 1942). Recent data indicate that several other species of Chamaecyparis are highly resistant. ${ }^{10}$

Initial results from resistance testing were discouraging. In early disease resistance tests that included cuttings from hundreds of trees that were phenotypically resistant in natural stands, all rooted cuttings died, indicating resistance was very low or that the inoculation level was too high, or both, to allow expression of resistance among the clones (Roth et al. 1972, Roth 1985, Zobel et al. 1985).

Up to the mid-1980s, occasional Port-Orford-cedar trees were found that survived infection or showed delayed death, but no attempts to breed for resistance or hybridize with resistant yellow cedar (Chamaecyparis nootkatensis) or Asiatic Chamaecyparis species had been attempted (Roth et al. 1987). A few survivors that have lived for an extended period of time in the presence of $P$. lateralis were noted in the cold frames near the Oregon State University (OSU) greenhouses and at the OSU Botany Farm, and were thought to represent some type of "slow dying" resistance (Roth 1985).

Work began in the early 1980 s to refine an inoculation system to allow susceptible and relatively tolerant individuals to be distinguished (Hansen and Hamm 1983, Hansen and Hamm 1986). In small-scale tests using 10 individuals (four that had survived previous testing with $P$. lateralis and six new ones), resistant individuals were distinguished from susceptible individuals by a slowing of the rate of advance of the disease (Hansen et al. 1989). This was a key study in confirming resistance and leading to the initiation of further investigations and the operational breeding program for resistance by the U.S. Department of Agriculture Forest Service and the U.S. Department of the Interior Bureau of Land Management (BLM). Dr. Everett Hansen at OSU has worked with the Forest Service and the BLM since the 1980s to refine techniques to be used in operational screening efforts.

\section{The Resistance Screening Process}

Starting in 1989, the Forest Service began selecting candidate Port-Orford-cedar trees in natural stands to evaluate resistance to $P$. lateralis (fig. 6.1). The BLM began making selections in 1994 (fig. 6.2). A small number of trees in natural stands were initially selected from throughout much of the species' range. In 1997, the program greatly expanded, and since that time more than 9,000 candidate trees, from both healthy and

\footnotetext{
${ }^{10}$ Sniezko, R.A. 2001. Unpublished data. On file with: U.S. Department of Agriculture, Forest Service, Dorena Tree Improvement Center, 34963 Shoreview Road, Cottage Grove, OR 97424.
} 
diseased locales, have been selected and screened for disease resistance at Oregon State University (Bower et al. 2000). These selections have not only been from federal lands, but also from county and private lands throughout the range of Port-Orford-cedar.

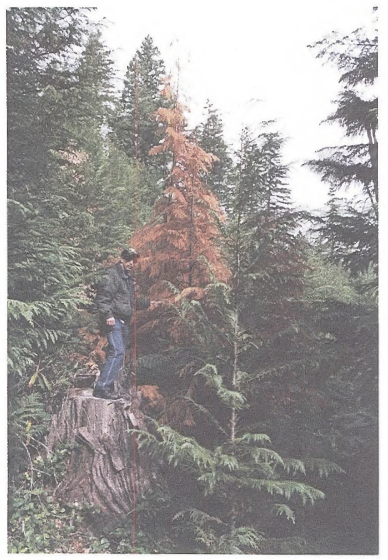

Figure 6.1-Resistant Port-Orfordcedar trees growing with infected Port-Orford-cedars, growing in a natural stand

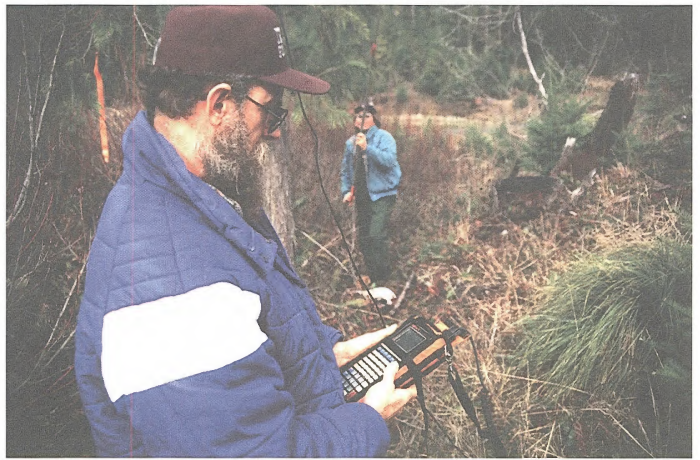

Figure 6.2-Field selection and mapping of a Port-Orford-cedar candidate tree 
In the first cycle of selection (wild selections) a candidate parent tree (or clone) is selected and branches from the tree, or seedlings from seed collected from the candidate trees (1996 only) are sent to OSU for screening in a greenhouse (fig. 6.3). The samples are inoculated with $P$. lateralis. In general, two to three isolates of $P$. lateralis have been used.

In 1989 and 1990, large branches were collected and an incision was made in the branch that was then inoculated with $P$. lateralis (wound inoculation technique). Although $P$. lateralis is a root pathogen, the branch test technique was chosen for initial work (over the root methods) because many samples could rapidly be assessed and there was at least a low positive correlation with other techniques. The top resistant parents had initially been evaluated with this technique. Since 1994, however, the procedure has been to send six to 10 small branch tips to OSU, where the cut end of the branch tips are dipped in a zoospore suspension of $P$. lateralis.

When seedlings were used for testing, notably in 1996, either the stem dip technique (immersing the bottom two centimeters of a cut portion of the seedling in a zoospore suspension) (fig. 6.4) or a root dip technique (immersing the bottom two centimeters of the container containing the seedling roots in a zoospore suspension) was used. In the stem dip technique, the length of the lesion growth on the sample stem is measured several weeks after inoculation, with lesion length representing a possible measure of resistance. For the root dip technique, time until mortality is recorded (fig. 6.5).

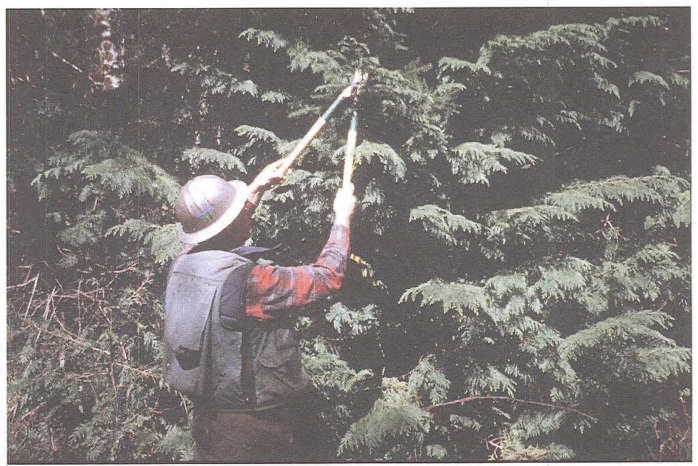

Figure 6.3-Collecting branches for resistance screening 


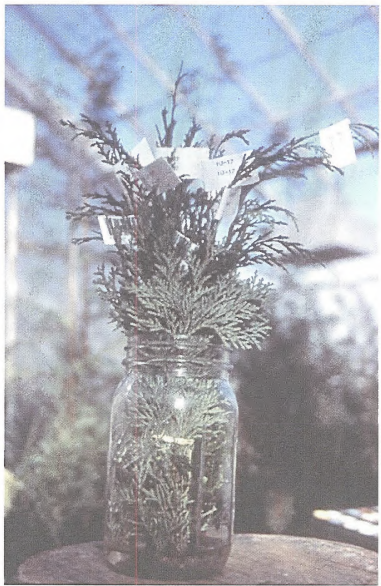

Figure 6.4-Stem dip technique for inoculating samples for testing resistance to Phytophthora lateralis

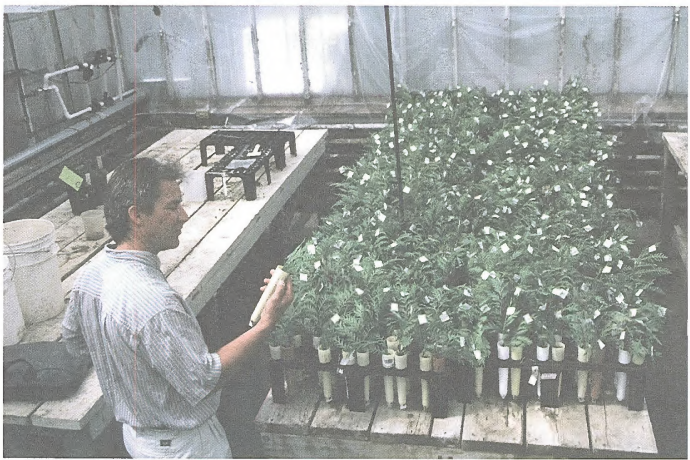

Figure 6.5-Seedlings being monitored for survival after inoculation with the root dip technique 
In general, a high resistance checklot (PO-OSU-CF1) has been included in the testing since 1993 and a low resistance checklot (PO-OSU-CON1) since 1997 to provide a basis of comparison. These checklots are used to help determine which parent trees are initially selected for the breeding program and for further testing. Due to the large number of selected trees screened since 1997, the screening has been done in many groups or "runs" spread throughout the year. The stem dip technique was chosen for the initial phase of operational screening because it allows for a rapid assessment of differences among parent trees for at least one type of resistance potential.

\section{Resistance Screening Results}

Through the year 2000, researchers have identified 1,179 potentially disease resistant trees based upon the initial phase of screening using a branch lesion test (table 6.1). For detail on screening methods used see Appendix E. The resistance identified to date in the branch lesion test is not expressed as immunity, but as reduced growth rate of the fungus in infected trees.

In screenings with different methods over the years, several clones (notably PO-OSUCF1) from Coos County in Oregon, and clone 510015 from the Gasquet Ranger District, Six Rivers National Forest in California have consistently been rated best or near the top for small lesion scores (Sniezko and Hansen 2000; Sniezko et.al. 2000). Recent seedling trials indicate that Parent 117490, from the Gold Beach Ranger District in Oregon, shows much higher resistance (percent survival) than any selection to date (table 6.2).

Based on selections prior to 1997, it appears that there are relatively few clones (perhaps 1 to 2 percent) that repeatedly stand out in all screening tests. The remainder of the clones may have resistance, but it may be more subtle and not apparent under heavy inoculum loads or without a more sensitive test. A study to examine the possible mechanisms of resistance has been initiated and may provide insight to a more definitive evaluation of resistance.

Table 6.1-Number of Port-Orford-cedar selections for breeding from initial resistance screening

\begin{tabular}{|c|c|c|c|c|c|c|c|c|c|c|}
\hline & \multicolumn{10}{|c|}{ Number of Selections Tested } \\
\hline & 1989 & 1990 & 1995 & 1996 & 1997 & 1998 & 1999 & 2000 & 2001 & Total \\
\hline Medford BLM & & & 20 & 30 & 99 & 4 & 19 & & 6 & 178 \\
\hline Roseburg BLM & & & & & 30 & 13 & 2 & & 5 & 50 \\
\hline Coos Bay BLM & & & & 10 & 39 & 112 & 20 & & 1 & 182 \\
\hline Salem BLM & & & & & & & & & 1 & 1 \\
\hline FS Siskiyou NF & 10 & 40 & & 28 & 203 & 121 & 21 & & & 423 \\
\hline FS Siuslaw NF & & & & & & & 5 & & & 5 \\
\hline FS California & & & & & & & & & $6^{*}$ & 6 \\
\hline FS Klamath NF & & & & & 3 & 10 & 3 & & & 16 \\
\hline FS Six Rivers NF & 3 & 10 & & 34 & 3 & 3 & 1 & 2 & 2 & 56 \\
\hline FS Shasta-Trinity NF & & & & 27 & & & 1 & & & 28 \\
\hline Non-federal Lands & & & & 19 & 6 & & 152 & 8 & 49 & 234 \\
\hline Total & 13 & 50 & 20 & 148 & 383 & 263 & 224 & 10 & 68 & 1179 \\
\hline
\end{tabular}

*Specific National Forest (NF) information not available in database as of 3/17/03 
Table 6.2-Percent mortality after one year for three test methods for six of 44 open-pollinated seedling families tested in 2000

\begin{tabular}{cccc}
\hline Parent & $\begin{array}{c}\text { Greenhouse Root } \\
\text { Dip (OSU) }\end{array}$ & $\begin{array}{c}\text { Test Location } \\
\text { Raised Bed (OSU) }\end{array}$ & $\begin{array}{c}\text { Camas Valley (BLM } \\
\text { Field Site) }\end{array}$ \\
\hline 117490 & 0 & 38.9 & 8.3 \\
510005 & 25.0 & 33.3 & 0 \\
CF1 & 50.0 & 50.0 & 25.0 \\
117499 & 83.3 & 66.7 & 50.0 \\
510044 & 66.7 & 75.0 & 75.0 \\
70102 & 100 & 91.7 & 100 \\
\hline
\end{tabular}

\section{Validation of the Screening Process}

Greenhouse screening techniques developed at OSU, such as the stem and root dip techniques, are methods to survey many candidate trees quickly for an indication of relative resistance. Artificial inoculation and subsequent assessment is quicker, less expensive, and more controllable than field plantings. Little is known, however, about how these measures relate to resistance in the field and how much longer the more resistant seedlings may survive under field conditions. OSU established a small field planting in 1989, while plantings have been established by the Forest Service and BLM since 1993 to validate screening methods and examine the durability and types of resistance (Sniezko and Hansen 2000). Although current evidence indicates that there is little genetic variation in P. lateralis (see Chapter 3), these plantings will allow tested material to be evaluated and compared under a range of conditions. Using this information, a more comprehensive comparison between field and greenhouse results can then be made.

In 1999, the process of re-testing the initial stem dip selections using the root dip technique began. Results from the first parents tested using rooted cuttings showed that a subset appears to have resistance comparable to the high resistance control (CF1). Preliminary testing in 1996 showed only a low positive correlation between the stem and root dip methods (Appendix E). This second phase of testing will either: (a) establish a sufficient correlation between the stem and root dip techniques to validate the initial screening results, or (b) provide a further screening of the initial selections.

Field plantings have demonstrated that rooted cuttings or open-pollinated seedlings from some of the parents showing high resistance to $P$. lateralis (in the initial branch and stem dip testing process) have much higher survival than those of the parents rated low for resistance (fig. 6.6). Most of the mortality in the field tests appears to occur in the first two years. Microsite variation can be substantial and may contribute to early mortality. Eleven years after planting, rooted cuttings from the most resistant parents have shown 50 to 80 percent survival in the field (Sniezko and Hansen 2000, Sniezko et al., n.d.), while cuttings from nonresistant parents have generally shown 0 to 5 percent survival; in the earliest tests open-pollinated seedlings from the most resistant parents have shown 25 to 50 percent survival versus 0 to 35 percent for other parents. Detail on validation plantings is presented in Appendix F. 


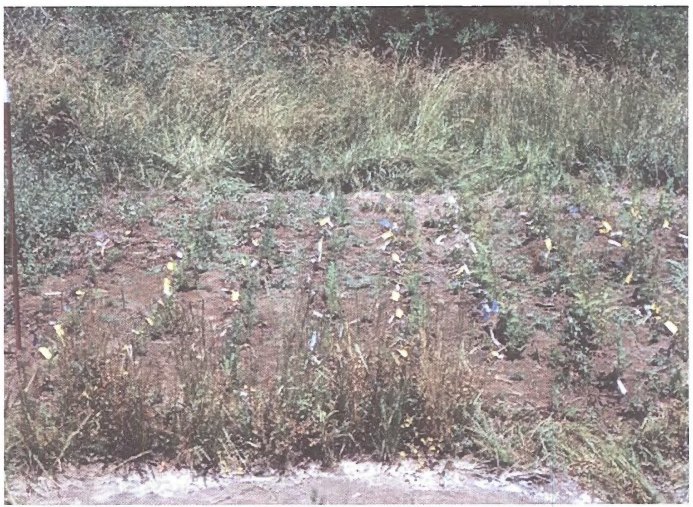

Figure 6.6 - Field plantings of high resistance genotypes

\section{Common Garden Study}

Common garden studies are sites where the same genetic stock is planted across a range of different sites that vary in elevation and latitude and longitude. As stated in Chapter 5, a common garden study using range-wide material was established in 1996 to evaluate the genetic variability of Port-Orford-cedar (Kitzmiller and Sniezko 2000). This study examined both height growth and disease resistance traits. Disease resistance was evaluated using two methods: (1) a stem dip test where branch tips from a selected tree were dipped in a zoospore suspension of $P$. lateralis and (2) a root dip test where a seedling's roots were immersed in a zoospore suspension. Details on study design are presented in Chapter 5.

\section{Geographic Variation in Resistance Traits}

Compared to height growth, disease resistance traits (based upon stem and root dip tests) showed much weaker, though significant, geographic patterns of variation. This is not surprising because the disease has apparently spread only recently into the native range of Port-Orford-cedar. There has not been sufficient time of coexistence of host and pathogen to co-evolve a strong geographic pattern across the range of habitats. To assess the overall geographic pattern, height growth plus disease resistance variables were combined in a canonical correlation analysis with three geographic origin variables (latitude, longitude, and elevation) expressed in a full quadratic model. Comparing the amount of variation explained by geographic factors for allozyme diversity and the amount of variation explained for common garden height growth, (Millar et al. 1992, unpublished range-wide study), $R 2=13.5$ percent for the former and R2 $=75$ percent for the latter. Clearly the geographic variation pattern is far greater for height than for allozymes. 
In a 1996 test of random parents (not selected for field test resistance) from much of the range of Port-Orford-cedar, patterns of variability differed both at the stand and watershed level.

Root test resistance showed greater geographic variation than stem test resistance, and was almost opposite for geographic pattern. Root test resistance decreased from the coast to inland sites, and to a lesser degree, from north to south. Root test resistance was higher for the moist northern and coastal sources and was lower for the drier southern and inland sources. Stem test resistance increased from north to south. Southern latitude sources had smaller stem lesions than northern latitude sources. Stem test resistance increased with increasing elevation of a source and with distance from the coast. Further investigation is needed, but these trends may indicate that some parts of the range of Port-Orford-cedar may have a higher frequency of resistance and/or that different resistance mechanisms may be in higher frequency in parts of the species range.

\section{Phenotypic Correlations Among Traits}

For root test resistance, on a stand mean basis, 10 percent of the variation was positively associated with early height growth. For stem test resistance, on a stand mean basis, eight percent of the variation was negatively associated with early height growth (two percent on family mean basis). Thus, to a small but significant extent, stands and trees that grow fast tend to possess higher root test resistance. To a lesser extent, stands and trees that grow slow tend to possess higher stem test resistance.

For stand means the correlation between root test resistance and stem test resistance was non-significant. Thus, stands cannot generally be found to have both types of resistance. However, a small but significant portion of families may have both types of resistance.

\section{Variation in Disease Resistance at the Watershed Level}

The genetic component for root test resistance accounted for 58.6 percent of the total variability: watersheds 14.1 percent, stands within watershed 7.5 percent, and families within stand within watershed accounted for 37 percent. All three were highly significant. Blocks and random plot error made up the remaining variability.

For stem test resistance, the genetic component was small (14.3 percent of the total). Like root test resistance, the families within stand within watershed component ( 9.7 percent) for stem test resistance was much greater than the watershed ( 2.5 percent) and stand (2.1 percent, non-significant) components. Blocks and plot error made up the majority ( 85.7 percent) of the total variability for stem-test resistance.

Therefore, the genetic basis for root test resistance is far greater than it is for stem test resistance, and resistance varies mostly from family to family within a watershed. By contrast, for height growth the watershed component was several times greater than the families within stand within a watershed.

\section{Variation in Disease Resistance at the Breeding Zone Level}

A slightly larger portion of the total variability (61 percent) is attributed to breeding zones (see Chapter 5 for a discussion of breeding zones) than to watersheds. Breeding zones accounted for 18.1 percent and seed zones within breeding zones were nonsignificant at 2.4 percent. Families within seed zones within breeding zones were by far the most variable at 40.3 percent of the total. For stem test resistance, neither breeding 
zones nor seed zones were significant. Families within zones accounted for 11.9 percent of the total variability, and blocks plus plot error contributed the majority ( 85.5 percent).

\section{Breeding Program}

In the early 1990s, the Forest Service and BLM began a breeding program with PortOrford-cedar to attempt to increase resistance to $P$. lateralis. This species lends itself exceptionally well to a program of resistance breeding (Elliott and Sniezko 2000) because it is easily propagated. Propagation techniques used at Dorena Tree Improvement Center, Cottage Grove, Oregon, are described below.

\section{Controlled Pollination}

Port-Orford-cedar can be induced to flower at most times of the year as long as they are not dormant. Growth hormones, such as gibberellins, can be used to induce flowering, and in combination with photoperiod at the timing of treatment(s), can be used to effectively influence the relative amounts of male and female flowering (Zobel et al. 1985). Flowering in Port-Orford-cedar can be induced in trees less than one year old.

Controlled pollination is an essential part of the breeding and resistance-screening program at Dorena Tree Improvement Center (DTIC). The process is summarized below.

To stimulate cone production in young material, a foliar spray application of gibberellic acid (GA3) is applied in June. The treatment is applied weekly, over a five-week period, at a rate of $100 \mathrm{mg}$ of GA3 per liter of water. Large increases in strobili are generally evident the year following treatment. Large clonal differences exist in the amount of strobili produced (Elliott and Sniezko 2000).

Pollen is shed (at Dorena) from late February through mid-A pril (fig. 6.7). Pollen is collected and dried for 24 to 48 hours at 15 to $20 \mathrm{C}$ and 20 to 40 percent relative humidity. For short-term storage, pollen is refrigerated with a desiccant. For long-term storage, pollen is stored in a freezer at -14 C. The average viability of pollen collected in 1997 and 1998 was 51 and 72 percent, respectively. There was a large clonal variation in viability, with a range from zero to 93 percent. Storage up to two years does not appear to significantly reduce viability.

Figure 6.7-Pollen shed by PortOrford-cedar growing at Dorena Tree Improvement Center, Cottage Grove, Oregon

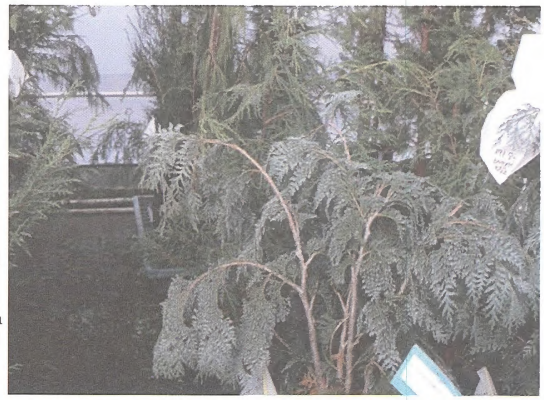


Controlled pollination is initiated at the first sign of receptivity by the female strobili (pollen drop). Because of the variability in timing of receptivity, two pollinations are usually attempted for each cross within a four to seven day period. Although there is clonal variability, observation shows the majority of pollen shedding occurs a week ahead of the time when most female strobili become receptive on the same tree (which would minimize natural self-pollination).

Conelet abortion may be substantial during the development period (March through September). For example, in 1997, there was a 30 percent conelet abortion rate at DTIC. In 1997 through 1999 the overall average percent filled seed from control crossings ranged from 40 to 50 percent and the average filled seed per cone ranged from 5.0 to 6.2 .

Selfing (breeding an individual with itself) does produce viable seed. However, at DTIC, a reduction in percent filled seed and number of seeds per cone has been evident. For example, in 1997, selfing produced an average of 22 percent (range, 0 to 76 percent) filled seed, while outcrosses produced an average of 51 percent (range, 0 to 94 percent). Selfing averaged 2.8 filled seeds per cone (range, 0 to 11.7 ) and outcrosses, 6.7 filled seeds per cone (range 0 to 11.2).

\section{Vegetative Reproduction}

Cuttings from Port-Orford-cedar are easily rooted. For example, at DTIC, in 1998, 96 percent of the 330 clones where rooting was attempted were successfully rooted. Rooting time varied for seedlings, and ranged from 3 to 12 months. Rooting success and times vary with age; younger material roots more readily. Rooting success is improved if material is collected when it is dormant or has slowed growth (November through February). Cuttings from major branches in the lower portion of the crown are preferred (Zobel 1990a).

\section{Summary}

Port-Orford-cedar is the species most adversely affected by P. lateralis. While preliminary results from the breeding and testing efforts indicate there may be sufficient levels of resistance within Port-Orford-cedar to begin a breeding program, other avenues are also being examined. A preliminary screening of several other species and hybrids has begun to evaluate their resistance and learn more about resistance mechanisms and their inheritance.

A containerized seed orchard was established at the Dorena Tree Improvement Center, with material from the more resistant selections from the screening process (fig. 6.8). The goal of the breeding program includes developing durable resistance as well as keeping diverse genetic populations available to ensure general adaptation throughout the native range of Port-Orford-cedar. A preservation orchard was established in 1998 at the BLM Tyrrell Seed Orchard in Lorane, Oregon to also help maintain diverse genotypes. Excellent inter-regional and interagency cooperation as well as input from other groups, coupled with current knowledge of the biology of Port-Orford-cedar and resistance to the exotic pathogen, $P$. lateralis, should allow for rapid progress in evaluating and potentially developing resistant populations. Flower production can be stimulated at an early age and establishing rooted cuttings is relatively simple. Control pollinations on earlier selections began in 1996 and the full-sibling progenies are now undergoing resistance testing. 


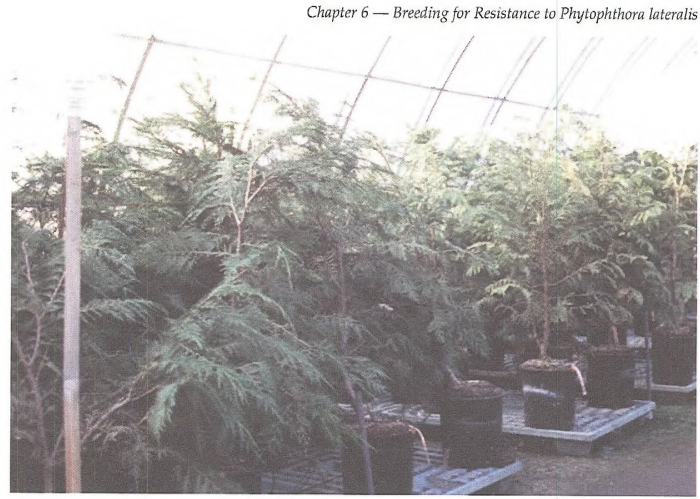

Figure 6.8-Containerized seed orchard at the Dorena Tree Improvement Center, Cottage Grove, Oregon

The operational breeding program for $P$. lateralis resistance is still young; however, results from recent testing and the biology of Port-Orford-cedar lead one to be cautiously optimistic of the potential for developing durable resistance. Only a few parents from the initial stem dip screening process have been identified with resistance sufficient to consider for immediate regeneration and restoration plantings; however, since 2000 the number of parents has been increasing dramatically as results from root dip testing and field validations are finalized. Additional resistant parents are likely to be identified based on results from current trials and additional information on the mechanisms of resistance. The use of containerized orchards allows easy upgrading of the orchards for genetic diversity and resistance as more testing is completed. Orchards can be established by breeding zones to help ensure localized adaptability. Some resistance mechanisms may not be 'strong' enough to be durable in the field without further breeding. Breeding can increase the overall resistance and incorporate any appropriate resistance mechanisms.

New data are being generated rapidly from the resistance-breeding program. Updates are presented at scientific meetings and overviews posted on the Dorena website: www.fs.fed.us/r6/dorena. A breeding program can provide sufficient quantities of seed to meet the demand of public and private organizations for highly resistant seedlings. Subsequent efforts could concentrate on making resistant seed available for additional breeding zones, increasing both the genetic diversity of the orchards and level of resistance. An additional benefit of the program could be to make resistant material available to the horticulture industry where Port-Orford-cedar was once a significant contributor in the Pacific Northwest.

Genetic resistance is one tool in the overall management strategy for Port-Orford-cedar and is best used in conjunction with other management tools mentioned elsewhere in this document. 


\section{Literature Cited}

Bower, A.D.; Casavan, K; Frank, C.; [et al]. 2000. Screening Port-Orford-cedar for resistance to Phytophthora lateralis: results from $7000+$ trees using a branch lesion test. In: Hansen and Sutton, eds. Proceedings of the first international meeting on Phytophthoras in forest and wildland ecosystems, IUFRO Working Party 7.02.09. Corvallis, OR: Oregon State University, Forest Research Laboratory: 99-100

Elliott, L.; Sniezko, R.A. 2000. Cone and seed production in Port-Orford-cedar container orchard. In: Hansen and Sutton, eds. Proceedings of the first international meeting on Phytophthoras in forest and wildland ecosystems, IUFRO Working Party 7.02.09. Corvallis, OR: Oregon State University, Forest Research Laboratory: 105-106.

Hansen, E.M.; Hamm, P.B. 1983. Resistance screening of Port-Orford-cedar to Phytophthora lateralis root rot. Corvallis, OR: Oregon State University. Unpublished report. $17 \mathrm{p}$. On file with: Southwest Oregon Forest Insect and Disease Service Center, J. Herbert Stone Nursery, 2606, Old Stage Road, Central Point, OR 97502.

Hansen, E.M.; Hamm, P.B. 1986. Screening Port-Orford-cedar for resistance to Phytophthora lateralis. Corvallis, OR: Oregon State University. Unpublished report. 26 p. On file with: Southwest Oregon Forest Insect and Disease Service Center, J. Herbert Stone Nursery, 2606, Old Stage Road, Central Point, OR 97502.

Hansen, E.M.; Hamm, P.B.; Roth, L.F. 1989. Testing Port-Orford-cedar for resistance to Phytophthora. Plant Disease 73(10):791-794.

Kitzmiller, J.H.; Sniezko, R.A. 2000. Range-wide genetic variation in Port-Orford-cedar (Chamaecyparis lawsoniana [A. Murr.] Parl.). I. Early height growth at coastal and inland nurseries. Frontiers of Forest Biology: Proceedings of the 1998 joint meeting of the North American Forest Biology Workshop and the Western Forest Genetics Association. Journal of Sustainable Forestry. 10:57-67.

Millar, C.I.; Delany, D.L.; Westfall, R.D. 1992. Genetic diversity in Port-Orford-cedar: range-wide allozyme study. Administrative report. 4 p. On file with: Southwest Oregon Forest Insect and Disease Service Center, J. Herbert Stone Nursery, 2606, Old Stage Road, Central Point, OR 97502.

Roth, L.E. 1985. Inoculation methods for quantitatively evaluating the response of Port-Orford-cedar trees to Phytophthora lateralis. Corvallis, OR: Oregon State University. Unpublished report. 26 p. On file with: Southwest Oregon Forest Insect and Disease Service Center, J. Herbert Stone Nursery, 2606, Old Stage Road, Central Point, OR 97502.

Roth, L.F.; Bynum, H.H.; Nelson, E.E. 1972. Phytophthora root rot of Port-Orford-cedar. Forest Pest Leaflet 131. Portland, OR: U.S. Department of Agriculture, Forest Service, Pacific Northwest Forest and Range Experiment Station. 7 p.

Roth, L.E.; Harvey, R.D. Jr.; Kliejunas, J.T. 1987. Port-Orford-cedar root disease. Forest Pest Management Report No. R6 FPM-PR-294-87. Portland, OR: U.S. Department of Agriculture, Forest Service, Region 6.11 p.

Sniezko, R.A.; Hansen, E.M. 2000. Screening and breeding program for genetic resistance to Phytophthora lateralis in Port-Orford-cedar (Chamaecyparis lawsoniana): early results. In: Hansen and Sutton, eds. Proceedings of the first international meeting on Phytophthoras in forest and wildland ecosystems, IUFRO Working Party 7.02.09. Corvallis, OR: Oregon State University, Forest Research Laboratory: 91-94. 
Sniezko, R.A.; Hansen, E.M.; Kitzmiller J.H.; and Hamlin J. [N.d.]. Range-wide genetic variation in Phytophthora lateralis resistance in Chamaecyparis lawsoniana. Manuscript in preparation. Dorena, OR: U.S. Department of Agriculture, Forest Service, Dorena Genetic Resource Center. On file with: Southwest Oregon Forest Insect and Disease Service Center, J. Herbert Stone Nursery, 2606, Old Stage Road, Central Point, OR 97502.

Tucker, C.M.; Milbrath, J.A. 1942. Root rot of Chamaecyparis caused by a species of Phytophthora. Mycologia. 34:94-103.

Zobel, D.B. 1990. Chamaecyparis lawsoniana (A. Murr.) Parl., Port-Orford-cedar. In: Burns, R.M.; Honkala, B.H., tech. coords. Silvics of North America: conifers. Agricultural handbook 654. Washington, DC: U.S. Department of Agriculture Forest Service. Vol. 1: 88-96.

Zobel, D.B.; Roth, L.F.; Hawk, G.M. 1985. Ecology, pathology, and management of PortOrford-cedar (Chamaecyparis lawsoniana). General Technical Report PNW-184. Portland, OR: U.S. Department of Agriculture, Forest Service Pacific Northwest Forest and Range Experiment Station. $161 \mathrm{p}$. 
A Range-Wide Assessment of Port-Orford-Cedar on Federal Lands 


\section{Chapter 7}

\section{Economic Value of Port-Orford-Cedar}

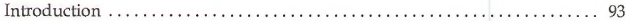

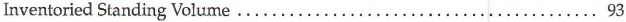

Effects of the Northwest Forest Plan . . . . . . . . . . . . . . . . . . . . . 94

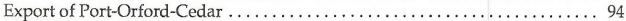

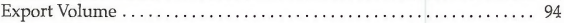

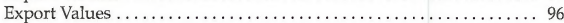

Domestic Use of Port-Orford-Cedar . . . . . . . . . . . . . . . . . . . 97

Domestic Volume . . . . . . . . . . . . . . . . . . . . . . . 98

Domestic Value . . . . . . . . . . . . . . . . . . . . . . . . 98

Combined Export and Domestic Volume and Value . . . . . . . . . . . . . 98

Value Added Components . . . . . . . . . . . . . . . . . . . . . . . . 99

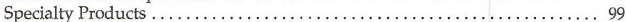

Arrow Shafts. . . . . . . . . . . . . . . . . . . . . . . . . . 99

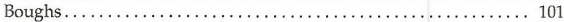

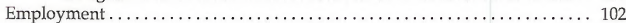

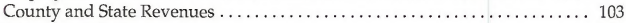

Literature Cited ..................................... 104

Authors: Richard N. Barnes and Claude C. McLean

February 1999 
A Range-Wide Assessment of Port-Orford-Cedar on Federal Lands 


\section{Introduction}

Port-Orford-cedar is a commercial conifer tree in southwestern Oregon and northwestern California. In the past, it has commanded prices as high as $\$ 12,000$ per thousand board feet. It is a valuable timber resource and has impacts on the economy in the Pacific Northwest. This chapter will explore those impacts.

\section{Inventoried Standing Volume}

The inventory of standing volume of Port-Orford-cedar is difficult to ascertain. PortOrford-cedar is a minor species in most stands where it occurs and is often located in isolated pockets. The inventory information has a high level of uncertainty because inventory of neither public nor private ownerships has been conducted at an intensity level that provides a high degree of accuracy. As a result, all inventory information presented here has a high probability of some degree of error.

Table 7.1 displays the most current information for the federal inventories of Port-Orfordcedar, as well as the inventories reported in Stuntzer (1991). The latter is volume from lands considered at the time to be in the timber base and available for harvest. The 1998 inventories are shown for all land. The volume estimates have not been reduced for designations such as the Smith River National Recreation Area or the Northwest Forest Plan (NFP) (USDA and USDI 1994).

The inventory of Port-Orford-cedar on private lands is not possible to estimate with any degree of reliability and has not been attempted here. Most of the major private landowners are unwilling to disclose this proprietary information. Historically, due to the high value of Port-Orford-cedar, there has been a tendency to harvest the species at a higher rate than is proportional to forest stocking level (Zobel 1986). As a result of these practices, most of the Port-Orford-cedar on private lands today is second growth.

Table 7.1-Port-Orford-cedar inventory from Forest Service and Bureau of Land Management (BLM) lands

\begin{tabular}{lccc}
\hline \multirow{2}{*}{ Agency } & \multicolumn{2}{c}{ Inventoried Port-Orford-cedar Volume (mbf) } \\
\hline & $1990^{*}$ & $1994^{* * *}$ & $1998^{* * * *}$ \\
\cline { 2 - 4 } & & 117 & 121 \\
BLM - Coos Bay & 8 & 8 \\
BLM - Roseburg & 10 & 10 \\
BLM - Medford & 240 & & 422 \\
Siskiyou National Forest & 87 & & 420 \\
Six Rivers National Forest & 17 & & 75 \\
Klamath National Forest & & & \\
Shasta-Trinity National Forest & & & \\
*from Stuntzer 1991; land considered to be in the timber base \\
**Coos Bay and Roseburg figures from Brattain and Stuntzer 1994; Medford figures from February 1994 \\
continuous forest inventory \\
$* *$ short log volumes; all land allocations
\end{tabular}




\section{Effects of the Northwest Forest Plan}

Implementation of NFP has reduced timber sale levels in southwestern Oregon and northwestern California well below previous levels projected by forest plans and resource management plans of the Forest Service and Bureau of Land Management (BLM). The NFP reduces volumes to approximately 17 percent of the prior sales levels. The volumes shown as available for harvest are likely to be over-estimates, since the agencies have had trouble meeting the NFP sale volumes. In addition to lands contained in Wilderness Areas and other congressional set-asides, lands designated by the NFP as Late-Successional Reserves (LSR), with an objective to protect and enhance the conditions of late successional and old-growth forest ecosystems which serve as habitat for late-successional and old-growth forest related species, and Riparian Reserves, with objectives including stream protection and landscape connectivity, limit volume that may be harvested. Many of the inventoried high quality Port-Orford-cedar trees are in LSRs. Also, Riparian Reserves, with widths up to two tree heights on each side of the stream, have been established. In some locations, Riparian Reserves encompass much of the moist habitat where Port-Orford-cedar may be found.

\section{Export of Port-Orford-Cedar}

\section{Export Volume}

The first commercial shipment of Port-Orford-cedar lumber left Port-Orford, Oregon, in 1854, and harvest probably went on regularly after the first settlement there in 1851 (Zobel 1986). A significant portion of this harvest has been exported to Japan, the People's Republic of China and South Korea, with the majority going to Japan (Warren 1998).

The data for export volumes are based on U.S. Department of Agriculture Forest Service and Pacific Northwest Research Station information for all ports in the Columbia Snake Customs District, including all Oregon ports and the ports of Longview and Vancouver, Washington (Warren 1998). Added to these, are the Port-Orford-cedar volumes shipped out of Humboldt Bay, California, using data supplied by Humboldt Bay Forest Products, Inc.

Export volumes declined between 1961 and 1998. The volume exported in 1963 was 64 million board feet. This declined to 3 million board feet in 1997 (fig. 7.1) (USDA 1973, Warren 1985, Warren 1998). During the 1990s the amount of Port-Orford-cedar volume exported continually decreased. In 1996, the amount reached its lowest level of the period, at 1.5 million board feet. In 1997, the export volumes reversed the trend and increased from the previous year by 700 thousand board feet. Indications are that final export volumes for 1998 will be slightly higher than 1997. The overall decline in export volume may be attributed to reduced harvest of old-growth Port-Orford-cedar.

During the 1990s, Port-Orford-cedar harvest was heavily concentrated on private lands (fig. 7.2), and most of the timber came from second growth stands. As a result, a substantial amount of second growth Port-Orford-cedar was exported during the $1990 \mathrm{~s}^{11}$ The trend toward second growth, combined with the Japanese market conditions, has resulted in a movement away from exports and towards domestic use. ${ }^{12}$

\footnotetext{
"Lyon, Frank. 1998. Personal communication. Timber Manager. Menasha Corporation, P.O. Box 588, North Bend, OR 97459.

${ }^{12}$ Data were taken from the Yield Tax information, California Board of Equalization, for public and private lands; the Western Oregon Privilege Tax information, Oregon Department of Revenue, for private lands; and the Siskiyou National Forest, Roseburg, Coos Bay and Medford BLM (Kirk Casavan, Roseburg BLM); and Coos County (Robert LaPort, County Forester) for public lands. On file with: Barnes and Associates, 3000 NW Stewart Parkway \# 204, Roseburg, OR 97470.
} 
Historical Export of Port-Orford.Cedar

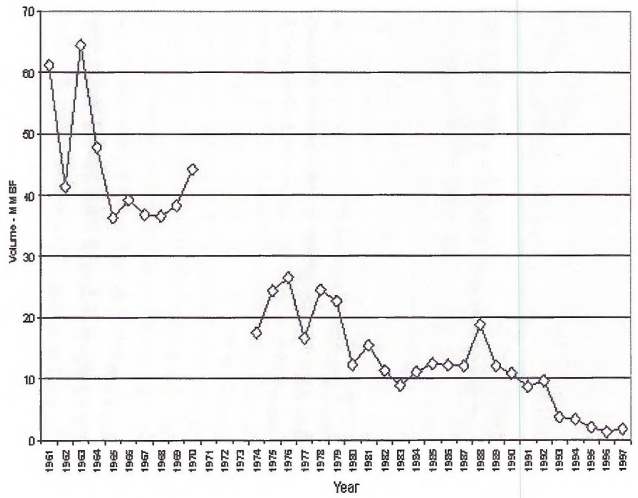

Figure 7.1-Volume of Port-Orford-cedar exported 1961 - 1997

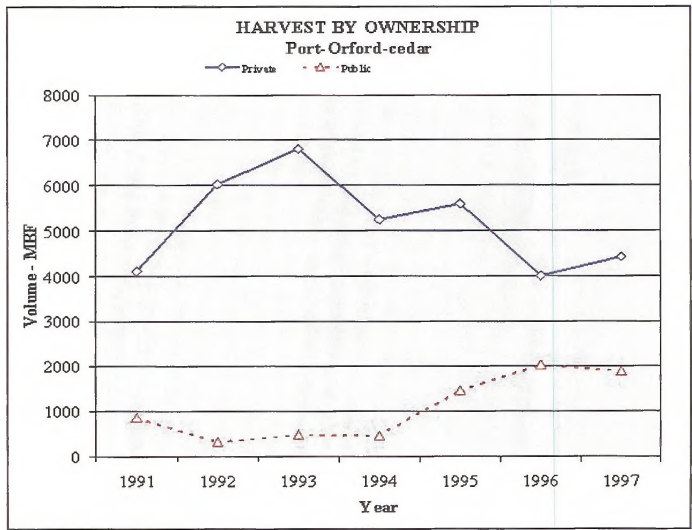

Figure 7.2-Harvest levels by ownership sector in the United States 


\section{Export Values}

The Japanese have placed a high value on Port-Orford-cedar for many years. Although these values fluctuated substantially during the 1990 s, they continue to be much higher than the values on the domestic market (figs. 7.3 and 7.4). Export values per thousand board feet (MBF) began the 1990s averaging $\$ 2,672$, reached a low in 1992 at $\$ 1,947$, then increased dramatically in 1994 to $\$ 5,645$ (per MBF). The higher grades of Port-Orfordcedar were selling for approximately $\$ 10,000$ per MBF with occasional sales exceeding this value ${ }^{13}$. In 1997, the average value of Port-Orford-cedar logs exported was $\$ 2,944$ per MBF. It is important to note, even with the tremendous drop in export values from 1994 to 1997, the 1997 values are still higher than the average values during 1990 through 1992. Export values have been volatile (fig. 7.3).

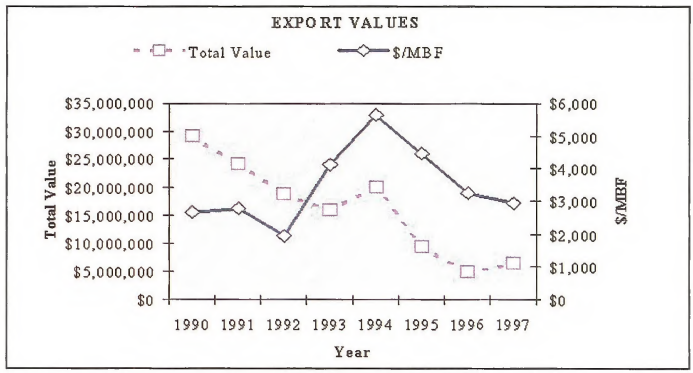

Figure 7.3-Value of exported Port-Orford-cedar 1990 - 1997

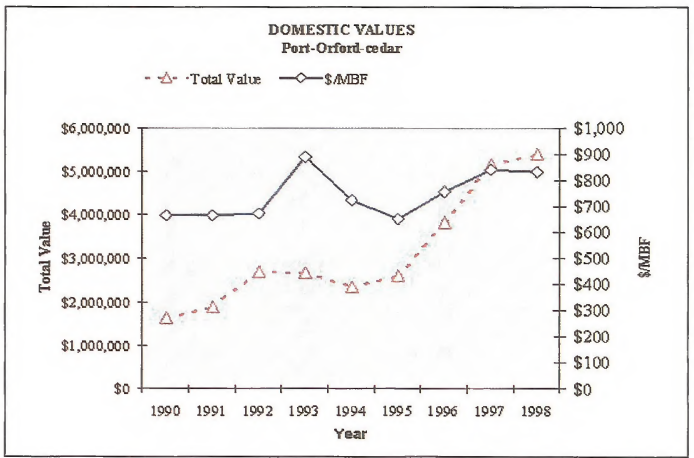

Figure 7.4-Domestic values of milled Port-Orford-cedar $1990-1998^{14}$

\footnotetext{
${ }^{13}$ Currie, Jim. 1998. Personal communication. Currie Log Marketing, 2159 Parkway Drive, Crescent City CA 95531.
} 
The drop in volume of Port-Orford-cedar harvested was the driving force in the reduction in total export value during the 1990s. The total volume exported in 1997 was 20 percent of the volume exported in 1990. Correspondingly, the total value of PortOrford-cedar exported in 1997 was 22 percent of the total volume exported in 1990.

Other factors, in addition to the drop in old-growth harvest, impacted the Japanese market. A cultural change there has resulted in a younger generation unwilling to pay exorbitant prices for Port-Orford-cedar. ${ }^{15}$ The older generation valued the wood highly for such things as temples or luxury items. An additional possible cause of reduced exports may be the poor Japanese economy. The Port-Orford-cedar market may recuperate when the Japanese economy recovers. ${ }^{16}$

The total value of Port-Orford-cedar logs exported was approximately \$29 million in 1990 , then dropped steadily to a low of $\$ 4.9$ million in 1996 . By 1997 , the total value of Port-Orford-cedar had risen slightly to $\$ 6.5$ million.

In summary, the decrease in availability of Port-Orford-cedar (particularly old-growth), the depressed Japanese economy, and changing Japanese cultural values, are all impacting export values and volumes. Even though the export values have decreased substantially, they are still at least three times higher than the domestic market values.

\section{Domestic Use of Port-Orford-Cedar}

By the middle of the nineteenth century, the rapidly expanding population of California created an increasing domestic demand for wood, including Port-Orford-cedar which was the most expensive and useful. Harvest levels increased throughout the rest of the $1800 \mathrm{~s}$. From the 1920s until World War

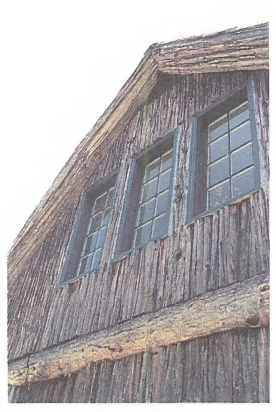
II, Port-Orford-cedar harvest levels were booming (fig. 7.5). One of the primary uses of Port-Orford-cedar was for the production of automobile storage batteries. In a single year, 1936, 1 billion wooden battery

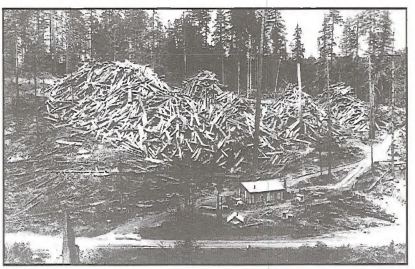

Figure 7.5-Logging decks of Port-Orford-cedar in the Coquille area of Oregon, 1939. The photo was marked on the back with the caption "Left all the old growth fir, took only cedar." Photograph Courtesy Douglas County Museum, Negative No. 14085. separators were made in Coos Bay, Oregon. By the late 1940s, however, substitute materials had been developed, and demand for Port-Orford-cedar quickly declined (Zobel et al. 1985).

Since the mid-1980s, domestic manufacturing and use of Port-Orford-cedar has increased. The species is marketed for its strength, durability, and versatility, and is used for paneling, decking, fence posts and fence rails (fig. 7.6). Some Port-Orford-cedar is milled into cants for export to Japan.

Figure 7.6-A cabin built of Port-Orford-cedar near Powers, Oregon

\footnotetext{
${ }^{14}$ Data for domestic log utilization and values were obtained from: Schroeder, Gary. Timber Manager. C \& D Lumber Company, 1182 Pruner Road / PO Box 27, Riddle, OR $97469 . ;$ Keller, Mike, Log Buyer. Keller Lumber Company, 4418 Keller Road, Roseburg, OR 97470. Goirigolzarri, Javier. P \& M Cedar Products, P.O. Box 7349, Stockton, CA 95267. Standley, Cyrus. Timber Manager. Glide Lumber Products, 1577 Glide Loop Dr, Glide, OR 97443; and Sproul, Bob. Owner. East Fork Lumber Company, P.O. Box 275, Myrtle Point, OR 97458.

${ }^{15}$ Green, Fred. 1998. Personal communication. Reservation Ranch, Coos Bay, OR.

${ }^{16}$ Green, Fred. 1998. Personal communication. Reservation Ranch, Coos Bay, OR.
} 
Currently, the major manufacturers of Port-Orford-cedar lumber are located in Oregon. The primary manufacturers are C \& D Lumber Company in Riddle, Keller Lumber Company and P \& M Cedar in Roseburg, Glide Lumber Products in Glide, and East Fork Lumber Company in Myrtle Point.

C \& D Lumber Company has aggressively marketed Port-Orford-cedar since the mid1980s. Brochures have been produced showing the benefits of Port-Orford-cedar over other products. Most notably, Port-Orford-cedar outperforms western red cedar, incense cedar, redwood, and ponderosa pine when impact bending, crushing strength (parallel and perpendicular to grain), shearing strength (parallel to grain) and side hardness (perpendicular to grain) are analyzed. For example, Port-Orford-cedar is 45 percent stronger than redwood or western red cedar in impact bending and 30 percent stronger in crushing strength.

\section{Domestic Volume}

In 1990, there was approximately 2.5 million board feet of Port-Orford-cedar lumber domestically processed. This rate increased throughout the decade and reached 6.5 million board feet in 1998. This increase may be largely attributed to the success of the manufacturers' marketing campaigns and the resultant acceptance of Port-Orford-cedar in the domestic market.

\section{Domestic Value}

The value of Port-Orford-cedar fluctuated in the 1990s. The average value of a delivered $\log$ was $\$ 665$ per $\mathrm{MBF}$ in 1990 , and $\$ 834$ per $\mathrm{MBF}$ in 1998 . The total delivered log value increased substantially, from $\$ 1.6$ million in 1990, to $\$ 5.4$ million in 1998 (fig. 7.4).

\section{Combined Export and Domestic Volume and Value}

Prior to 1994, the export volume always exceeded the domestic volume. Since 1994, the trend has reversed. Total volume was at a low in 1995, at 6.1 million feet and has increased since that time. In 1997, the total volume was approximately 8.4 million board feet.

The total value decreased from 1990 to 1996 . The 1997 value, $\$ 11.7$ million, was about a third of the 1990 value of $\$ 30.8$ million. The export and domestic values were nearly equal in 1997 (fig. 7.7).

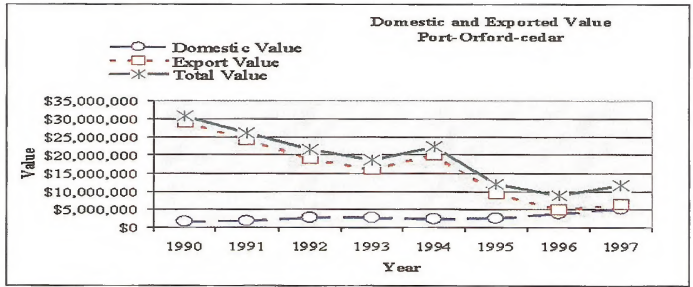

Figure 7.7-Value of domestic and exported Port-Orford-cedar 1990-1997 


\section{Value Added Components}

In addition to the volumes and values shown in previous graphs, there are value added components to be recognized. For export logs, there is approximately $\$ 100$ per MBF additional cost once the logs reach the log yard. These include costs associated with unloading trucks, log scaling, log sorting, careful log inspection, remanufacturing into ideal lengths, rescaling, moving logs to the deck, moving logs from decks to the dock, and loading the logs onto the ship.

The values previously shown for domestic manufacturing are the delivered log values. There is approximately $\$ 65$ per MBF of value added to the logs in domestic manufacturing. This includes offsetting costs of log scaling, log yard operations, milling and planing, and loading for shipping. Once the lumber leaves the mill yard, and before it reaches the end consumer, value continues to be added by the trucking or rail companies, wholesale yards, retail yards, and the builder.

\section{Specialty Products}

There continues to be a strong market for Port-Orford-cedar specialty products. These products, including arrow shafts, arrow shaft bolts, and boughs, generate at least $\$ 1.5$ million of value in the Port-Orford-cedar region each year. Demand exists to potentially double this value if a sufficient supply of raw materials were available. Most noteworthy of these products are arrow shafts and boughs.

\section{Arrow Shafts}

The unique strength, bending, and grain characteristics of Port-Orford-cedar have created a worldwide demand for Port-Orford-cedar arrow shafts. In the past, arrow shafts have been made by up to eleven manufacturers. Today only one arrow shaft manufacturer remains: Rose City Archery, Inc., of Myrtle Point, Oregon. Rose City Archery employs approximately 15 people year around with plans to add additional people in the near future.

Rose City Archery sells arrow shafts worldwide. The manufacturing process is labor intensive. Each arrow shaft is graded 14 times before it is completely through the process, and each shaft is individually tested for bending strength (fig. 7.8). A potential arrow shaft is first sawn into a square blank, then graded, sorted and dried. Once the square blanks are dry, each blank is shaped into an arrow shaft. These shafts are again graded and sorted. They are individually tested for bending strength, and sorted and graded again. With the by-products, Rose City Archery manufactures more than 100,000 garden stakes each year, as well as planter baskets and window boxes. Oil is distilled out of the sawdust and used for perfume, pet care products, aromatherapy, and mosquito repellant.

Port-Orford-cedar for arrow shafts is purchased by the cord (fig. 7.9), and between 250 and 300 cords are used each year. This wood comes from dead and down old-growth logs. In many cases these trees have been lying on the forest floor for many years. The present supply of old-growth Port-Orford-cedar needed for arrow shafts limits annual production to about 2.5 million. The demand exists to double the current production if additional old-growth logs were available. ${ }^{17}$ The value of arrow shafts and the byproducts have increased in each of the last five years.

${ }^{17}$ Dishion, Jerry. 1998. Personal communication. Owner. Rose City Archery, Inc, 94931 Quiet Valley Lane, P.O. Box 5, Myrtle Point, OR 97458. 


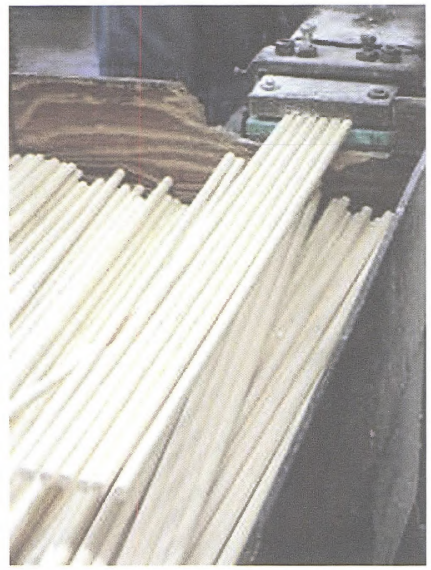

Figure 7.8-Arrow shafts awaiting grading and sorting

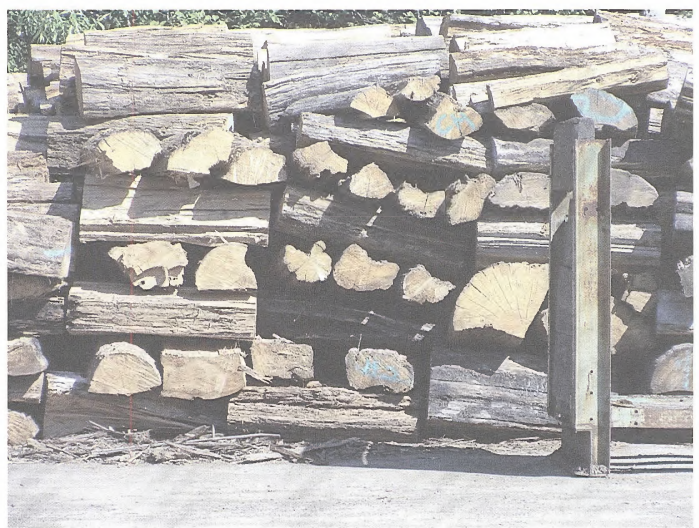

Figure 7.9-Bolts of Port-Orford-cedar to be used for producing arrow shafts 


\section{Boughs}

Port-Orford-cedar boughs are popular for use by the floral industry. A glycerin compound is drawn through the plant's vascular system, effectively preserving the boughs. Different colors of dye are added to the glycerin to color the boughs. PortOrford-cedar is better adapted to this preserving and drying process than other species such as western red cedar or incense cedar. Collecting boughs and manufacturing products occurs throughout the year. Ten businesses were identified which purchase boughs. Some were small family businesses that operate during the summer and fall, bundling and packaging fresh boughs that are sold to wholesale florists. Individual company's annual Port-Orford-cedar purchases range from a few thousand to a million pounds. ${ }^{18}$

Harvesters purchase bough permits for approximately $\$ .02$ to $\$ .05$ per pound. The harvesters collect boughs, cut them to length, bundle, and deliver them to brush houses or post-harvest processors who pay $\$ .25$ to $\$ .30$ per pound. Brush houses accumulate large quantities of boughs and sell them throughout the United States to wholesale and retail floral outlets. It is estimated 1.2 million pounds of Port-Orford-cedar boughs are purchased annually, with a value of approximately $\$ 330,000$ paid to the harvesters. The brush houses typically sell their products for about three times the value paid to harvesters. ${ }^{19}$

Value is added by arranging boughs into fresh wreaths, garlands, and greens during the holiday season, and by preserving and coloring the boughs for use throughout the year as wreaths, garlands, and arrangement foliage. Fresh and treated boughs are trimmed to the specification of the product being constructed. Half the purchase weight will often be trimmed in this process. Products manufactured by this process, such as garlands and wreaths, will wholesale at about ten times the purchase value. The retail price will often be double the wholesale price. The total value added to the boughs when they are retailed is about 20 times the price paid to the pickers. ${ }^{20}$ It is estimated boughs generate over $\$ 1$ million in value annually to the local economy. The demand for boughs has substantially exceeded the supply in recent years. The Forest Service and BLM have greatly restricted the sale of boughs because of concerns of spreading the pathogen, Phytophthora lateralis. Supply is unlikely to increase in the near future with the uncertainty of supply from federal lands. There is, however, a developing private boughproducing business (fig. 7.10) that has the potential to fill this demand.

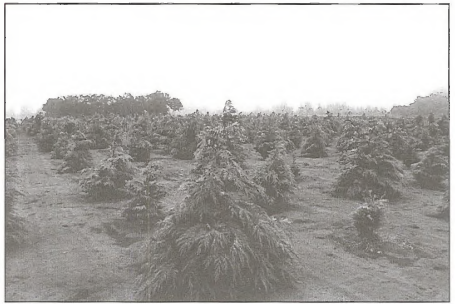

Figure 7.10-Port-Orford-cedar being cultivated for bough production

\footnotetext{
${ }^{18}$ Stevens, Mark. 1998. Personal communication. Hiawatha, Inc., 14301 Highway 42, Myrtle Point, OR 97458.

${ }^{19}$ 1999. Personal communication. Continental Floral Greens, 999 N. Front St, Coos Bay, OR 97420.
} 


\section{Employment}

Domestic manufacturing and exporting of Port-Orford-cedar generates jobs to support the local and regional economies. Domestic manufacturing of any timber, from stump to finished product, is estimated to generate 9.07 direct jobs per million board feet in southwestern Oregon (USDA and USDI 1994). Jobs included are logging, saw milling, mill working, and processing other wood products (chips and sawdust). An additional 8.75 indirect and induced jobs are created for every million board feet processed (FEMAT 1993).

Exporting of Port-Orford-cedar generates a similar amount of direct employment, only in different sectors of the job market. Such jobs include logging, scaling, inspecting and re-manufacturing, sorting, yard handling, stevedoring, and ship moving (tugs). In many cases, the logging of high value export Port-Orford-cedar is labor intensive, especially in cases where only the high quality trees are removed from a stand. When this is the case, the U.S. Department of Agriculture employment projections may underestimate the actual employment numbers.

Figure 7.11 shows the impact of changes in domestic manufacturing and exporting on employment over time. ${ }^{21}$ In 1990, the direct employment related to Port-Orford-cedar (excluding boughs) was estimated to be 138 jobs. The number of indirect jobs was estimated at 117, for a total of 255. A low was reached in 1995, with a total of 126 jobs, and rebounded to 166 jobs in 1997 . This trend tracks the total volume of Port-Orfordcedar harvest during the period. No data were available for employment from bough harvesting and processing, although over a million pounds are harvested annually, and this requires a great deal of labor.

It is estimated that, in 1997, 166 jobs in northwestern California and southwestern Oregon were related to Port-Orford-cedar. The counties most affected by employment related to Port-Orford-cedar harvesting in Oregon are Douglas, Coos, Curry, and Josephine. Unemployment rates in those counties, in 1997 for example, were more than double the average for the United States as a whole, making jobs particularly valuable. The counties most affected by employment related to Port-Orford-cedar harvesting in California are Del Norte and Humboldt counties.

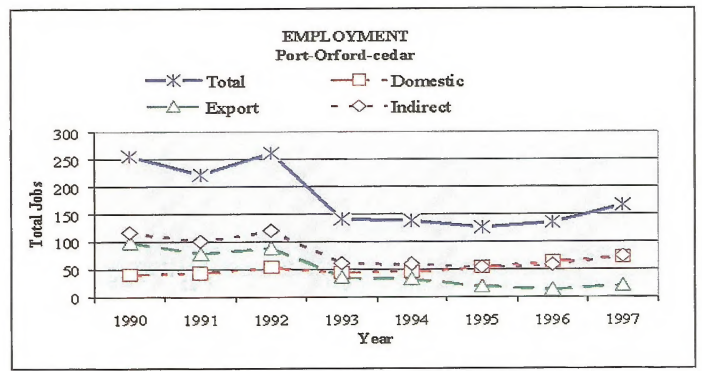

Figure 7.11-Number of jobs associated with Port-Orford-cedar 1990-1997

\footnotetext{
${ }^{21}$ Direct jobs were estimated using domestic and export volumes expanded by 9,07 jobs per million board feet. Seventeen jobs were added to account for arrow shaft production. Indirect jobs were estimated by expanding the volume by 8.75 jobs per million board feet.
} 


\section{County and State Revenues}

Prior to 1994, county receipts from the federal government paid to counties in-lieu-of taxes were based on the revenues generated by federal timber sales within each county. This was calculated as 50 percent of BLM and 25 percent of Forest Service revenues. When a high value species, such as old-growth Port-Orford-cedar was exported, the increased value provided a boost to local county receipts.

Court injunctions greatly curtailed the federal timber sale program beginning in 1991 . Timber volume harvested under contract with the federal government declined for the next several years as long-term contracts were completed. The NFP in 1994 called for an 80 percent permanent reduction from the level of federal timber harvest achieved during the 1980 s. The timber volumes allowed under the NFP were just beginning to be realized by 1998 , when court injunctions once again put a virtual halt to federal timber sales. Congress instituted a series of laws referred to as "safety net payments" to alleviate the impact of reduced income to the counties. ${ }^{22}$ These payments provided a percentage of the average receipts received during 1986 through 1990. A declining scale of payments was provided for the period 1995 through 2002 which calculated payments using average receipts from 1986 through 1990. Counties received 82 percent of the average in 1995 and were to receive 61 percent in 2002 , the final year the payments were to be in effect. ${ }^{23}$

In Oregon, timber taxes are required to be paid when timber is harvested. Private timber owners paid \$119,791 for Port-Orford-cedar harvest in 1997 (Western Oregon Privilege Tax). The Western Oregon Harvest Tax paid by all landowners for Port-Orford-cedar, in that same year, was $\$ 12,460$. The total tax paid for Port-Orford-cedar harvest was $\$ 132,252$ (table 7.2).

In California, a tax is levied on timber removed from all lands, except Indian Reservations. In 1997, the total yield tax paid for Port-Orford-cedar was $\$ 32,525$ (table 7.2).

The annual regional economic contribution of Port-Orford-cedar in 1997 is shown in table 7.3.

Table 7.2-Summary of Port-Orford-cedar timber taxes (1997 tax year)

\begin{tabular}{|c|c|c|}
\hline $\begin{array}{l}\text { California: } \\
\text { California Yield Tax }\end{array}$ & \multicolumn{2}{|c|}{$\$ 1,121,565$ stumpage value $* .029=\$ 32,525$} \\
\hline $\begin{array}{l}\text { Oregon: } \\
\text { Oregon Privilege Tax } \\
\text { Industrial Land Owners }\end{array}$ & \multicolumn{2}{|c|}{$\$ 3,743,488$ stumpage value $* .032=\$ 119,792$} \\
\hline Oregon Harvest Tax (Private lands) & $4,035 \mathrm{MBF} * \$ 2.11$ & $=\$ \quad 8,514$ \\
\hline Oregon Harvest Tax (Public lands) & $1,870 \mathrm{MBF}^{*} \$ 2.11$ & $=\$ \quad 3,946$ \\
\hline Subtotal Oregon Tax & & $\$ 132,252$ \\
\hline Total California and Oregon Tax & & $\$ 164,777$ \\
\hline
\end{tabular}


Table 7.3-Annual regional economic contribution of Port-Orford-cedar (1997 tax year)

\begin{tabular}{lc}
\hline Value of logs exported & $\$ 6,501,005$ \\
Value added - export $\left(2,208 \mathrm{MBF}^{*} \$ 100\right)$ & $\$ 220,800$ \\
Value of domestic logs & $\$ 5,166,477$ \\
Value added - domestic $\left(6,153 \mathrm{MBF}^{*} \$ 65\right)$ & $\$ 399,945$ \\
Specialty products & $\$ 1,500,000$ \\
State timber taxes & $\$ 164,777$
\end{tabular}

Total Direct Economic Value

$\$ 13,953,004$

\section{Literature Cited}

Brattain, D.; Stuntzer, R.E. 1994. Port-Orford-cedar alliance: response to ONRC's [Oregon Natural Resources Council's] proposal to list Port-Orford-cedar. Smith River, CA: 143 p. On file with: Southwest Oregon Forest Insect and Disease Service Center, J. Herbert Stone Nursery, 2606, Old Stage Road, Central Point, OR 97502.

Forest Ecosystem Management Assessment Team [FEMAT]. 1993. Forest ecosystem management: an ecological, economic, and social assessment. Portland, OR: U.S. Department of Agriculture; U.S. Department of the Interior [and others]. P. VI-34.

Stuntzer, R.E. 1991. Port-Orford-cedar Study: a report on the socio-economic impacts of the harvest of Port-Orford-cedar. Coos Bay, OR. 56 p. On file with: Southwest Oregon Forest Insect and Disease Service Center, J. Herbert Stone Nursery, 2606, Old Stage Road, Central Point, OR 97502.

U.S. Department of Agriculture, Forest Service. 1973. Port-Orford-cedar, an American wood. FS-228. Washington, D.C. 7 p. On file with: Southwest Oregon Forest Insect and Disease Service Center, J. Herbert Stone Nursery, 2606, Old Stage Road, Central Point, OR 97502.

U.S. Department of Agriculture, Forest Service; U.S. Department of Interior, Bureau of Land Management. 1994. Final supplemental environmental impact statement on management of habitat for late-successional and old-growth related species within the range of the northern spotted owl. Portland, OR. 322 p.

Warren, D.D. 1985. Production, prices, employment, and trade in northwest forest industries. Portland, OR: U.S. Department of Agriculture, Forest Service, Pacific Northwest Research Station.

Warren, D.D. 1998. Production, prices, employment, and trade in northwest forest industries, third quarter 1997. PNW-RB-229. Portland, OR: U.S. Department of Agriculture, Forest Service, Pacific Northwest Research Station: 30, 33, 35.

Zobel, D.B. 1986. Port-Orford-cedar: a forgotten species. Journal of Forest History. 30: 29-36.

Zobel, D.B.; Roth, L.F.; Hawk, G.M. 1985. Ecology, pathology, and management of PortOrford-cedar (Chamaecyparis lawsoniana). General Technical Report PNW-184. Portland, OR: U.S. Department of Agriculture, Forest Service Pacific Northwest Forest and Range Experiment Station. $161 \mathrm{p}$. 


\section{Chapter 8 Social Value of Port-Orford-Cedar}

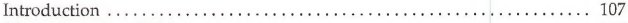

Native American Values ................................... 107

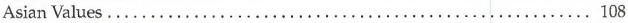

Local Values, Case Study 1: The Williams Port-Orford-Cedar Management Project 109

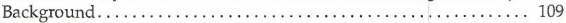

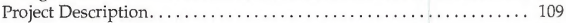

Late-Successional and Riparian Reserve Management .......... 109

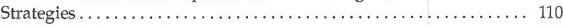

Treatments..................................... 110

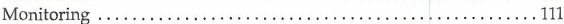

Reactions of Williams Residents . . . . . . . . . . . . . . . . 111

Landscape Approach to Managing Port-Orford-Cedar.......... 114

Local Values, Case Study 2: Managing Port-Orford-Cedar in High Plateau . . 114

Public Values and User Conflicts. . . . . . . . . . . . . . . 115

Disease Management in the Smith River Basin and High Plateau. . . . 116

The Controversy Heats Up: The Six Rivers Forest Plan ......... 116

Taking a Strategic Approach. ......................... 118

Special Interest Area (SIA) Management Strategy ............. 119

Assessing the Level of Risk to Port-Orford-Cedar in High Plateau . . . 120

Why Propose A Year-Round Closure? .................... 120

The Public Response . . . . . . . . . . . . . . . . . . . . . . 121

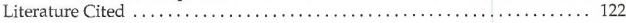

Authors: Frank Betlejewski, Laura M. Chapman and Kathy McClellan-Heffner

June 2001 
A Range-Wide Assessment of Port-Orford-Cedar on Federal Lands 


\section{Introduction}

Port-Orford-cedar has had a long history of use by humans. In addition, sectors of society have become increasingly knowledgeable about the importance of Port-Orfordcedar's ecological roles, concerned about the affects of Phytophthora lateralis on the species and the ecosystem, and involved in efforts to maintain Port-Orford-cedar within its natural range. In recent years, public input has been significant in shaping federal agencies' Port-Orford-cedar root disease management approaches (see Appendix G for a summary of the development of the interagency Port-Orford-cedar coordination effort).

This chapter on social values does not attempt to provide a definitive discussion of the wide array of human values associated with Port-Orford-cedar. Rather, it highlights a few examples that illustrate the range of social concerns with the species, changes in social perceptions and objectives since the Zobel et al. monograph was written in 1985, and the challenges that managers face in trying to address often widely diverging concerns from the public and interest groups. Specifically, it focuses on Native American people's use of Port-Orford-cedar, Japanese use and changing values, and two case histories which portray the types of public concerns that surface with regard to management of Port-Orford-cedar root disease in southwestern Oregon and northwestern California.

\section{Native American Values}

Aboriginal use of Port-Orford-cedar began in antiquity (Beckham 1971). Several southwestern Oregon Bands and Tribes lived within cedar forests that influenced their daily lives. Other tribes in northern California made use of Port-Orford-cedar that occurred within forests dominated by Douglas-fir and redwood, and considered PortOrford-cedar to be an integral part of their way of life. Today, Port-Orford-cedar plays a significant role in the cultural, medicinal, and religious life of many Tribes. Tribes that use Port-Orford-cedar include the Confederated Tribes of Grande Ronde, the Confederated Tribes of Siletz, the Confederated Tribes of Coos, Lower Umpqua, and Siuslaw, the Cow Creek Umpqua Indians in southwestern Oregon, the Coos-Coquille Tribe around Coos Bay, and the Hoopa, Upper Tolowa, Yurok, and Karuk Tribes in northern California (Beckham 1971, Heffner 1984, Hendryx and Hendryx 1991, Miller and Kenetta 1996).

Known for its durability, Port-Orford-cedar was, and still is, used to construct living and sweat houses, both of which hold ceremonial functions. Historically, wind thrown cedars or drift logs were preferentially used, before resorting to live felling. While the cedar living house is no longer used as a permanent residence, it is still constructed for ceremonial purposes. The sweathouse continues to be actively used by individuals, families, and communities (Jimerson 1994).

Native Americans use many parts of the Port-Orford-cedar tree. Buds are used to heal sore lungs, throats, and toothaches. Coughs can be treated with the leaves. The bark and twigs are used to heal kidney problems. Regalia items used in religious ceremonies can also be made from the wood. Other items, such as feathers and hides, are stored in PortOrford-cedar trunks because the oils and aroma of the wood repel insects (Heffner 1984).

While some tribes own lands with Port-Orford-cedar, some do not. Tribes that do manage Port-Orford-cedar on their reservation lands include the Hoopa and Yurok Tribes in northern California. The Hoopa's land management reflects and emphasizes the cultural and religious value of Port-Orford-cedar and the Tribe's concern about the impacts of the root disease caused by P. lateralis. In 1986, Tribal Resolution established a policy that prohibited the cutting of Port-Orford-cedar, except for ceremonial and 
religious uses. The Tribe's land management plan initiated the establishment of reserves, encouraged continual planting of the species, and closed all dead-end roads in the portion of the range of Port-Orford-cedar on the reservation (Hoopa Tribal Forestry 1994, Pacific Meridian Resources 1996). The Karuk Tribe also has established an ancestral lands forest management plan that reflects its desire to protect Port-Orford-cedar from the root disease (Karuk Tribe of California 1989).

In 1996, President Clinton signed into law legislation that created the Coquille Tribal Forest from lands formally managed by the Coos Bay District Bureau of Land Management (BLM). Two years later, 5,400 acres were transferred from the BLM to the Bureau of Indian Affairs to be managed in trust for the Coquille Indian Tribe. This land has a small amount of Port-Orford-cedar, which is to be managed based upon the guidelines in use by the BLM at the time the land was transferred (USDI 1995a).

Tribes that do not have Port-Orford-cedar as part of their reservation landscape depend on federal lands to obtain the much-needed wood as they build cultural structures for ceremonial use. Providing access to, and harvest of, Port-Orford-cedar by tribal governments and traditional practitioners raises many issues. Conflicts have arisen between desires of federal managers to protect healthy stands of Port-Orford-cedar from P. lateralis and desires of Native American groups to be granted access to culturally significant locations. Providing access for ceremonial use of the wood has also caused controversy. Many Tribes have requested free use of Port-Orford-cedar for ceremonial purposes.

\section{Asian Values}

Old-growth Port-Orford-cedar wood has characteristics very similar to hinoki and other Asian Chamaecyparis species, and has been highly valued since the mid-1800s by Asian societies, especially the Japanese. The wood has religious and ceremonial significance and has been used to replace wood in temples, posts and beams in tatami rooms, sushi bar counter tops, and lintel pieces in homes.

Historically, the Japanese have found the light-colored, fine-grained wood of Port-Orfordcedar trees 200 years old or older to be especially desirable for their uses. They have been willing to pay extremely high prices, among the highest ever paid for any conifer, for quality cedar logs from California and Oregon (see Economics chapter, Chapter 7). Because of Japanese demand, export values for Port-Orford-cedar have in the past been so much higher than domestic values that Port-Orford-cedar logs have been exempt from federal unprocessed log export bans.

In recent years, Japanese interest in Port-Orford-cedar has declined. The economic problems suffered in Japan have undoubtedly contributed to this, but cultural changes are also responsible. The current generation of Japanese is less influenced by traditional values and is simply less willing to pay the high prices that Port-Orford-cedar commanded in the past. 


\section{Local Values, Case Study 1: The Williams Port-Orford-Cedar Management Project}

\section{Background}

The Williams Creek Watershed contains Port-Orford-cedar at the easternmost extent of its range within southwestern Oregon. It has both healthy stand components and stand components infested with the pathogen P. lateralis. The Medford District BLM, Grants Pass Resource Area proposed the Williams Port-Orford-Cedar Management Project to reduce $P$. lateralis in those areas where it currently exists and to prevent export of the pathogen to uninfected stands. The project was intended to operationally evaluate the current best-known approaches for controlling $P$. lateralis at a small scale. The scenario was to implement a multi-faceted, integrated strategy to determine biologically effective and economically feasible techniques for control of the pathogen.

\section{Project Description}

The Williams Creek Watershed is located approximately 12 miles southwest of the community of Grants Pass and 20 miles west of the city of Medford in the southwest corner of Josephine County, Oregon. There are approximately 52,000 acres in the watershed. Of these, the BLM administers 26,990 acres ( 52 percent), the Forest Service administers 819 acres ( 1.5 percent), Josephine County owns approximately 1,670 acres (3.2 percent), and commercial timber companies and individuals own the remaining 43 percent (USDI 1996b).

The 1995 Medford District Resource Management Plan (USDI 1995b) and the Northwest Forest Plan (USDA and USDI 1994b) provide overall direction for managing lands administered by the BLM in the Williams Creek Watershed. The Williams Creek PortOrford-Cedar Management Project incorporates the recommendations of the BLM PortOrford-Cedar Management Guidelines (Betlejewski 1994), which were adopted in the 1995 Medford District Resource Management Plan (USDI 1995b).

The project design draws upon many documents which provide guidelines for management: the Southwest Oregon Late-Successional Reserve Assessment (USDA and USDI 1995b), the Applegate Adaptive Management Area Ecosystem Health Assessment (USDA and USDI 1994a), the Applegate River Watershed Assessment: Aquatic, Wildlife, and Special Plant Habitat (USDA and USDI 1995a), the Western Oregon Transportation Management Plan (USDI 1996a), and the Williams Watershed Analysis (USDI 1996b).

\section{Late-Successional and Riparian Reserve Management}

Almost the entire project is within Late-Successional or Riparian Reserve land allocations and most of the late-successional forest in the watershed is on BLM-administered lands. While the project is within Late-Successional and Riparian Reserves, the over-riding land use allocation is Adaptive Management Area (AMA). The project lies within the Applegate AMA. Objectives of this AMA are to develop and test variations of established management practices that provide late-successional forest and high-quality riparian habitat (USDA and USDI 1994a).

The primary project objective is to prevent late-successional forests containing PortOrford-cedar from becoming infested. Other objectives are retention of large (greater than 21 inches DBH) live Port-Orford-cedar for species and structural diversity, retention of old-growth snags as described by Jimerson (1989), and accelerated late-successional 
habitat development where it currently does not exist in Late-Successional and Riparian Reserves. The long-term objective is reintroduction of disease resistant Port-Orford-cedar to areas where the species has been killed by the pathogen.

Past timber harvest has reduced the number of large conifers available for dead wood recruitment to streams and Riparian Reserves (USDI 1998). The project seeks to retain a late-successional snag component (conifers) where it currently exists and accelerate the development of such a component where it is minimal or absent. With no management intervention, additional infection of live Port-Orford-cedar has the potential to increase levels of infestation as a result of increased pathogen population levels. Removal or mortality of Port-Orford-cedar in Riparian Reserves may affect fish habitat both beneficially (long-term snag and dead wood recruitment) and non-beneficially (loss of streamside shading and higher water temperatures). Thinning in Riparian Reserves would enhance tree growth resulting in large diameter trees and a future large wood component in the reserves. Creating snags would enhance the current large wood component.

\section{Strategies}

The project incorporates four strategies for controlling the spread of $P$. lateralis:

1. Create sites unfavorable to the pathogen by thinning stands to allow more light, and therefore heat, which penetrates to the forest floor and has been shown to be detrimental to $P$. lateralis (Ostrofsky et al. 1977).

2. Remove host species from areas key to the spread of the disease to prevent the pathogen from reproducing. Preliminary work by the Southwest Oregon Forest Insect and Disease Service Center indicates that sporeload, along infested roads, decreases 3 to 4 years after sanitation treatments that eliminate Port-Orford-cedar.

3. Manage stands to break up the continuity of live Port-Orford-cedar host trees to prevent root-to-root spread of the pathogen. This strategy would remove all PortOrford-cedar within a 2 crown-width radius of an infected tree in infested areas; within uninfested areas, Port-Orford-cedar free zones of about 4 crown-width radii would be established (Daniel et al. 1979, Gordon 1974, Gordon and Roth 1976).

4. Manage roads and public access to prevent further spread of the pathogen. Motor vehicles can contribute substantially to the spread of the pathogen. However, mountain bikes, livestock, and even foot travel can also disperse the pathogen across the landscape (Betlejewski 1994).

\section{Treatments}

The Williams Port-Orford-Cedar Management Project designed the following treatments to meet the objectives of the strategies outlined above:

Port-Orford-Cedar Exclusion Treatments (Sanitation) in Infested Areas-A prescription was established to provide criteria for Port-Orford-cedar tree removal below a road considering site-specific information, including individual tree height and distance from the road. Other factors considered for sanitation treatments were human safety concerns for falling snags on the roadway, potential Port-Orford-cedar theft, and the associated risk of spreading the pathogen.

Roadside Treatments for Roads Open in Uninfested Areas-Within a maximum distance of 25 feet upslope and 50 feet downslope of the road, as measured from the toe of the fill, all Port-Orford-cedar trees would be removed. Commercial trees would be harvested 
and noncommercial trees would be cut, hand-piled and burned. The remaining trees and shrubs would be thinned and the slash would be piled and burned. Bough cutting would only be allowed during the dry season and would occur in uninfested roadside treatment areas first, then infested roadside treatment areas.

Commercial Thinning Treatments in Uninfested Areas - Commercial thinning prescriptions were designed to reduce overall tree density, accelerate the development of larger diameter trees (both conifers and hardwoods), and increase the conifer component of the stands. In these areas, Port-Orford-cedar was favored for retention.

Pre-commercial Thinning Treatments-These treatments were proposed to accelerate the development from early seral shrub stage to a closed-canopy conifer and hardwood forest. In stands infested with $P$, lateralis, Port-Orford-cedar would be selected for removal. In pathogen-free stands, Port-Orford-cedar would be retained, with the exception of areas designed to break up continuous distribution across the landscape.

Road Decommissioning, Closures, and Maintenance-Decommissioning of 0.21 miles of road and the gating of 18 miles of road would close a 4 to 5 square mile un-infested area. Subsequent road maintenance and repair would improve road drainage and reduce sediment flow (USDI, 1998).

Vehicle Washing-Vehicle washing stations would be constructed. All vehicles associated with a timber sale would be washed prior to leaving an infested area and prior to entering an uninfested area. To lower any additional risk, uninfested areas would be entered first, followed by infested areas. Washing would not be required for site-preparation, slashing crews, or bough collectors; however, parking areas, access, and egress routes were identified and work would be permitted only during the dry season.

\section{Monitoring}

Effectiveness monitoring was developed as part of the project and builds upon previous work completed by the Southwest Oregon Forest Insect and Disease Service Center. Project implementation and monitoring will determine the effectiveness of this project for meeting long-term objectives.

Local residents were employed to conduct part of the monitoring. This helped create a feeling of local ownership in the project and also built stronger trust between the residents and the BLM.

\section{Reactions of Williams Residents}

Information concerning Port-Orford-cedar management and P. lateralis control strategies was provided to the community from 1996 through 1998. This outreach consisted of presentations to the Applegate Partnership and the Williams Town Council, and two public field trips to review portions of the project area (fig. 8.1). 


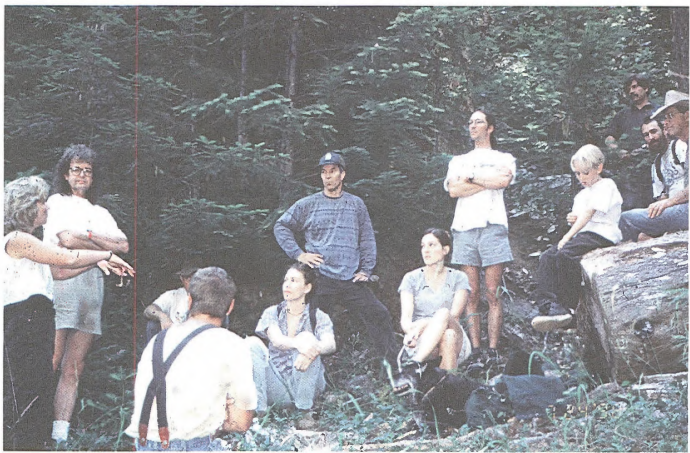

Figure 8.1-Teresa Gallager-Hill, BLM Realty Specialist, discussing reciprocal right-ofway and road use agreements on a public tour near Williams, Oregon

The Williams Neighborhood (described in Words into Action: A Community Assessment of the Applegate Valley (Preister 1994)) is recognized as "an independent-minded community .... represented by resource workers, alternative community, farmers, retirees, commuters, trade and service workers, and many entrepreneurs. Community issues include school funding, forest management, and land use" (Preister 1994). Attitudes from the community concerning BLM activities in the Williams Neighborhood generally range from positive or neutral to those that believe human management has resulted in degradation to the environment" (Preister 1997).

Public and community concerns in response to the Williams Port-Orford-Cedar Management Project were compiled from letters, faxes, newspaper articles, and phone conversation records occurring between September 12, 1996, and December 17, 1998. The local watershed council, town council, environmental groups, the timber industry, the Applegate Partnership, and private individuals expressed the following ideas and concerns:

- Project actions or unproven management methods should not take place in Riparian and/or Late-Successional Reserves or unentered forests. Too little late-successional forest remains and old-growth forests are being converted into tree plantations.

- More scientific research and peer review is needed before planning a project of this nature. Some critics stated that the project should be on a much smaller scale, while others thought the project was not large enough to be effective in stopping the spread of the pathogen. Many citizens wanted more scientific evidence supporting the effectiveness of the management techniques before moving forward.

- Bough collecting or logging activities within the project may inadvertently further spread the disease. 
- There was general agreement that some management should be attempted, however, there was disagreement as to what types of management should occur. Some people responded with suggestions for what they believed to be less invasive treatments, such as fertilizing soils (suggesting that healthy soils would stop the spread of the pathogen). Other ideas included planting horsetails (Equisetum) or other species believed to have anti-fungal properties, focusing priorities on uninfested areas rather than infested areas, and planting Port-Orford-cedar in areas unfavorable to the pathogen.

- Some felt that county, state, and federal agencies need to take more responsibility for management of Port-Orford-cedar and control of $P$. lateralis, with plans encompassing entire watersheds. Mapping of watersheds should be done and treatments should be the same, regardless of ownership. Land exchanges should be considered, blocking up ownership would allow more consistent management.

- A lack of trust was expressed concerning the use of timber harvest to control the spread of the disease. It was felt that this type of management was an excuse to harvest timber and reflected commodity extraction as a priority over the environment. Statements such as, "the proposal calls for killing the cedar in order to save them," reflected this distrust.

- Some believed the appropriate consultation and review had not occurred, and that the BLM was not following its own management strategies (i.e., Northwest Forest Plan and watershed analysis recommendations).

- Some felt that more restrictive road management should occur across all ownerships, including road decommissioning (with culvert and ditch line removal), gating, installation of more wash stations, and seasonal road closures during the wet season.

- Many watershed residents wanted greater participation in management of their watershed and wanted more efforts to communicate with the public. Earlier notification of meetings, more field trips and presentations to the community, and public education pamphlets were examples of better communication.

- Participants felt the field trips were informative. Some supported the project, stating it was good and should be attempted as long as the watershed was not degraded, local workers were employed, and it contributed to the local economy.

Many diverse opinions on how to address the management of Port-Orford-cedar and control $P$. lateralis surfaced during this public comment period. While all comments were considered and addressed, not all comments resulted in changes to the project. For example, the comment/ proposal to fertilize soils to make them less susceptible to disease was not incorporated. An infested part of the project area had previously been fertilized and observations did not show less susceptibility of Port-Orford-cedar to P. lateralis.

The project went through extensive peer review during the two-year development period, with reviewers representing the U.S. Fish and Wildlife Service, the Regional Ecosystem Office, Forest Pest Management Northern California Service Center, and the Southwest Oregon Forest Insect and Disease Service Center. 


\section{Landscape Approach to Managing Port-Orford-Cedar}

The project focuses on lands administered by the BLM. While complementary approaches to Port-Orford-cedar management on private and public lands are desirable, the extent of potential cooperation is difficult to estimate. At least one citizen's opinion was "that if the management techniques proposed as part of this project proved effective, private landowners would likely continue the management practices onto their own lands." 24

Others have recognized the need of complementary management that crossed property boundaries. This model of collaboration between citizens, scientists, and managers was recognized by the Forest Ecosystem Management Assessment Team and was deemed important and to be used in conjunction with the concept of Adaptive Management Areas. New working relationships were envisioned which could be developed across land ownership patterns, jurisdictional arrangements, and social environments (Shannon and Sturtevant 1995). There were at least two opinions on how this could be accomplished. In some cases, support was given for the BLM proposal to be a test case. The project could be implemented, and if proven successful, it could then be incorporated on other ownerships. Others thought that the project would not work unless private owners participated from the beginning.

\section{Local Values, Case Study 2: Managing Port-Orford-Cedar in High Plateau}

Since Port-Orford-cedar root disease ( $P$. lateralis) was first identified in the Smith River basin in 1980, there has been growing public interest in the actions that the Six Rivers National Forest is taking to minimize the risk of spreading the disease. The Forest has undertaken several strategies to control spread, including washing of vehicles, limiting construction and timber harvest activities to the dry season, and altering the design of roads and timber sale operations. One of the most effective control measures is also the most controversial - the gating of roads to prevent vehicles from picking up infested soil and transporting it to uninfested areas. The gating of roads in the High Plateau area within the North Fork Smith River watershed is very controversial. Management of the High Plateau has been the source of conflict among user groups with vastly different interests and core values, and the Forest's efforts to protect Port-Orford-cedar in the area illustrates the difficulties that land management agencies face in trying to resolve these differences. Although this case study focuses solely on the High Plateau area, the issues raised by the public exemplify the concerns expressed regarding Port-Orford-cedar root disease management across the Forest.

High Plateau hardly seems to be the kind of place that would spark much controversy. It is remote; a long drive from any populated area, requiring travel along infrequently maintained and rugged dirt roads. The infertile serpentine soils in the area support only sparse vegetation, giving the area an open, dry, sun-baked character. The area is full of historic mines; mining roads, tailing piles, and old mining equipment litter the area. Yet it is precisely the remote and rugged character of the area that appeals to several distinct and divergent groups.

\footnotetext{
${ }^{24}$ Hill, D.S. on behalf of the Southern Oregon Timber Industries Association. 1998. Letter to the Grants Pass Resource Area Field Manager supporting the Record of Decision for the Williams Port-Orford-cedar Management Project. On file with: U.S. Department of the Interior, Bureau of Land Management, Medford District, Medford, OR.
} 


\section{Public Values and User Conflicts}

Botanical and environmental groups value High Plateau for its biological diversity. High Plateau is located within the North Fork of the Smith River. It is part of the Josephine ultramafic sheet (a mineral-rich rock formation), one of the most extensive ultramafic landscapes in North America. Because serpentine soils derived from this ultramafic parent material are infertile, the area is not conducive for growth of most plants, and vegetation is sparse and scrubby. However, a variety of unique plant communities have adapted to tolerate these harsh soil conditions. As a result, the High Plateau is one of the most botanically significant areas on the Forest. Many rare and endemic plant species are found within its plant communities, including one federal and state listed endangered species and nine Forest Service sensitive species.

Port-Orford-cedar is found throughout the North Fork Smith River watershed in association with many of the plant communities and is valued as a member of the forest ecosystem. Particular concern, however, is given to the High Plateau because of its link with unique plant communities. Public interest in this area, coupled with the Forest's recognition of its unique character, led to the establishment of the 21,370-acre North Fork Smith Botanical Area, which is centered around the High Plateau.

Few people travel to High Plateau each year. The Forest estimates that less than 100 vehicles travel the main access roads into the High Plateau--roads 18N09, 18N13, and their associated spur roads--annually, mostly during the summer months. A few people visit the area for botanical and scenic sightseeing, hunting, mineral collecting, and traditional Native American use; but by far the primary use of the area is by off-highway vehicle (OHV) enthusiasts (four wheel drive vehicles, all-terrain vehicles, and dirt bikes).

Although they are small in number, the people who recreate in High Plateau are a vocal group with strong ties to the area. Some of them have been visiting the area for over 30 years, valuing the solitude and challenge that High Plateau offers. OHV enthusiasts like High Plateau for two reasons. First, the area is remote and the roads are rugged and difficult to traverse. High Plateau is crisscrossed with old mining roads; many of them were not built to Forest Service standards. Without adequate drainage, numerous ruts and gullies have been formed by water flowing across the roads. There are also some challenging low water crossings that are impassable during high flows. Second, the route created by the roads $18 \mathrm{~N} 09$ and $18 \mathrm{~N} 13$ is the only loop route on the Forest. Organized groups have made annual trips to the area.

Since the 1980s, these two distinct public interest groups, the environmental groups on the one hand and the OHV enthusiasts on the other, have been voicing their concerns about the Forest's management of High Plateau. Because the area is home to a variety of rare and unique plant communities, botanical and environmental groups have advocated restricting OHV use of the area. They believe that OHV use is not appropriate within a Botanical Area that, according to the Six Rivers Land and Resource Management Plan (USDA 1995), is to be managed to "maintain ecological processes and the unique values for which the area was designated." On the other hand, the OHV community notes that there are few areas in the vicinity which provide the same type of recreational opportunities. Many feel that environmental groups and some Forest Service staff do not like OHV recreation in general, and that the North Fork Smith Botanical Area was established simply to limit OHV use of the area. 


\section{Disease Management in the Smith River Basin and High Plateau}

Port-Orford-cedar root disease has spread to most of the drainages in the North Fork, Middle Fork, and Main Stem Smith River watersheds. However, the drainages in the High Plateau area (High Plateau, Bear, Stony and Peridotite Canyon Creeks) remain uninfested, forming the largest island of uninfested subwatersheds within the North Fork, Middle Fork, and Main Stem Smith River watersheds. These drainages also represent the largest uninfested island in the Josephine ultramafic sheet. There are a number of theories as to why this area is still uninfested.

One theory is that the low level of use has provided little opportunity for the disease to enter the area. During high flow periods the low water crossings are impassable, preventing travel to High Plateau during much of the wet season. Another untested theory is that infested soil, and thus the pathogen, may be washed from tires during the low water crossings before entering the high country. Some people believe that luck is the only reason why the disease has not yet infected these watersheds.

At the beginning of the debate regarding High Plateau, Forest direction for management of the area was considered by some to be vague and even confusing. According to the Smith River National Recreation Area (NRA) Act of 1990, the management emphasis for the North Fork of the Smith is on "back-country and whitewater recreation, while recognizing the unique botanical communities, outstanding whitewater, and historic and scenic values." The Act also requires the Forest to "provide for the long-term viability and presence of Port-Orford-cedar and ensure its continued present economic and noneconomic uses through implementation of management strategies developed by the Forest Service." The Smith River Management Plan direction for the North Fork Smith notes that, "the abundant access these [historic mining] roads provide, along with the unusually erosion resistant soils, provide an excellent opportunity for managed OHV use." In fact, the Plan highlighted roads 18 N09 and 18N13 as OHV routes.

As the controversy regarding management of High Plateau was brewing, the Forest was also becoming more proactive in preventing the spread of Port-Orford-cedar root disease within the Smith River Basin. Forest staff installed gates on many roads and closed them during the wet season to prevent the import or export of the disease. Seasonal gates were installed on both $18 \mathrm{~N} 09$ and $18 \mathrm{~N} 13$, but they were repeatedly damaged or destroyed by vandals.

\section{The Controversy Heats Up: The Six Rivers Forest Plan}

In 1994, Six Rivers National Forest released its draft Land and Resource Management Plan (Forest Plan) for public comment. The Forest received a number of comments about the management of Port-Orford-cedar in general, which are summarized below:

- The Forest must consider the role of Port-Orford-cedar in the maintenance of biological diversity, including its roles in riparian ecosystems, in sensitive plant habitat, and as an old-growth component of ecosystems.

- Current project-level efforts to prevent the spread of Port-Orford-cedar root disease are inadequate. The Forest needs to improve its strategy for preventing the spread of Port-Orford-cedar root disease by analyzing Port-Orford-cedar at a broader scale.

- The Forest should close/obliterate roads, prevent construction of new roads, and prohibit/limit access into watersheds containing uninfected Port-Orford-cedar to control the spread of Port-Orford-cedar root disease. 
- Do not log stands containing Port-Orford-cedar until studies are completed for the protection of existing healthy stands.

In addition to these general comments, some people commented specifically about PortOrford-cedar management and road access in the High Plateau area. Excerpts from their comments are provided below.

- Port-Orford-cedar is often the dominant or only riparian conifer found in the stream corridors within these watersheds. The cedars are also found in other wetlands. On these sites they often provide some of the only available shade. Wetlands and stream corridors, especially in ultramafic soils, harbor many rare and sensitive plant species. The cedar's calcium content also provides important ameliorative effects for other species and possible aquatic invertebrates. Loss of cedar due to root disease introduction will impact riparian ecosystems and sensitive plant habitat and also affect the outstanding values of National Wild and Scenic Rivers.

- The introduction of the root disease into uninfested watersheds is irreversible and causes long-term and continued ecological destruction. Roads and logging have spread the root disease into many of the major watersheds of the Smith River Basin. Subwatersheds (such as High Plateau Creek, Stony Creek, and Peridotite Canyon) may be some of the last best hopes for maintaining uninfected riparian and wetland cedar ecosystems in the Basin especially on ultramafic parent material.

- The High Plateau area contains some of the finest stands of uninfected Port-Orfordcedar remaining on the Smith River NRA, mostly associated with the many drainages flowing into the North Fork of the Smith River. Vehicles entering High Plateau must pass through areas infected with Port-Orford-cedar root disease; the OHV route on High Plateau advocated by the Forest actually passes through the headwaters of Stony Creek, known for its exceptional diversity in rare plants and unique plant communities. The impacts of partial or complete loss of Port-Orford-cedar in plant communities where it is a dominant are not known; such large-scale perturbations could negatively impact the many rare species that often occur with Port-Orford-cedar. Therefore, increased OHV use not only risks loss of the exceptional Port-Orford-cedar stands in this area, but may also impact associated rare species.

In 1995, in response to public comments, the Forest incorporated a number of standards and guidelines into the final Plan, including the following:

- Integrate strategies for reducing the risk of Port-Orford-cedar infection from the root disease into all levels of planning and analysis (e.g. watershed analysis, transportation and recreation planning, Late Successional Reserve Assessments, National Environmental Policy Act [NEPA] assessments) in watersheds where it is present.

- Undertake pro-active disease prevention measures such as road closures, road maintenance, and sanitation removal of roadside Port-Orford-cedar to prevent the spread of the disease, especially to high risk areas. Identify specific prevention measures at the drainage or project level.

In addition, because of the comments that were specifically focused on Port-Orford-cedar root disease and access within the North Fork Smith Botanical Area and High Plateau, a team of Forest specialists assessed the risk of introducing Port-Orford-cedar root disease into the North Fork Smith Botanical Area. The team developed a set of criteria, and used those criteria to assess five alternatives for access. The Forest Supervisor selected an alternative that had a low risk of introducing the disease into the area. The alternative 
included: year-round closure of road $18 \mathrm{~N} 09$, with dry season use allowed under a permit system; and permanent closure of road $18 \mathrm{~N} 13$ due to the poor road conditions (the road had a low water crossing and year-round wet spots from seeps and springs), and the proximity of Port-Orford-cedar to the road.

However, the Forest Supervisor and Forest planning staff were not aware that the Smith River NRA had signed an agreement with a local four-wheel drive group who adopted Road 18 N13 and wanted to maintain it. When the Final Plan was released, they appealed the Forest Plan decision on the basis that it was made without adequate public input. In addition to the closure of Road 18N13, the Forest Plan called for the decommissioning of 25 miles of road annually to benefit aquatic habitats. These measures incensed a number of local individuals and groups who recreate on the Forest and believe that the Forest Service should not close existing roads or access to public lands. They felt that roads were being closed not to protect forest resources, but because people do not like OHVs. They contacted other regional and national groups, and the Forest received numerous letters, plus another appeal from a national four wheel drive association. Their concerns are illustrated in the comments below:

- The North Fork Smith Botanical Area contains the only real OHV trail system on the Forest. It appears that the designation of this area is intended to stop OHV use, rather than to preserve plant species, because some user groups and individuals object to OHV use and / or believe some OHV users might act illegally.

- The Six Rivers is willing to create any reason to close roads. It is clear that the direction of the Forest Service is to close roads and therefore, close national lands to the public. If the risk of spread of the fungus into the High Plateau area is indeed great, as Forest staff insist, then use of this road (18N09) over the last 30 years would have already resulted in introduction of the disease.

- The basis of this appeal is the plan's reduction in mileage of open Forest Service roads to recreational four-wheel drive vehicles, while the demand is rapidly increasing for areas to drive. Cutting access to those areas simply deprives four-wheel drive owners and their families from experiencing some of the most scenic parts of the forest and increases impacts to other areas.

In October 1995, the Washington Office reversed the Regional Forester's Forest Plan decision based on the fact that the Forest Plan did not specify that it made any sitespecific decisions. The appeal decision also required the Forest to perform a site-specific environmental analysis under NEPA (the National Environmental Policy Act) to assess the risk posed to Port-Orford-cedar by road access in the area, and also specified that Road $18 \mathrm{~N} 13$ remain closed until the analysis was completed. In the meantime, heavy winter rains triggered a large landslide on Road 18N09, making the road impassable and eliminating the only remaining access to High Plateau.

\section{Taking a Strategic Approach}

By this time, the two sets of public interests were highly polarized, not just about High Plateau, but about road access and Port-Orford-cedar root disease prevention measures in general. The Forest did not think that immediately performing a site-specific environmental analysis for High Plateau would resolve these differences. Instead, the Forest decided to step back and take a more strategic approach to the interrelated issues of Port-Orford-cedar protection, road access, recreational use, and the management of Botanical and other Special Interest Areas. In February 1996, the Forest leadership team agreed to undertake the following efforts: 
Port-Orford-cedar Risk Assessments-The Smith, Klamath, and Trinity River basins were divided into sub-watersheds. Roads and management activities were evaluated in terms of the risk they posed to Port-Orford-cedar. The assessments identified risk levels for both roads and watersheds and proposed mitigation measures. They also prioritized watersheds for protection based on the amount of Port-Orford-cedar in the watershed, the level of risk, and the ability of the Forest to protect the watershed from infestation.

Port-Orford-cedar Plant Association Mapping-The Forest's ecology staff mapped PortOrford-cedar plant associations throughout northern California. This effort identified the extent and location of the different Port-Orford-cedar plant associations, and also refined information on the extent of the root disease. The mapping effort provided highly detailed information of Port-Orford-cedar that is useful at both landscape and project levels.

Port-Orford-cedar Public Education--The Forest developed posters, brochures, and other information to help get the word out about Port-Orford-cedar, what the Forest was doing to prevent the spread of the root disease, and what the public could do to help. Public affairs officers worked with the newspaper, radio, and local TV on articles, news briefs and interviews about Port-Orford-cedar and the root disease. Forest staff made presentations to schools and special interest groups.

Consistent Policy Regarding Motorized Recreation--The Forest leadership team agreed to a set of guidelines for the management of motorized recreation on the Forest, including the signing of roads for OHV use, special events, public involvement, use of trails, and improved communication about the program with users.

Recreation Master Plan--Development of this plan began only recently. The Plan will evaluate recreational uses and desires in order to develop a broad-scale strategy for recreational management on the Forest. The Plan is being developed collaboratively with interested publics to develop a list of recommendations to meet desired conditions, resolve user conflicts, and provide resource protection.

\section{Special Interest Area (SIA) Management Strategy}

The North Fork Smith Botanical Area is one of seven SIAs across the Forest designated for their unique botanical, ecological, or geological features. Many of the issues and user conflicts regarding management of the North Fork Smith Botanical Area also applied to the other SIAs on the Forest. The Forest decided to take a broad look at its management of all of the areas, and to collaborate with all interested publics in developing a strategy to guide their management.

The development of the SIA Management Strategy was one of the first efforts the Forest undertook in collaboration with public stakeholders. Because some of the public perceived Forest staff members as biased in one way or another, the Forest hired an outside facilitator to help manage the process and facilitate all of the public meetings. The Forest did not hold open public meetings, but rather invited all of the groups and individuals who had expressed their concerns over the previous 10 years. The facilitator asked each to participate, and also asked for the names of other people or groups who they thought would like to be involved.

Over 30 people attended the first meeting. At this meeting, Forest staff outlined the decision space for the group, and asked that the group provide input on how they use the areas, why they value each area, concerns about management of the area, and possible management activities that could resolve conflicts and achieve desired conditions. A Forest Service pathologist also gave a presentation about Port-Orford-cedar and the root disease, explaining how the disease is spread and what can be done to prevent the spread of the disease. 
Over the next eight months, a core group of about 20 people met six times. Members included representatives of environmental groups, botanical groups, OHV groups, mining claim holders, and individuals who like to recreate in these areas. This group listened to each other's interests and concerns, learned about the ecology of the areas, discussed ways to resolve user conflicts, and suggested possible actions to improve management of the areas. The groups agreed on almost all of the possible management activities, but could not agree on Port-Orford-cedar root disease prevention measures and access into the North Fork Smith Botanical Area. Instead, they developed a range of alternatives for access to the area, and asked for a team of Port-Orford-cedar experts to perform a site-specific risk assessment on the alternatives. They agreed that only alternatives with a low risk of introducing the root disease to the area should be carried forward into a site-specific NEPA analysis. Although the group could not come to resolution on access in the High Plateau area, they were very positive about the process. Many commented that they were glad to have the opportunity to hear and understand opposing points of view, and thought it was valuable for both "environmentalist and access people" to work on management strategies together.

\section{Assessing the Level of Risk to Port-Orford-Cedar in High Plateau}

In the fall of 1998, a team of two Forest Service Port-Orford-cedar experts visited the North Fork Smith Botanical Area and High Plateau. Since the Six Rivers Forest Plan was released, the Forest had remapped both Port-Orford-cedar and roads in the area, and the team combined this information with their on-the-ground observations to assess the level of risk for the alternatives developed by the public group. The team considered a number of factors in their risk assessment, including the value of Port-Orford-cedar, the hazard to the area if the disease was introduced, the level of exposure (e.g. number of vehicles, season of use, density of Port-Orford-cedar), and the susceptibility of PortOrford-cedar to the disease once exposed. Based on their analysis, the team decided that there were only two possible ways of achieving a low risk of introducing the root disease to the area: either close all the roads, or upgrade the roads to eliminate water from the road (bridges at low water crossings, improved drainage design to eliminate standing water and ruts). The latter option would also require removal of Port-Orford-cedar in close proximity to roads.

The results of the risk assessment meant that only one of the alternatives developed by the public group was implementable; all the others needed additional mitigations (e.g. road upgrades) in order to achieve a low risk. Ironically, the road upgrades would eliminate much of the challenge that makes the roads appealing to some OHV users. And the upgrades would make the area more accessible, thereby increasing the level of use, and possibly increasing the risk of introducing the root disease.

The Forest reviewed the risk assessment, and analyzed the costs associated with the mitigations needed to keep the roads open and achieve a low risk of introducing the disease to the area. After weighing a number of factors, the Forest proposed to close all the roads (18N09, 18N13, and the spurs off these roads) in the North Fork Smith Botanical Area year-round. Because the gates that are currently in place have been repeatedly vandalized, the closure would be implemented by removing sections of road rather than gating year-round. This proposal goes far beyond the Forest's typical protection measure of seasonal gating. If implemented, it would be the first year-round closure that also restricts administrative access.

\section{Why Propose A Year-Round Closure?}

Because of the sensitivity of the area, the Forest wanted to provide a higher level of protection in the High Plateau area than is typically provided elsewhere on the Forest. 
Many factors were considered in proposing to implement a year-round rather than a seasonal closure. These factors are highlighted below:

The closure is proposed within a botanical area that was designated specifically to maintain the ecological processes and unique botanical features of the area. A number of rare and endemic plants are found within plant communities associated with PortOrford-cedar. If the disease is introduced to the area, both Port-Orford-cedar and the plants associated with it could be negatively affected.

The National Forest Management Act requires the Forest to maintain viable populations of species, and the Smith River National Recreational Area Act requires the Forest to provide for the long-term viability and presence of Port-Orford-cedar.

The High Plateau, Bear, Peridotite Canyon, and Stony Creek watersheds form the largest remaining island of uninfested watersheds in the North Fork, Middle Fork, and Main Stem Smith River; they also form the largest island of uninfested watersheds in their ecological type, making this area an important refugia. The Forest believed that the need to protect these refugia, plus the threat to a variety of plant species, warranted a higher level of protection in this area.

Keeping roads within the area open would require extensive sanitation of Port-Orfordcedar located along roads in order to remove the host from the pathogen. Forest staff did not believe that large-scale removal of Port-Orford-cedar was in keeping with the goals and objectives for management within a botanical area, particularly because Port-Orfordcedar is associated with many of the unique plant communities for which the area was designated.

Forest staff estimated that it would cost between $\$ 275,000$ and $\$ 750,000$ to upgrade the roads, install stream crossings, and eliminate drainage problems. The Forest did not think that the low level of use of Roads $18 \mathrm{N09}$ and $18 \mathrm{~N} 13$ justified the level of investment needed to upgrade the roads.

Seasonal gates in the area have been repeatedly vandalized, and the remoteness of the area makes it difficult to check on the gates and enforce the closure.

\section{The Public Response}

Because the proposed action goes beyond standard Port-Orford-cedar protection measures and eliminates road access to the High Plateau area, the Forest knew that many people would be upset by the action, particularly the members of the SIA Management Strategy group who helped develop the alternatives for access in the High Plateau area. The first thing that Forest staff did was to invite them to a meeting in order to present the findings of the risk assessment and to explain the reasons for the Forest's proposed action. At the meeting, the risk assessment team discussed their assessment and findings, and the District Ranger told the attendees why he was proposing to close the roads. The public members who advocated for keeping roads in the area open did not like the proposal; however, a number of them said that they understood the Forest's dilemma between providing access and the need to protect Port-Orford-cedar from the root disease.

The Forest issued a letter to the public in June 1999. The letter described the proposed action to close the roads within the North Fork Smith Botanical Area, and asked for comments on the proposal. The Del Norte County Board of Supervisors held a public hearing regarding the proposal, and over 60 people attended. Many provided statements to the Board, both for and against the closures. 
When the Forest Service proposes an action, they typically hear primarily from those who oppose the action; people who support the action typically do not comment. However, the Forest heard from a number of people who did support this proposed action. Some of them cited recent introductions of the root disease into areas within the Kalmiopsis Wilderness and the Klamath River Basin as examples that the Forest Service's current mitigation measures are inadequate in preventing the spread of the disease. People who support the proposal believe that the road closures are the only effective means of preventing the spread of the disease into the area and protecting the unique character of the North Fork Smith Botanical Area.

Some of those who want to keep the roads open, see in the proposal, an attempt by the Forest Service to eliminate their access to their lands. They also fear that this closure will set a precedent, leading to year-round closures of other roads and other areas of the Forest to prevent the spread of Port-Orford-cedar root disease. Some of the people opposed to the road closures organized a petition and gathered hundreds of signatures to protest the proposed action. In recent Forest Service public meetings, some attendees have been quite hostile. One person threatened to dump buckets of infested soil in areas that the Forest is trying to protect, because the Forest typically does not gate areas that are already infested in the Smith River drainage.

Clearly, no amount of public involvement or education will be able to resolve this issue in a way that satisfies everyone, for it touches the core values of distinctly different publics; however, an agency whose mandate is multiple use cannot expect to always reach consensus on such thorny issues. A final decision on High Plateau has not been made.

\section{Literature Cited}

Beckham, S. 1971. Requiem for a people: the Rogue Indians and the frontiersmen. Norman, OK: University of Oklahoma Press.

Betlejewski, F. 1994. Port-Orford-cedar management guidelines. Portland, OR: U.S. Department of the Interior, Bureau of Land Management. $32 \mathrm{p}$.

Daniel, T.W.; Helms, J.A.; Baker, F.S. 1979. Principles of silviculture. New York: M.GrawHill. 500 p.

Gordon, D.E. 1974. The importance of root grafting in the spread of Phytophthora root rot in an immature stand of Port-Orford-cedar. Corvallis OR: Oregon State University; 116 p. M.S. thesis.

Gordon, D.E.; Roth, L.F. 1976. Root grafting in Port-Orford-cedar : an infection route for root rot. Forest Science 22:276-278.

Heffner, K. 1984. Following the smoke: contemporary plant procurement by the Indians of northwest California. Administrative report. On file with: Six Rivers National Forest, 1330 Bayshore Way, Eureka, CA. 95501.

Hendryx, M.; Hendryx, B.D. 1991. Plants and the people: the ethnobotany of the Karuk Tribe. Yreka, CA: Siskiyou County Museum.

Hoopa Tribal Forestry. 1994. Hoopa Valley Indian Reservation forest management plan for the period 1994-2003. Hoopa, CA: Hoopa Valley Tribe. Vol. 1. 
Jimerson, T.M. 1989. Snag densities in old-growth stands on the Gasquet Ranger District, Six Rivers National Forest, California. Res. paper. PSW-196. Berkeley, CA: U.S. Department of Agriculture, Forest Service, Pacific Southwest Forest and Range Experiment Station. 12 p.

Jimerson, T.M. 1994. A field guide to Port-Orford-cedar plant associations in northwest California. R5-ECOL-TP-002. Eureka, CA: U.S. Department of Agriculture Forest Service, Pacific Southwest Region, Six Rivers National Forest. 109 p.

Karuk Tribe of California. 1989. Karuk ancestral lands forest management plan. Prepared for Klamath and Six Rivers National Forests with Technical Assistance provided by Siskiyou Forestry Consultants, Arcata, CA. Karuk Tribe of California, Happy Camp, CA. Unpublished report. 59 p. On file with: Six Rivers National Forest, 1330 Bayshore Way, Eureka, CA. 95501 and Klamath National Forest, 1312 Fairlane Road, Yreka, CA 960979549.

Miller, T.; Kenetta, R. 1996. Confederated Tribes of Siletz History. Unpublished report. 3 p. On file with: The Confederated Tribes Siletz, 201 SE Swan Av Siletz, OR 97380.

Ostrofsky, W.D.; Pratt, R.G.; Roth, L.F. 1977. Detection of Phytophthora lateralis in soil organic matter and factors that affect its survival. Phytopathology 67:79-84.

Pacific Meridian Resources. 1996. Yurok Indian Reservation forest management plan. Prepared for the Yurok Tribe. Unpublished report. 35 p. On file with: The Yurok Tribe, 15900 Highway 101 N., Klamath, CA 95548.

Preister, K. 1994. Words into action: a community assessment of the Applegate Valley. Ashland, OR: Rogue Institute for Ecology and Economy. p. 68-69.

Preister, K. 1997. Public issues regarding the Scattered Apples project in Williams, Oregon. Ashland, OR: Social Ecology Associates. Unpublished report. 15 p. On file with the author, Social Ecology Associates, P.O. Box 3493, Ashland, OR 97520.

Shannon, M.; Sturtevant, V. 1995. Organizing for innovation: a look at the agencies and organizations responsible for adaptive management areas: the case of the Applegate AMA. Medford, OR: Report submitted to the Interagency Liaison, U.S. Department of Agriculture, Forest Service and U.S. Department of the Interior, Bureau of Land Management, Applegate Adaptive Management Area. 1995. On file with: Rogue River National Forest, Star Ranger District, 6941 Upper Applegate Road, Jacksonville, OR 97530.

Smith River National Recreation Area Act of 1990; 16 U.S.C. 460bbb et seq.

U.S. Department of Agriculture, Forest Service. 1995. Land and resource management plan, Six Rivers National Forest. Eureka, CA.

U.S. Department of Agriculture, Forest Service; U.S. Department of the Interior, Bureau of Land Management. 1994a. Applegate adaptive management area ecosystem health assessment. Medford, OR. 135 p.

U.S. Department of Agriculture, Forest Service; U.S. Department of Interior, Bureau of Land Management. 1994b. Final supplemental environmental impact statement on management of habitat for late-successional and old-growth related species within the range of the northern spotted owl. Portland, OR. $322 \mathrm{p}$. 
U.S. Department of Agriculture, Forest Service; U.S. Department of the Interior, Bureau of Land Management. 1995a. Applegate River watershed assessment: aquatic, wildlife, and special plant habitat. Medford, OR. $112 \mathrm{p}$.

U.S. Department of Agriculture, Forest Service; U.S. Department of the Interior, Bureau of Land Management. 1995b. Southwest Oregon late-successional reserve assessment. Medford and Grants Pass, Oregon. 150 p.

U.S. Department of the Interior, Bureau of Land Management. 1995a. Coos Bay District record of decision and resource management plan. North Bend, OR.

U.S. Department of the Interior, Bureau of Land Management. 1995b. Record of decision and resource management plan, Medford District. Medford, OR.

U.S. Department of the Interior, Bureau of Land Management. 1996a. Western Oregon transportation management plan. Portland, OR. 31 p.

U.S. Department of the Interior, Bureau of Land Management. 1996b. Williams watershed analysis. Medford, OR. 112 p.

U.S. Department of the Interior, Bureau of Land Management. 1998. Environmental assessment for the Williams Port-Orford-cedar management project. Medford, OR. $52 \mathrm{p}$.

Zobel, D.B.; Roth, L.F; Hawk, G.M. 1985. Ecology, pathology, and management of PortOrford-cedar (Chamaecyparis lawsoniana). General Technical Report PNW-184. Portland, OR: U.S. Department of Agriculture, Forest Service Pacific Northwest Forest and Range Experiment Station. $161 \mathrm{p}$. 


\section{Chapter 9 Methods of Assessing Risk}

Components of Risk Assessment. . . . . . . . . . . . . . . . . . . 127

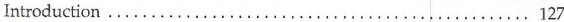

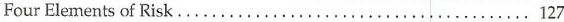

The Social Context of Risk ............................ 128

Range of Possible Strategies............................. 129

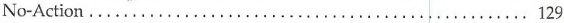

Slow the Rate of Infection . . . . . . . . . . . . . . . . . . . . . . . . . 129

Stop the Spread. ................................. 130

Eliminate P. lateralis ............................ 130

Evaluating Risk for Port-Orford-Cedar . . . . . . . . . . . . . . . . . . 130

After the Risk Analysis . . . . . . . . . . . . . . . . . . . . . . 132

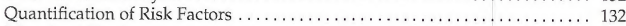

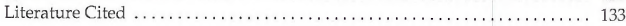

Authors: Thomas Atzet and Donald L. Rose 
A Range-Wide Assessment of Port-Orford-Cedar on Federal Lands 


\section{Components of Risk Assessment}

\section{Introduction}

Assessing ecological risk is complex. For example, how does one evaluate the risk of wildfire in an urban interface area or the spread of Phytophthora lateralis in a watershed? What is the objective and what is the potential for reaching that objective? Is it elimination of all risk, or some reduction in risk? What actions are possible? What is the cost of implementing those actions? What is the risk if nothing is done? Reducing risk assessment to four key elements helps to simplify the concept and evaluate alternatives for mitigation. The four essential elements of risk are: value, hazard, susceptibility, and exposure (fig. 9.1). Removing any of the four elements results in eliminating risk. The elements are interconnected and make up a "risk environment." Altering any element (risk management) alters the risk environment.

\section{Four Elements of Risk}

Value - To have risk, value must be involved. Port-Orford-cedar is valued for its utility, beauty, scarcity, and ecological function. Native American groups within the PortOrford-cedar region use the tree for many purposes. The Japanese have, in the past, placed a high value on the fine-grained, light textured wood. Port-Orford-cedar has been economically valued in the United States for its strength and resistance to decay. In the 1930s, concern about past and current harvest rates by the public and the Forest Service led to the establishment of "preserves." These areas, now known as the PortOrford-cedar and Coquille River Falls Research Natural Areas, were established in 1936 for scientific investigation, aesthetics, recreation, and concern for harvest rates, not for protection from P. lateralis (Tucker and Milbrath 1942).

If Port-Orford-cedar had no value, whether social, economic, ecologic, or spiritual, there would be no concern for its future. Spread of $P$. lateralis would be of no concern.

Figure 9.1. The four aspects of risk assessment.

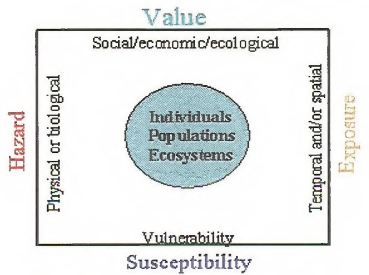

Assessment:

- Define value(s) as measurable variables that can be monitored

- Identify the hazard specifically (i.e. the spore is the hazard not vehicles)

- If measurable, quanti fy the probability of exposure (or qualify if only estimated)

- Is the individual or population susceptible to the frequency, intensity, and duration of exposure at its present extent, density and location?

Figure 9.1-The four aspects of risk assessment 
Hazard-P. lateralis is the hazard. It infects and kills trees. It is spread by vehicles, animals, and humans through infested soil and water; streams and roads act as corridors and habitat. On a large scale, it is highly unlikely that the hazard (disease) could be eliminated. Because of the flexibility in reproductive behavior, involving four methods of sexual and vegetative reproduction, elimination by direct action (i.e., applying pesticides) would be extremely difficult. The disease may be eliminated if the host - the Port-Orford-cedar - were eliminated, but that would not likely be tolerated by the public, and would change the ecological systems in which it occurs. Therefore, any attempt to eliminate the hazard on a large scale would be economically, socially, and biologically prohibitive.

Susceptibility-Susceptibility is a measure of the vulnerability of the object of value to the hazard. Some degree of resistance appears to be present in natural populations of Port-Orford-cedar, and may be enhanced genetically. The Port-Orford-cedar resistance and breeding program is working to produce genotypes with reduced susceptibility.

Currently most infections result in death. As research and development toward resistance proceeds, an appropriate, aggressive, operational assumption is that all individuals are susceptible and that infection is proportional to density of $P$. lateralis propagules.

Exposure-Exposure is an expression of the frequency, intensity, and duration that the host (Port-Orford-cedar) is in contact with the hazard (P. lateralis). In risk assessment, exposure must account for both time (temporal aspect) and location (spatial aspect). For example, if spores are deposited along a road once, the "frequency" of exposure is smaller than if many vehicles drive along a road, each depositing spores along the way. In another example, if vehicles are washed after leaving infested sites and before entering uninfested sites, the spore load is decreased and the "intensity" is decreased. Spatially, extent, location, and juxtaposition can be used to quantify exposure. Exposure is increased when an uninfested stand is adjacent to an infested stand (juxtaposition). Quarantine is primarily a spatial strategy whereby infested or non-infested areas are isolated. The extent of the pathogen is then minimized by using information on location and juxtaposition. Most strategies manipulate a combination of temporal and spatial occurrences of $P$. lateralis.

\section{The Social Context of Risk}

Practical goals concerning risk are determined within social constraints. Limits exist on what society is willing to pay and the level of risk they are willing to accept. For example, it is socially desirable to eliminate all traffic fatalities; however, regardless of the high value society places on life, traffic fatalities are accepted as part of the risk associated with driving. The resources that society is willing to commit, the restrictions they are willing to endure, and the risks they are willing to assume are value dependent (Cooray 1985). When stressed, individuals will violate restrictions and accept increased risk. If a speed limit of $15 \mathrm{mph}$ is shown to reduce traffic fatalities to near zero, some individuals, in a hurry, will drive faster and increase their risk of a fatal crash. Complete freedom, no restrictions and no risk, represents the most desirable scenario but the least attainable. Determining a strategy to balance restrictions with risk may be the next best option (fig. 9.2). With regard to control of $P$. lateralis, it is nearly biologically impossible to eliminate the pathogen on a large scale and it is unlikely to be economically feasible or socially acceptable. 


\begin{tabular}{|c|c|c|c|c|}
\hline & Gener & social contex & manageme & ategy \\
\hline & $\begin{array}{l}\text { Exterminate } \\
\text { Phytophthord } \\
\text { (Hazard mgt) }\end{array}$ & $\begin{array}{l}\text { Low ris } \\
\text { total eliput } \\
\text { is not potion ssible }\end{array}$ & $\begin{array}{l}\text { Estreme effort, } \\
\text { high allocation } \\
\text { of resources }\end{array}$ & $\begin{array}{l}\text { Low and/decreasing } \\
\text { social adceptance }\end{array}$ \\
\hline है & $\begin{array}{l}\text { Stop the } \\
\text { Spread }\end{array}$ & $\begin{array}{l}\text { Signific antly } \\
\text { Loprer ripk }\end{array}$ & $\begin{array}{c}\text { Effort depends } \\
\text { on scale } \\
\text { see below }\end{array}$ & $\begin{array}{l}\text { Moderate to } \\
\text { high social } \\
\text { acceptance }\end{array}$ \\
\hline 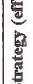 & $\begin{array}{l}\text { Slow the } \\
\text { Rate }\end{array}$ & risk & $\begin{array}{c}\text { Increasing } \\
\text { effort }\end{array}$ & $\begin{array}{l}\text { Increasing } \\
\text { acceptancd }\end{array}$ \\
\hline & No Action & $\begin{array}{l}\text { Accept eurrent } \\
\text { risk levels }\end{array}$ & & $\begin{array}{l}\text { Limited social } \\
\text { acceptarle }\end{array}$ \\
\hline & & Risk & Effort & Acceptance \\
\hline & Scope of application & & & \\
\hline & $\begin{array}{l}\text { - Spatial seale: tree - } \\
\text { - Temporal scale: seas } \\
\text { - Ownership: Federal } \\
\text { - Strategy areas: oper }\end{array}$ & $\begin{array}{l}\text { - drainage - landsc } \\
\text { - plan - life cycle - } \\
\text { te - private - all } \\
\text { ns - genetics - cons }\end{array}$ & \begin{tabular}{l|l} 
range & $\begin{array}{l}\text { A comb } \\
\text { on vari }\end{array}$ \\
scales \\
each ac
\end{tabular} & $\begin{array}{l}\text { of strategy areas } \\
\text { wnerships at various } \\
\text { be considered with } \\
\text { trategy. }\end{array}$ \\
\hline
\end{tabular}

Figure 9.2-The relationships of strategy to the risk, effort, and acceptance of implementing that strategy

\section{Range of Possible Strategies}

Figure 9.2 shows a range of possible strategies and qualifies the relationships between risk, effort, and acceptance. Some combination of any or all strategies may be an appropriate approach for attaining the range-wide, long-term goal of maintaining the ecological presence and economic viability of Port-Orford-cedar.

\section{No-Action}

A no-action strategy accepts the results of the ecological dynamics between PortOrford-cedar and $P$. lateralis within a changing environment. Historic experience with introduced pathogens infecting five-needle pines, elm, and chestnut indicates probable widespread mortality (even with control efforts) and diminished ecological and economic function (Merkel, 1905; Swingle, et al, 1949). Given that resistance to the pathogen appears only sporadically within natural populations of Port-Orford-cedar, the natural selection process in the genetic evolution of this tree species is unlikely to contribute significantly toward the goal of reducing the risk of infection in the short term.

\section{Slow the Rate of Infection}

The rate of infection may be slowed by low-effort, active or passive conservation strategies. These may include: 1) quarantining (isolating) infected or healthy trees, stands, or drainages; 2) washing vehicles; and 3) restricting seasonal access in certain areas. While isolating uninfested stands may lower their risk for exposure, this 
probability may be reduced if surrounding landowners do not cooperate. Operational measures such as washing vehicles or restricting access to areas has been a part of coordinated forest efforts and can slow infection rates (Goheen et al. 2000).

\section{Stop the Spreadl}

Scale is important to consider when defining a level of effort for "stopping the spread." If stopping the rate of spread is defined at the individual tree level, rather than by stand or drainage, then not one additional tree would become infected. This strategy would be impossible to monitor and difficult to achieve, but would have a high probability of lowering infection rates. Strategies might include increasing access restrictions, initiating more control measures, and performing intense sanitation (removal of host Port-Orfordcedar trees, especially along roadsides). Social acceptance may be limited with some of these measures.

\section{Eliminate $P$. lateralis}

Eliminating $P$. lateralis from the range of Port-Orford-cedar would be a long-term strategy and would require collaboration among all agencies, corporations, and private landowners. This situation may be similar to eliminating all traffic deaths. Developing methods to directly destroy $P$. lateralis would likely occur, as well as implementing methods to prevent reintroduction. The risk of $P$. lateralis to Port-Orford-cedar would be minimal to zero; however again, the necessary chemical, natural, and thermal methods might make these strategies socially unacceptable. Their effectiveness would be difficult and costly to monitor. Increasing restrictions and costs may lead to significant lowering of social acceptance.

\section{Evaluating Risk for Port-Orford-Cedar}

It has been established that Port-Orford-cedar has value. P. lateralis presents a hazard to Port-Orford-cedar. Currently almost all Port-Orford-cedar trees are susceptible to this hazard upon exposure. The immediate opportunity to manage risk in this situation comes from minimizing exposure of Port-Orford-cedar to P. lateralis. A long-term strategy includes breeding Port-Orford-cedar for reduced susceptibility (increased resistance) to $P$. lateralis.

The first step in a risk analysis is determining which of the four key elements (value, hazard, exposure, susceptibility) has potential for management. In the case of PortOrford-cedar, current opportunities exist for management of exposure.

Table 9.1 lists the factors that are correlated with Port-Orford-cedar exposure to infection. Each factor has been subjectively rated on importance to risk. The factors are rated high $(\mathrm{H})$, medium $(\mathrm{M})$, or low $(\mathrm{L})$ and are assigned a quantitative value of 3,2 , or 1 , respectively. Each factor is also rated and assigned a quantitative $(3,2$, or 1 ) value based on our ability to manage or control it. A "rank" is determined by adding the two quantitative ratings. The highest-ranking factors (in this case, the $6 \mathrm{~s}$ ) have a high risk along with a high level of ability to lower that risk. These factors would be a logical choice to use in a risk assessment.

The physical factors span the range in importance from low to high, but there is little opportunity to manage them, so the "control" rating is usually low. The risk from biological factors, roads and road related vectors, and harvest/extraction is often rated high or medium, and opportunities to control exposure often exist. The highest ranked factors are adjacent infection, recent dead Port-Orford-cedar, road surface, culverts, 
ditches, tree harvest method, and bough harvest. These deserve high priority when a risk analysis is done.

The next step requires defining a risk rating for each of the factors being considered. Suppose proximity to roads and proximity to infested areas are the factors being considered. We can define high-risk areas as those closer than 50 feet from a road. We may assign a quantitative value of 2 to these areas. Low risk areas would lie greater than 50 feet from a road and may have a quantitative value of 1 . High risk with regard to distance from an infested area may be defined as less than $100 \mathrm{feet}$, and assigned a value of 2. And low risk would be more than 100 feet from an infested area, with a quantitative value of 1 . Combining all combinations of the two factors would result in total risk values ranging from 2 to 4 , with 4 being the highest risk.

The next step is to apply these risk categories to an area. Areas could be mapped using the Geographic Information System (GIS) to delineate each of the risk areas, the 2s, 3s, and $4 \mathrm{~s}$. At this point, a map is available showing the risk areas and the next decision is whether or not to mitigate the risk and what methods are available.

Table 9.1-Factors that influence risk of infection of Port-Orford-cedar by P. lateralis, their level of risk (high, medium, or low), and our ability to change or control the level of risk (high, medium, or low)

\begin{tabular}{|c|c|c|c|}
\hline Influencing Factor & Risk & Control & Rank $^{*}$ \\
\hline Geologic rock type & $\mathrm{L}$ & $\mathrm{L}$ & 2 \\
\hline Average rank $=2.7$ & $\mathrm{~L}$ & L & 2 \\
\hline Aspect & $\mathrm{L}$ & $\mathrm{L}$ & 2 \\
\hline Slope steepness & $\bar{M}$ & $\mathrm{~L}$ & 3 \\
\hline Slope position microtopography & M & $\mathrm{L}$ & 3 \\
\hline Slope position macrotopography & M & $\mathrm{L}$ & 3 \\
\hline Soil moisture & M & $\mathrm{L}$ & 3 \\
\hline Drainage density & M & $\mathrm{L}$ & 3 \\
\hline Proximity to stream or water or flood - plains & $\mathrm{H}$ & M & 5 \\
\hline Annual Rainfall & $\mathrm{L}$ & $\mathrm{L}$ & 2 \\
\hline Average annual temperature & $\mathrm{L}$ & $\mathrm{L}$ & 2 \\
\hline Biological factors & $\mathrm{H}$ & $\mathrm{L}$ & 4 \\
\hline Port-Orford-cedar density, extent, juxtaposition & M & $\mathrm{H}$ & 5 \\
\hline Density or cover of other hosts & M & $\mathrm{H}$ & 5 \\
\hline Adjacent infection & $\mathrm{H}$ & $\mathrm{H}$ & 6 \\
\hline Adjacent infection of cultivars & $\mathrm{H}$ & $\mathrm{L}$ & 4 \\
\hline Recent dead (density and proximity) & $\mathrm{H}$ & $\mathrm{H}$ & 6 \\
\hline Seral stage & $\hat{L}$ & $\mathrm{H}$ & 4 \\
\hline Animal populations as vectors & $\mathrm{L}$ & $\mathrm{L}$ & 2 \\
\hline Roads and road related vectors & $\mathrm{H}$ & M & 5 \\
\hline Average rank $=4.8$ & $\mathrm{H}$ & $\mathrm{H}$ & 6 \\
\hline Proximity to road & $\mathrm{H}$ & M & 5 \\
\hline Other road design factors (usually drainage) & M & M & 4 \\
\hline Culverts & $\mathrm{H}$ & $\mathrm{H}$ & 6 \\
\hline Ditches & $\mathrm{H}$ & $\mathrm{H}$ & 6 \\
\hline Traffic density & $\mathrm{H}$ & M & 5 \\
\hline Traffic type & M & $\mathrm{H}$ & 5 \\
\hline Right-of-way agreements & M & $\hat{L}$ & 3 \\
\hline Off-road vehicle traffic & $\mathrm{H}$ & M & 5 \\
\hline Trails (same as roads) & M & $\mathrm{H}$ & 5 \\
\hline Fishing traffic & $\mathrm{L}$ & $\mathrm{L}$ & 2 \\
\hline Harvest/Extraction & M & $\mathrm{H}$ & 5 \\
\hline Average rank $=5.3$ & $\mathrm{H}$ & $\mathrm{H}$ & 6 \\
\hline Bough harvest & $\mathrm{H}$ & $\mathrm{H}$ & 6 \\
\hline Mining & $\mathrm{H}$ & $\mathrm{L}$ & 4 \\
\hline Opportunities to control exposure & M & $\bar{L}$ & 3 \\
\hline Average rank $=3.0$ & $\mathrm{~L}$ & M & 3 \\
\hline
\end{tabular}




\section{After the Risk Analysis}

Additional factors must be considered after the risk analysis to determine whether or not action is to be taken and if so, what action. If the cost of treatment is high, it may prohibit any action regardless of the risk. Social acceptance must also be considered, especially on public land.

\section{Quantification of Risk Factors}

As risk analyses become more sophisticated, the values assigned to help quantify risk will become more accurate.

For example, Jimerson (1999) has shown a highly significant difference between infested and uninfested stands based on slope position. In California, stands in riparian areas are much more likely to have Port-Orford-cedar infected with P. lateralis. Infested and uninfested stands are significantly different in mean distance from roads. Infested stands average 52 feet and uninfested stands 139 feet from a road. Distance from the Pacific Ocean (an integration of several environmental factors, including fog, moisture, temperature, etc.) and elevation also differed between infested and uninfested stands. Mean distance from the ocean was 14 miles for infested and 24 miles for uninfested stands. Mean elevation for infested stands was 475 feet and for uninfested stands, 866 feet. As means, these values can be used to assign high-risk and low risk categories.

Regression analysis expresses the relationship between two or more continuous variables, for example, the percentage of a stand that is infested and the elevation of that stand. As presented above, the average uninfested stand is higher in elevation than the average infested stand. If we could sample several stands and develop a model (regression) of the relationship between these two variables, we could assign stand risk values more precisely than simply high risk-low risk.

In biological systems, usually several variables interact with each other. For example, elevation and distance from the ocean may give a better estimate of infested stands than either variable alone. This could be modeled with multiple regression techniques.

Most relationships are not likely to be linear and may display thresholds, limits, maximums, and minimums. In such cases, even when the relationship is relatively weak, it may be useful. 


\section{Literature Cited}

Cooray, L.J.M. 1985. Risk avoidance, freedom of choice or government coercion. In: Human rights in Australia. Sydney, Australia: ACFR Educational Publications. Chapter 11.

Goheen, D.J.; Marshall, K.; Hansen, E.M.; Betlejewski, F. 2000. Effectiveness of vehicle washing in decreasing Phytophthora lateralis inoculum: a case study. SWOFIDSC-00-2. Central Point, OR: U.S. Department of Agriculture, Forest Service, Southwest Oregon Insect and Disease Service Center. $7 \mathrm{p}$.

Jimerson, T.M. 1999. A conservation strategy for Port-Orford-cedar. Unpublished paper. On file with: Siskiyou National Forest, 333 West 8th St. Medford OR 97501.

Merkel, H.W. 1905. A deadly fungus on the American chestnut. New York Zoological Society. 10th Annual Report: 97-103.

Swingle, R.U.; Whitten, R.R.; Brewer, E.G. 1949. Dutch Elm disease. In: Yearbook of agriculture. Washington D.C.: U.S. Department of Agriculture, U.S. Government Printing Office.

Tucker, C.M.; Milbrath, J.A. 1942. Root rot of Chamaecyparis caused by a species of Phytophthora. Mycologia. 34:94-103. 


\section{Chapter 10}

Management Techniques and Challenges

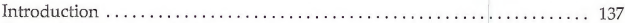

General Management Techniques ......................... 137

Operational Planning and Scheduling ................. 137

Integrating Disease Treatments with Road Design, Engineering,

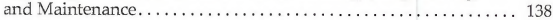

Water Source Selection and Treatment .................. 141

Regulating Non-Timber Uses. . . . . . . . . . . . . . . . . . . . 141

Educational Efforts $\ldots \ldots \ldots \ldots \ldots \ldots \ldots \ldots \ldots \ldots \ldots \ldots \ldots \ldots, 142$

Prescribed Fire Potential . . . . . . . . . . . . . . . . . . . . . 143

Genetic Resistance Breeding Development ................ 144

Specific Management Techniques . ........................... 144

Vehicle Exclusion ................................. 144

Temporary Road Closures ......................... 146

Roadside Sanitation............................. 147

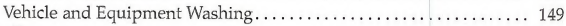

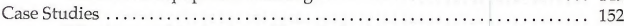

Effectiveness Monitoring of Port-Orford-Cedar Roadside Sanitation

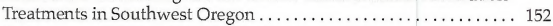

Effectiveness of Vehicle Washing in Decreasing Transport of

P. lateralis Inoculum. ........................... 153

Managing Port-Orford-Cedar in Areas Not Favorable to the Pathogen . . . . . 154

Managing Port-Orford-Cedar in Areas Favorable to the Pathogen .... . . . . 155

Manipulating Species Composition .......................... 156

Management Challenges............................... 156

Difficulty of Monitoring Effectiveness of Management Activities ... 156

Few Opportunities to Obtain New Management-Related Research

Results................................ 156

Public Opposition to Agency Management Activities ........... 157

Coordination Difficulties .......................... 157

Funding Uncertainties. . . . . . . . . . . . . . . . . . . . . . 157

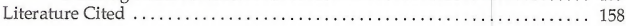


A Range-Wide Assessment of Port-Orford-Cedar on Federal Lands 


\section{Introduction}

This chapter is a discussion of possible treatment alternatives that can be used alone or in combination. In general, land managers seek to maintain Port-Orford-cedar as a part of the forest ecosystem and reduce the occurrence of Phytophthora lateralis. The determination of appropriate management regimes is the choice of the local manager, dependant on site conditions and applicable land use objectives.

In the first three decades after the introduction of $P$. lateralis, few, if any, attempts were made to manage Port-Orford-cedar root disease. The striking virulence of the exotic pathogen and the speed with which it spread along roads and streams as well as the obvious tie between spread, and then-practiced timber harvesting techniques, led to statements such as "there appears to be no hope of raising another crop of Port-Orfordcedar under existing conditions of disease and land use" and production of Port-Orfordcedar "... will likely decline and ultimately drop to nearly nothing as the remaining merchantable trees die or are harvested" (Roth et al. 1972). Many felt that with the pathogen established, active management of Port-Orford-cedar, as a timber species, was no longer possible. Emphasis was placed on extensive salvage of large disease-killed cedars.

Management for Port-Orford-cedar root disease has changed dramatically in the past 30 years. Many forest managers on federal lands administered by the Forest Service and the Bureau of Land Management are now involved in an integrated program to minimize detrimental impacts of the root disease. The difficulties, expenses, and inconveniences associated with managing Port-Orford-cedar are carefully weighed against the need and potential for limiting the spread of the disease.

While P. lateralis has caused negative impacts on Port-Orford-cedar populations, the severity varies. In spite of concerns early in the epidemic, the natural range of PortOrford-cedar has not diminished because of the root disease and the species has not been extirpated from any major area where it has historically been located (Kliejunas 1994). Management techniques discussed in this chapter have been shown to be effective in lessening the occurrence of $P$. lateralis and maintaining Port-Orford-cedar population viability.

\section{General Management Techniques}

\section{Operational Planning and Scheduling}

Planning access routes and timing projects to minimize the likelihood of $P$. lateralis spread have been routinely suggested as Port-Orford-cedar root disease management techniques and are widely practiced (Erwin and Ribeiro 1996, Goheen et.al. 1997, Harvey et al. 1985, Kliejunas 1994, Roth et al. 1987, Scharpf 1993, Thies and Goheen in press, USDA 1983, Zobel et al. 1985).

Separating forest operations in diseased stands from those in disease-free locations, both in space and time, is a common technique that can be applied to minimize the likelihood of $P$. lateralis spread. 
When the local land manager chooses this techuique, forest management projects in stands with Port-Orford-cedar, especially in uninfested areas, are typically performed when conditions are unfavorable for pathogen survival and spread. The following practices may be implemented:

- Projects are preferentially scheduled to be completed in the warm, dry months and are discontinued when wet conditions develop, even during the stated operating season.

- Repeated entries into vulnerable microsites are avoided, and work is scheduled to proceed sequentially, from uninfested to infested sites.

- Equipment is not allowed to move from an infested area into an uninfested one.

- Access to project areas is generally planned along routes with the least occurrence of infested sites.

There is abundant evidence that spread of $P$. lateralis is associated with timber harvesting operations that have not addressed timing and access of harvest operations. (Roth et al. 1972, Trione 1959). Where timber-harvesting operations are conducted in stands with Port-Orford-cedar or where streams intersect stands with Port-Orford-cedar below harvest units, systems that minimize the amount of soil movement, especially across slope movement, help minimize the spread of $P$. lateralis.

Use of cable systems or helicopter logging systems lowers the risk of spread compared to tractor-logging systems. Where possible, root disease prevention and management activities can be coordinated with adjacent landowners.

Some forest management projects are limited to wetter periods of the year. Examples include tree planting, prescribed burning, and surveys for certain survey and manage species. Managers may consider precautions such as washing vehicles and other equipment, avoiding routes that pass through infested areas, and walking to project sites rather than driving in such cases.

\section{Integrating Disease Treatments with Road Design, Engineering, and Maintenance}

Minimizing the risk of $P$. lateralis spread is an important consideration in designing and building new roads and in maintaining or improving existing roads in areas with PortOrford-cedar.

For new construction, routing decisions could be made with the knowledge of where Port-Orford-cedar concentrations occur. The risk of the spread of $P$. lateralis can be minimized when new roads or spurs are located below known concentrations of PortOrford-cedar, or on the opposite sides of ridges.

In new road construction, culverts and waterbars are designed to quickly direct water into existing well-defined water channels away from areas where Port-Orford-cedars exist. Roads may be insloped, and, in some cases, site-specific berms may be used on the outside edges of roads to prevent downslope flow of water. Reshaping of existing roads is sometimes done to create a convex profile. 
Risks may further be reduced during road building and maintenance when:

- Road building and maintenance is restricted as much as possible to the dry season and cleaned equipment is used.

- Movement of soil and debris from one place to another during construction or maintenance is minimized.

- Side-casting material into drainage ditches, streams, or over road berms during maintenance along road segments with infected trees is avoided.

- Clean rock (treated rock or rock from disease-free quarries) is selected over river rock.

- Clean rock or pavement is added to existing roads to raise those sections of roadbeds that pass through infested sites.

- Surfacing materials are applied to natural surface roads in areas with P. lateralis to reduce the likelihood of vehicle tires coming into contact with infested soil (fig. 10.1).

- Stream crossings on new roads are designed to keep vehicles out of contact with water, and primitive roads that cannot be closed are upgraded so that fords and puddles are eliminated.

- Care is taken in moving soil and other material when end-hauling, repairing flood damage, or removing slides, especially in, or near, infested areas.

Road systems and drainages are the main avenues by which $P$. lateralis invades new areas. The battery of management techniques available to the manager in new road construction and maintenance seeks to: 1) limit the likelihood that vehicles will pick up, carry, and deposit contaminated soil along roads and in cross drainages; 2 ) minimize direct movement of infested soil in road building and upkeep; and 3) where possible, decrease exposure of Port-Orford-cedars to roadside influences by design and location. Road treatments have been frequently suggested and used as parts of Port-Orford-cedar root disease management (Betlejewski 1994, Goheen et al. 1999, Hansen et al. 1999, Kliejunas 1994, Roth et al. 1987, Thies and Goheen in press, Zobel et al. 1985).

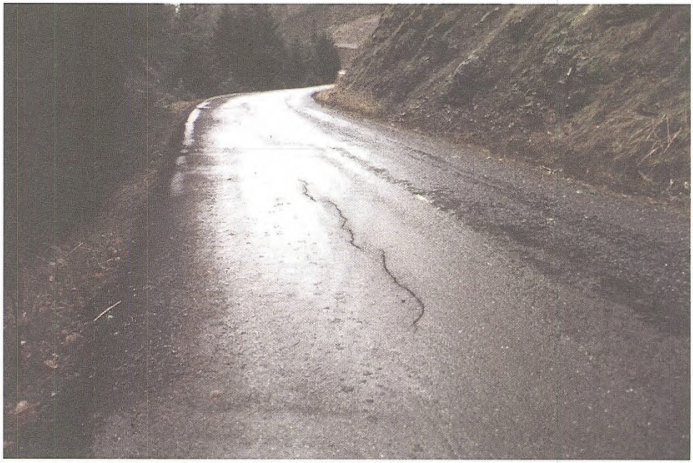

Figure 10.1-Surfaced roads reduce the likelihood of spreading Phytophthora lateralis 
Use of road design, engineering, and maintenance techniques for Port-Orford-cedar disease management requires understanding and commitment by the organizations and individuals involved in the development, building, and maintenance of roads. Problems sometimes arise in emergency situations when quick repairs are needed.

Many of the road systems on federal lands were originally engineered and built when opportunities to incorporate Port-Orford-cedar root disease management treatments were not recognized. Such efforts as reshaping road surfaces for improving drainage, adding aggregate rock, paving, or improving stream crossings, are expensive. Cost limits their use. When considering upgrading roads to decrease risk of P. lateralis spread, the possibility that road improvements will encourage much greater road use can be considered and weighed in determining whether or not to implement the project.

Reciprocal Right-of-Way Agreements (RWAs) have played important roles in the administration of the Oregon and California Act $(O \& C)$ lands of western Oregon since the early 1950's. A RWA is basically an exchange of access rights between a private timberland owner and the United States. In a RWA, each party grants to the other the right to construct roads on the other party's land and the right to use existing roads for certain purposes owned or controlled by the other party. Guaranteed access to Federally-owned timber offered for sale by the Bureau of Land Management encourages competitive bidding among private timber companies. The rights granted or received in a RWA are for forest management activities and the transportation of forest or mineral products. A RWA does not necessarily include access rights for the public. Each RWA is unique, bounded by the applicable laws and regulations in place at the time the RWA is signed.

Although BLM roads are available for use by the public, they are not "public roads" as defined by State statute ORS 386.010(2). BLM roads are considered "private government roads" and the agency retains the authority to control activities on these roads including use by the general public. BLM roads are subject to closure by the agency for public safety and environmental protection reasons. An example would be closure during periods of extreme fire danger. The BLM requires permits for the use of these roads for commercial purposes. Terms and conditions of a RWA cannot be modified without approval by both parties to the agreement.
Greatly increased road use may offset disease management benefits achieved by the treatments.

Road management techniques may be less effective under the checkerboard ownership pattern that is found on most western Oregon BLM lands and many northern California Forest Service lands. In western Oregon, on BLMadministered lands, many roads are covered by Reciprocal Right of Way Agreements (fig. 10.2). These agreements are legal contracts that may constrain road management techniques. $B L M$ roads covered by these agreements require concurrence from the private entity that is party to the agreement prior to any road management activity implementation not specifically addressed in the agreement.

Figure 10.2-Reciprocal Right of Way Agreements 


\section{Water Source Selection and Treatment}

Once $P$. lateralis has been introduced into a stream or body of water, there is always the possibility that propagules of the pathogen can be taken up and transferred with water from that source. Propagules are especially likely to be numerous if current or recent root disease-caused mortality and decline in cedars is readily detectable adjacent to the water; but they also may be present even in areas where all mortality appears to have occurred years previously. If water is taken only from sources that exhibit no evidence of root disease, probability of spreading propagules of the pathogen in water is reduced. Using water from uninfested sources for forest use has been suggested as a component of PortOrford-cedar root disease management (Goheen et al. 1999, Hansen et al. 1999, Roth et al. 1987).

Many water sources have been inventoried and those that are potentially infested by $P$. lateralis have been identified. Subsequently, when water is needed for activities such as road construction, fire fighting, or dust abatement, uninfested water sources can be used when possible. Where disease-free water sources are not available and water must be taken from a potentially infested source, it can be treated with Clorox@ Ultra Institutional before use ( 1 gallon of Clorox $®$ to each 1,000 gallons of water). In areas where water sources have not been inventoried, Clorox® can also be used.

Adding chlorine bleach to $P$. lateralis-infested water will kill many propagules of the pathogen. Murray et al. (1995) demonstrated that complete mortality of $P$. lateralis zoospores occurred after 60 minutes in 100 parts per million (ppm) chlorine bleach, and complete mortality of chlamydospores occurred after 30 minutes in $5000 \mathrm{ppm}$ chlorine bleach. Clorox is registered for use in forest environments in California and Oregon.

Chlorine bleach, however, will not kill $P$. lateralis in infected rootlet fragments at any concentration (Murray et al. 1995). If mud is stirred up to any extent before an intake hose is placed into the water, suspended organic particles containing $P$. lateralis propagules may be taken up in spite of precautions taken with placement of the hose. Risk is minimized when bottom disturbance is avoided.

\section{Regulating Non-Timber Uses}

A number of special use activities including Port-Orford-cedar bough collecting, mushroom picking, salal gathering, grazing, and mining occur on federal forest lands and have potential to influence the spread of $P$. lateralis. Several of these activities involve extensive vehicle travel, and can involve vehicle movement from infested to uninfested areas. And some, especially bough collecting and mushroom hunting, are preferentially engaged in at times of the year when the cool, wet conditions most favorable for spread of the pathogen prevail. There is considerable anecdotal evidence associating bough collecting with the spread of P. lateralis.

Concerns about spreading $P$. lateralis with special use activities are similar to those associated with forest management projects, but special use activities are much more difficult to regulate. 
The following permit restrictions may be selected by managers to help to minimize the spread of $P$. lateralis:

- specify where activities can be done;

- regulate the sequence of operations;

- determine the appropriate timing of activities with the objectives of limiting PortOrford-cedar root disease spread;

- inform permitees about the disease and the need to cooperate with disease management requirements.

Difficulties associated with controlling special use activities include:

- lack of cooperation by some permitees;

- difficulty in tracking often widely scattered, transient, non-systematic operations

- language barriers with some workers;

- shortages of trained agency personnel for monitoring activities and enforcing regulations;

- laws that limit the degree to which some activities can be regulated on public lands (example: mining).

Recreationists, including hikers, mountain bike riders, horseback riders, hunters, offroad vehicle users, and campers also have potential to spread P. lateralis. Those involved in these pursuits are more difficult to monitor and regulate than special use permitees. Federally-sanctioned recreation activities may have specific, enforceable rules aimed at decreasing risk of disease spread.

\section{Educational Efforts}

Humans are responsible for most of the spread of $P$. lateralis. Many people inadvertently aid its spread due to lack of knowledge and understanding. A surprising number of forest users, including forest workers as well as recreationists, are not aware of the significance of the pathogen's adverse impacts on the forest. Some know about PortOrford-cedar root disease but do not fully appreciate the implications of their own activities in spreading the disease organism.

Federal agencies are making extensive efforts to disseminate information on the biology and ecology of $P$. lateralis, with emphasis on how the pathogen spreads and how its spread can be prevented. Presentations at training sessions, workshops, and symposia, as well as newspaper articles, television interviews, pamphlets, journal articles, displays at public functions, classroom teaching materials, and information signs at BLM offices, Ranger Stations, visitor information centers, campgrounds, trail heads, and along forest roads are used.

Problems associated with current educational efforts include:

- difficulties in convincing people that their individual activities really can have effects on spread of the root disease organism (the "who me?" syndrome);

- difficulty in reaching the groups most in need of receiving the information, for example, off-road vehicle users or miners;

- problems disseminating information to non-English speaking individuals;

- challenges associated with making material interesting and/or readable;

- getting needed information across to large numbers of people within a short time period or with a limited amount of written material. 
Of particular importance in the educational effort is reaching federal, state, and county agency employees. Not only do these employees spend considerable amounts of time in the forests where the spread of Port-Orford-cedar root disease is of most concern, members of the public also frequently observe them. If informed employees follow management direction for minimizing the spread of $P$. lateralis, they will directly influence others, encouraging them to do the same. Their examples will also demonstrate the commitment of the agencies to follow their own recommendations.

\section{Prescribed Fire Potential}

Use of prescribed fire as part of Port-Orford-cedar root disease management has been discussed, but not thoroughly investigated. In theory, fire could decrease or even eliminate $P$. lateralis on a site by killing hosts, as well as reducing or eliminating inoculum in the soil.

Use of fire for vegetation management or hazard reduction is routinely prescribed in many forested areas. Fire is a natural disturbance agent in many plant communities where Port-Orford-cedar occurs; prescribed fire may mimic the less severe, natural disturbance events that occurred historically.

Large Port-Orford-cedar trees are thick-barked, fire resistant, and can survive fire as well as mature Douglas-fir; young Port-Orford-cedar, however, are readily killed by even low intensity fires (Zobel 1990). P. lateralis does not infect dead trees, and killing all hosts in a strategic location is the basis for the sanitation treatments described later in this chapter. In certain situations, prescribed burning may be a way to accomplish this objective, especially when only small cedars are to be treated. Fire is being tested as a way to treat or retreat roadside sanitation segments where Port-Orford-cedars have reseeded in substantial numbers. Another potential treatment is the application of extremely hot water. $^{25}$

$P$. lateralis itself is very sensitive to heat. It has been demonstrated that survival of the pathogen is minimal in soil exposed to temperatures of $104^{\circ} \mathrm{F}$ or greater, especially if conditions are dry (Hansen and Hamm 1996). If prescribed fires can generate temperatures in this range at sufficient depths in the soil to reach roots and organic material that are harboring the pathogen, it could significantly reduce or eliminate $P$. lateralis inoculum. In one trial (DeNitto 1992), soil baiting ${ }^{26}$ was used to evaluate the effects of fire on P. lateralis in soil following a fire. In this case, the fire was of low intensity and temperatures did not exceed $100^{\circ} \mathrm{F}$ at a depth of 4 inches. The pathogen was recovered after the fire at the same level as before treatment. Effects of higher intensity fires have not yet been evaluated. Burn areas with substantial amounts of woody material, especially material that is greater than three inches in diameter, can be expected to generate higher intensity fires than that evaluated by DeNitto.

If prescribed burning proves effective and is implemented as a Port-Orford-cedar root disease management tool, certain precautions could be taken:

- use uninfested or treated water and equipment;

- units will be sequenced so that all uninfested units are treated before infested units in a project;

\footnotetext{
${ }_{25}$ Casavan, K. 1999. Personal communication. Natural Resource Specialist, Roseburg District Office, 777 Garden Valley Boulevard, Roseburg, OR 97470.

${ }^{26}$ Baiting is a type of bio-assay that uses Port-Orford-cedar seedlings to determine the presence of Phytophthora lateralis. Non-resistant PortOrford-cedar seedlings are planted in soil or placed in streams where P. lateralis is suspected to occur. After an exposure period of four to eight weeks, the seedlings are recollected and examined for cambial stain, a diagnostic symptom of infection by P. lateralis. To confirm the diagnosis, root tissue from a subsample of seedlings is cultured on a selective media and examined under a microscope for the sporangia characteristic of $P$. lateralis.
} 
- fire lines around prescription areas could be constructed using techniques that do not cause undesired changes in drainage patterns;

- fall or remove trees or snags to facilitate burning.

\section{Genetic Resistance Breeding Development}

An intriguing, long-term potential disease management option is the development of Port-Orford-cedar that are resistant to P. lateralis. Development of resistant Port-Orfordcedar stock could be especially valuable to managers attempting to restore the species in heavily impacted riparian areas. Host resistance has proven to be an especially effective disease management technique for use against many other Phytophthora species (Erwin and Ribeiro 1996, Umaerus et al. 1983). In 1989, evidence of resistance in natural PortOrford-cedar populations was first demonstrated at Oregon State University (Hansen et al. 1989), and the Forest Service and BLM are now actively involved in a resistance enhancement-breeding program.

Results of the breeding effort so far are encouraging; however, there is no guarantee that usable resistance will result. There are several factors that will determine whether or not resistant Port-Orford-cedar will be used. These include: 1) durability of resistance; 2) practicality of producing stock (cost); 3 ) match of resistant material to appropriate seed zones and sites; 4) mechanisms of resistance involved, and, in some cases; 5) quality of resistant trees (e.g., form, growth rates). Managers with different objectives will have different priorities for these factors, but each will probably be concerned with most or all.

Port-Orford-cedar resistant stock will not be immune to P. lateralis. Rather, it will tolerate infection. If such stock is planted on an infested site, some level of infection will occur, and inoculum will be maintained even though many planted trees survive. Therefore, there is some concern about establishing resistant trees in certain situations. For example, in infested areas adjacent to heavily used roads, planting resistant stock might maintain inoculum that could be picked up and spread by vehicles. In such cases, having no Port-Orford-cedar would be better. Another example would be adjacent to uninfested natural stands where resistant trees could act as inoculum bridges, allowing spread of the pathogen.

\section{Specific Management Techniques}

\section{Vehicle Exclusion}

Vehicle exclusion is a quarantine technique that may be used to protect Port-Orford-cedar by preventing vehicle entry. If a manager chooses this technique, new roads are not built in uninfested areas, and existing roads are permanently closed (fig. 10.3). Road closures are done in ways that vehicles cannot broach them or detour around them. Large berms, "tank traps," or rock piles are strategically located at sites where it is virtually impossible to bypass them (fig. 10.4). Alternatively, roads may be completely obliterated. 


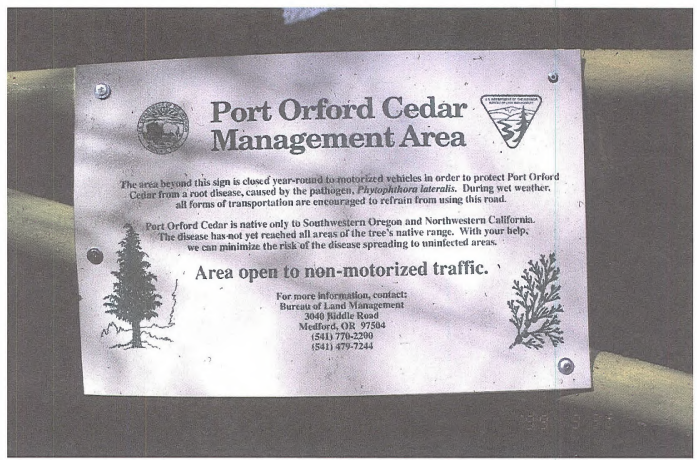

Figure 10.3-Road closure sign

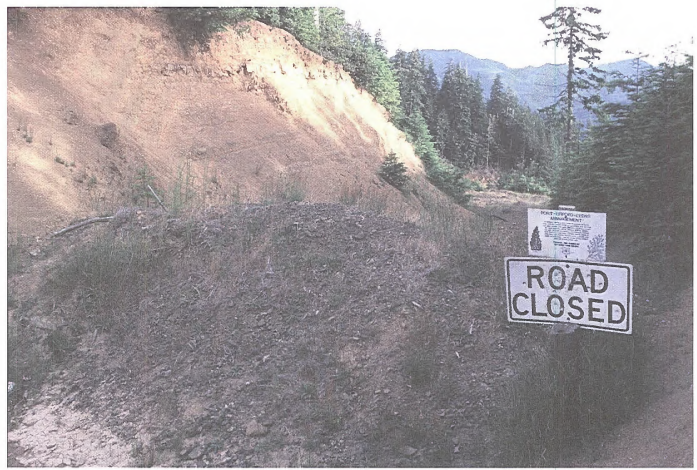

Figure 10.4-Road closed to prevent the spread of Phytophthora lateralis (permanent closure) 
If vehicle exclusion is selected, to be truly successful it should be practiced in a location that can be protected. Effectiveness has not been documented by systematic monitoring, but is supported by numerous, long-term observations.

When selected as a management technique, exclusion is best used where an entire drainage, or at least the upper portion of a drainage, can be treated as a unit. Exclusion is not likely to be useful in the lower portions of drainages if the upper portions are not also protected. Closing individual roads to prevent spread at lower elevations makes little sense if other roads higher up in the same drainages remain open.

Exclusion can be a controversial management technique. Some sectors of the public consider prevention of vehicle access to constitute an infringement on their rights to use public lands. Closing already existing roads is particularly unpopular. Legal precedents may make closing some roads difficult or impossible. Closing roads is often not an option, particularly where federal lands occur in checkerboard patterns interspersed with privately owned lands. Right-of-Way agreements that govern use of these roads usually prevent agencies from unilaterally denying access to land owners who have previously entered into a right-of-way agreement.

\section{Temporary Road Closures}

Like exclusion, temporary road closure (fig. 10.5) seeks to protect Port-Orford-cedar by preventing vehicles from spreading $P$. lateralis propagules into uninfested areas. It differs from total exclusion by allowing controlled road use into vulnerable areas during times when conditions are unfavorable for establishment and spread of the pathogen. If a manager chooses this technique, roads are closed during the cool, wet season of the year, typically from October 1 to June 1. In addition, special closures may be applied during particularly wet periods at other times of the year (June through September). Roads can be closed with locked gates, guardrails, or other movable barriers, and closures are located in areas where they are difficult to bypass.

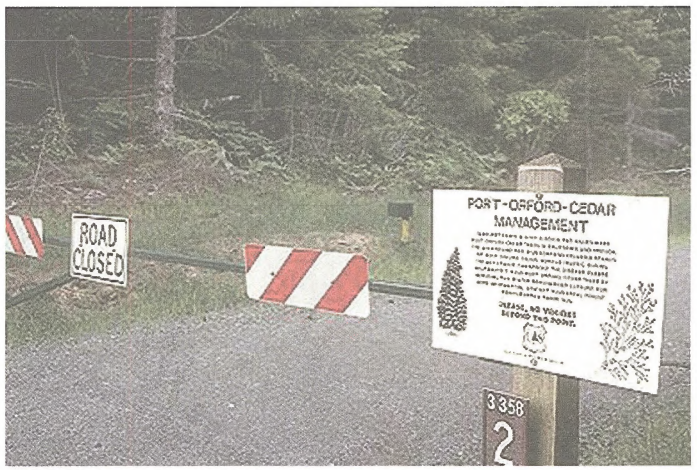

Figure 10.5-Road closed to prevent spread of Phytophthora lateralis (temporary closure) 
Temporary road closures require considerable attention to ensure that they are indeed in place when they need to be (during wet, cool periods at any time of year) and that they are not breached. Placement and strength of barriers are important considerations in use of temporary closures, as is constant vigilance. Because roads are still present beyond the closures, people in some areas have found ways around the closures, or have forced open or destroyed gates or other structures to gain access. Gate vandalism and the associated costs of repairing or replacing gates can be a major drawback of this technique.

Closing roads during the cool, moist season in uninfested areas keeps the probability of disease introduction and spread low. Research has demonstrated that successful spread and establishment of $P$. lateralis occurs when moist conditions prevail and temperatures are between $50^{\circ} \mathrm{F}$ and $68^{\circ} \mathrm{F}$. These functions decline greatly as temperatures increase to $79^{\circ} \mathrm{F}$ and, under dry conditions, there is little activity of the organism at any temperature. Under dry, warm conditions, even survival of chlamydospores is greatly reduced (Hansen and Hamm 1996, Ostrofsky et al. 1977, Trione 1974, Tucker and Milbrath 1942).

Because of these temperature and moisture requirements, initiation of new P. lateralis infections occur almost entirely in the rainy and cool late fall, winter, and early spring months and very little in the warm, dry months. Flexibility to close roads during the summer months if unusual wet, cool conditions develop can further reduce probability of spread. Temporary road closure has been widely suggested as a Port-Orford-cedar root disease management technique (Betlejewski 1994, Goheen et al. 1997, Goheen et al. 1999, Hadfield et al. 1986, Hansen and Hamm 1996, Hansen and Lewis 1997, Hansen et al. 1999, Harvey et al. 1985, Nielsen 1997, Roth et al. 1987, Thies and Goheen in press, Zobel et al. 1985).

\section{Roadside Sanitation}

Roadside sanitation is a potential management technique that eliminates Port-Orfordcedar in buffer zones along both sides of a treated road (fig. 10.6). Silviculture texts define sanitation as "the elimination of trees that have been attacked or appear in imminent danger of attack by damaging insects or pathogens in order to prevent these agents from spreading to other trees" (Smith 1962, Daniel et al. 1979).

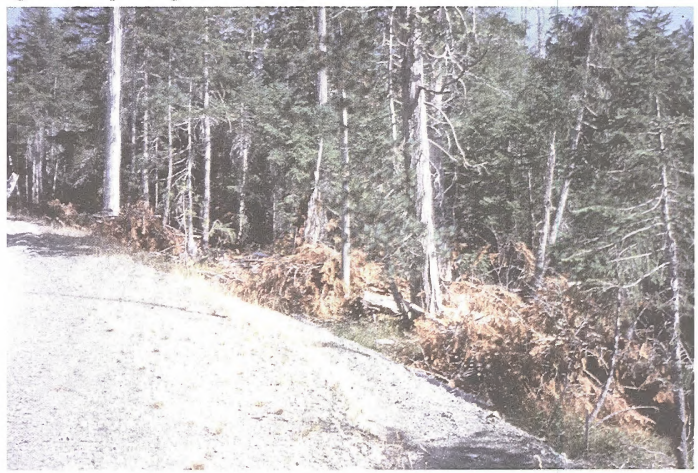

Figure 10.6-Roadside sanitation treatment to help prevent the spread of Phytophthora lateralis 
The objectives for sanitation treatments are either 1) preventing new infections along roads that cannot be closed in currently uninfested areas; or 2) eliminating or minimizing the amount of inoculum readily available for vehicle transport from already-infested roadsides. The key feature of a sanitation treatment with either objective is to create a zone where live Port-Orford-cedar roots are absent.

Roadside sanitation is believed to be effective because $P$. lateralis only infects living hosts. The pathogen can survive in the roots of dead trees that were infected while alive, but it cannot colonize the roots of already dead Port-Orford-cedars. Therefore, if all living PortOrford-cedars are killed in an infested area and establishment of new host regeneration can be prevented, the amount of inoculum should progressively decrease on the site and eventually disappear. Hansen and Hamm (1996) demonstrated that P. lateralis could survive in dead infected roots for up to seven years under ideal environmental conditions; under more typical conditions it probably survives four years or less.

To be most effective, sanitation treatments need to be thorough and based upon a prioritization of treatment areas. Much depends on the quality and completeness of the job. In any sanitation project, the actual treatment should be conducted with the utmost care to avoid the possibility of spreading the pathogen via the operation itself. Precautions such as timing treatments in the dry period of the year, treating uninfested areas first, keeping equipment clean, and not allowing vehicles used in the operation to travel from infested to uninfested areas without washing, can be standard. The importance of continued monitoring to determine if or when treated areas need retreatment cannot be over emphasized.

Girdling, cutting, pulling, or burning may kill Port-Orford-cedar. Ideally, if roadside sanitation is applied, all Port-Orford-cedars of any size adjacent to the road are treated. The general buffer width recommendation is 25 feet above the road or to the top of the cutbank. Below the road, suggested treatment width is 25 to 50 feet with greater distances where streams or drainages cross the road or where amount of road fill is particularly substantial, resulting in especially steep slopes. Local conditions may make recommendations outside of this general range appropriate.

Sanitation treatments need to be repeated periodically to maintain roadside buffers free of Port-Orford-cedar regeneration. The preferred approach is to monitor treated areas and re-treat them whenever Port-Orford-cedar seedlings 6 inches or taller are detected. The early establishment of other plants that out compete Port-Orford-cedar may also minimize roadside Port-Orford-cedar re-invasion.

Where a road runs through an uninfested area with Port-Orford-cedar, elimination of live cedar roots in a buffer along the roadside results in no live hosts close to spots where contaminated soil is most likely to fall off vehicles using the road. Zoospores, the propagules of $P$. lateralis that would most likely be spread away from a road, are delicate and vulnerable to desiccation. They are unlikely to reach and infect hosts beyond the buffer created in a sanitation treatment. Other spore types (chlamydospores or encysted zoospores) also have a greatly reduced probability of crossing a sanitation buffer. Roadside sanitation has been widely suggested for use in Port-Orford-cedar root disease management (Erwin and Ribeiro 1996, Goheen et al. 1997, Goheen et al. 1999, Hadfield et al. 1986, Hansen 1993, Hansen and Hamm 1996, Hansen and Lewis 1997, Hansen et al. 1999, Harvey et al. 1985, Kliejunas 1994, Nielsen 1997, Thies and Goheen in press, Zobel et al. 1985).

Some sectors of the public find sanitation treatments unpalatable because they entail removal of live individual Port-Orford-cedar to protect the population. There are also objections to the name "sanitation." Many believe that "sanitation" implies only removal of dead trees. 
There is also concern about the effectiveness of sanitation treatments. Starting in 1997, the Southwest Oregon Forest Insect and Disease Service Center initiated an investigation to obtain more quantitative data to evaluate the effectiveness of roadside sanitation treatments. Preliminary results indicate significant decreases in inoculum three to four years following treatments of already infested road sections (see following case studies).

Some federally-administered lands are interspersed with private lands. Frequently, road traffic cannot be legally restricted and if sanitation is not done across property boundaries, the sanitation treatment becomes fragmented. Overall effectiveness can be reduced if non-federal lands remain untreated.

Sanitation treatments may also be valuable in other areas besides roadsides; for example, treatments in infested riparian zones or in infestation centers not associated with roads and streams where: 1) the infested area is limited and discrete; 2) the mechanism of spread in the area is understood and lends itself to treatment; and 3) significant populations of uninfected Port-Orford-cedar are at risk in proximity to the infested area.

\section{Vehicle and Equipment Washing}

If the manager selects this technique, vehicles and equipment are thoroughly cleaned to remove adhering soil or plant debris that may contain $P$. lateralis before moving them into uninfested areas (fig. 10.7) and conversely, washing them before leaving infested areas of the forest (figs. 10.8 and 10.9).

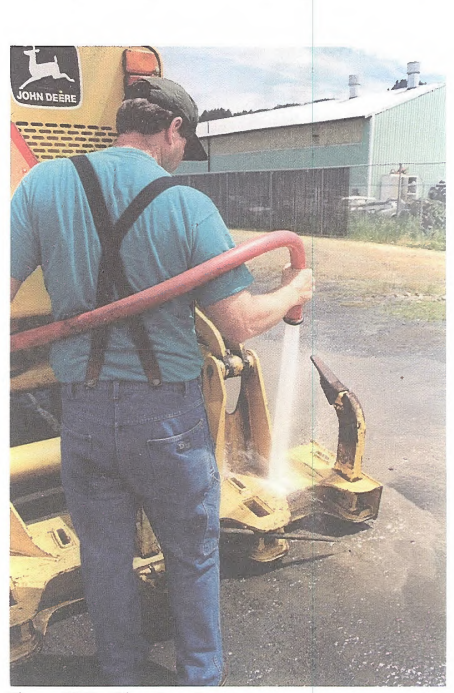

Figure 10.7-Cleaning rippers 


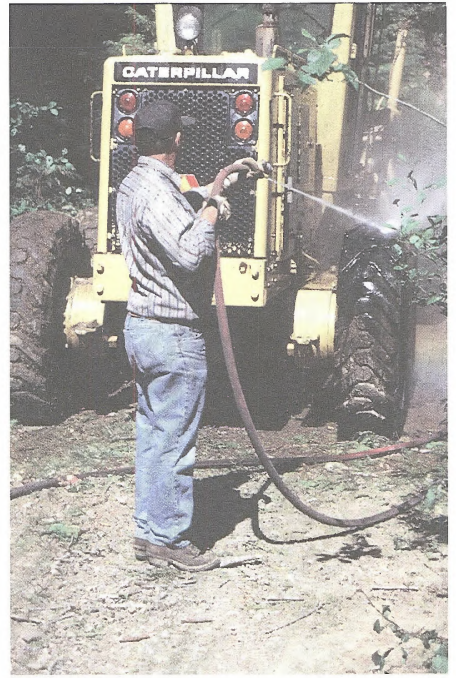

Figure 10.8-Washing equipment to remove soil potentially infested with Phytophthora lateralis

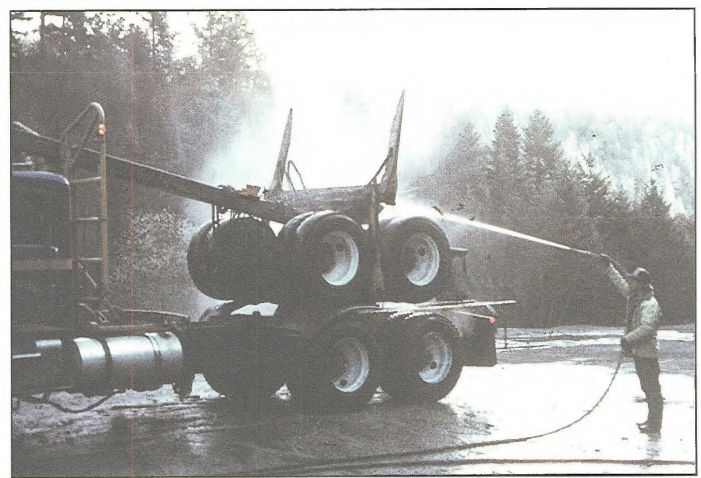

Figure 10.9-Washing a log truck to remove soil potentially infested with Phytophthora lateralis 
Vehicles that carry soil infested by $P$. lateralis are known to be by far the most important long-distance carriers of the pathogen. Vehicle washing has been widely suggested and used as a disease management technique (Betlejewski 1994, Goheen et al. 1997, Goheen et al. 1999, Hadfield et al. 1986, Hansen and Hamm 1996, Hansen and Lewis 1997, Hansen et al. 1999, Harvey et al. 1985, Jimerson 1994, Kliejunas 1994, Kliejunas and Adams 1980, Roth et al. 1987, Thies and Goheen in press, Zobel et al. 1985).

Location and design of washing stations are extremely important considerations. To reduce the potential for spread of $P$. lateralis, the following practices may be implemented:

- Locate washing stations as close as possible to infested sites. Ideally, vehicles would not travel for any substantial distance prior to being washed. Vehicles moving into uninfested areas may be washed miles away as long as they do not travel through infested areas to reach their destination.

- Locate washing stations in areas where run-off water has no chance of entering adjacent streams or drainages, or of threatening nearby cedars.

- Design washing stations so that vehicles that have been washed are not likely to be recontaminated by passing through wash water that contains $P$. lateralis propagules on their way out of the station.

An evaluation to test the effectiveness of a vehicle washing treatment was conducted by the Southwest Oregon Forest Insect and Disease Service Center in June, 1999. This study, summarized later in this chapter, used Port-Orford-cedar as bait trees to test the effectiveness of a vehicle washing treatment following exposure to $P$. lateralis. Results indicated that there were large reductions in inoculum on the vehicles following washing.

A major problem with vehicle washing as a Port-Orford-cedar root disease management technique is the difficulty of applying it consistently to all vehicles. Managers have a degree of control over vehicles used in projects and can require vehicle washing in the project contract, but many other vehicles are outside of their control and may or may not be cleaned. Efforts are underway to encourage a variety of forest users to voluntarily clean their vehicles, both through education to convince drivers that vehicle cleaning is worthwhile and through access to agency sponsored or supported washing stations (fig. 10.10).

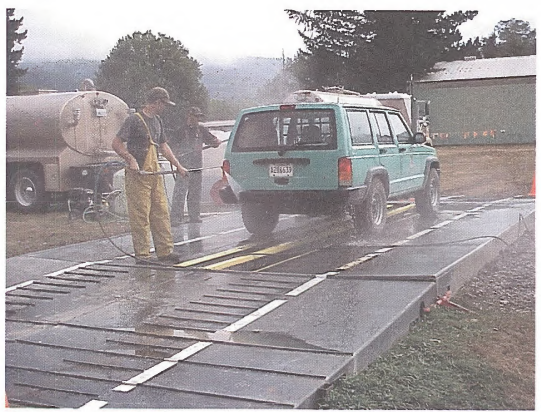

Figure 10.10-Vehicle washing station 


\section{Case Studies}

\section{Effectiveness Monitoring of Port-Orford-Cedar Roadside Sanitation Treatments in Southwest Oregon}

(Marshall and Goheen 2000)

In 1997, the Southwest Oregon Forest Insect and Disease Service Center began monitoring four sites with a systematic sampling procedure using small, tubed PortOrford-cedar seedlings as baits. The baits were out-planted in ten transects along a 0.25 to 0.50 mile segment of road at each site. Transects were located where introduction or movement of inoculum was likely (existing dead Port-Orford-cedar, stream crossings, swampy areas, pullouts, etc) and also at random points along the road. The baits were removed from the tubes and planted perpendicular to the road, on both sides of the road, beginning at the edge of the road and then periodically along the transect and into the adjacent stand beyond the boundary of the sanitized area. They were also planted in the roadside ditches above and below the intersection with each transect. At stream crossings with water present, seedlings were left in their tubes and secured in the channel with metal stakes. The locations of the baits were mapped so the transects could be resampled in subsequent years. Throughout the process, precautions were taken to avoid contamination such as scrubbing boots and planting tools in chlorinated water before planting each new seedling. Baits were left in the streams for two weeks, then retrieved and incubated in the tubes for four weeks. Planted baits were left on the site for six weeks and then all baits were examined for evidence of infection by $P$. lateralis.

As of 2001, 13 different sites have been monitored annually (including the original four). Two sites are infested but had not been sanitized, one was sanitized but is not infested and the other ten are infested and have been sanitized. Once transects are installed, the procedure is repeated with the baits in the same locations at approximately the same time each year. The intent is to monitor each site for at least 10 years.

Preliminary Results and Conclusions-There has been an overall decrease in the number of infected bait trees beginning in the third year after the sanitation treatment. Prior to treatment (year zero), an average of 24 percent of bait trees were infected. Five years after treatment, an average of 6 percent of bait trees were infected. In three years of monitoring at the infested site that has not been treated, the level of infection in the bait trees has remained between 14 and 22 percent. It is believed that the reduction of inoculum observed in areas that were infested prior to sanitation treatment suggests that treatments in such areas are indeed worthwhile.

Within transects, the location of infected baits has varied greatly from year to year. Location of viable inoculum is probably affected by the highly variable weather conditions during the spring in southwest Oregon. This affects soil moisture and temperature and the amount and temperature of water in streams and ditches, all factors that would affect the activity of the pathogen. In general, we have found the greatest number of infected baits in the roadside ditches. This suggests that these ditches function as traps for infested water. It means that design and maintenance of the ditches is an important component of managing roads to limit the spread of $P$. lateralis. Relatively few infected baits have been found near the outer edges of the sanitized areas.

In general, fewer infected bait trees were retrieved from streams than expected. Putting the seedlings in the stream with the tubes still in place may make it more difficult for infection to occur, or the high velocity of the water in many of the streams may make it unlikely for infection to occur during the short duration of the trial. 
One shortcoming of this procedure so far is the difficulty and uncertainty of monitoring success of sanitation treatments in uninfested areas. The baiting technique is only accurate for identifying the positive presence of $P$. lateralis. This technique will not necessarily predict the absence of $P$. lateralis if the baits were not located in the right places to intercept the pathogen.

\section{Effectiveness of Vehicle Washing in Decreasing Transport of P. lateralis Inoculum. \\ (Goheen et al. 2000)}

An evaluation to test the effectiveness of washing treatments was conducted by the Southwest Oregon Forest Insect and Disease Service Center on the Grants Pass Resource Area, Medford District, BLM, in early June, 1999. This study used a sample-based approach, using Port-Orford-cedar as bait trees to test the effectiveness of vehicle washing following exposure to $P$. lateralis inoculum in soil.

A muddy roadside in an area known to be infested with $P$. lateralis was selected as an exposure site. Two vehicles, a road grader and a pickup truck, and a pair of high top rubber boots were intentionally exposed to the mud in the infested area by driving or walking through the site. Following the exposure, the vehicles and the rubber boots were washed separately at two staged wash sites; the first wash site was 50 feet up the road from the exposure site, and the second was located 100 feet up the road from the first wash site. The length and intensity of each wash was comparable to operational washing treatments currently being used in Port-Orford-cedar root disease prevention projects. Samples of the wash water from the first and second wash were collected by placing ten gallon plastic tubs below the test vehicles and boots; one tub was partially filled with water directly from the tank to act as a control. Water from the second wash was collected in the same locations relative to the vehicles and the boots as with the first wash. The wash samples were transported to an incubation facility in Central Point where one-year-old Port-Orford-cedar seedlings were used as bait trees to test for the presence of inoculum in the various samples of wash water ( 20 seedlings per wash sample). After eight weeks, the seedlings were removed and examined for evidence of infection by $P$. lateralis. The seedlings exposed to water from the first wash of the boots averaged 65 percent infection while those exposed to water from the second wash showed 2.5 percent; seedlings exposed to water from the first wash of the pickup truck averaged 41.2 percent infection while those exposed to water from the second wash exhibited 3.7 percent; and seedlings exposed to water from the first wash of the road grader averaged 27.8 percent infection while those exposed to water from the second wash showed 2.2 percent infection.

This case study showed that an operational-type washing affected the amount of $P$. lateralis inoculum on vehicles and boots that were purposely exposed to infested soil. Although the inoculum was not completely eliminated, it was greatly reduced as a result of the first wash. It is possible that in moving from the first wash site to the second, the vehicle tires and rubber boots picked up additional inoculum left on the roadway by other vehicles passing through the infested area. The results also suggest that some places on the vehicles, such as the blade of the grader and the under side of the pickup truck, may be more difficult to clean completely with the type of washing treatments currently in use. Results of this case study support the use of vehicle washing as one treatment for reducing the probability of spreading $P$. lateralis from infested to uninfested areas. However, washing by itself should not be considered a completely effective 
treatment. Vehicle washing may be considered for use in combination with other treatments in an integrated Port-Orford-cedar root disease management strategy. The following recommendations were included:

- Locate and design vehicle washing stations to reduce the likelihood of vehicles being re-contaminated by passing through wash water containing $P$. lateralis, and where there is no chance of runoff water entering adjacent streams, drainages, or uninfested concentrations of Port-Orford-cedar. Washing stations should be located in welldrained areas where vehicles can be washed over rocks or gravel; wash ramps could also provide a good area for washing vehicles.

- When possible, use the most effective and techniques for cleaning hard to reach areas.

- A stiff bristle brush should be carried in each vehicle for cleaning boots. Footwear should be brushed vigorously to remove obvious adhering soil and mud before entering the vehicle to travel to a new location (fig. 10.11), especially when leaving an area with obvious current disease-caused Port-Orford-cedar mortality.

\section{Managing Port-Orford-Cedar in Areas Not Favorable to the Pathogen.}

In spite of the virulence of $P$. lateralis, and the fact that it has spread widely along roads and streams through a good portion of Port-Orford-cedar's range, there are still considerable numbers of sites, many of them substantial in size, where naturally occurring Port-Orford-cedar are thriving. Cedar on such sites has escaped infection because the sites have characteristics that are unfavorable for spread of the pathogen.

Port-Orford-cedar can be preferentially managed on sites where conditions make it likely they will escape infection by $P$. lateralis, even if the pathogen has already been established

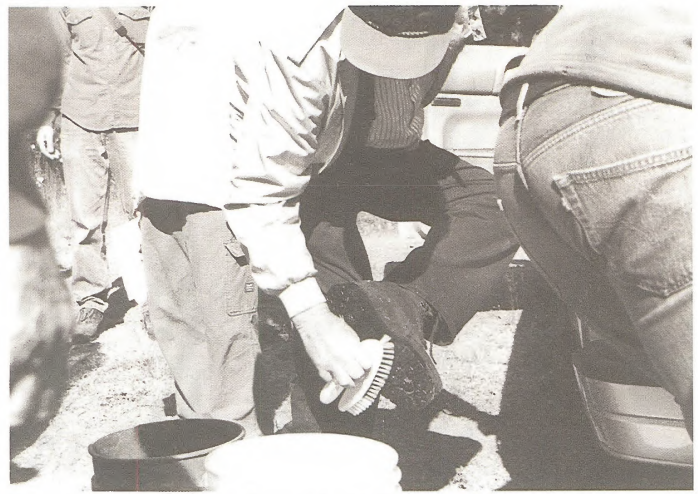

Figure 10.11-Boots are cleaned to avoid spreading Phytophthora lateralis 
nearby or may be introduced in the future. Port-Orford-cedar on low-risk sites-above and away from roads, uphill from creeks, on ridgetops, and well-drained locales- are likely to survive.

Maintaining existing Port-Orford-cedar on low vulnerability sites such as convex slopes and ridge tops above roads has been commonly suggested as a disease management technique; actually developing "cedar production areas" by planting and actively managing Port-Orford-cedar on sites with such characteristics has also been suggested (Goheen et al. 1997, Goheen et al. 1999, Hadfield et al. 1986, Harvey et al. 1985, Hansen et al. 1999, Koepsell and Pscheidt 1994, Nielsen 1997, Roth et al. 1987, Thies and Goheen in press, USDA 1983, Zobel et al. 1985).

Maintaining natural Port-Orford-cedar on low risk sites has not been well evaluated, but field observation strongly indicates its success. P. lateralis is clearly capable of killing most, if not all, Port-Orford-cedar that it infects, so the widespread occurrence of healthy hosts throughout the cedar's range is a testimonial to the fact that naturally occurring trees on many kinds of sites do, indeed, escape infection.

\section{Managing Port-Orford-Cedar in Areas Favorable to the Pathogen}

Within infested sites that have characteristics particularly favorable for $P$. lateralis spread, observations show that some Port-Orford-cedar escape infection because of the microsites where they occur. Even what appear to be very slight microsite differences (elevated areas of only a few feet) can greatly influence the likelihood of infection. Spread of the pathogen from tree to tree, particularly around the margins of infestation centers or areas where overland flow of water is somewhat channeled, is also influenced by the spacing of Port-Orford-cedar and location of individual trees. Some spread is known to occur via root grafts between cedars; grafting potential has been shown to decrease substantially when Port-Orford-cedar are 18 feet or more apart on flat ground and five feet or more apart vertically on steeply sloping ground (Gordon 1974, Gordon and Roth 1976).

Distances between trees may also influence spread of $P$. lateralis via zoospores in water. Zoospores are quite delicate and can swim only short distances (1.2 to 2.4 inches) in standing water though they can be carried considerable distances in moving water (Carlile 1983, Hansen and Lewis 1997). If trees are outside of drainage channels and are widely spaced, they may escape infection. Wide-spacing and consideration of microsites in determining where to plant or maintain natural Port-Orford-cedar has been suggested (Hadfield et al. 1986, Harvey et al. 1985, Roth et al. 1987).

Port-Orford-cedar can be favored in plantings and thinnings on microsites that are unfavorable for the pathogen within infested areas (especially mounds and other high places) or, conversely, not favored on microsites optimal for infestation (close to and below roads, in or very close to streams or drainage ditches, and in low lying wet areas). Port-Orford-cedar may be planted or retained in thinnings in mixed species stands at wide spacing ( 25 feet or more between individual trees) (Harvey et al. 1985, Hadfield et al. 1986). 


\section{Manipulating Species Composition}

Favoring tree species other than Port-Orford-cedar that are appropriate for local sites is especially applicable where $P$. lateralis is already established or in sites that are particularly favorable for future establishment of the pathogen.

P. lateralis is host-specific and most tree species that grow within the range of PortOrford-cedar do not become infected (Zobel et al. 1985). Only Port-Orford-cedar and occasionally Pacific yew (Taxus brevifolia) are infected by P. lateralis under natural conditions (DeNitto and Kliejunas 1991, Erwin and Ribeiro 1996, Hepting, 1971, Murray and Hansen 1997, USDA 1992). Planting alternate species has been suggested (Filip et al. 1995, USDA 1983) and has been done in some areas that have been severely impacted by P. lateralis.

\section{Management Challenges}

Some particularly formidable challenges associated with Port-Orford-cedar root disease management on federal lands are listed below.

\section{Difficulty of Monitoring Effectiveness of Management Activities}

Effectiveness monitoring of Port-Orford-cedar root disease management activities is extremely difficult. Frequently, monitoring has been subjective. A treatment may have been rated as fully effective, partially effective or not effective. This type of monitoring is not especially useful; it is not quantitative and cannot be statistically analyzed. What constitutes an "effective" treatment has not been standardized. Ideally, effectiveness is based on lack of new infections in an area, but in some cases it may be based on whether or not the treatment was installed effectively, i.e., a gate remains free of vandalism or all Port-Orford-cedar are indeed removed in a sanitation treatment. Optimally, to evaluate treatment effectiveness, sample-based monitoring that determines $P$. lateralis presence and abundance on a site after the treatment, is required.

In spite of past research efforts, no accurate, inexpensive, and quick soil assay technique for $P$. lateralis has been devised that can be used easily in the field. Baiting, using PortOrford-cedar seedlings as described in the Southwest Oregon Forest Insect and Disease Service Center's road sanitation monitoring effort, is the best technique currently available (Goheen and Marshall, in press). It is fairly inexpensive and accurate, but takes up to two months to provide results. It can be installed with a design that lends itself to statistical analyses.

\section{Few Opportunities to Obtain New Management-Related Research Results}

Although public and federal agency interest is great, and opportunities for investigating new management techniques or using research to test effectiveness of established techniques abound, there are few researchers working on Port-Orford-cedar root disease or on management related questions. Funding for research on Port-Orford-cedar and $P$. lateralis is essential for the success of the programs. 


\section{Public Opposition to Agency Management Activities}

Federal agencies have found that keeping all sectors of the public informed and, when possible, supportive of the agencies' Port-Orford-cedar root disease management is an important but difficult task. Environmental groups were instrumental in developing awareness of the seriousness of the disease and the importance of managing it. But some of these same groups actively oppose agency management because they do not believe the techniques being employed will be effective. Some believe that only exclusion or permanent road closures are worthwhile strategies.

\section{Coordination Difficulties}

Although coordination has improved in recent years among public land management agencies, each agency has different regulations, management agendas, emphasis areas, and administrative rules. A challenge is associated with trying to coordinate activities with private landowners. Many landowners do not cooperate because maintaining PortOrford-cedar is not an important objective for them, because they are worried about the costs, delays, and inconveniences associated with such management efforts, or because they fear that cooperation may lead to future regulations that would impact their abilities to manage their own lands as they see fit. Such lack of cooperation can severely decrease the effectiveness of federal Port-Orford-cedar management or limit its success to only parts of a landscape.

\section{Funding Uncertainties}

Many Port-Orford-cedar root disease management and research activities are expensive. Both the Forest Service and the BLM have maintained funding for root disease management efforts on federal lands at a reasonably high level for the past few years. Funding for research, however, has been more difficult to obtain. A considerable proportion of root disease management support for both agencies has come from national Forest Health Protection funds (U.S. Department of Agriculture). To qualify for such funding, local managers must apply annually and compete against other proposed disease management projects from throughout the country. Agency managers are concerned about the dependability of future Port-Orford-cedar root disease management and research funding. 
Betlejewski, F. 1994. Port-Orford-cedar management guidelines. Portland, OR: U.S. Department of the Interior, Bureau of Land Management. 32 p.

Carlile, M.J. 1983. Motility, taxis, and tropism in Phytophthora. In: Erwin, D.C.; BartnickiGarcia, S.; Tsao, P.H., eds. Phytophthora: its biology, taxonomy, ecology, and pathology. St. Paul, MN: American Phytopathological Society: 95-107.

Daniel, T.W.; Helms, J.A.; Baker, F.S. 1979. Principles of silviculture. New York: McGrawHill. 500 p.

DeNitto, G. 1992. Phytophthora lateralis eradication-Camp Six, Gasquet Ranger District. Redding, CA: U.S. Department of Agriculture, Forest Service, Forest Health Protection, Northern California Shared Service Area, 2400 Washington Avenue, Redding, CA 96001. Administrative report. 3 p. On file with: Southwest Oregon Forest Insect and Disease Service Center, J. Herbert Stone Nursery, 2606, Old Stage Road, Central Point, OR 97502.

DeNitto, G.; Kliejunas, J.T. 1991. First report of Phytophthora lateralis on pacific yew [Abstract]. Plant Disease 75:968.

Erwin, D.C.; Ribeiro, O.K. 1996. Phytophthora diseases worldwide. Saint Paul, MN: American Phytopathological Society. 562 p.

Filip, G.M.; Kanaskie, A.; Campbell III, A. 1995. Forest disease ecology and management in Oregon. Corvallis, OR: Oregon State University Extension Service. 60 p.

Goheen, D.J.; Marshall, K. In press. Monitoring effectiveness of roadside sanitation treatments to decrease likelihood of spread of Phytophthora lateralis in southwest Oregon. Proceedings of the second international meeting on Phytophthoras in forest and wildland ecosystems, IUFRO working party 7.02.09. Perth, Western Australia: Murdoch University.

Goheen, D.J.; Marshall, K.; Hansen, E.M.; Betlejewski, F. 2000. Effectiveness of vehicle washing in decreasing Phytophthora lateralis inoculum: a case study. SWOFIDSC-00-2. Central Point, OR: U.S. Department of Agriculture, Forest Service, Southwest Oregon Insect and Disease Service Center. 7 p.

Goheen, D.J.; Marshall, K.; Hansen, E.M.; DeNitto, G.A. 1997. Port-Orford-cedar root disease: ecological implications and management. In Beigel, J.K.; Jules, E.S.; Snitkin, B., eds. Proceedings of the first conference on Siskiyou ecology. Cave Junction, OR: Siskiyou Regional Educational Project: 189.

Gordon, D.E. 1974. The importance of root grafting in the spread of Phytophthora root rot in an immature stand of Port-Orford-cedar. Corvallis OR: Oregon State University; 116 p. M.S. thesis.

Gordon, D.E.; Roth, L.F. 1976. Root grafting in Port-Orford-cedar : an infection route for root rot. Forest Science 22:276-278.

Hadfield, J.S.; Goheen, D.J.; Filip, G.M.; Schmitt, C.L.; Harvey, R.D. 1986. Root diseases in Oregon and Washington conifers. R6-FPM-250-86. Portland, OR: U.S. Department of Agriculture, Forest Service, Pacific Northwest Region. 27 p. 
Hansen, E.M. 1993. Roadside surveys for Port-Orford-cedar root disease on the Powers Ranger District, Siskiyou National Forest. Unpublished report. 17p. On file with: Southwest Oregon Forest Insect and Disease Service Center, J. Herbert Stone Nursery, 2606, Old Stage Road, Central Point, OR 97502.

Hansen, E.M.; Goheen, D.J.; Jules, E.S.; Ullian, B. 1999. Managing Port-Orford-cedar and the introduced pathogen Phytophthora lateralis. Plant Disease 84:4-14.

Hansen, E.M.; Hamm, P.B. 1996. Survival of Phytophthora lateralis in infected roots of PortOrford-cedar. Plant Disease 80:1075-1078.

Hansen, E.M.; Hamm, P.B.; Roth, L.F. 1989. Testing Port-Orford-cedar for resistance to Phytophthora. Plant Disease 73(10):791-794.

Hansen, E.M.; Lewis, K.J. 1997. Compendium of conifer diseases. St. Paul, MN: American Phytopathological Society. $101 \mathrm{p}$.

Harvey, R.D.; Hadfield, J.H.; Greenup, M. 1985. Port-Orford-cedar root rot on the Siskiyou National Forest in Oregon. Portland, OR: U.S. Department of Agriculture, Forest Service, Pacific Northwest Region. Administrative report. 17 p. On file with: Southwest Oregon Forest Insect and Disease Service Center, J. Herbert Stone Nursery, 2606, Old Stage Road, Central Point, OR 97502.

Hepting, G.H. 1971. Diseases of forest and shade trees of the United States. Agriculture Handbook No. 386. Washington, D.C.: U. S. Department of Agriculture, Forest Service. $658 \mathrm{p}$.

Jimerson, T.M. 1994. A field guide to Port-Orford-cedar plant associations in northwest California. R5-ECOL-TP-002. Eureka, CA: U.S. Department of Agriculture Forest Service, Pacific Southwest Region, Six Rivers National Forest. 109 p.

Kliejunas, J.T. 1994. Port-Orford-cedar root disease. Fremontia 22:3-11.

Kliejunas, J.T.; Adams, D.H. 1980. An evaluation of Phytophthora root rot of Port-Orfordcedar in California. Forest Pest Management Report No. 80-1. San Francisco, CA: U.S. Department of Agriculture, Forest Service, Region 5.16 p.

Koepsell, P.A.; Pscheidt, J.W. 1994. Pacific northwest plant disease control handbook. Corvallis, OR: Oregon State University. 349 p.

Marshall, K.; Goheen, D.J. 2000. Preliminary results of effectiveness monitoring of PortOrford-cedar roadside sanitation treatments in southwest Oregon. In: Hansen and Sutton, eds. Proceedings of the first international meeting on Phytophthoras in forest and wildland ecosystems, IUFRO working party 7.02.09. Corvallis, OR: Oregon State University, Forest Research Laboratory: 125-126.

Murray, M.S.; Hansen, E.M. 1997. Susceptibility of pacific yew to Phytophthora lateralis. Plant Disease 81:1400-1404.

Murray, M.S.; McWilliams, M.; Hansen, E.M. 1995. Survival of Phytophthora lateralis in chlorine bleach. Unpublished report. 8 p. On file with: Oregon State University, Department of Botany and Plant Pathology, Corvallis, OR.

Nielsen, J. 1997. Port-Orford-cedar: a reasonable risk for reforestation (under specific conditions). Northwest Woodlands 13:22-23. 
Ostrofsky, W.D.; Pratt, R.G.; Roth, L.F. 1977. Detection of Phytophthora lateralis in soil organic matter and factors that affect its survival. Phytopathology 67:79-84.

Roth, L.F.; Bynum, H.H.; Nelson, E.E. 1972. Phytophthora root rot of Port-Orford-cedar. Forest Pest Leaflet 131. Portland, OR: U.S. Department of Agriculture, Forest Service, Pacific Northwest Forest and Range Experiment Station. 7 p.

Roth, L.E.; Harvey, R.D. Jr.; Kliejunas, J.T. 1987. Port-Orford-cedar root disease. Forest Pest Management Report No. R6 FPM-PR-294-87. Portland, OR: U.S. Department of Agriculture, Forest Service, Region 6. 11 p.

Scharpf, R.F., tech. coord. 1993. Diseases of pacific coast conifers. Agriculture Handbook 521. Albany, CA: U.S. Department of Agriculture, Forest Service, Pacific Forest Research Station. 199 p.

Smith, D.M. 1962. The practice of silviculture. $9^{\text {th }}$ edition. New York, NY: John Wiley and Sons, Inc. $578 \mathrm{p}$.

Tainter, F.H.; Baker, F.A. 1996. Principals of forest pathology. New York, NY: John Wiley and Sons, Inc. 805 p.

Thies, W.G.; Goheen, E.M. In press. Major forest diseases of the Oregon Coast Range and their management. Summary of the COPE [Coastal Oregon Productivity Enhancement Program] Project.

Trione, E.J. 1959. The pathology of Phytophthora lateralis on native Chamaecyparis lawsoniana. Contributions to the Boyce Thompson Institute 17:359-373.

Trione, E.J. 1974. Sporulation and germination of Phytophthora lateralis. Phytopathology 64:1531-1533.

Tucker, C.M.; Milbrath, J.A. 1942. Root rot of Chamaecyparis caused by a species of Phytophthora. Mycologia. 34:94-103.

Umaerus, V.; Umareus, M; Erjefalt, L.; Nilsson, B.A. 1983. Control of Phytophthora by host resistance: problems and progress. In Erwin, D.C.; Bartnicki-Garcia, S; Tsao, P.H., eds. Phytophthora: its biology, taxonomy, ecology, and pathology. St. Paul, MN: American Phytopathological Society: 315-326.

U.S. Department of Agriculture, Forest Service. 1983. Forest disease management notes. GPO 1983 695-726. Portland, OR: Pacific Northwest Region. 52 p.

U.S. Department of Agriculture, Forest Service. 1992. An interim guide to the conservation and management of Pacific yew. Portland, OR: Pacific Northwest Region. 72 p.

Zobel, D.B. 1990. Chamaecyparis lawsoniana (A. Murr.) Parl., Port-Orford-cedar. In: Burns, R.M.; Honkala, B.H., tech. coords. Silvics of North America: conifers. Agricultural handbook 654. Washington, DC: U.S. Department of Agriculture Forest Service. Vol. 1.

Zobel, D.B.; Roth, L.F.; Hawk, G.M. 1985. Ecology, pathology, and management of PortOrford-cedar (Chamaecyparis lawsoniana). General Technical Report PNW-184. Portland, OR: U.S. Department of Agriculture, Forest Service Pacific Northwest Forest and Range Experiment Station. 161 p. 


\section{Appendix A}

\section{The Relationship of the Port-Orford-Cedar Range-wide Assessment to Other Legal Documents and Authorities}

June 2001

Other than an appendix reference the Northwest Forest Plan does not specifically address Port-Orford-cedar or the root disease caused by Phytophthora lateralis, but it does place emphasis on maintenance of riparian habitat and sustaining ecological viability of all native species.

Existing Forest Service and Bureau of Land Management (BLM) Plans within the range of Port-Orford-cedar recommend management actions that reduce the spread and severity of the root disease, maintain Port-Orford-cedar as a component of appropriate forest ecosystems, and incorporate analysis of effects to Port-Orford-cedar into environmental analyses and project planning (USDA 1989, 1990, 1995a, b, c; USDI 1995a, b, c).

The Secretary of Agriculture, through the Forest Service, is authorized "to assist in ... the prevention and control of insects and diseases affecting trees and forests" on nonfederal lands (USC, Title 16, Chapter 41, Sec. 2101). The Cooperative Forestry Assistance Act of 1978, as amended, authorizes the Forest Service to provide technical and financial assistance on forest lands administered by other federal agencies, tribal lands, and on State and private forest lands.

This document does not contain a comprehensive analysis of Port-Orford-cedar on all ownerships within the range of Port-Orford-cedar and does not make any blanket recommendations for all lands within the range of Port-Orford-cedar. It provides tools and information for any landowner who manages Port-Orford-cedar as a component of their forest.

This assessment is closely tied to other ongoing and proposed analyses. These include watershed analyses, late-successional reserve assessments, transportation management plans, the BLM's Plant Genetics Plan, analyses of Forest Service road networks, and offhighway vehicle strategies.

National emphasis on managing and reducing the impacts on native ecosystems from non-native organisms is increasing. In 1996, a National Invasive Species Act was passed, which targeted non-native species for control measures. The National Invasive Species Council was established in 1999 to oversee management and prevention programs for control of invasive species. P. lateralis is an invasive species. It is probably not native to North America and certainly not native to the natural range of Port-Orford-cedar. 


\section{Literature Cited}

U.S. Department of Agriculture, Forest Service. 1989. Siskiyou National Forest land and resource management plan. Portland, OR.

U.S. Department of Agriculture, Forest Service. 1990. Siuslaw National Forest land and resource management plan. Portland, OR.

U.S. Department of Agriculture, Forest Service. 1995a. Land and resource management plan, Klamath National Forest. Yreka, CA.

U.S. Department of Agriculture, Forest Service. 1995b Land and resource management plan, Six Rivers National Forest. Eureka, CA.

U.S. Department of Agriculture, Forest Service. 1995c. Shasta-Trinity National Forest land and resource management plan. Vallejo, $\mathrm{CA}$.

U.S. Department of the Interior, Bureau of Land Management. 1995a. Coos Bay District record of decision and resource management plan. North Bend, OR.

U.S. Department of the Interior, Bureau of Land Management. 1995b. Record of decision and resource management plan, Medford District. Medford, OR.

U.S. Department of the Interior, Bureau of Land Management. 1995c. Record of decision and resource management plan, Roseburg District. Roseburg, OR. 


\section{Appendix B}

Occurrence of Plant Associations with PortOrford-Cedar by Ecoregion or Subsection 


\begin{tabular}{|c|c|c|c|c|c|c|c|c|c|c|c|c|c|}
\hline & \multicolumn{13}{|c|}{ Ecoregion or Subsection } \\
\hline & $\begin{array}{c}\text { Mid-coastal } \\
\text { Sedimentary } \\
\text { and Southern } \\
\text { Oregon } \\
\text { Coastal }\end{array}$ & $\begin{array}{c}\text { Coastal } \\
\text { Siskiyous }\end{array}$ & $\begin{array}{c}\text { Eastern } \\
\text { Franciscan }\end{array}$ & $\begin{array}{c}\text { Gasquet } \\
\text { Mountain } \\
\text { Ultramafics }\end{array}$ & $\begin{array}{l}\text { Serpentine } \\
\text { Siskiyous }\end{array}$ & $\begin{array}{l}\text { Western } \\
\text { Jurassic }\end{array}$ & $\begin{array}{l}\text { Siskiyou } \\
\text { Mountains }\end{array}$ & $\begin{array}{c}\text { Inland } \\
\text { Siskiyous }\end{array}$ & $\begin{array}{l}\text { Pelletreau } \\
\text { Ridge }\end{array}$ & $\begin{array}{c}\text { Rattlesnake } \\
\text { Creek }\end{array}$ & $\begin{array}{c}\text { Eastem } \\
\text { Klamath } \\
\text { Mountains }\end{array}$ & $\begin{array}{l}\text { Lower Scott } \\
\text { Mountains }\end{array}$ & $\begin{array}{l}\text { Upper Scott } \\
\text { Mountains }\end{array}$ \\
\hline & & & & California & Oregon & & Califonnia & Oregon & & & & & \\
\hline Port-Orford-cedar/Hairy Honeysuckle/Fescue & & & & & & & & $\mathrm{x}$ & & & & & \\
\hline $\begin{array}{l}\begin{array}{l}\text { Port-Orford-cedar/Huckleberry Oak/ } \\
\text { Beargrass }\end{array} \\
\end{array}$ & & & & & & & & $x$ & & & & & \\
\hline $\begin{array}{l}\text { Port-Orford-cedar/Pacific Rhododendron- } \\
\text { Satlal }\end{array}$ & $x$ & $x$ & $x$ & $x$ & $x$ & $x$ & $x$ & $x$ & & & & & \\
\hline Fort-Orford-cedar/Salal & & & $x$ & $\mathrm{x}$ & & $x$ & $x$ & & & & & & \\
\hline Port-Orford-cedar/Western Azalea & & & $\mathrm{x}$ & $\mathrm{x}$ & & $\mathrm{x}$ & $\mathrm{x}$ & & $\mathrm{x}$ & & & & \\
\hline $\begin{array}{l}\begin{array}{l}\text { Port-Orford-cedar-Douglas fir/Califormia } \\
\text { hlazeinut }\end{array} \\
\end{array}$ & & & & & & & $x$ & & & & & & \\
\hline Port-Orford-cedar-Douglas-fir/Hazelnut//6-R & & & & & $x$ & & & & & & & & \\
\hline $\begin{array}{l}\text { Port-Orford-cedar-Douglas-fir/Huckleberry } \\
\text { Oak }\end{array}$ & & & $x$ & $\mathrm{x}$ & & $x$ & $\mathrm{x}$ & & $\mathrm{x}$ & & & & \\
\hline \begin{tabular}{|l} 
Port-Orford-cedar-Douglas-fir/Spicebush \\
\end{tabular} & & & & & & & & & & & $\mathrm{x}$ & $x$ & \\
\hline $\begin{array}{l}\text { Port-Offord-cedar-Douglas-fir-Alder/Vine } \\
\text { Maple-Oregon-grape }\end{array}$ & & & & & & & $x$ & & & & & & \\
\hline $\begin{array}{l}\text { Port-Orford-cedar/Evergreen Huckleberry/ } \\
\text { Western Swordfem }\end{array}$ & $x$ & & & & & & & & & & & & \\
\hline Fort-Orford-cedar-Incense Cedar-Alder & & & & $x$ & & $x$ & $\mathrm{x}$ & & & & & & \\
\hline $\begin{array}{l}\text { Port-Orford-cedar - Mixed Conifer/ } \\
\text { Huckleberry Oak - Western Azalea }\end{array}$ & & & & & & & $x$ & & & & & $x$ & $x$ \\
\hline $\begin{array}{l}\text { Port-Orford-cedar-Mixed Conifer/Western } \\
\text { Azallea-Dwarf Tanbark }\end{array}$ & & & & & & & & & & & $x$ & $x$ & $x$ \\
\hline $\begin{array}{l}\begin{array}{l}\text { Port-Orford-cedar-Mountain Hemlock/Bush } \\
\text { Clinguapin }\end{array} \\
\end{array}$ & & & & & & & & & & & & & $\mathrm{x}$ \\
\hline $\begin{array}{l}\begin{array}{l}\text { Port-Orford-cedar-Mountain Hemlock/ } \\
\text { Labrador Tea }\end{array} \\
\end{array}$ & & & & & & & & & & & & & $\mathrm{x}$ \\
\hline $\begin{array}{l}\begin{array}{l}\text { Port-Orford-cedar-Mountain Hemlock/Sierra } \\
\text { Laurel }\end{array} \\
\end{array}$ & & & & & & & & & & & & & $\mathrm{x}$ \\
\hline $\begin{array}{l}\text { Port-Orfford-cedar-Red Fir/Sadler Oak- } \\
\text { Thinleaf Huckleberry }\end{array}$ & & & & $x$ & & & $x$ & & & & & & \\
\hline $\begin{array}{l}\text { Port-Orford-cedar-Red Fit/Sadler Oak- } \\
\text { Thinleaf Htuckleberry//R-6 }\end{array}$ & & & & & & & & $x$ & & & & & \\
\hline $\begin{array}{l}\begin{array}{l}\text { Port-Orford-cedar-Red Fir/Sitka Alder/ } \\
\text { california Pitcher Plant }\end{array} \\
\end{array}$ & & & & & & & $x$ & & & & & & \\
\hline $\begin{array}{l}\text { Port-Orford-cedar-Red Fir/Sitka Alder-Sadler } \\
\text { Oak }\end{array}$ & & & & & & & $x$ & & & & & & \\
\hline $\begin{array}{l}\text { Port-Orford-cedar-Red Fir-Brewer Spruce/ } \\
\text { Sadler Oak-Huckleberry Oak }\end{array}$ & & & & & & & $\mathrm{x}$ & & & & & & \\
\hline Port-Orford-cedar-Tanoak/Salal & & & & & $x$ & & & $\mathrm{x}$ & & & & & \\
\hline $\begin{array}{l}\begin{array}{l}\text { Port-Orford-cedar-White Fir/Dwarf Oregon- } \\
\text { grape }\end{array} \\
\text { - }\end{array}$ & & & & & & & & $\mathrm{x}$ & & & & & \\
\hline
\end{tabular}




\begin{tabular}{|c|c|c|c|c|c|c|c|c|c|c|c|c|c|}
\hline & \multicolumn{13}{|c|}{ Ecoregion or Subsection } \\
\hline & \begin{tabular}{|c|} 
Mid-coastal \\
Sedimentary \\
and Southern \\
Oregon \\
Coastal \\
\end{tabular} & $\begin{array}{c}\text { Coastal } \\
\text { Siskiyous }\end{array}$ & $\begin{array}{l}\text { Eastern } \\
\text { Franciscan }\end{array}$ & $\begin{array}{l}\text { Gasquet } \\
\text { Mountain } \\
\text { Ultramafics } \\
\end{array}$ & $\begin{array}{l}\text { Serpentine } \\
\text { Siskiyous }\end{array}$ & $\begin{array}{l}\text { Western } \\
\text { Jurassic }\end{array}$ & $\begin{array}{l}\text { Siskiyou } \\
\text { Mourtains }\end{array}$ & $\begin{array}{l}\text { Irland } \\
\text { Siskiyous }\end{array}$ & $\begin{array}{c}\text { Pelletreau } \\
\text { Ridge }\end{array}$ & $\begin{array}{c}\text { Rattlesnake } \\
\text { Creek }\end{array}$ & $\begin{array}{l}\text { Eastern } \\
\text { Klamath } \\
\text { Mountains }\end{array}$ & $\begin{array}{l}\text { Lower Scott } \\
\text { Mountains }\end{array}$ & $\begin{array}{l}\text { Upper Scott } \\
\text { Mountains }\end{array}$ \\
\hline & & & & California & Oregon & & California & Oregon & & & & & \\
\hline $\begin{array}{l}\text { Port-Orford-cedar-Western Hemlock/Sierra } \\
\text { Laurel }\end{array}$ & & & & & & & & $x$ & & & & & \\
\hline $\begin{array}{l}\text { Port-Orford-cedar-Western Hemlock/ } \\
\text { Swordfern }\end{array}$ & $X$ & & & & & & & & & & & & \\
\hline $\begin{array}{l}\text { Port-Orford-cedar-Westem White Pine//Dry } \\
\text { Herb Complex }\end{array}$ & & & & & & & & & & & & & $x$ \\
\hline $\begin{array}{l}\text { Port-Orford-cedar-Western White Pine/ } \\
\text { Huckleberry Oak } \\
\end{array}$ & & & $x$ & $x$ & & $x$ & $x$ & & $x$ & & & & \\
\hline $\begin{array}{l}\text { Port-Orford-cedar-Western White Pine/ } \\
\text { Labrador Tea/California Pitcher Plant }\end{array}$ & & & $x$ & $x$ & & & $x$ & & & & & & $x$ \\
\hline $\begin{array}{l}\text { Port-Orford-cedar-Western White Pine/ } \\
\text { Labrador Tea/California Pitcher Plant// } \\
\text { Coastal }\end{array}$ & & & & $x$ & & $x$ & $x$ & & & & & & \\
\hline $\begin{array}{l}\text { Port-Orford-cedar-Western White Pine/Sitka } \\
\text { Alder }\end{array}$ & & & & & & & & & & & & $x$ & $x$ \\
\hline $\begin{array}{l}\text { Port-Orford-cedar-Western White Pine/ } \\
\text { Thinleaf Huckleberry }\end{array}$ & & & & & & & & & & & & & $x$ \\
\hline $\begin{array}{l}\text { Port-Orford-cedar-Western White Pine/ } \\
\text { Western Azalea-Dwarf Tanbark-Labrador Tea }\end{array}$ & & & & $x$ & & $x$ & $x$ & & $x$ & & & & \\
\hline $\begin{array}{l}\text { Port-Orford-cedar-Western White Pine// Wet } \\
\text { Herb Complex }\end{array}$ & & & & & & & $x$ & & & & & & $x$ \\
\hline $\begin{array}{l}\text { Port-Orford-cedar-White Fir/Bush } \\
\text { Chinquapin-Western Azalea }\end{array}$ & & & & & & & & & & & & & $x$ \\
\hline $\begin{array}{l}\text { Port-Orford-cedar-White Fir/Dwarf Oregon- } \\
\text { grape }\end{array}$ & & & & & $x$ & & & & & & & & \\
\hline Port-Orford-cedar-White Fir //Herb & & & & $x$ & & & $x$ & & $x$ & & & & \\
\hline Port-Orford-cedar-White Fir/Huckleberry Oak & & & & $x$ & & & $\mathrm{x}$ & & $\mathrm{X}$ & & & & \\
\hline Port-Orford-cedar-While Fir/Sadler Oak & & & & $x$ & & & $\mathrm{x}$ & & & & & & \\
\hline $\begin{array}{l}\text { Port-Orford-cedar-White Fir/Sierra Laurel- } \\
\text { Bush Chinquapin }\end{array}$ & & & & & & & & & & & & & $\mathrm{x}$ \\
\hline Port-Orford-cedar-White Fir/Sitka Alder & & & & & & $x$ & $\mathrm{x}$ & & & & & & \\
\hline Port-Orford-cedar-White Fir/Vine Maple & & & & & & & $x$ & & & & & & \\
\hline Port-Orford-cedar-White Fir/Western Azalea & & & & $\mathrm{X}$ & & $x$ & $\mathrm{x}$ & & & & & & \\
\hline $\begin{array}{l}\text { Port-Orford-cedar-White Fir/Western Azaleà- } \\
\text { Huckleberry Oak }\end{array}$ & & & & & & & $x$ & & & & & $x$ & $x$ \\
\hline $\begin{array}{l}\text { Port-Orford-cedar-White Fir-Western White } \\
\text { Pine/Huckleberry Oak }\end{array}$ & & & & $x$ & & & $x$ & & & & & & \\
\hline Douglas-fir/Salal-Dwarf Oregont-grape & & $x$ & & & & & & & & & & & \\
\hline Douglas-fir/Salal-Pacific Rhododendron & $\mathrm{x}$ & $\mathrm{x}$ & & & $x$ & & & $\mathrm{x}$ & & & & & \\
\hline Douglas-fir/Salmonberry/Swordfern & & & & & & & & $x$ & & & & & \\
\hline
\end{tabular}




\begin{tabular}{|c|c|c|c|c|c|c|c|c|c|c|c|c|c|}
\hline & \multicolumn{13}{|c|}{ Ecoregion or Subsection } \\
\hline & $\begin{array}{c}\text { Mid-coastal } \\
\text { Sedimentary } \\
\text { and Southern } \\
\text { Oregon } \\
\text { Coastal }\end{array}$ & $\begin{array}{c}\text { Coastal } \\
\text { Siskiyous }\end{array}$ & $\begin{array}{c}\text { Eastern } \\
\text { Franciscan }\end{array}$ & $\begin{array}{l}\text { Casquet } \\
\text { Mountain } \\
\text { Ultramafics }\end{array}$ & $\begin{array}{l}\text { Serpentine } \\
\text { Siskiyous }\end{array}$ & $\begin{array}{l}\text { Western } \\
\text { Jurassic }\end{array}$ & $\begin{array}{c}\text { Siskiyou } \\
\text { Mountains }\end{array}$ & $\begin{array}{c}\text { Inland } \\
\text { Siskiyous }\end{array}$ & $\begin{array}{c}\text { Pelletreau } \\
\text { Ridge }\end{array}$ & $\begin{array}{l}\text { Rattlesnake } \\
\text { Creek }\end{array}$ & $\begin{array}{c}\text { Eastern } \\
\text { Klamath } \\
\text { Mountains }\end{array}$ & $\begin{array}{l}\text { Lower Soott } \\
\text { Mountains } \\
\end{array}$ & $\begin{array}{l}\text { Upper Scott } \\
\text { Mountains }\end{array}$ \\
\hline & & & & California & Oregon & & California & Oregon & & & & & \\
\hline $\begin{array}{l}\begin{array}{l}\text { Jefrrey Pine/Huckleberry Oak-Pinemat } \\
\text { Manzanita }\end{array} \\
\end{array}$ & & $x$ & & & & & & & & & & & \\
\hline $\begin{array}{l}\text { Jeffrey Pine/Huckleberry Oak-Pinemat } \\
\text { Manzanita-Bxx-leaved Silk Tassel }\end{array}$ & & $x$ & & & & & & & & & & & \\
\hline $\begin{array}{l}\text { Jeffrey Pine-Port-Orford-cedar/Huckleberry } \\
\text { Oak }\end{array}$ & & & & $x$ & & & $x$ & & & & & & \\
\hline $\begin{array}{l}\begin{array}{l}\text { Tanoak--Figleaf maple-Canyon Live Oak/ } \\
\text { Swordfern }\end{array} \\
\end{array}$ & & & & & & & & $x$ & & & & & \\
\hline $\begin{array}{l}\begin{array}{l}\text { Tanoak-Douglas-fir/Salal-Dwarf Oregon- } \\
\text { grape }\end{array} \\
\text { gat }\end{array}$ & & & & & & & & $x$ & & & & & \\
\hline $\begin{array}{l}\text { Tanoak-Douglas-fir/Salal-Evergreen } \\
\text { Huckleberry }\end{array}$ & & $x$ & & & $x$ & & & & & & & & \\
\hline $\begin{array}{l}\text { Tanoak-Douglas-fir/Salal-Pacific } \\
\text { Rhodddendron }\end{array}$ & & $x$ & & & & & & $x$ & & & & & \\
\hline $\begin{array}{l}\text { Tanoak-Douglas-fir-Cantyon Live Oak/Dwarf } \\
\text { Oregon-grape }\end{array}$ & & & & & $x$ & & & $x$ & & & & & \\
\hline $\begin{array}{l}\text { Tanoak-Douglas-fir-Canyon Live Oak/Poison } \\
\text { Oak }\end{array}$ & & & & & $x$ & & & & & & & & \\
\hline Tanoak-Golden Chinquapin/Salal-Sadler Oak & & & & & $x$ & & & $x$ & & & & & \\
\hline Tanoak-Golden Chinquapin-Sugar Pine & & & & & $x$ & & & $x$ & & & & & \\
\hline $\begin{array}{l}\text { Tanoak-Port-Orford-cedar/Dwarf Oregon- } \\
\text { grape/Twinflower }\end{array}$ & & & $x$ & $x$ & & $x$ & $x$ & & $x$ & & & & \\
\hline $\begin{array}{l}\begin{array}{l}\text { Tanoak-Port-Orford-cedar/Evergreen } \\
\text { fuckleberry }\end{array} \\
\end{array}$ & & & $x$ & $x$ & & $x$ & $x$ & & & $x$ & & & \\
\hline $\begin{array}{l}\begin{array}{l}\text { Tanoak-Port-Orford-cedar/Evergrzen } \\
\text { Huckleberry-Western Azalea }\end{array} \\
\end{array}$ & & & $x$ & $x$ & & $x$ & $x$ & & $x$ & & & & \\
\hline Tanoak-Port-Orford-cedar/Huckleberry Oak & & & $\mathrm{x}$ & $x$ & & $x$ & $\mathrm{x}$ & & & & & & \\
\hline $\begin{array}{l}\begin{array}{l}\text { Tanoak-Port-Orford-cedar/Pacific } \\
\text { Rhododendron }\end{array} \\
\end{array}$ & & & & & & $x$ & $x$ & & & & & & \\
\hline Tanoak-Port-Orford-cedar/Red Huckleberry & & & $\mathrm{x}$ & $x$ & & $x$ & $\mathrm{x}$ & & $\mathrm{x}$ & & & & \\
\hline Tanoak-Port-Orford-cedar/Salal & & $x$ & $\mathrm{x}$ & $x$ & $x$ & $\mathrm{x}$ & $x$ & $x$ & $\mathrm{x}$ & & & & \\
\hline Tancak-Port-Orford-cedar/Vine Maple & & & $x$ & $x$ & & $\mathrm{x}$ & $\mathrm{x}$ & & & & & & \\
\hline Tanoak-Port-Orford-cedar/Vine Maple//6-R & & & & & $x$ & & & & & & & & \\
\hline Tanoak-Port-Orford-cedar-Alder//Riparian & & & $\mathrm{x}$ & $x$ & & $\mathrm{x}$ & & & & & & & \\
\hline $\begin{array}{l}\text { Tanoak-Port-Orford-cedar-Califormia Bay/ } \\
\text { Evergreen Huckleberry }\end{array}$ & & & $x$ & $x$ & & $x$ & $x$ & & & & & & \\
\hline $\begin{array}{l}\text { Tanotk-Port-Orford-cedar-Red Alder// } \\
\text { Riparian }\end{array}$ & & & & & & & $x$ & & $x$ & $x$ & & & \\
\hline $\begin{array}{l}\text { Tanoak-Port-Orford-cedar-Redwood/ } \\
\text { Evergreen Huckleberry }\end{array}$ & & & & $x$ & & $x$ & & & & & & & \\
\hline
\end{tabular}




\begin{tabular}{|c|c|c|c|c|c|c|c|c|c|c|c|c|c|}
\hline & \multicolumn{13}{|c|}{ Ecoregion or Subsection } \\
\hline & $\begin{array}{c}\text { Mid-coastal } \\
\text { Sedimentary } \\
\text { and Southern } \\
\text { Oregon } \\
\text { Coastal } \\
\end{array}$ & $\begin{array}{c}\text { Coastal } \\
\text { Siskiyous }\end{array}$ & $\begin{array}{c}\text { Eastern } \\
\text { Franciscan } \\
\end{array}$ & $\begin{array}{c}\text { Gasquet } \\
\text { Mountain } \\
\text { Ultramafics } \\
\end{array}$ & $\begin{array}{l}\text { Serpentine } \\
\text { Siskiyous }\end{array}$ & $\begin{array}{l}\text { Western } \\
\text { Jurassic }\end{array}$ & $\begin{array}{l}\text { Siskiyou } \\
\text { Mountains }\end{array}$ & $\begin{array}{c}\text { Inland } \\
\text { Siskiyous }\end{array}$ & $\begin{array}{l}\text { Pelletreau } \\
\text { Ridge }\end{array}$ & $\begin{array}{c}\text { Rattlesnake } \\
\text { Creek }\end{array}$ & \begin{tabular}{c|} 
Eastern \\
Klamath \\
Mountains \\
\end{tabular} & $\begin{array}{c}\text { Lower Scott } \\
\text { Mountains }\end{array}$ & $\begin{array}{l}\text { Upper Soott } \\
\text { Mountains }\end{array}$ \\
\hline & & & & California & Oregon & & California & Oregon & & & & & \\
\hline $\begin{array}{l}\text { Tanoak-Port-Orford-cedar-Western Hemlock/ } \\
\text { Evergreen Huckleberry }\end{array}$ & & & $x$ & $x$ & & $x$ & & & & & & & \\
\hline $\begin{array}{l}\text { Tanoak-Western white pine/Huckleberry } \\
\text { aak/Beargrass }\end{array}$ & $x$ & $x$ & & & & & & & & & & & \\
\hline $\begin{array}{l}\text { Tanoak-Western Hemlock/Evergreen } \\
\text { Huckleberry/Swordfern }\end{array}$ & $x$ & & & & & & & & & & & & \\
\hline Western Hemlock-Tanoak-California Bay & $x$ & & & & & & & & & & & & \\
\hline $\begin{array}{l}\text { Western Hemlock/Evergreen Huckleberry/ } \\
\text { Swordfern }\end{array}$ & $x$ & & & & & & & & & & & & \\
\hline $\begin{array}{l}\text { Western Hemlock/Pacific Rhododendron- } \\
\text { Dwarf Oregon-grape }\end{array}$ & $x$ & & & & & & & $x$ & & & & & \\
\hline $\begin{array}{l}\text { Western Hemlock/Sadler Oak-Salal-Pacific } \\
\text { Rhododendron }\end{array}$ & & & & & $x$ & & & $x$ & & & & & \\
\hline Western Hemlock/Salal-Pacific Rhododendron & $x$ & & & & & & & $x$ & & & & & \\
\hline Western Hemlock/Swordfern & $x$ & & & & & & & & & & & & \\
\hline White Fir/Beargrass & & & & & $x$ & & & & & & & & \\
\hline White Fir/Dwarf Oregon-grape/Twinflower & & & & & & & & $x$ & & & & & \\
\hline White Fir/Dwarf Oregon-grape/Vanillateaf & & & & & & & & $x$ & & & & & \\
\hline White Fir/Huckleberry Oak & & & & & $x$ & & & $x$ & & & & & \\
\hline White Fir/Pacific Rhododendron-Sadler Oak & & & & & $\mathrm{x}$ & & & $x$ & & & & & \\
\hline White Fir/Pinemat Manzanita & & & & & $x$ & & & & & & & & \\
\hline $\begin{array}{l}\text { White Fir-Brewer Spruce/Common Prince's } \\
\text { Pine-Whitevein Pyrola }\end{array}$ & & & & & $\mathrm{x}$ & & & $x$ & & & & & \\
\hline White Fir-Douglas-fir/Baldhip Rose & & & & & & & & $x$ & & & & & \\
\hline White Fir-Douglas-fir/Poison Oak & & & & & & & & $x$ & & & & & \\
\hline White Fir-Tanoak/Common Prince's Pine & & & & & & & & $x$ & & & & & \\
\hline
\end{tabular}


A Range-Wide Assessment of Port-Orford-Cedar on Federal Lands 


\section{Unique Species and Regional Endemic, Rare or Sensitive Plants Found in Ecology Plots Used for Classification of Port-Orford-Cedar and Species Known to Occur with Port- Orford-Cedar Revised 5/13/20 by Lisa Hoover and Maria Ulloa}

\begin{tabular}{|c|c|}
\hline Scientific Name & Common Name \\
\hline Antennaria suffrutescens Greene & evergreen everlasting \\
\hline Arabis koelheri Howell var. stipitata Roll. & stipitate rock-cress \\
\hline Arabis macdonaldiana Eastwood & McDonald's rock-cress \\
\hline Arctostaphylos hispidula Howell & Howell's manzanita \\
\hline $\begin{array}{l}\text { Arctostaphylos klamathensis Edwards, Keeler-Wolf } \\
\text { \& Knight }\end{array}$ & Klamath manzanita \\
\hline Arnica cernua Howell & serpentine arnica \\
\hline $\begin{array}{l}\text { Cardamine nuttallii Greene var. gemmata Greene } \\
\text { Roll. (C. gemmata, D. gemmata) }\end{array}$ & yellow-tubered toothwort \\
\hline $\begin{array}{l}\text { Carex gigas (Holm) Mackenzie includes } \\
\text { C. scabriuscula Mack }\end{array}$ & Siskiyou sedge \\
\hline $\begin{array}{l}\text { Castilleja hispida Benth ssp. brevilobata (Piper) } \\
\text { Chuang \& Hechard }\end{array}$ & short-lobed Indian paintbrush \\
\hline $\begin{array}{l}\text { Castilleja miniata Hook ssp. elata (Piper) Munz } \\
\text { (Castilleja elata) }\end{array}$ & Siskiyou Indian paintbrush \\
\hline Chaenactis suffrutescens A. Gray & Shasta chaenactis \\
\hline Cypripedium californicum A. Gray & California lady's-slipper \\
\hline Cypripedium fasciculatum Kell. S. Watson & clustered lady's-slipper \\
\hline Cypripedium montanum Lindley & mountain lady's-slipper \\
\hline Darlingtonia californica Torrey & California pitcher plant \\
\hline $\begin{array}{l}\text { Dicentra formosa (Haw.) Walp. } \\
\text { ssp. oregana (Eastw.) Munz }\end{array}$ & Oregon bleeding heart \\
\hline Epilobium oreganum Greene & Oregon willow-herb \\
\hline $\begin{array}{l}\text { Erigeron cervinus Greene } \\
\text { (includes } E \text {. delicatus Cronq.) }\end{array}$ & Siskiyou daisy \\
\hline Eriogonum pendulum Wats. & Waldo buckwheat \\
\hline Eriogonum ternatum Howell & ternate buckwheat \\
\hline Eriogonum umbellatum Torrey var. humistratum Rev. & Mt. Eddy buckwheat \\
\hline Erythronium hendersonii S. Watson & Henderson's fawn lily \\
\hline Erythronium howellii Wats. & Howell's fawn lily \\
\hline Gentiana setigera (Gray) (G. bisetaea) & Waldo gentian \\
\hline $\begin{array}{l}\text { Hastingsia bracteosa S. Wats var. bracteosa } \\
\text { (Becking) Lang \& Zika } \\
\text { (H. bracteosa, Schoenolirion bracteosum) }\end{array}$ & largeflowered rushlily \\
\hline Horkelia sericata S. Watson & Howell's horkelia \\
\hline Iris innominata L. Henderson & Del Norte iris \\
\hline
\end{tabular}


Iris tenax Douglas ssp. klamathensis L. Lenz

Juncus dudleyi Wieg.

Lathyrus delnorticus C. Hitche.

Lewisia oppositifolia (Wats) Rob.

Lilium bolanderi $\mathrm{S}$. Watson

Lilium pardalinum Kellogg ssp. vollmeri (East.)

M. Skinner

Lilium pardalinum Kellogg ssp. wigginsii

(Beane \&Vollmer) M. Skinner

Lilium rubescens $\mathrm{S}$. Watson

Lilium washingtoniamum Kellogg ssp. purpurascens (Stearn)

M. Skinner

Lomatium howellii S. Watson

Penstemon filiformis (Keck) Keck

Phacelia dalesiana J. Howell

Pinguicula vulgaris ssp. macroceras (Link) Calder

\& R. Taylor

P. macroceras var. macroceras,

P. macroceras ssp. Nortensis

Pityopus californicus (Eastw.) H. Copel

Poa piperi A. Hitche.

Polystichum californicum (D. C. Eat) Diels

Potentilla cristae W. Ferlatte \& Strother

Pyrrocoma racemosa (Nutt.) Torrey \& A. Gray

var. congesta (Greene) G. Brown \& Keil

Raillardella pringlei Greene

Ribes marshallii Greene

Rubus nivalis Douglas

Salix delnortensis Schneid

Sanguisorba officinalis $\mathrm{L}$.

Sanicula peckiana J. F. Macbr.

Sedum laxum (Britton) A. Berger

ssp. flavidum Denton

Sedum laxum (Britton) A. Berger

ssp. Heckneri (M. Peck) R. T. Clausen

Smilax jamesii Wallace

Streptanthus howellii Wats

Tauschia glauca (J. Coulter \& Rose) Mathias

\& Constance

Triteleia crocea (Alph. Wood) Greene

var. modesta (H. M. Hall) Hoover

Vancouveria chrysantha Greene

Veratrum insolitum Jepson

Viola primulifolia L. var. occidentalis (Gray)

L. E. McKenney \& R. J. Little
Orleans iris

Dudley's rush

Del Norte pea

opposite-leaved lewisia

Bolander's lily

Vollmer's lily

Wiggin's lily

redwood lily

purple-flowered Washington lily

Howell's lomatium

thread-leaved beardtongue

Scott Mountain phacelia

Del Norte butterwort

California pinefoot

Piper's blue grass

California swordfern

crested potentilla

Del Norte pyrrocoma

showy raillardella

Marshall's gooseberry

snow dwarf bramble

Del Norte willow

great burnet

Peck's sanicle

pale yellow stonecrop

Heckner's stonecrop

English Peak Greenbriar

Howell's jewelflower

glaucous tauschia

Trinity Mountain triteleia

Siskiyou inside-out-flower

Siskiyou false-hellebore

western bog violet 


\section{Appendix D}

\section{Port-Orford-Cedar Short-term Raised Bed Common Garden Study Analysis of Variance Tables and Means}

\section{Table D.1-Analysis of variance (ANOVA) for height traits for watershed and breed zone} models

Values for height columns are probabilities of getting as high or higher F-values when Ho: is true.

\begin{tabular}{|c|c|c|c|c|}
\hline Source of Variation & $\begin{array}{c}\text { Degrees of } \\
\text { Freedom }\end{array}$ & $\begin{array}{r}\text { 2-Yr Total } \\
\text { Height }\end{array}$ & $\begin{array}{r}\text { 1-Yr Total } \\
\text { Height }\end{array}$ & $\begin{array}{r}2^{\text {nd }} \text { Yr Height } \\
\text { Growth }\end{array}$ \\
\hline Locations & 1 & .0010 & .0252 & .0005 \\
\hline Treatments & 1 & .6384 & .4016 & .0022 \\
\hline Loc* Trt & 1 & .0414 & .6468 & .0006 \\
\hline Blocks & 8 & .0001 & .0001 & .0001 \\
\hline \multicolumn{5}{|l|}{ Watershed Model: } \\
\hline Watersheds & 9 & .0001 & .0001 & .0001 \\
\hline Stands (wtrshd) & 42 & .0074 & .0112 & .0185 \\
\hline Families (stand) & 246 & .0001 & .0001 & .0001 \\
\hline Loc * Wtrshd & 9 & .0001 & .1758 & .0002 \\
\hline Loc*Stand & 42 & .9999 & .9999 & .4500 \\
\hline Loc * Fam (stand) & 246 & .0001 & .0052 & .0001 \\
\hline Trt * Wtrshd & 9 & .3470 & .4529 & .1291 \\
\hline Trt * Stand (wtrshd) & 42 & .2824 & .3001 & .0691 \\
\hline Trt * Fam (stand) & 246 & .9999 & .1041 & .9999 \\
\hline Loc * Trt * Wtrshd & 9 & .2013 & .0374 & .4884 \\
\hline Residual Mean Square & 2914 & 205.46 & 34.86 & 110.42 \\
\hline \multicolumn{5}{|l|}{ Breed Zone Model: } \\
\hline Breed Zones & 3 & .0001 & .0001 & .0001 \\
\hline Seed Zones (bz) & 6 & .0001 & .0001 & .0001 \\
\hline Families (sdz) & 288 & .0001 & .0001 & .0001 \\
\hline Loc *BZ & 3 & .0001 & .5465 & .0001 \\
\hline Loc* SdZ (bz) & 6 & .8447 & .2259 & .5505 \\
\hline Loc* Fam (sdz) & 288 & .0001 & .0060 & .0001 \\
\hline Trt* BZ & 3 & .0639 & .3957 & .0017 \\
\hline Trt * SdZ (bz) & 6 & .2274 & .4035 & .2289 \\
\hline Trt * Fam (sdz) & 288 & .9999 & .0586 & .9999 \\
\hline $\mathrm{Loc} * \operatorname{Trt} * \mathrm{Bz}$ & 3 & .4800 & .0565 & .5823 \\
\hline Residual Mean Square & 2961 & 206.53 & 34.92 & 111.17 \\
\hline
\end{tabular}


Table D.2-Least square means and standard errors main effects and some interactions for the watershed model for height (in centimeters) traits ${ }^{1}$

\begin{tabular}{|c|c|c|c|c|c|c|c|c|c|}
\hline Effect & Loc & Trt & Wtrshd & $\begin{array}{c}\text { LSMean } \\
\text { Ht2 }\end{array}$ & $\begin{array}{c}\text { Std Error } \\
\text { Ht2 }\end{array}$ & $\begin{array}{c}\text { LSMean } \\
\text { Ht1 }\end{array}$ & $\begin{array}{c}\text { Std Error } \\
\text { Ht1 }\end{array}$ & $\begin{array}{c}\text { LSMean } \\
\text { Ht2-1 }\end{array}$ & $\begin{array}{c}\text { Std Error } \\
\text { Ht2-1 }\end{array}$ \\
\hline Loc & Dor & & & 114.29 & 2.77 & 60.71 & 3.02 & 53.58 & 1.08 \\
\hline Loc & Hum & & & 94.52 & 2.77 & 49.02 & 3.02 & 45.50 & 1.08 \\
\hline Trt & & Sha & & 103.39 & 2.77 & 56.81 & 3.02 & 46.57 & 1.07 \\
\hline Trt & & Sun & & 105.42 & 2.77 & 52.92 & 3.02 & 52.51 & 1.07 \\
\hline Loc ${ }^{*}$ Trt & Dor & Sha & & 108.87 & 3.80 & 61.61 & 4.25 & 47.25 & 1.42 \\
\hline Loc"Trt & Dor & Sun & & 119.72 & 3.80 & 59.81 & 4.25 & 59.91 & 1.42 \\
\hline Loc ${ }^{*}$ Trt & Hum & Sha & & 97.92 & 3.80 & 52.02 & 4.25 & 45.89 & 1.42 \\
\hline Loc ${ }^{*}$ Trt & Hum & Sun & & 91.12 & 3.80 & 46.02 & 4.25 & 45.10 & 1.42 \\
\hline Wtrshd & & & App & 103.40 & 3.27 & 54.31 & 2.46 & 49.11 & 1.71 \\
\hline Wtrshd & & & $\mathrm{Coq}$ & 115.97 & 2.31 & 59.34 & 2.21 & 56.62 & 1.04 \\
\hline Wtrshd & & & Dun & 124.52 & 3.32 & 63.54 & 2.47 & 60.96 & 1.75 \\
\hline Wtrshd & & & Ilv & 101.75 & 4.41 & 53.15 & 2.82 & 48.63 & 2.44 \\
\hline Wtrshd & & & $\mathrm{Kla}$ & 99.25 & 3.61 & 52.88 & 2.56 & 46.37 & 1.93 \\
\hline Wtrshd & & & Rog & 105.80 & 3.03 & 55.41 & 2.40 & 50.37 & 1.56 \\
\hline Wtrshd & & & Sac & 85.88 & 3.48 & 48.48 & 2.51 & 37.39 & 1.84 \\
\hline Wtrshd & & & Six & 127.46 & 4.42 & 64.67 & 2.82 & 62.82 & 2.45 \\
\hline Wtrshd & & & $\mathrm{Smh}$ & 100.66 & 2.80 & 53.17 & 2.33 & 47.43 & 1.40 \\
\hline Wtrshd & & & Trn & 79.38 & 4.59 & 43.70 & 2.89 & 35.71 & 2.56 \\
\hline
\end{tabular}

${ }^{1} \mathrm{HT} 1=$ first year total height; HT2 = second year total height; HG2-1 = second year height growth increment; traits are averages across both sites. 
Table D.3-Least square means and standard errors main effects and some interactions for the breed zone model for height (in centimeters) traits ${ }^{1}$

\begin{tabular}{|c|c|c|c|c|c|c|c|c|c|c|}
\hline Effect & Loc & Trt & $\mathrm{BZ}$ & $\mathrm{SdZ}$ & $\begin{array}{c}\text { LSMean } \\
\text { H七2 }\end{array}$ & $\begin{array}{c}\text { Std Error } \\
\text { Ht2 }\end{array}$ & $\begin{array}{c}\text { LSMean } \\
\text { Ht1 }\end{array}$ & $\begin{array}{c}\text { Std Error } \\
\text { Ht1 }\end{array}$ & $\begin{array}{c}\text { LSMean } \\
\text { Ht2-1 }\end{array}$ & $\begin{array}{c}\text { Std Error } \\
\text { Ht2-1 }\end{array}$ \\
\hline Loc & Dor & & & & 109.86 & 2.69 & 59.08 & 3.00 & 50.79 & 1.01 \\
\hline Loc & Hum & & & & 91.67 & 2.69 & 47.48 & 3.00 & 44.19 & 1.01 \\
\hline Trt & & Sha & & & 99.91 & 2.68 & 55.15 & 3.00 & 44.76 & 0.98 \\
\hline Trt & & Sun & & & 101.62 & 2.68 & 51.41 & 3.00 & 50.21 & 0.98 \\
\hline Loc ${ }^{x} T r t$ & Dor & Sha & & & 104.60 & 3.74 & 59.95 & 4.24 & 44.64 & 1.36 \\
\hline Loc*Trt & Dor & Sun & & & 115.13 & 3.74 & 58.21 & 4.24 & 56.93 & 1.36 \\
\hline Loc*Trt & Hum & Sha & & & 95.23 & 3.74 & 50.36 & 4.24 & 44.87 & 1.36 \\
\hline Loc ${ }^{*}$ Trt & Hum & Sun & & & 88.11 & 3.74 & 44.61 & 4.24 & 43.50 & 1.36 \\
\hline $\mathrm{BZ}$ & & & $\mathrm{NC}$ & & 115.97 & 2.03 & 59.61 & 2.15 & 56.36 & 0.81 \\
\hline$B Z$ & & & NI & & 102.25 & 2.19 & 53.69 & 2.19 & 48.55 & 0.95 \\
\hline$B Z$ & & & SC & & 101.90 & 2.41 & 53.62 & 2.25 & 48.28 & 1.12 \\
\hline BZ & & & SI & & 82.96 & 2.53 & 46.20 & 2.28 & 36.76 & 1.21 \\
\hline $\mathrm{SdZ}(\mathrm{BZ})$ & & & $\mathrm{NC}$ & 071 & 124.38 & 2.57 & 63.31 & 2.29 & 61.08 & 1.24 \\
\hline $\mathrm{SdZ}(\mathrm{BZ})$ & & & $\mathrm{NC}$ & 072 & 118.15 & 2.04 & 60.33 & 2.16 & 57.82 & 0.82 \\
\hline $\mathrm{SdZ}(\mathrm{BZ})$ & & & $\mathrm{NC}$ & 081 & 105.36 & 2.53 & 55.18 & 2.28 & 50.18 & 1.20 \\
\hline $\mathrm{SdZ}(\mathrm{BZ})$ & & & $\mathrm{NI}$ & 511 & 104.07 & 2.51 & 54.58 & 2.27 & 49.49 & 1.19 \\
\hline $\mathrm{SdZ}(\mathrm{BZ})$ & & & NI & 512 & 100.42 & 2.53 & 52.81 & 2.28 & 47.61 & 1.20 \\
\hline $\mathrm{SdZ}(\mathrm{BZ})$ & & & SC & 091 & 105.59 & 3.24 & 55.02 & 2.48 & 50.57 & 1.70 \\
\hline $\mathrm{SdZ}(\mathrm{BZ})$ & & & $\mathrm{SC}$ & 301 & 95.42 & 2.53 & 51.65 & 2.28 & 43.75 & 1.20 \\
\hline $\mathrm{SdZ}(\mathrm{BZ})$ & & & SC & 302 & 104.70 & 3.96 & 54.19 & 2.72 & 50.51 & 2.16 \\
\hline $\mathrm{SdZ}(\mathrm{BZ})$ & & & SI & 331 & 80.03 & 3.60 & 43.90 & 2.60 & 36.13 & 1.93 \\
\hline $\mathrm{SdZ}(\mathrm{BZ})$ & & & SI & 521 & 85.88 & 2.49 & 48.49 & 2.27 & 37.38 & 1.17 \\
\hline Loc $^{*} B Z$ & Dor & & $\mathrm{NC}$ & & 127.35 & 2.77 & 65.43 & 3.02 & 61.92 & 1.09 \\
\hline $\operatorname{Loc}^{*} \mathrm{BZ}$ & Dor & & NI & & 112.53 & 2.94 & 59.82 & 3.05 & 52.71 & 1.26 \\
\hline $\operatorname{Loc}^{*} B Z$ & Dor & & SC & & 110.08 & 3.16 & 59.19 & 3.10 & 50.88 & 1.46 \\
\hline $\operatorname{Loc}^{*} \mathrm{BZ}$ & Dor & & SI & & 89.49 & 3.29 & 51.86 & 3.13 & 37.63 & 1.57 \\
\hline Loc $* B Z$ & Hum & & $\mathrm{NC}$ & & 104.58 & 2.77 & 53.78 & 3.02 & 50.80 & 1.09 \\
\hline Loc $* B Z$ & Hum & & NI & & 91.96 & 2.94 & 47.57 & 3.05 & 44.39 & 1.26 \\
\hline Loc*BZ & Hum & & SC & & 93.72 & 3.16 & 48.05 & 3.10 & 45.68 & 1.46 \\
\hline Loc*BZ & Hum & & SI & & 76.42 & 3.29 & 40.53 & 3.13 & 35.88 & 1.57 \\
\hline Trt*BZ & & Sha & $\mathrm{NC}$ & & 114.46 & 2.75 & 61.73 & 3.02 & 52.73 & 1.05 \\
\hline $\operatorname{Tr} t^{*} B Z$ & & Sha & NI & & 101.32 & 2.90 & 55.70 & 3.05 & 45.62 & 1.20 \\
\hline $\mathrm{Trt}^{*} \mathrm{BZ}$ & & Sha & $\mathrm{SC}$ & & 100.18 & 2.10 & 55.14 & 3.10 & 45.04 & 1.37 \\
\hline $\operatorname{Trt}^{*} \mathrm{BZ}$ & & Sha & SI & & 83.69 & 3.22 & 48.04 & 3.12 & 35.64 & 1.47 \\
\hline $\operatorname{Trt} * B Z$ & & Sun & $\mathrm{NC}$ & & 117.47 & 2.75 & 57.48 & 3.02 & 59.98 & 1.05 \\
\hline $\operatorname{Tr} t^{*} B Z$ & & Sun & $\mathrm{NI}$ & & 103.17 & 2.90 & 51.69 & 3.05 & 51.48 & 1.20 \\
\hline $\operatorname{Tr} t^{*} B Z$ & & Sun & SC & & 103.62 & 3.10 & 52.11 & 3.10 & 51.52 & 1.37 \\
\hline $\operatorname{Tr} t^{*} B Z$ & & Sun & SI & & 82.23 & 3.22 & 44.35 & 3.12 & 37.88 & 1.47 \\
\hline
\end{tabular}


A Range-Wide Assessment of Port-Orford-Cedar on Federal Lands

Table D.4-Distribution of variance components (\%) for height traits using the watershed model

Varcomp Trait Watershed Stand/W Family/S Loc $x W$ Loc $x S$ Loc $x F$ Block Error

$\begin{array}{lrlllllll}1^{\text {st }} \text { Yr Ht } & 26.5^{* *} & 2.8^{* *} & 9.1^{* *} & 0.1 & 0.0 & 1.2^{* *} & 35.0^{* *} & 25.4 \\ \mathrm{HG} 2^{\text {nd }} \mathrm{Yr} & 28.0^{* *} & 2.6^{* *} & 2.8^{* *} & 3.6^{* *} & 0.1 & 6.7^{* *} & 11.2^{* *} & 45.0 \\ 2^{\text {nd }} \text { Yr Ht } & 37.4^{* *} & 3.4^{* *} & 6.7^{* *} & 1.6^{* *} & 0.0 & 4.5^{* *} & 9.9^{* *} & 36.5 \\ & & & & & & & & \end{array}$

Table D.5-Distribution of variance components (\%) for height traits using the breed zone model

$\begin{array}{lllllll}\text { Barcomp Trait } & \text { Breed } & \text { Seed } & \text { Zone Zone/BZ }\end{array}$ Family/SZ Loc $x B Z$ Loc $x S Z$ Loc $x F$ Block Error

\begin{tabular}{|c|c|c|c|c|c|c|c|c|c|}
\hline $1^{\text {st }} \mathrm{Yr} \mathrm{Ht}_{\mathrm{r}}$ & & $18.6^{* *}$ & $5.6^{* *}$ & $12.5^{k-k}$ & 0.0 & 0.1 & $1.2^{* * *}$ & $36.0^{k \hbar k}$ & 26.0 \\
\hline $\mathrm{HG} 2^{\text {nd }} \mathrm{Yr}$ & & $21.8^{\star \star \hbar}$ & $6.1^{\text {*** }}$ & $4.9^{* * *}$ & $3.2^{\text {** }}$ & 0.0 & $7.1^{* *}$ & $11.4^{* *}$ & 45.5 \\
\hline $2^{\text {nd }} \mathrm{Yr} \mathrm{Ht}$ & & $28.1^{* * *}$ & $7.7^{* *}$ & $10.2^{\star \star}$ & $1.8^{* *}$ & 0.0 & $4.6^{* * *}$ & $10.2^{* *}$ & 37.4 \\
\hline
\end{tabular}

*** $=$ significant at $\mathrm{p}<0.01$. 


\section{Appendix E}

\section{Details of Resistance Screening Process}

The initial screening of 193 parent trees from the Siskiyou and Six Rivers National Forests utilized the wound inoculation technique. The parent trees tested were selected from areas where other Port-Orford-cedar had died, likely from Phytophthora lateralis. The range of lesion lengths varied widely among these selected trees, with some trees having small lesion scores comparable to the best trees previously tested, while other trees appeared to have little resistance based upon this technique. Since this was early in the testing process, rooted cuttings from over half of the selections were kept and placed into a breeding or preservation orchard.

Ten branch tips were collected from each of 190 candidate trees from five sites on the Bureau of Land Management Medford District. Most of the candidate trees were from forest areas with established $P$. lateralis infections. Branches for the five sites were screened at different time periods in the summer of 1995. Large differences were observed for lesion length among the 190 candidate trees, with some trees showing resistance comparable to the resistant checklot (PO-OSU-CF1), and others being no better than a low resistance checklot (OSU-HH). The highest-ranking parent trees (generally those comparable to PO-OSU-CF1 and/or with a lesion length less than $20 \mathrm{~mm}$ ) were selected for placement into a breeding orchard.

In 1996, seedling offspring from 344 parents (and two bulk seedlots) selected for a common garden study (see Chapter 5) were screened for resistance. Each family was evaluated using two screening techniques: a stem dip method and a root dip method. Different seedlings from each family were used for the two inoculation methods; in general, 15 seedlings per family were inoculated. Families screened in 1996 represented random selections, and were generally not selected with disease resistance in mind.

Significant variation among families was found in the 1996 range-wide screening for both tests. Individual tree heritabilities $\left(\mathrm{h}_{\mathrm{i}}{ }^{2}\right)$ were very high using the root dip technique and fairly low using the stem dip technique. In addition, a low correlation between the two inoculation methods was noted. However, the frequencies of these types of resistance appear to be low in natural populations. Since the stem dip test allows for a more rapid assessment, it has been used for the initial phase of operational screening since 1997 with the contingency that the root dip test and/or field plantings will be used for selection validation and possible identification of other types of resistance. Two or three seedlings from 148 families representing the top 90 families from the stem dip test and top 90 families from the root dip test (an overlap did occur) were selected for placement into a breeding orchard.

Since 1997, more than 9,000 field selections have been screened using the stem dip technique. Approximately 10 percent of the candidates are being selected for placement into a breeding orchard. Results from the 1997 and 1998 screening showed that the high resistant checklot, PO-OSU-CF1, had a smaller lesion length (often considerably smaller) than the mean of the clones in each run for 70 of the 71 runs, the only exception being in Run 5 in 1998 where PO-OSU-CF1 had an abnormally high lesion length.

The lesion length of the best candidate tree in each run was often similar, or slightly less than for PO-OSU-CF1. In these runs, lesion length for the low resistant checklot, PO-OSU-CON1, was usually much larger than for the run mean, but often was less than the candidate tree with the largest lesion length. Within a run, there was generally 
wide variation in branch lesion means among the clones in 1997 and 1998, with some outstanding clones for both high and low lesion length. From examination of the data collected in 1997 and 1998, no obvious geographic trend is notable for relative branch lesion length. 


\section{Appendix F}

\section{Field Validation Plantings of Potentially Resistant Port-Orford-Cedar}

In 1993, two sites on the Siskiyou National Forest, known to have Phytophthora lateralis, were planted with one-year-old Port-Orford-cedar seedlings (Quosatana on the Gold Beach Ranger District and Flannigan on the Powers Ranger District). Twenty-eight seedling families (whose parents were screened in 1989/90), representing a range of resistance, were planted. Individual replications at each site encircled previously dead Port-Orford-cedar. Assessment of these plantings involves recording the presence of trees dead from $P$. lateralis. Survival in 1999 was 13 percent at Quosatana and 23 percent at Flannigan. Comparison of family means at the two sites showed some parents, such as 510015, with relatively good survival at both sites (31 percent at Quosatana, 53 percent at Flannigan), but some inconsistencies among other parents. Fifty percent of the mortality at the sites occurred within one year of out-planting, indicating that rapid field assessment of resistance may be possible. Variation in mortality among replications at a site indicates that microsite may play an important role. A remaining question that this early planting will help elucidate is how long will the best families from natural stands continue to show survival, and what percentage of the trees in these families survives.

Because Quosatana, on the Gold Beach Ranger District, was known to be a high hazard site for $P$. lateralis, a second validation planting was installed in 1996. This planting included a subset of the families screened at OSU in 1996. However, almost all of these seedlings died within a few months of planting. High early mortality was possibly due to a combination of factors including seedling stress and P. lateralis infection (a small sample of trees was evaluated by Dr. Everett Hansen at OSU and a high proportion of the trees were infected). Physiological stress was noted as evidenced by foliage scorching, sunburn or freeze-drying. Symptoms were most severe on the top side of the foliage. ${ }^{27}$ No further assessments of the planting have been made, although observations at the site made while assessing other plantings have indicated that a proportion of the resistant checklots are still alive.

In 1998, 107 seedling families were planted at three sites: (1) Quosatana on the Gold Beach Ranger District, Siskiyou National Forest, (2) Camas Valley on the Bureau of Land Management (BLM) Roseburg District, and (3) the raised beds at Oregon State University. Two major categories of families were utilized in these plantings: (1) approximately 95 families that were screened in 1996 which were a subset of the families used in the common garden study and (2) families from control pollinations and open pollinated seed involving some of the more resistant parents tested. Examination of survival data indicates that, in general, there is not a strong correlation in family performance between the sites. Two methods of assessment were utilized for these three plantings and this may be one of the principal factors in the lower than expected correlation between family means. Depending upon the site, seedlings in some or all of the replications were pulled to examine disease progression. On the remaining replicates the seedlings were left and mortality was recorded. In general, it appears that the seedlings pulled for evaluation at the three sites, were pulled at relatively light (Quosatana), moderate (Camas Valley) and very heavy (OSU) levels of infestation. Several common families were highly ranked at all three sites, notably in the control pollination families. However, infestation levels at the OSU site were so high that few families stood out, while the infestation levels at the

\footnotetext{
${ }^{27}$ Hansen, E.M. 1996. Personal communication. Professor of Forest Pathology, Oregon State University, Department of Botany and Plant
} 
time of examining roots at Quosatana may have been too low to allow full discrimination between families. Unknown at this time are how many (and which) resistance mechanisms may be present, and whether a variation in screening method or assessment method is needed to include families with different resistance mechanisms.

The Camas Valley site and the raised beds at OSU were utilized again in 1999 as planting sites. Two types of material were utilized in the plantings: (1) 29 seedling families from control pollinations and open pollinated seed involving some of the more resistant parents tested and (2) rooted cuttings of a number of parents selected from the 1997 operational screenings ( 20 clones for Camas Valley and 165 clones at OSU). Similar to the results from the 1998 planting, the survival data indicates that there is not a strong correlation in family performance between the sites. The level of infection and mortality at Camas Valley was much lower than that at OSU and probably too low to be able to distinguish family differences. However, significant differences between family means were detected for percent mortality at OSU. In addition, three small demonstration plantings, comparing rooted cuttings of the high resistant checklot PO-OSU-CFI to more susceptible seedlings and cuttings were established. The plantings will help validate some previous screening results and may provide some long-term evaluation of resistance.

Four sites were planted in 2000. The Camas Valley site and the OSU raised beds were planted again as well as new sites on the BLM Medford District (Bill Creek) and a site on private land in Hiouchi, California. As in 1999, two types of material were utilized in the plantings: (1) 108 seedling families from control pollinations and open pollinated seed involving some of the more resistant parents tested and (2) 128 rooted cuttings of a number of parents selected from the 1997 and 1998 operational screenings. Preliminary results indicate very strong differences among both seedling families and parents tested via rooted cuttings. Preliminary results from the root dip screening of the top ranking candidates from stem dip screening indicate that a moderate percentage of the initial selections may have resistance comparable to the high-resistant checklots. 


\section{Appendix G}

\section{Development of the Interagency Port- Orford-Cedar Root Disease Management Coordination Effort: A Brief History}

Although individual National Forests and Ranger Districts had been instituting PortOrford-cedar root disease management activities in their own areas for some years, there was no attempt to develop a coordinated effort for federal lands prior to the mid-1980s. In October 1985, the Western Natural Resources Law Clinic, representing the Northcoast Environmental Center, the Oregon Natural Resources Council, and the Oregon Native Plant Society expressed concern that the Forest Service was not protecting Port-Orfordcedar from root disease. The groups requested the establishment of an inter-regional committee, composed of Forest Service and citizen members, with authority to formulate binding Port-Orford-cedar root disease policy. In response to this request, the Forest Service met with the Western Natural Resources Law Clinic on January 21, 1986 to discuss their concerns about management of Port-Orford-cedar and its root disease. Following this meeting, the Western Natural Resources Law Clinic formed a Citizens' Panel in February 1986. The stated purposes of the Citizens' Panel were to develop recommendations for management standards and guidelines designed to protect PortOrford-cedar from the spread of root disease, to preserve Port-Orford-cedar in its natural diversity throughout its native range, and to reestablish the commercial viability of the species.

In May 1987, an inter-regional Port-Orford-cedar Coordinating Group was formed by the Forest Service and Bureau of Land Management (BLM). The Coordinating Group was composed of a line officer, pathologists, ecologists, geneticists, representatives from the national forests with Port-Orford-cedar, and a representative of the BLM. The purpose of the group was to coordinate all activities affecting Port-Orford-cedar within and between Forest Service Regions 5 and 6 and the BLM. The Coordinating Group was charged with developing an action plan directed at the issues of highest concern (inventory, research needs, management, and public education). The Port-Orford-Cedar Action Plan was completed in 1988 .

The Port-Orford-cedar program manager, an inter-regional Forest Service position, was added in 1989 to oversee the activities of the Port-Orford-cedar coordinating group. This full-time position was established to serve as a vital link in coordinating and completing the tasks listed in the Action Plan and to provide a lead person for evaluation and transfer of new technology as research findings become available for management of Port-Orford-cedar and its root disease.

In October 1994, the BLM issued the Port-Orford-Cedar Management Guidelines. The Guidelines contained management objectives, implementation strategies, measures for timber sale and service contracts to minimize spread of the pathogen, and specifications for equipment washing and cleaning. The intent of the Guidelines is to assist in retaining Port-Orford-cedar as a viable part of the forest ecosystem and to reduce the occurrence of the root disease. The BLM Guidelines recommended administrative procedures and best management practices, to be considered on a site-specific basis and analyzed in National Environmental Protection Act (NEPA) documents. In August, 1995, the BLM created and also filled a full-time Port-Orford-cedar Coordinator position. 
From 1993 to 1998 , several lawsuits were pursued by various environmental organizations, heightening the level of awareness of the Port-Orford-cedar issue within and outside of the federal agencies.

Environmental groups filed an action in January 1995 in the District Court in Northern California seeking declaratory and injunctive relief under NEPA and the National Forest Management Act against the Forest Service's Port-Orford-Cedar Action Plan and the BLM's Port-Orford-Cedar Management Guidelines. They sought an order enjoining the Forest Service and the BLM "to prepare a comprehensive, inter-regional environmental impact statement (EIS) on their management of the Port-Orford-cedar and its habitat" and, in the meantime, "to undertake all necessary actions to prevent the spread or introduction of Phytophthora lateralis and to maintain healthy diverse Port-Orford-cedar stands and habitat."

The U.S. District Court issued a decision in August 1996 agreeing with the government's argument that the plaintiffs cannot challenge under the Administrative Procedures Act (APA) government "programs" in general. The court found that the alleged "PortOrford-cedar Program" was a term loosely applied to all the actions that the government took regarding managing Port-Orford-cedar including public education efforts, research, and sharing databases. Such a general program was not a "final agency action" reviewable under the APA.

As to the challenges to specific decisions such as the adoption of the BLM's Port-OrfordCedar Management Guidelines in the BLM's Resource Management Plan decisions, the court found that the Guidelines merely contained possible control strategies for root diseases that managers may or may not select in subsequent site-specific NEPA decision processes.

The court concluded that since the Guidelines did not require land managing agency managers to take any action or make any specific proposal or commit any resources, it was reasonable for the government to determine that the Guidelines did not constitute a major federal action significantly affecting the quality of the human environment. The Ninth Circuit Court of Appeals affirmed this decision on appeal.

However, in Kern v. Bureau of Land Management, plaintiffs challenged an action which used the Guidelines, alleging that BLM failed to consider the impacts of the spread of $P$. lateralis in the Resource Management Plan ElS or in the Sandy-Remote Analysis Area Environmental Assessment. The plaintiffs also complained that the BLM failed to monitor and inventory the root rot disease or to control adverse effects posed by off-highway vehicle use. The U.S. District court of Oregon ruled that the BLM had adequately inventoried and analyzed the impacts on Port-Orford-cedar in the geographic area affected by the proposed project. In 2002, the Ninth Circuit reversed the lower court and ruled that when the programmatic ElS to which a project is tiered does not contain an adequate analysis of cumulative impacts of the adoption of the Guidelines in the programmatic decision, the tiering EA will also be inadequate if it does not include a cumulative impact analysis which would be sufficient for the programmatic level, even if the site specific analysis may have been sufficient for the particular watershed where the proposed action was located. As a result of this decision, the BLM and Forest Service administrative units in southwestern Oregon are preparing a supplemental environmental impact statement on the effects on the Port-Orford-cedar species from the management of the federal forests under the Northwest Forest Plan.

The Forest Service reviewed accomplishment of the tasks within the Action Plan in April 1995. The review determined that the majority of the items on the Action Plan had been accomplished or concluded and that ongoing items, such as monitoring, had been incorporated into individual forest plan management direction and forest-wide standards and guidelines. Based on these findings, the Forest Service found that the Action Plan 
had been completed and could be concluded. The Regional Foresters accepted the recommendation and the Action Plan ceased to be operative May 16, 1995.

The Coordinating Group continues to function as a clearinghouse of information, to transfer technologies, and to coordinate range-wide activities dealing with Port-Orfordcedar. Two federal agency coordinators are responsible for disseminating information, coordinating activities to insure that protective measures are understood and used, educating the public on issues surrounding Port-Orford-cedar, and pursuing measures that will protect this species in its natural habitat. 
A Range-Wide Assessment of Port-Orford-Cedar on Federal Lands 


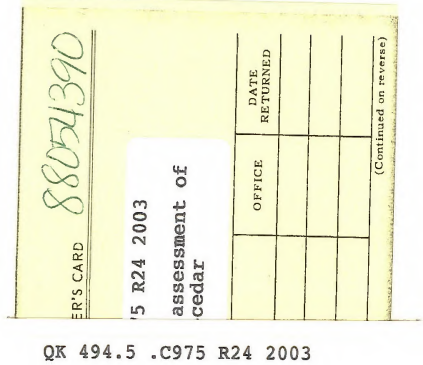

A range-wide assessment of Port-Orford-cedar

\author{
BLM LIERAAY \\ BLDG 50, ST-150A \\ DENVEA FEDERAL CENTEA \\ P.O. BOX 25047 \\ DENVER, COLORADO 80225
}




\section{A Range-Wide Assessment of \\ Port-Orford-Cedar \\ (Chamaecyparis larwsoniana) \\ on Federal Lands}
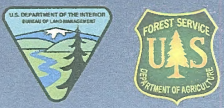

\section{Bureau of Land Management}

Oregon State Office

333 S.W. First Avenue

Portland, Oregon 97204

\section{USDA Forest Service}

Pacific Northwest Region

333 5.W. First Avenue

Portland, Oregon 97204

USDA Forest Service

Pacific Southwest Region

1323 Club Drive

Vallejo, California 94592 